\title{
A consistência da interface com o usuário para a TV interativa
}

Dissertação de Mestrado apresentada à Escola Politécnica da Universidade de São Paulo para obtenção do título de Mestre em Engenharia.

Área de Concentração:

Sistemas Eletrônicos

Candidato:

Gil Garcia de Barros

Orientador:

Prof. Dr. Marcelo Knörich Zuffo

São Paulo

Setembro de 2006 


\section{FICHA CATALOGRÁFICA}

\section{Barros, Gil Garcia de}

A consistência da interface com o usuário para a TV interativa / G.G. de Barros. --

São Paulo, 2006.

p. 200

Dissertação (Mestrado) - Escola Politécnica da Universidade de São Paulo. Departamento de Engenharia de Sistemas Eletrônicos.

1.Interface homem-computador 2.Televisão interativa 3.Multimídia interativa I.Universidade de São Paulo. Escola Politécnica. Departamento de Engenharia de Sistemas Eletrônicos II.t. 
À minha família, aos meus amigos, aos meus professores. Aos usuários. 


\section{Agradecimentos}

Ao Prof. Dr. Marcelo Knörich Zuffo, pela orientação e ensinamentos sobre a ciência.

Ao colega Richard Faust, pelo apoio na elaboração deste trabalho e pelos debates sobre usabilidade e TV interativa.

À toda a equipe que ajudou a construir o Laboratório de TV Digital do LSI-USP, em especial aos colegas e amigos Domingos, Laisa e Rogério.

Aos pesquisadores dos diversos grupos do LSI-USP, em especial à colega Julia. Aos pesquisadores envolvidos no SBTVD, em especial ao grupo de trabalho de usabilidade e ao colega Valdecir.

A todos os usuários e seus familiares que dispuseram de seu tempo livre para participar desta pesquisa.

À minha família e amigos, pelo incentivo e pelo afeto. 


\section{Resumo}

Nos últimos anos observa-se um intenso debate acerca da transição da TV analógica para a TV digital, acompanhada pela incorporação de inúmeras inovações, dentre as quais destacamos a interatividade, que abre uma nova modalidade para este meio de comunicação, a TV interativa. Os desafios de pesquisa e desenvolvimento em TV interativa são amplos e ainda não totalmente investigados. Em particular, a questão da consistência de interfaces com usuário se apresenta como um tópico relevante e pouco explorado na literatura. Esta dissertação investiga a questão da consistência da interface com o usuário para a TV interativa, considerando seus aspectos teóricos e de implementação. Para tanto investigamos na literatura de Interfaces Humano-Computador a questão da consistência e suas abordagens. Considerando que a consistência é uma característica relativa a um modelo, buscamos identificar modelos de interfaces de TV interativa que sejam exemplos de boas práticas a serem seguidas. A metodologia proposta e utilizada é composta por cinco etapas, a saber: modelagem do usuário, análise de tarefas, diretrizes gerais de interface, análise comparativa de plataformas e coordenação da interface. As três primeiras etapas geram recomendações enquanto que a etapa de análise comparativa gera referências. Utilizando estes dois subsídios a etapa de coordenação da interface objetiva elencar exemplos de interfaces que possam se tornar modelos, esta etapa também verifica a consistência interna do modelo proposto e elabora alternativas no caso das soluções encontradas não serem satisfatórias. No âmbito desta metodologia realizamos extensas avaliações experimentais, dentre as quais destacamos a proposta de quatro modelos de usuário (Torcedor Antenado, Mãe Ocupada, Meia Idade com Ajuda e Torcedor com Baixa Alfabetização), uma análise contextual de tarefas envolvendo dois dos quatro modelos de usuário propostos, bem como uma extensa análise comparativa entre sete plataformas de TV. Este trabalho resultou numa proposta integrada de interface que abrange três aspectos: um mapa de navegação, um conjunto mínimo de teclas para o controle remoto e um modelo de navegação. $\mathrm{O}$ mapa de navegação apresenta a taxonomia do sistema. O conjunto mínimo de teclas compreende os recursos mínimos que devem estar universalmente disponíveis ao usuário. O modelo de navegação apresenta uma forma consistente e extensível de navegação para ser utilizada em aplicativos de TV interativa. 


\begin{abstract}
In the past few years there has been an intense debate about the transition from analog to digital Television, with the acquisition of many innovations. Of particular interest to this study is the interactivity, which opens a new modality for this medium, the interactive TV. The challenges posed by research and development in interactive TV are ample and not fully investigated. In particular, the question of user interface consistency presents itself as a relevant topic, which is little explored in the literature. This work investigates the question of user interface consistency for interactive TV, taking into account it's theoretical and implementation implications. The question of consistency and its approaches was reviewed in the literature of HumanComputer Interfaces. Considering that consistency is a characteristic relative to a model, we tried to identify models of interactive TV interfaces, which are examples of best practices to be followed. The methodology proposed and utilized has five steps: user modeling, task analysis, interface guidelines, platform comparative analysis and interface coordination. The first three steps generate recommendations while the comparative analysis generates references. Using these two products the interface coordination tries to determine examples of interfaces, which can become models, this step also verifies the internal consistency of the proposed model and elaborates alternatives if the found solutions are not satisfactory. Using this methodology a large experimental evaluation was performed. Of special interest is the proposition of four user models, a contextual task analysis of two of the user models as well as an extensive comparative analysis between seven TV platforms. The result of this work is the proposition of an integrated interface, which focuses on three aspects: the navigation map, the minimum remote and a navigation model. The navigation map is the taxonomy of the system. The minimum remote is a group of keys that should be universally available to the user. The navigation model presents a consistent and extensible mechanism for navigation in interactive TV applications.
\end{abstract}




\section{Lista de Figuras}

Figura 1-1 - Diagrama resumido da metodologia adotada .6

Figura 1-2 - Diagrama da estrutura da dissertação .8

Figura 2-1 - Exemplo de interface em português 11

Figura 2-2 - Exemplo da mesma interface em outra língua..... 11

Figura 2-3 - Crianças desenhando na folha de plástico colocada sobre a tela de TV

(THOMASSON, 2003) 16

Figura 2-4 - Exemplo de TVe com tarja sobre vídeo (BROADBAND, 2006)...... 19

Figura 2-5 - Exemplo de TVe com vídeo redimensionado (BROADBAND, 2006)......19

Figura 2-6 - Exemplo de aplicativo de TV ativa para envio de SMS (BROADBAND, 2006) 20

Figura 2-7 - Exemplo de aplicativo de TV ativa com previsão do tempo

(BROADBAND, 2006). 20

Figura 2-8 - Exemplo de guia de programação (BROADBAND, 2006) 20

Figura 2-9 - Exemplo de menu de navegação (BROADBAND, 2006) 20

Figura 2-10 - Interface de programa do canal SKY News (BROADBAND, 2006) ........23

Figura 2-11 - Interface de outro programa do canal SKY News (BROADBAND, 2006)

Figura 2-12 - Interface em comercial na plataforma SKY (BROADBAND, 2006)....... 23

Figura 2-13 - Interface em outro canal da plataforma SKY (BROADBAND, 2006) .....23

Figura 2-14 - Diagrama de exemplo da relação entre usuários, terminais de acesso e

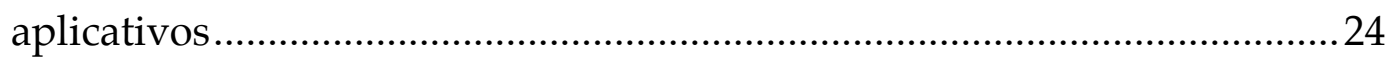

Figura 3-1 - Diagrama completo da metodologia adotada ......................................28 
Figura 4-1 - Exemplo de ambiente de uso de Torcedor Antenado

Figura 4-2 - Exemplo ambiente de uso de Mãe Ocupada ...........................................51

Figura 4-3 - Relação única entre usuário, controle e aparelho ...................................5 52

Figura 4-4 - Relação passível de dúvida com mais de um controle............................52

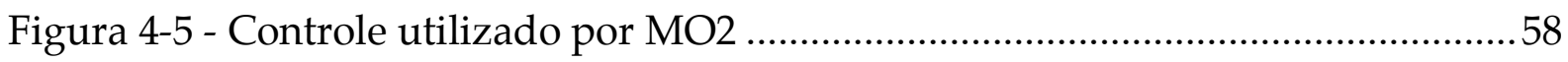

Figura 4-6 - Área visível e bordas de segurança do sistema PAL-M..........................65

Figura 4-7 - Alternativas para adequação do conteúdo a um formato de tela diferente 66

Figura 4-8 - Exemplo padrão de moiré ................................................................67

Figura 4-9 - Exemplo de tipo serifado e sem serifa e efeito de anti-alias aplicado à letra e. 68

Figura 4-10 - Exemplos famílias de tipos adequadas para TV. 69

Figura 4-11 - Mapa de navegação da plataforma TV aberta.....................................72

Figura 4-12 - Informações sobre canal na plataforma TV aberta ..............................74

Figura 4-13 - Detalhes das informações sobre canal na plataforma TV aberta............74

Figura 4-14 - Indicador de volume da plataforma TV aberta....................................75

Figura 4-15 - Menu de configurações da plataforma TV aberta...................................75

Figura 4-16 - Controle remoto da plataforma TV aberta ........................................76

Figura 4-17 - Guia de programação impresso da plataforma TV aberta ......................77

Figura 4-18 - Navegação da plataforma TV aberta...................................................78

Figura 4-19 - Mapa de navegação da plataforma TV a cabo analógica ....................... 80

Figura 4-20 - Canal com guia de programação não-interativo.................................... 81

Figura 4-21 - Detalhe de canal com guia de programação não-interativo ...................81 
Figura 4-22 - Controle remoto da plataforma TV a cabo analógica..... 82

Figura 4-23 - Guia de programação impresso da plataforma TV a cabo analógica.....83

Figura 4-24 - Terminal de acesso da plataforma TV a cabo analógica 84

Figura 4-25 - Navegação da plataforma TV a cabo analógica 84

Figura 4-26 - Mapa de navegação da plataforma DirecTV 86

Figura 4-27 - Tarja de informações da plataforma DirecTV 88

Figura 4-28 - Detalhes da tarja de informações da plataforma DirecTV 88

Figura 4-29 - Tarja com sinopse da plataforma DirecTV . 89

Figura 4-30 - Detalhe da tarja com sinopse da plataforma DirecTV 89

Figura 4-31 - Guia de programação com sinopse da plataforma DirecTV 90

Figura 4-32 - Detalhes do guia de programação com sinopse da plataforma DirecTV

Figura 4-33 - Guia de programação por ícones da plataforma DirecTV 91

Figura 4-34 - Detalhes do guia de programação por ícones da plataforma DirecTV ..91

Figura 4-35 - Controle remoto da plataforma DirecTV 92

Figura 4-36 - Navegação de TV da plataforma DirecTV 93

Figura 4-37 - Navegação do guia da plataforma DirecTV. 94

Figura 4-38 - Mapa de navegação da plataforma TVA Digital.................................... 96

Figura 4-39 - Tarja de informações da plataforma TVA Digital................................98

Figura 4-40 - Detalhes da tarja de informações da plataforma TVA Digital .................98

Figura 4-41 - Opções de legenda e áudio alternativo da plataforma TVA Digital ......99

Figura 4-42 - Detalhes das opções de legenda e áudio alternativo da plataforma TVA

Digital. 99 
Figura 4-43 - Tela inicial da plataforma TVA Digital ............................................. 100

Figura 4-44 - Detalhes da tela inicial da plataforma TVA Digital ............................. 100

Figura 4-45 - Guia de programação da plataforma TVA Digital ............................... 102

Figura 4-46 - Detalhes do guia de programação da plataforma TVA Digital .............102

Figura 4-47 - Tela de sinopse da plataforma TVA Digital ...................................... 103

Figura 4-48 - Detalhes da tela de sinopse da plataforma TVA Digital ...................... 103

Figura 4-49 - Controle remoto da plataforma TVA Digital ...................................... 105

Figura 4-50 - Navegação de TV da plataforma TVA Digital .................................... 107

Figura 4-51 - Navegação do guia da plataforma TVA Digital.................................. 108

Figura 4-52 - Navegação do portal da plataforma TVA Digital................................ 109

Figura 4-53 - Mapa de navegação da plataforma NET Digital................................. 111

Figura 4-54 - Tarja de informações da plataforma NET Digital ................................ 113

Figura 4-55 - Detalhes da tarja de informações da plataforma NET Digital .............. 113

Figura 4-56 - Opções de legenda e áudio alternativo da plataforma NET Digital .... 114

Figura 4-57 - Detalhes das opções de legenda e áudio alternativo da plataforma NET

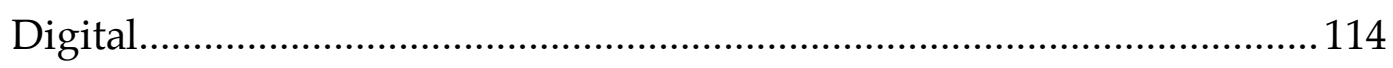

Figura 4-58 - Tela de portal da plataforma NET Digital ......................................... 115

Figura 4-59 - Detalhes da tela de portal da plataforma NET Digital ........................ 115

Figura 4-60 - Guia de programação da plataforma NET Digital................................ 116

Figura 4-61 - Detalhes do guia de programação da plataforma NET Digital ............116

Figura 4-62 - Tela de sinopse da plataforma NET Digital ....................................... 118

Figura 4-63 - Detalhes da tela de sinopse da plataforma NET Digital ...................... 118 
Figura 4-64 - Aplicativo com tabela de jogos de campeonato de futebol da plataforma NET Digital

Figura 4-65 - Detalhes do aplicativo com tabela de jogos de campeonato de futebol da plataforma NET Digital 119

Figura 4-66 - Interface para entrada de texto em aplicativo da plataforma NET Digital

Figura 4-67 - Detalhes da interface para entrada de texto em aplicativo da plataforma

NET Digital 120

Figura 4-68 - Controle remoto da plataforma NET Digital. 122

Figura 4-69 - Navegação de TV da plataforma NET Digital 123

Figura 4-70 - Navegação do guia da plataforma NET Digital 125

Figura 4-71 - Navegação do portal da plataforma NET Digital. 126

Figura 4-72 - Navegação do aplicativo com tabela de jogos de campeonato de futebol da plataforma NET Digital. 127

Figura 4-73 - Mapa de navegação da plataforma SKY.... 129

Figura 4-74 - Tarja de informações da plataforma SKY 131

Figura 4-75 - Detalhes da tarja de informações da plataforma SKY 131

Figura 4-76 - Tarja de áudio e legenda alternativos da plataforma SKY 132

Figura 4-77 - Detalhes da tarja de áudio e legenda alternativos da plataforma SKY 132 Figura 4-78 - Tela de mosaico principal da plataforma SKY 133

Figura 4-79 - Detalhes da tela de mosaico principal da plataforma SKY 133

Figura 4-80 - Tela de mosaico de esportes da plataforma SKY 135

Figura 4-81 - Detalhes da tela de mosaico de esportes da plataforma SKY 135

Figura 4-82 - Guia de programação da plataforma SKY 136 
Figura 4-83 - Detalhes do guia de programação da plataforma SKY 136

Figura 4-84 - Tela de informações do programa da plataforma SKY 137

Figura 4-85 - Detalhes da tela de informações do programa da plataforma SKY .... 137

Figura 4-86 - Aplicativo com tabela de jogos de campeonato de futebol da plataforma SKY 138

Figura 4-87 - Detalhes do aplicativo com tabela de jogos de campeonato de futebol da plataforma SKY 138

Figura 4-88 - Programa de TVe do canal Globo News. 139

Figura 4-89 - Detalhes do programa de TVe do canal Globo News 139

Figura 4-90 - Controle remoto da plataforma SKY 141

Figura 4-91 - Navegação de TV da plataforma SKY 143

Figura 4-92 - Navegação do guia de programação da plataforma SKY 144

Figura 4-93 - Navegação do portal da plataforma SKY . 145

Figura 4-94 - Navegação do aplicativo com tabela de jogos de campeonato de futebol da plataforma SKY 147

Figura 4-95 - Mapa de navegação da plataforma SKY+..... 149

Figura 4-96 - Tarja de informações da plataforma SKY+ 151

Figura 4-97 - Detalhes da tarja de informações da plataforma SKY+ 151

Figura 4-98 - Tarja de informações de programa gravado da plataforma SKY+ 152

Figura 4-99 - Detalhes da tarja de informações de programa gravado da plataforma

SKY+. 152

Figura 4-100 - Guia de programação da plataforma SKY+ 153

Figura 4-101 - Detalhes do guia de programação da plataforma SKY+ 153

Figura 4-102 - Lista de programas gravados da plataforma SKY+ 154 
Figura 4-103 - Detalhes da lista de programas gravados da plataforma SKY+ 154

Figura 4-104 - Aplicativo com tabela de jogos de campeonato de futebol da plataforma SKY.+ 155

Figura 4-105 - Detalhes do aplicativo com tabela de jogos de campeonato de futebol da plataforma SKY+..... 155

Figura 4-106 - Aplicativo de TVi da plataforma SKY+ 156

Figura 4-107 - Detalhes do aplicativo de TVi da plataforma SKY+ 156

Figura 4-108 - Controle remoto da plataforma SKY+ 157

Figura 4-109 - Navegação do aplicativo com tabela de jogos de campeonato de futebol da plataforma SKY+

Figura 4-110 - Mapa de navegação proposto 162

Figura 4-111 - Uso de tarja sobreposta ao programa de TVe do canal Fox News 164

Figura 4-112 - Uso de vídeo reduzido dividido em quatro no programa de TVe do canal Disney (BROADBAND, 2006)

Figura 4-113 - Menu de desdobrar em programa da emissora BBC (BROADBAND, 2006) 166

Figura 4-114 - Menu de desdobrar no Guia de Estilo da Arvid (ARVID, 2004) ........ 166

Figura 4-115 - Simulação de menu de opções sobre aplicativo de TV ativa 167

Figura 4-116 - Esquema de controle remoto com teclas e grupos propostos ..... 172

Figura 4-117 - Navegação de TV no modelo proposto. 174

Figura 4-118 - Navegação do guia no modelo proposto. 175

Figura 4-119 - Navegação do portal no modelo proposto 175

Figura 4-120 - Navegação de aplicativo de TV ativa no modelo proposto 176 


\section{Lista de Tabelas}

Tabela 2-1 - Resumo dos benefícios da consistência 14

Tabela 2-2 - Definições de TVi encontradas na literatura 17

Tabela 3-1 - Relação entre usuários entrevistados e sistema de tv utilizado 34

Tabela 4-1 - Comparação entre as 4 classificações de usuários de TVi. 43

Tabela 4-2 - Nomes das telas principais do mapa de navegação das diversas plataformas 161

Tabela 4-3 - Proposta de nomes para as telas principais do mapa de navegação ..... 161

Tabela 4-4 - Nomes das teclas do controle remoto em função de sua funcionalidade e plataforma 168

Tabela 4-5 - Teclas utilizadas para tarefas típicas no contexto de TV. 176

Tabela 4-6 - Teclas utilizadas para tarefas típicas no contexto de guia de programação 177

Tabela 4-7 - Teclas utilizadas para tarefas típicas no contexto de portal 177

Tabela 4-8 - Teclas utilizadas para tarefas típicas no contexto de aplicativos de TV ativa.... 178

Tabela 5-1 - Relação entre requisitos e modelos de usuários 181

Tabela 5-2 - Comparação entre o modelo de navegação proposto e a solução alternativa 188 


\section{Lista de Siglas}

ITU International Telecommunications Union

PVR Personal Video Recorder

SBTVD Sistema Brasileiro de TV Digital

SMS Short Message Service

TV Televisão

TVe TV Expandida

TVi TV interativa

UIMS User Interface Management System

WIMP Windows Icons Menus and Pointer 


\section{Sumário}

Capítulo 1 - Introdução 1

1.1 Objetivos 4

1.2 Motivação. 4

1.3 Relevância 5

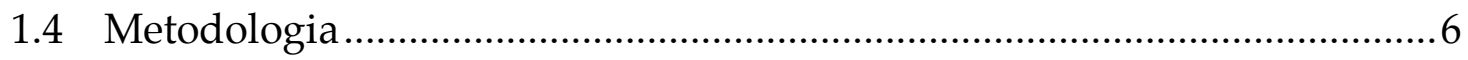

1.5 Resultados Esperados .......................................................................

1.6 Estrutura da Dissertação................................................................

Capítulo 2 - Consistência e TV Interativa ......................................................

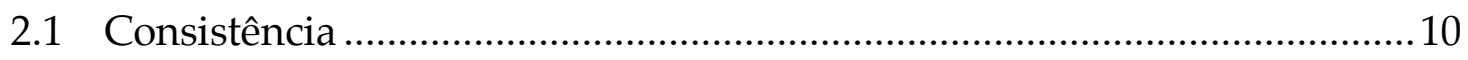

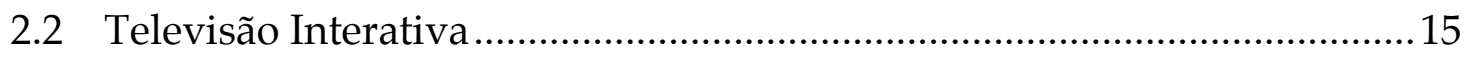

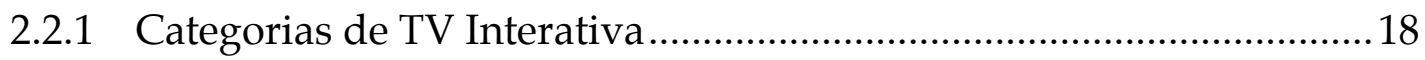

2.2.2 Usabilidade na TV Interativa....................................................... 21

2.2.3 Consistência na TV Interativa......................................................22

Capítulo 3 - Metodologia para a Seleção de Boas Práticas de Interfaces ..............27

3.1 Modelagem de Usuário....................................................................29

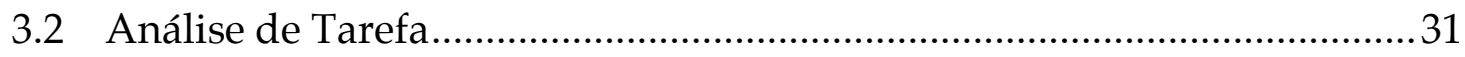

3.3 Diretrizes Gerais de Interface ........................................................ 35

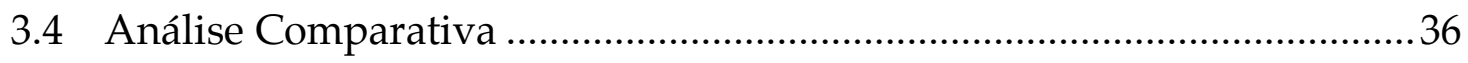

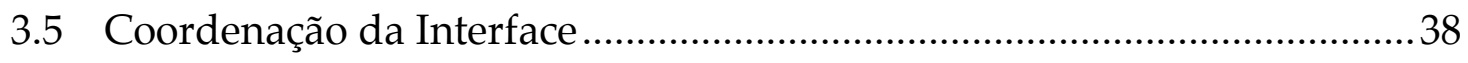

Capítulo 4 - Aspectos Experimentais da Metodologia Proposta ..........................39 


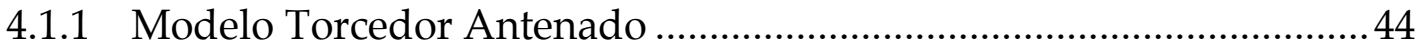

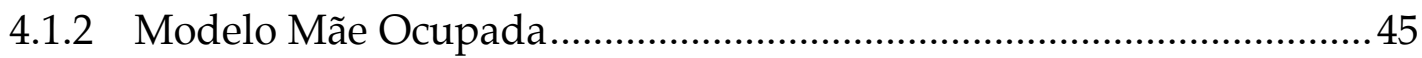

4.1.3 Modelo Meia Idade com Ajuda .................................................... 45

4.1.4 Modelo Torcedor com Baixa Alfabetização.........................................46

4.1.5 Resultados para todos os Modelos...............................................47

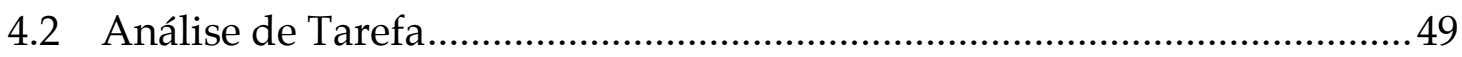

4.2.1 Análise do Ambiente................................................................49

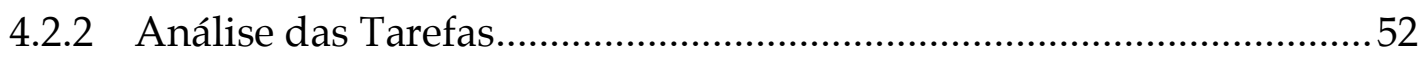

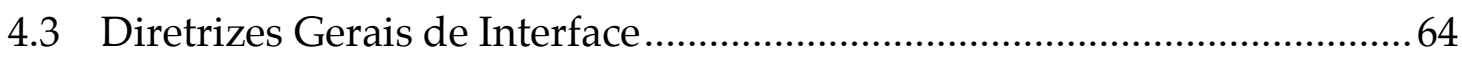

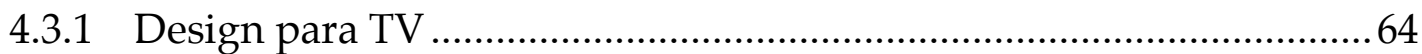

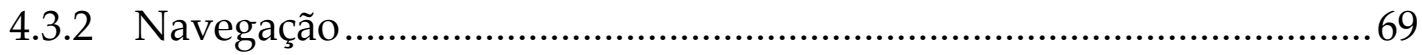

4.3.3 Dispositivo de Interação ......................................................... 70

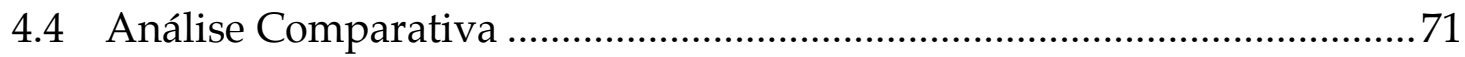

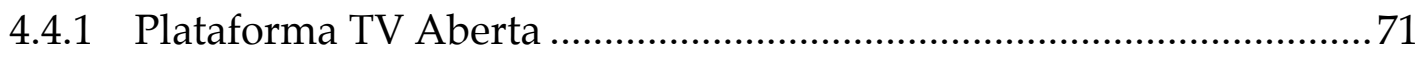

4.4.2 Plataforma TV a Cabo Analógica ..................................................79

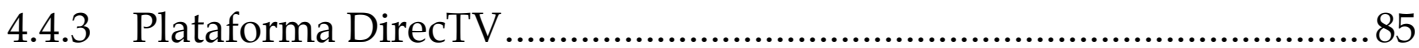

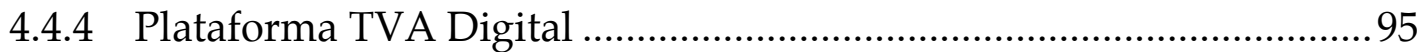

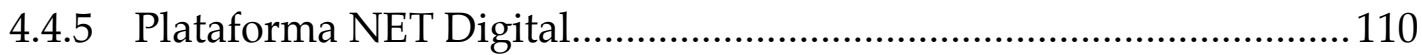

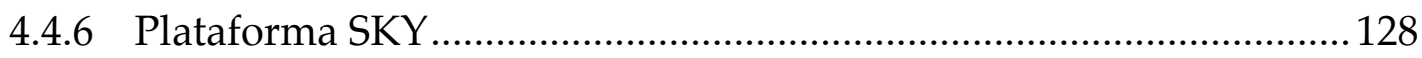

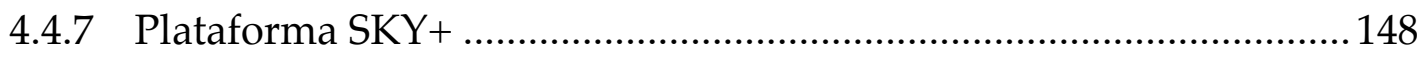

4.5 Coordenação da Interface ............................................................. 160 


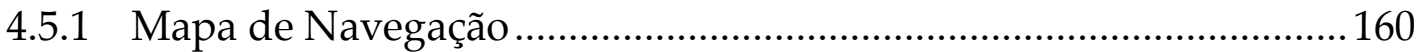

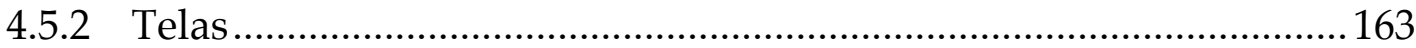

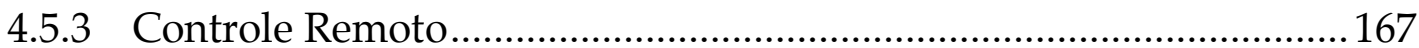

4.5.4 Modelo de Navegação................................................................... 172

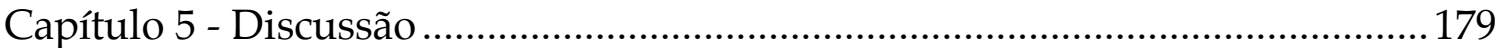

5.1 Modelagem de Usuário.............................................................................. 180

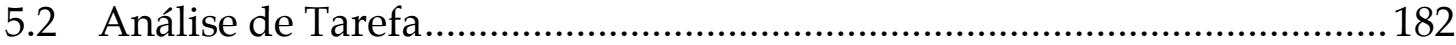

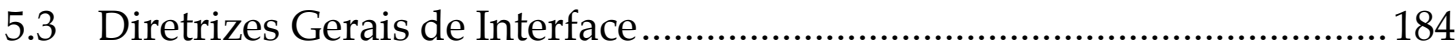

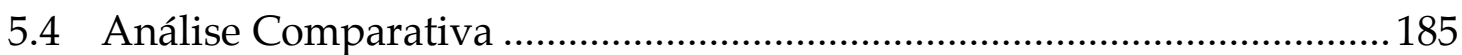

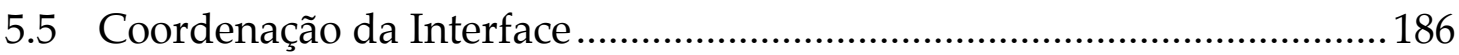

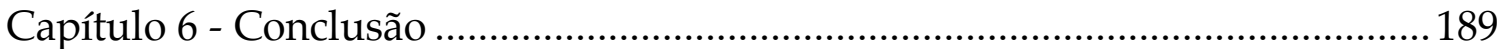

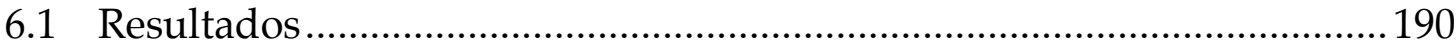

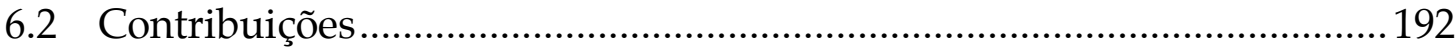

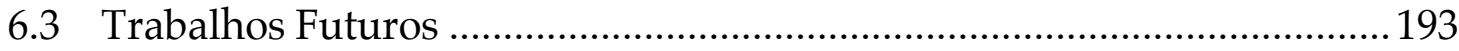

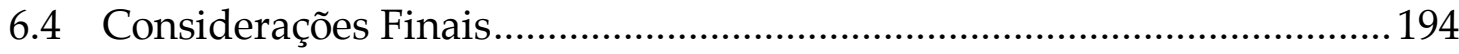




\section{Capítulo 1 - Introdução}

“No início dos anos 60 McLuhan observou que a convivência com tecnologias eletrônicas e mecânicas simultaneamente era "o drama peculiar do século vinte". O grande drama das próximas décadas acontecerá no cruzamento do analógico com o digital. Como no coro de uma tragédia grega, filtros de informação irão nos guiar nesta transição, traduzindo os zeros e uns da linguagem digital nas mais familiares imagens analógicas da vida quotidiana. Estas "metaformas", estes mapeamentos de bits (bitmappings) ocuparão praticamente todas as faces da sociedade moderna: trabalho, diversão, romance, família, arte erudita, cultura pop, política. Mas a forma em si será a mesma, apesar de suas diversas aparências, manifestando-se em um estranho novo espaço entre meio e mensagem. Este espaço é o que chamamos de interface." ${ }^{1}$

${ }^{1}$ JOHNSON, S. Interface Culture: How New Technology Transforms the Way We Create and Communicate. New York: HarperCollins, 1997. 264 p. Tradução do autor. 
Nas últimas décadas, principalmente a partir do começo da década de 90, observou-se um esforço mundial de padronização e implantação da TV digital pelo mundo. Este esforço foi acompanhado de uma intensa evolução da informática e tecnologias associadas como a internet, as comunicações móveis, o desempenho dos computadores e a miniaturização dos componentes eletrônicos. Este cenário evolutivo propiciou o incremento das pesquisas na área de TV interativa (TVi) inserida em um contexto mais abrangente, o da TV digital.

Particularmente no Brasil, ocorreu nos últimos anos a intensificação do debate público em torno das definições relacionadas com o SBTVD (Sistema Brasileiro de TV Digital), que envolve grandes interesses econômicos, sociais e científicos. Neste contexto nacional a perspectiva da transição do atual cenário de radiodifusão televisiva analógica baseada na oferta de serviços de som e imagens para um cenário baseado na oferta de serviços de som, imagens e interatividade, conforme descrito no Decreto No 5.820, de 29 de junho de 2006 (BRASIL, 2006), abre possibilidades inéditas de investigação em torno da TV interativa (TVi) ao longo do processo de implantação do SBTVD na próxima década.

Os desafios da interatividade na TV digital são muitos, dentre os quais destacamos a mudança de paradigma para o telespectador (que passa a ser usuário), a produção de conteúdo interativo e o desempenho computacional das aplicações. Neste trabalho daremos ênfase às questões relacionadas à interface com o usuário da TV interativa (TVi), abordando especificamente a questão da consistência.

A consistência é considerada na literatura uma característica fundamental para a boa usabilidade de Interfaces Humano-Computador (DIX et al., 1998; COOPER; REIMANN, 2003; SHNEIDERMAN, 1998; NIELSEN, 1994; ISO, 1998; APPLE COMPUTER, 1992). Ela tem um impacto direto e indireto em 
diversos atributos de usabilidade como facilidade de aprendizagem, facilidade de uso e satisfação subjetiva. No capítulo 2 abordaremos com mais detalhes a questão da consistência, dando ênfase à aplicação em TVi.

Durante os trabalhos da primeira fase do $\operatorname{SBTVD}^{2}$ (Sistema Brasileiro de TV Digital), no biênio 2004 e 2005, observamos que a questão da consistência em interfaces de TVi é um problema recorrente e aberto nos países em que a TV digital está sendo implantada (GAWLINSKI, 2003). Como conseqüência da falta de consistência, estão ocorrendo nestes países diversos problemas de usabilidade (KLEIN; KARGER; SINCLAIR, 2003), com impactos negativos para a população, que não faz uso pleno dos novos recursos oferecidos pela TVi, para a indústria de complexo eletrônico, com incremento da taxa de devolução de aparelhos e aumento de custos de suporte pós-venda e para o governo pelo atraso na adoção universal desta nova tecnologia.

Existem diversas abordagens para se atingir a consistência em Interfaces Humano-Computador (NIELSEN, 2002), que podem ser agrupadas em dois grandes grupos: as baseadas em imposição e as baseadas em promoção.

Nas abordagens baseadas em imposição, a consistência pode ser atingida por meio de um controle centralizado que impõe um estilo de interface. São exemplos: uma empresa que coordena a interface de todos os seus produtos e um escritório onde todos os computadores têm a mesma configuração. De maneira geral as abordagem de consistência baseadas em imposição são adequadas a ambientes controlados e sem grandes inovações. Em um ambiente de transição e com muito potencial para transformação estas abordagens tendem a ser restritivas e podem inibir a inovação.

Nas abordagens baseadas em promoção a consistência pode ser atingida através de implementações de referência, que podem servir como modelo, ou através de código compartilhado, como no caso de toolkits, UIMSs (User

\footnotetext{
${ }^{2} \mathrm{O}$ autor participou do SBTVD como pesquisador na área de design de interfaces no consórcio TAR - Terminal de Acesso de Referência, liderado pelo Laboratório de Sistemas Integráveis da Escola Politécnica da Universidade de São Paulo
} 
Interface Management System) e folhas de estilo (stylesheet). Este grupo de abordagens é menos restritivo e cria maiores oportunidades para a inovação.

Consideramos a busca pela consistência como um grande desafio à implantação da TVi no Brasil, visto que a produção de conteúdo será feita por diversos atores e haverá uma grande diversidade de plataformas de hardware. Estes fatores, em um cenário brasileiro e mundial de intensa renovação, levam a crer que as abordagens de consistência de interfaces com o usuário baseadas em promoção parecem mais promissoras em termos de investigação e desenvolvimento.

\subsection{Objetivos}

O objetivo principal deste trabalho é investigar as questões relacionadas à consistência de interfaces com usuário em TV interativa, considerando seus diversos aspectos teóricos e de implementação.

Dentre os objetivos específicos destacamos:

- investigar a questão da consistência e suas abordagens na literatura de Interfaces Humano-Computador;

- uma vez que a consistência é uma característica relativa a um modelo, buscar identificar modelos de interfaces de TVi que devem ser:

- exemplos de boas práticas a serem seguidas;

- consistentes entre si;

- na ausência de modelos que atendam estas demandas, procurar propor alternativas que possam se tornar modelos.

\subsection{Motivação}

Durante as pesquisas do projeto SBTVD, foi possível perceber que a falta de consistência tem impactos negativos no design de interfaces de TVi, em especial para populações com baixa alfabetização, idosos e usuários com necessidades especiais (KLEIN; KARGER; SINCLAIR, 2003). Desta forma, a consistência é de vital importância para o sucesso da TVi no Brasil. 
Existem poucos estudos focados no design de interfaces para TVi (CHORIANOPOULOS, 2004), muito embora este seja um tema de grande importância (GAWLINSKI, 2003). Não foi possível encontrar nenhum trabalho que abordasse especificamente a questão da consistência em interfaces com o usuário para TVi.

Este tema é também parte de uma linha de pesquisa sobre TV digital do LSI (Laboratório de Sistemas Integráveis) da Escola Politécnica da Universidade de São Paulo. Esta linha de pesquisa tem seu foco no terminal de acesso, o equipamento utilizado pelo usuário para recepção e interação com a TV digital, e compreende pesquisas nas áreas de hardware, algoritmos de codificação e decodificação (codecs), sistema operacional, aplicativos e design de interfaces. Esta complementaridade entre áreas permite a sinergia entre campos distintos e um enfoque multifacetado sobre o tema da TVi, que foram de grande valia para o desenvolvimento deste trabalho.

\subsection{Relevância}

Conforme já mencionado, a falta de consistência tem efeitos negativos para todos os envolvidos na cadeia de produção e consumo da TVi.

Para o usuário o sistema torna-se mais difícil de ser utilizado, o que inibe o uso de novos recursos e pode criar uma aversão à tecnologia e mesmo sua eventual rejeição por parte da população (KLEIN; KARGER; SINCLAIR, 2004).

Para os produtores de conteúdo a falta de consistência pode obrigar à coexistência de diversas versões de um mesmo aplicativo, o que aumenta custos de produção e de manutenção. Como efeito colateral da rejeição da tecnologia por parte dos usuários também há uma redução o público atingido por este conteúdo.

Para a indústria de complexo eletrônico, uma menor adoção da tecnologia reduz a escala de vendas alcançada. A dificuldade de uso também aumenta a taxa de devolução e os custos de suporte pós-venda (NIELSEN, 2002). No Reino Unido, por exemplo, a taxa de devolução de terminais de acesso che- 
gou a $25 \%$ e foi necessário dar suporte para $46 \%$ dos usuários (KLEIN;

KARGER; SINCLAIR, 2003).

Para o país, a rejeição da tecnologia atrasa a adoção universal da TV digital, o que pode provocar um atraso na conclusão do cronograma de transição da TV analógica para a TV digital. Este atraso significa que será necessário ocupar o espectro de radiofreqüência utilizado para a transmissão simultânea nos formatos analógico e digital por mais tempo. Conseqüentemente este espectro, um recurso valioso e limitado, não poderá ser utilizado para outros fins, acarretando perdas para o país.

Desta forma, a consistência de interfaces com o usuário para TVi traz melhorias sociais e econômicas em grande escala.

\subsection{Metodologia}

A metodologia utilizada tem cinco etapas: modelagem de usuário, análise de tarefa, diretrizes gerais de interface, análise comparativa e coordenação da interface. A Figura 1-1 apresenta um diagrama resumido da metodologia adotada.

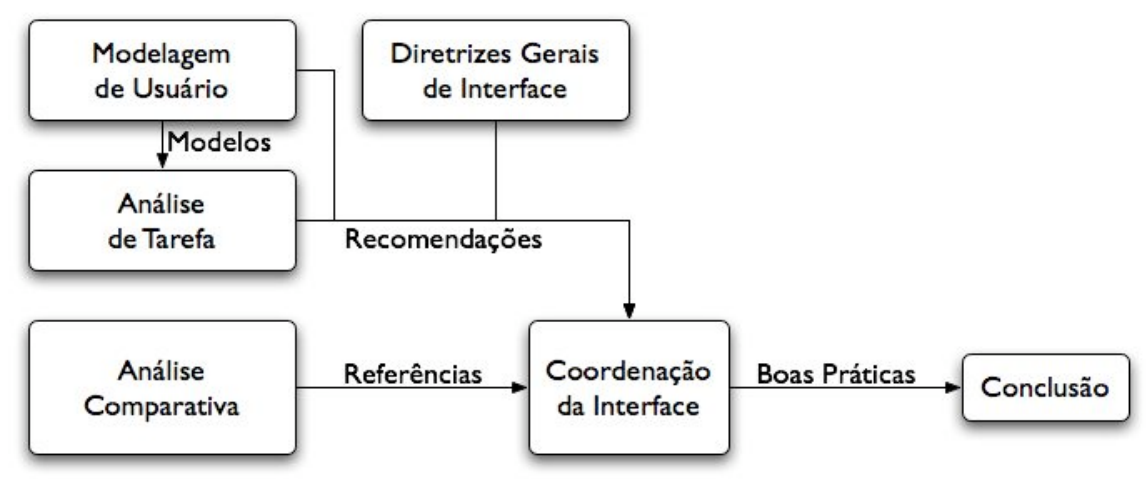

Figura 1-1 - Diagrama resumido da metodologia adotada

As primeiras duas etapas buscam informações sobre os usuários, suas tarefas e seu contexto de uso, que são a base de uma boa usabilidade (ISO, 1998). A etapa de diretrizes gerais de interface busca na literatura princípios que orientem o processo de design de interfaces. Estas três etapas geram recomendações para o processo de coordenação da interface. 
A análise comparativa procura observar os diversos enfoques adotados para resolver questões de design de interfaces em plataformas já implementadas (NIELSEN, 1994). Esta análise permite perceber as vantagens e desvantagens dos enfoques utilizados e serve como referência para a etapa de coordenação de interface.

A etapa de coordenação de interface verifica a consistência entre as diversas partes de um sistema (NIELSEN, 1994) por meio de uma inspeção de consistência (SHNEIDERMAN, 1998), que procura resolver problemas de consistência utilizando as recomendações extraídas das etapas inicias deste trabalho. Nesta etapa também são elaboradas novas propostas caso as soluções encontradas não sejam consideradas adequadas.

\subsection{Resultados Esperados}

O resultado esperado deste trabalho é um conjunto de exemplos de interfaces de TVi que possam servir como modelos para o desenvolvimento de aplicativos. Dentre os exemplos esperamos elencar:

- um mapa de navegação;

- um conjunto de funcionalidades mínimas para um controle remoto;

- modelo de navegação adequados à TVi.

Como resultados secundários deste trabalho esperamos dar início à modelagem de usuários de TVi no Brasil, assim como obter uma compreensão inicial de suas tarefas e seu contexto de uso. Também esperamos obter uma compilação de diretrizes gerais de interface para TVi.

\subsection{Estrutura da Dissertação}

O texto encontra-se organizado em seis capítulos, conforme apresentado na Figura 1-2. O capítulo inicial fornece uma visão inicial sobre o problema estudado, sobre a proposta deste trabalho e sobre sua importância. O segundo capítulo apresenta as bases teóricas deste trabalho e está dividido em duas partes, consistência e TV interativa. 


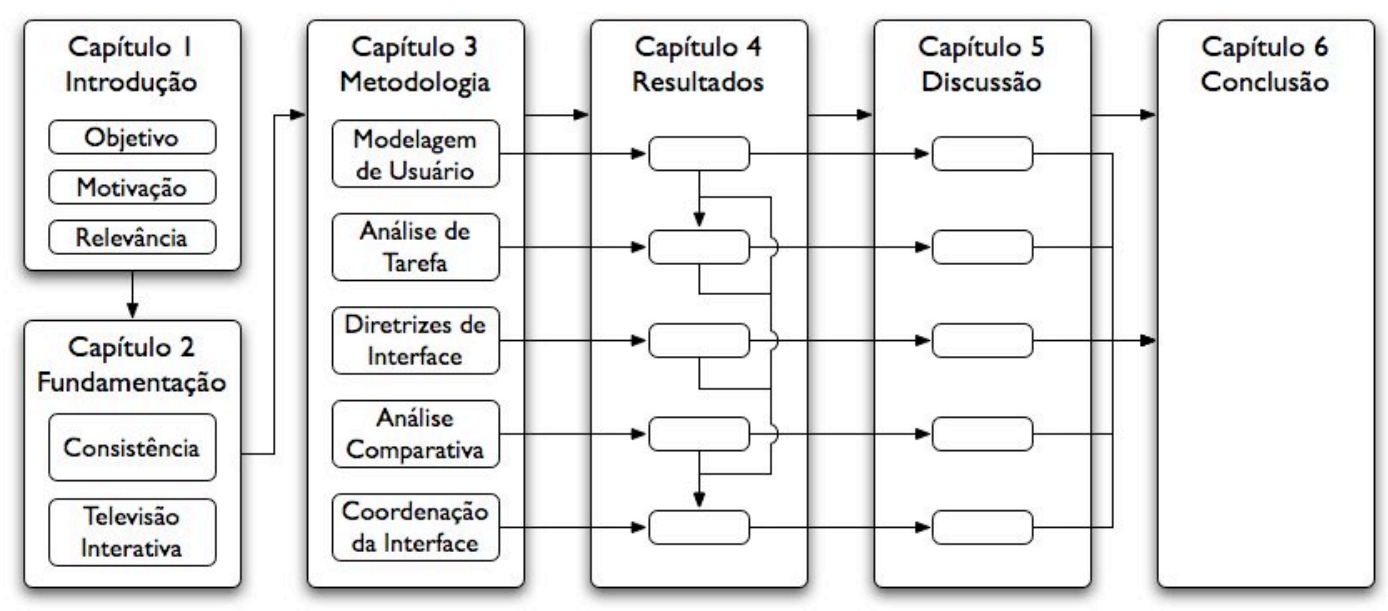

Figura 1-2 - Diagrama da estrutura da dissertação

Os capítulos 3, 4 e 5 estão sub-divididos nas cinco etapas que compõe a metodologia adotada. No capítulo 3 são apresentados os detalhes metodológicos das cinco etapas, no capítulo 4 são apresentados os resultados encontrados e no capítulo 5 é feita a discussão.

O último capítulo contém as conclusões finais do trabalho e as indicações de possíveis trabalhos futuros. 


\section{Capítulo 2 - Consistência e TV Interativa}

“Mas independentemente de suas funções, o rádio é unidirecional quando deveria ser bidirecional. É simplesmente um aparato para distribuição, para mera divulgação. Então dou aqui uma sugestão positiva: modifiquem este aparelho de distribuição para comunicação. O rádio seria o melhor aparelho possível para comunicação na vida pública, uma vasta rede de conexões. Quero dizer, seria se ele soubesse transmitir assim como sabe receber, soubesse permitir o ouvinte falar assim como ouvir, soubesse trazê-lo para uma relação ao invés de isolá-lo. Seguindo este princípio, o rádio deveria evoluir de uma empresa de distribuição e organizar seus ouvintes como seus fornecedores. Toda tentativa do rádio de dar uma condição realmente pública para um evento Público é um passo na direção correta." ${ }^{3}$

${ }^{3}$ BRECHT, B. Der Rundfunk als Kommunikationsapparat, 1932. Tradução do autor baseado em versão inglesa. 
Neste capítulo apresentamos os pressupostos teóricos deste trabalho e tecemos considerações baseadas em uma revisão da literatura feita sobre os dois assuntos que são a base do capítulo, consistência e TV interativa.

\subsection{Consistência}

Uma busca na literatura por uma definição do termo nos traz definições e abordagens distintas para o entendimento da consistência. Dix et al. (1998, tradução do autor) descreve consistência como: "Consistência se relaciona com a semelhança em comportamento que ocorre em situações similares ou em tarefas com objetivos similares." Smith et al. (1983, tradução do autor) diz: "Consistência dita que mecanismos devem ser usados da mesma forma onde quer que ocorram." Shneiderman (1998, tradução do autor), por outro lado, não procura definir consistência e afirma que: "a definição de consistência é muito difícil e tem muitos níveis, que eventualmente estão em conflito". Este mesmo autor descreve diversos níveis onde a consistência pode existir, como a consistência de comandos (os mesmos comandos produzem mesmos resultados) consistência visual (as telas devem ter leiaute, uso de cores e de fontes semelhante) e consistência de nomenclatura (o nome para um comando deve ser sempre o mesmo), entre outras. O guia de estilo da Apple (APPLE COMPUTER, 1992) também fala de diversas formas possíveis de consistência, mas elenca duas em especial, a consistência visual e a consistência de comportamento (o sistema se comporta sempre de maneira semelhante).

Mas se não existe uma definição completa para consistência na literatura é consenso que é uma característica fundamental para o design de boas interfaces (DIX et al., 1998; COOPER; REIMANN, 2003; SHNEIDERMAN, 1998; NIELSEN, 1994; ISO, 1998; APPLE COMPUTER, 1992). O principal benefício da consistência é permitir a transferência de conhecimento entre situações de 
uso. Por exemplo, um usuário que saiba utilizar a interface representada na Figura 2-1 é capaz de realizar diversas tarefas na mesma interface mesmo em uma língua que desconheça (Figura 2-2). Como a estrutura visual da página, os tamanhos, cores e sublinhados em fontes são consistentes é possível prever o funcionamento da página mesmo sem compreender seu significado.

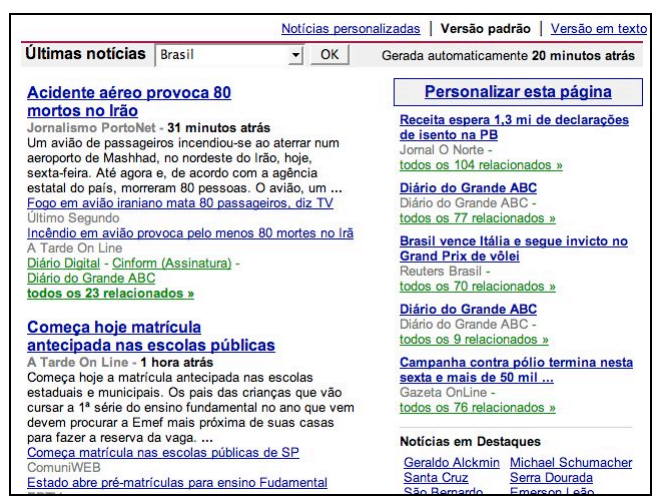

Figura 2-1 - Exemplo de interface em português

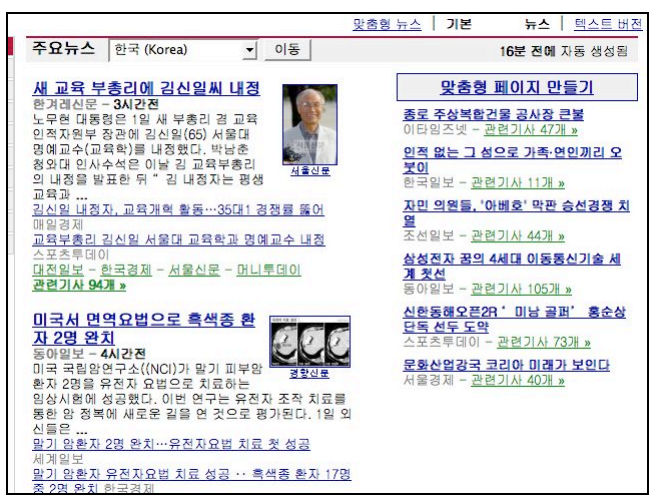

Figura 2-2 - Exemplo da mesma interface em outra língua

Este exemplo demonstra as duas formas de consistência citadas no guia de estilo da Apple (APPLE COMPUTER, 1992). Em um primeiro momento, a consistência visual entre as duas interfaces permite ao usuário reconhecer os elementos da página como análogos ao modelo conhecido, e prever o resultado de seu uso. No segundo momento, quando o usuário utiliza de fato a interface, a consistência de comportamento faz com que o resultado obtido esteja de acordo com o resultado esperado. A tarefa é realizada com sucesso, o que significa que a transferência de conhecimento entre situações de uso ocorreu de fato.

Considerando estes dois tipos de consistência, visual e de comportamento, como essenciais para que aconteça a transferência de conhecimento entre situações de uso, neste trabalho o termo consistência será utilizado para descrever uma característica de um sistema que tem aparência e comportamentos semelhantes em situações semelhantes. 
Através do uso de interfaces consistentes o usuário forma um modelo coerente da interface como um todo, o que permite generalizar sua experiência em uma interface específica para as diversas interfaces do sistema. Desta forma, com um conjunto pequeno de regras universalmente aplicáveis, o usuário pode utilizar novas interfaces com uma curva de aprendizagem mínima o que aumenta a facilidade de aprendizagem do sistema.

Dois outros aspectos importantes da consistência são evidenciados pelo fenômeno descrito por Raskin (2000, tradução do autor) como formação de hábito: “Quando você realiza uma tarefa repedidas vezes, ela tende a ficar mais fácil. ... Com a repetição, ou prática, sua competência se torna habitual, e você pode realizar a tarefa sem precisar pensar à respeito." Desta forma, enquanto a consistência aumenta a facilidade de aprendizagem em interfaces desconhecidas, em interfaces conhecidas ela é benéfica devido à facilidade de uso que proporciona.

O outro aspecto importante na relação entre consistência e formação de hábito é descrito por Raskin (Ibid., tradução do autor) nesta passagem:

“Hábitos podem ser tão fortes a ponto de se aproximarem de um vício, às vezes chegando ao nível de perda total do controle consciente. ... Eu enfatizo que não é possível desfazer um hábito por um simples ato de força de vontade; somente um treinamento demorado pode desfazer um hábito. Um designer pode plantar -- ou criar inadvertidamente -- uma perigosa armadilha ao permitir que, em um mesmo computador, dois ou mais aplicativos usados rotineiramente sejam diferentes apenas em alguns detalhes usados freqüentemente. Nesta circunstância, o usuário certamente desenvolverá hábitos que irão causar erros quanto tentar utilizar em um aplicativo os métodos que são exclusivos do outro."

Isto posto, é possível perceber que interfaces consistentes também reduzem a taxa de erros de uma interface. 
Considerando os benefícios da consistência em interfaces com o usuário, Nielsen (2002) faz uma análise extensa dos seus efeitos para o usuário final e para os desenvolvedores de software e fabricantes.

Do ponto de vista do usuário final, a consistência traz facilidade de aprendizagem, facilidade de uso e menor taxa de erros, conforme visto anteriormente. Como efeitos secundários da consistência, Nielsen (Ibid., tradução do autor) também cita:

\footnotetext{
"A menor taxa de erros e menor curva de aprendizagem levam a uma maior satisfação subjetiva e reduzem as frustrações com um sistema que o usuário é incapaz de utilizar. Finalmente, a consistência fortalece as expectativas do usuário com relação a ser capaz de utilizar novos softwares, proporcionando uma sensação de domínio e melhorando a auto-confiança."
}

Ainda segundo Nielsen (Ibid.), a consistência apresenta as seguintes vantagens para desenvolvedores de software e fabricantes de equipamentos:

- reduz custos de suporte: uma vez que o sistema é mais fácil de usar o suporte a usuários é menos utilizado. O próprio suporte também é mais simples, pois todas as interfaces são baseadas nas mesmas regras de funcionamento;

- reduz custos de desenvolvimento: como as soluções são baseadas em um padrão, ele é utilizado como referência e não é necessário desenvolver todas as partes de uma interface;

- reduz custos de implementação: facilita a reutilização de soluções já existentes e testadas;

- aumenta a expectativa de utilização e de vendas: por causa das vantagens ao usuário final citadas anteriormente, o produto deve ter uma melhor aceitação pelo público consumidor, o que leva a um aumento de uso e de vendas;

- tem o potencial de melhorar os aspectos estéticos da interface: o processo de design pode se preocupar com aspectos específicos do aplicativo que está sendo desenvolvido pois não é necessário reinventar todas as técnicas de interação necessárias para uma interface completa; 
- traz benefício do ponto de vista de marketing: as avaliações de um produto feitas pela imprensa levam cada vez mais em consideração a interface com o usuário, e conseqüentemente a sua consistência.

Na Tabela 2-1 apresentamos de forma resumida uma relação dos benefícios da consistência em interfaces com o usuário para o usuário final e para desenvolvedores de software e fabricantes de equipamentos.

Tabela 2-1 - Resumo dos benefícios da consistência

\begin{tabular}{|c|c|}
\hline $\begin{array}{l}\text { benefícios para } \\
\text { o usuário final }\end{array}$ & $\begin{array}{l}\text {-aumenta a facilidade de aprendizagem } \\
\text {-aumenta a facilidade de uso } \\
\text {-reduz da taxa de erros } \\
\text {-aumenta a satisfação subjetiva } \\
\text {-proporciona uma sensação de domínio } \\
\text {-melhora a auto-confiança }\end{array}$ \\
\hline $\begin{array}{l}\text { benefícios para } \\
\text { desenvolvedores } \\
\text { de software e fa- } \\
\text { bricantes de e- } \\
\text { quipamentos }\end{array}$ & $\begin{array}{l}\text {-reduz custos de suporte } \\
\text {-reduz custos de desenvolvimento } \\
\text {-reduz custos de implementação } \\
\text {-aumenta a expectativa de utilização e de vendas } \\
\text {-tem o potencial de melhorar os aspectos estéticos da in- } \\
\text { terface } \\
\text {-traz benefício do ponto de vista de marketing }\end{array}$ \\
\hline
\end{tabular}

Mas a consistência não traz apenas benefícios. Dix et al. (1998) e Nielsen (2002) fazem a ressalva de que a consistência, por ser sempre uma característica relativa a um modelo, pode ser prejudicial caso o modelo original não seja um bom modelo, não seja um modelo adequado a uma situação particular ou seja um modelo que tenha inconsistências internas.

A consistência é apenas um dos critérios de uma interface e um excesso de consistência pode levar a uma solução de mínimo denominador comum e impedir o surgimento de novas soluções e de inovação, o que faz com que em algumas situações possa ser melhor não ser consistente. 
Desta forma, de maneira geral a consistência deve ser sempre um objetivo, que só deve deixar de ser almejado quando existir um bom motivo para tal, pois caso a consistência não seja buscada, ela deixará de acontecer, conforme nos diz Nielsen (Ibid., tradução do autor):

"Consistência em interfaces com o usuário segue a segunda lei da termodinâmica: Se nada for feito, a entropia irá aumentar na forma de mais e mais inconsistências na interface com o usuário."

\subsection{Televisão Interativa}

Durante os anos 50 a Televisão se estabelece definitivamente como um novo meio. Começam a surgir formatos de programas mais apropriados para este meio e ela deixa de ser uma mera adaptação dos antigos programas de rádio (GAWLINSKI, 2003, p. 27). Neste ambiente surge o primeiro programa de TVi:

“Nos anos 50, uma forma de TV interativa simples mas inteligente foi criada na série infantil Winky Dink and You (1953-1957) da rede CBS. A interação era feita através de uma folha de plástico especial que as crianças podiam comprar em lojas de bairro ou através do correio para ser colocada sobre a tela da televisão. A folha de plástico era grudada à tela através da fricção criada quando a criança esfregava a folha com um pano especial.

No programa, o personagem animado - Winky Dink - encontrava muitos problemas. Por exemplo, um tigre poderia estar perseguindo Winky Dink até a borda de um desfiladeiro. Era então pedido às crianças que ajudassem Winky Dink com um giz especial desenhando uma ponte na folha de plástico para que ele pudesse escapar do tigre. Apesar da tecnologia ser rudimentar, as crianças tinham uma experiência de interação com a televisão e podiam ver ações na tela que (aparentemente) eram em resposta aos seus desenhos. Um problema 
com este formato, porém, era que algumas crianças não compravam a folha de plástico e simplesmente desenhavam sobre a tela da TV." (CAREY, 1996a, tradução do autor)

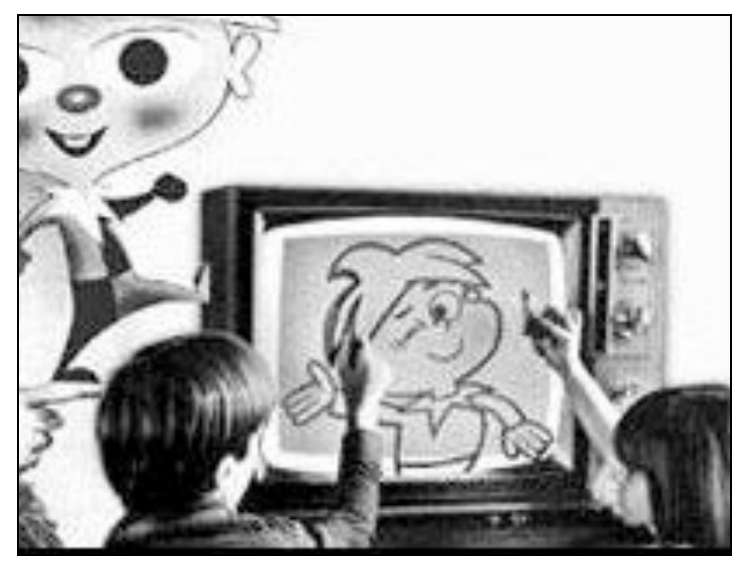

Figura 2-3 - Crianças desenhando na folha de plástico colocada sobre a tela de TV (THOMASSON, 2003).

Esta primeira iniciativa foi um grande sucesso (LU, 2005, p. 14) e desta data em diante existiram diversas implementações e experiências com objetivo, tamanhos e resultados bastante distintos. Gawlinski (2003) e Carey (1997) apresentam um histórico detalhado destas iniciativas onde é possível ver que enquanto o Teletexto e o Videotexto (este segundo na França) tiveram sucesso na sua implantação, diversas outras tentativas fracassaram ou foram interrompidas. Carey (Ibid.) cita três fatores que considera como os mais importantes para o insucesso destas tentativas:

- as plataformas ainda estavam em etapa de protótipo ou em desenvolvimento, e tinham muitos problemas técnicos;

- os equipamentos (terminais de acesso) eram ainda muito caros;

- as organizações não levaram em conta as modificações sociais que a inovação tecnológica trazia e não se adaptaram à nova realidade.

Loizides (2005) apresenta uma visão mais recente das experiências de TVi nos EUA, onde a TVi sofreu uma metamorfose. Enquanto nos anos 90 a TVi tentou ser uma junção de e-mail, internet e catálogo de compras, e enfrentou a concorrência direta da web e da internet, atualmente seu objetivo tem sido “tornar a experiência mais relevante e satisfatória para o usuário através de interatividade controlada pelo usuário"' (Ibid., tradução do autor). 
Outro ponto importante apresentado por Loizides é que o mercado de TVi está atingindo a massa crítica para se tornar financeiramente viável, o que nos EUA significa uma penetração de $15 \%$ a $20 \%$ do mercado. Finalmente a autora cita que a junção de baixo custo, disponibilidade de conteúdo e funcionalidade, fizeram do DVD uma das tecnologias mais rapidamente adotadas pelos consumidores e conclui que, existindo muitas semelhanças entre o DVD e a TVi, esta segunda pode seguir um caminho semelhante à primeira.

Mas, apesar de existir há mais de 50 anos, não existe uma definição clara do que é a TVi. Na Tabela 2-2 elencamos as definições encontradas na literatura.

Tabela 2-2 - Definições de TVi encontradas na literatura

\begin{tabular}{|l|l|}
\hline Ju, Angiolillo e & $\begin{array}{l}\text { um meio para entretenimento e informação baseado em: } \\
\text { Hicks (1994) } \\
\text { ênfase visual; } \\
\text { banda-larga para download; } \\
\text { recebido via TV; }\end{array}$ \\
\hline barey (1996b) & $\begin{array}{l}\text { que enfatiza o enfoque de entretenimento no acesso à in- } \\
\text { formação. }\end{array}$ \\
\hline $\begin{array}{l}\text { Gawlinski } \\
\text { são, em contraponto ao uso de um serviço de informação no }\end{array}$ \\
\hline computador pessoal.
\end{tabular}




\begin{tabular}{|l|l|}
\hline usuário; \\
b) termo genérico que cobre a convergência de televisão com \\
tecnologias digitais como computadores, PVRs, jogos eletrô- \\
nicos, dispositivos sem fio e telefones celulares e que possi- \\
bilita a interação do usuário.
\end{tabular}

Levando em consideração estas diversas definições existentes e o foco no usuário final, o termo TVi é utilizado neste trabalho para descrever o seguinte contexto:

- seus usos principais são entretenimento e informação;

- utiliza o paradigma atual da TV ao invés de tentar modificá-lo radicalmente;

- estende este paradigma de uma atitude exclusivamente passiva para uma atitude que inclui a possibilidade de escolha, ação e diálogo.

\subsubsection{Categorias de TV Interativa}

Como é natural em um novo meio, surgiram diversas manifestações de TVi com características bastante diferentes, tanto em termos técnicos quanto de uso. Na tentativa de melhor compreendê-las, e de mostrar suas semelhanças e diferenças, diversos autores criaram subclassificações para a TVi. No entanto, as classificações encontradas na literatura (FREED, 2000;

SRIVASTAVA, 2002, p. 99; GAWLINSKI, 2003, p. 7; LU, 2005, P. 27) acabam por misturar classificações baseadas na tecnologia utilizada (internet, vídeo sob demanda), no tipo de uso (jogos eletrônicos, guia de programação), na atividade comercial (banco, compras) e até no tipo de emissora (comunitária) de forma indistinta, o que compromete o seu objetivo inicial. Becker (2006) apresenta uma classificação simples e eficiente que define:

- aplicativo: todo software de TVi;

- aplicativo acoplado: tipo de aplicativo que tem relação com o conteúdo audiovisual do programa;

- aplicativo desacoplado: tipo de aplicativo que não tem relação com conteúdo audiovisual. 
Utilizando esta classificação como base foram criadas três categorias que serão utilizadas neste trabalho: TV Expandida, TV ativa e Infra-estrutura, descritos a seguir.

A classe de aplicativos acoplados utilizada por Becker (Ibid.) também é conhecida na literatura como Enhanced TV (eTV) (GAWLINSKI, 2003; LAMONT, 2003), que pode ser traduzido como TV Expandida (TVe). Como o próprio nome sugere, se refere a uma expansão do conteúdo televisivo existente hoje em dia. $\mathrm{O}$ foco de atenção do usuário se mantém no programa em questão e o conteúdo interativo existe em função do conteúdo audiovisual. Alguns exemplos típicos são: informação adicional sobre o assunto do programa (Figura 2-4 e Figura 2-5), escolha de câmera, votações e jogos de perguntas e respostas. Como este tipo de aplicativo está sempre associado a um programa de TV, pode ser chamado de programa de TVe para fazer referência ao programa como um todo (incluindo aplicativo e conteúdo audiovisual). O termo aplicativo de TVe normalmente se refere apenas ao código do programa.

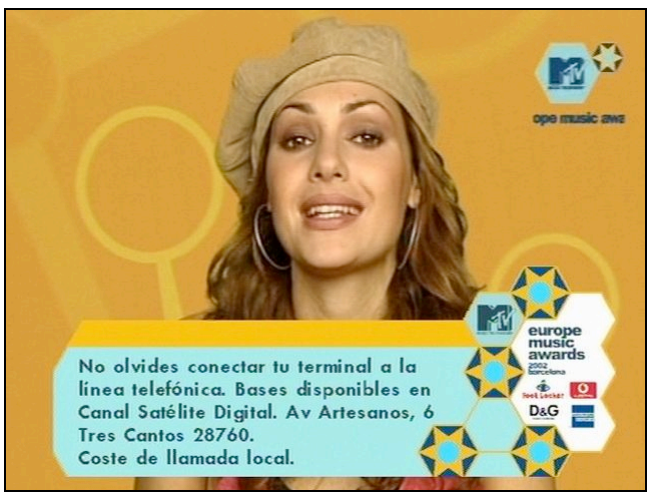

Figura 2-4 - Exemplo de TVe com tarja sobre vídeo (BROADBAND, 2006)

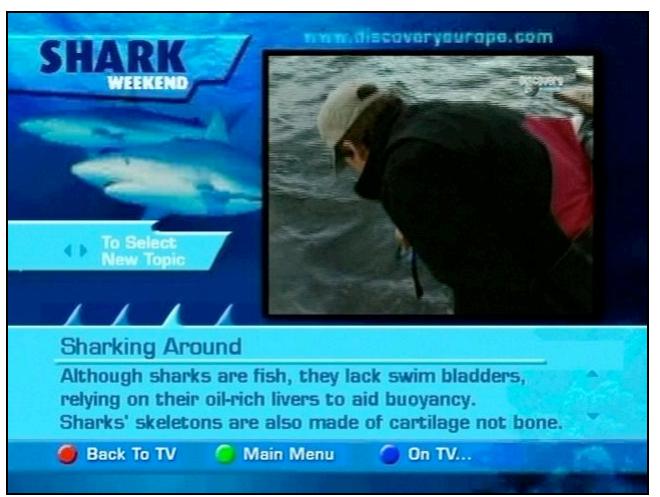

Figura 2-5 - Exemplo de TVe com vídeo redimensionado (BROADBAND, 2006)

TV ativa são aplicativos independentes do conteúdo televisivo tradicional e não precisam especificamente de um vínculo com um programa. O foco do usuário, portanto, está na atividade em questão e a televisão é utilizada apenas como um novo suporte e outros meios poderiam ser utilizados, como o celular ou a web. Exemplos típicos desta categoria são envio de mensagens (email, mensagens SMS, etc.) (Figura 2-6), informações gerais (previsão do tempo, trânsito, notícias, horóscopo, etc.) (Figura 2-7), jogos e serviços de transa- 
ções e consultas (governo eletrônico, compras, banco, etc.). Esta categoria não tem uma denominação estabelecida na literatura e o termo TV ativa foi cunhado neste trabalho com a intenção de suprimir esta falta.

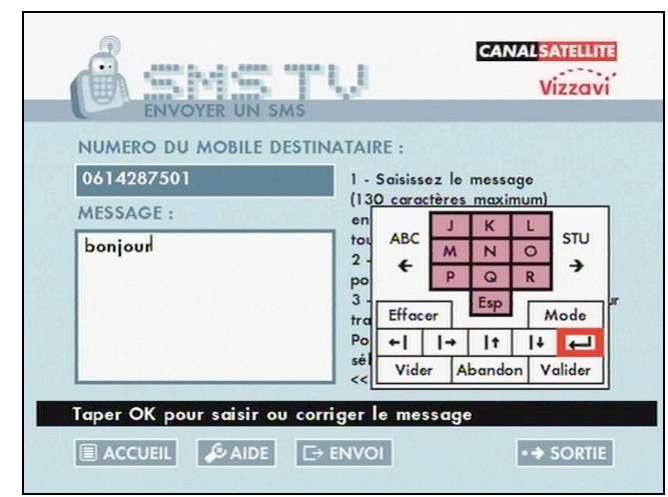

Figura 2-6 - Exemplo de aplicativo de TV ativa para envio de SMS (BROADBAND, 2006)

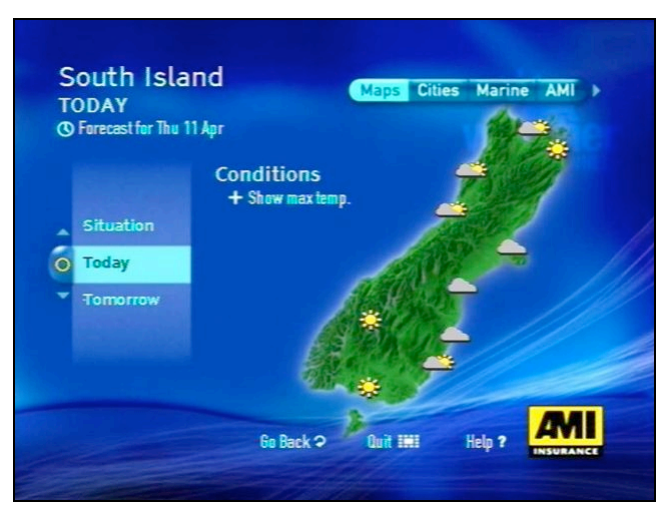

Figura 2-7 - Exemplo de aplicativo de TV ativa com previsão do tempo (BROADBAND, 2006)

A categoria de Infra-estrutura comporta aplicativos que permitem o usuário visualizar, organizar e controlar os conteúdos disponíveis em um terminal de acesso, mas que não são um objetivo final para o usuário. Exemplos desta categoria são o guia de programação (Figura 2-8), menus de navegação (Figura 2-9), assim como a configuração de parâmetros e preferências no terminal de acesso. O usuário não tem interesse em navegar pelos menus de um terminal de acesso, mas sim em utilizá-los para encontrar o conteúdo desejado, que é um programa de TV ou um aplicativo de TV ativa.

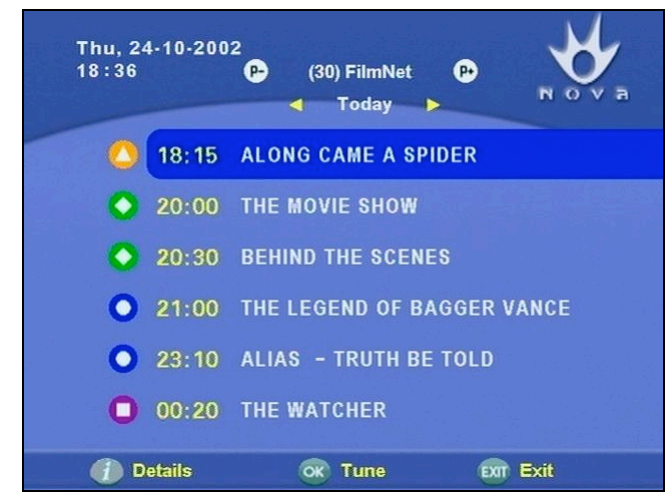

Figura 2-8 - Exemplo de guia de programação (BROADBAND, 2006)

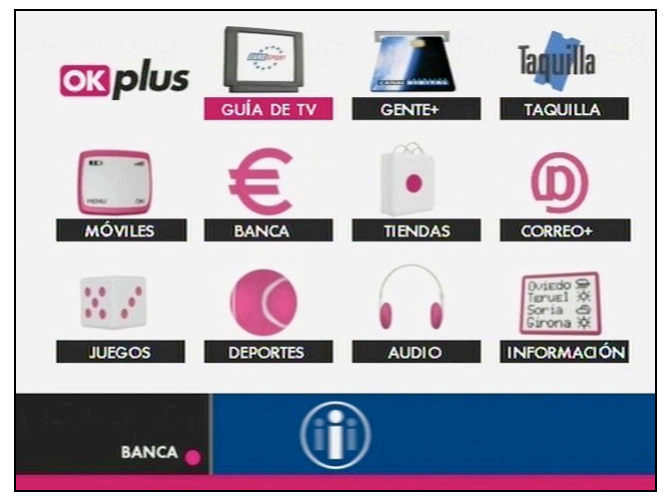

Figura 2-9 - Exemplo de menu de navegação (BROADBAND, 2006) 


\subsubsection{Usabilidade na TV Interativa}

Em dois artigos Nielsen (2004a; 2004b) descreve a baixa usabilidade encontrada em muitos produtos de eletrônica de consumo como controles remotos para TVs, videocassetes e tocadores de DVD. Spinellis (2003) afirma que o problema mais importante nestes equipamentos é a interface com o usuário. Ele afirma que a falta de padronização e a replicação de funcionalidades semelhantes em diversos aparelhos torna o sistema excessivamente complexo e também fornece exemplos de interfaces com o usuário que não seguem princípios de design centrado no usuário e desrespeitam diretrizes básicas de design de interfaces. Költringer et al. (2005) também fazem observações semelhantes sobre a falta de padronização e a dificuldade de uso em menus de DVDs. Estas evidências demonstram que diversos equipamentos deste tipo apresentam grandes problemas de usabilidade.

A situação não é diferente no caso da TVi. Em um estudo sobre a percepção de facilidade de uso da TVi, ela foi considerada mais difícil de usar do que um computador ou um carro (FREEMAN; LESSITER, 2001, p. 3), enquanto a TV tradicional foi considerada praticamente tão fácil de usar quanto um secador de cabelos. Outro estudo no Reino Unido indica que existem problemas de usabilidade em todas as partes dos sistemas de TVi, desde o controle remoto até as interfaces de programas de TVe (KLEIN; KARGER; SINCLAIR, 2003). Pesquisas em usabilidade de interfaces para TVi realizadas em outros países também trazem resultados semelhantes. Em Portugal a dificuldade de uso foi apontada como um dos grandes motivos pelos quais os usuários não experimentam os serviços interativos (QUICO; DAMÁSIO, 2004). Já na Suécia, Hedman (2002) demonstra que a falta de padronização entre os controles remotos gera problemas de usabilidade.

Considerando que a TV é voltada para atividades de lazer e descontração, o simples fato do usuário supor que a interface é difícil pode ser um fator impeditivo para o seu uso (FREEMAN; LESSITER, 2001, p. 20).

Baseado nos dados apresentados, é possível concluir que apesar da TVi abrir um grande leque de novas possibilidades ela apresenta muitos problemas de usabilidade, que podem chegar a impedir a sua utilização plena. Concordamos com Freeman e Lessiter (2003, tradução do autor), que dizem: “Os 
benefícios em potencial que a TV digital pode trazer [...] não se efetivarão se o equipamento e os serviços de TV digital não forem fáceis de usar, e percebidos como tal".

\subsubsection{Consistência na TV Interativa}

Nos estudos sobre TVi a falta de consistência é um dos problemas de usabilidade mais citados. Gawlinski (2003, p. 213, tradução do autor) oferece um panorama da situação que ocorre no Reino Unido, um dos países pioneiros no uso da TVi.

“Em um mundo ideal, todos os aplicativos interativos utilizariam o mesmo modelo de navegação. Espectadores não precisariam passar por um processo de aprendizagem cada vez que utilizam um novo serviço de TV interativa. Parte do sucesso da TV analógica vem do fato de que os serviços todos [do teletexto] funcionam de um modo apenas - através de um sistema de páginas e de menus hierárquicos.

Infelizmente, no Reino Unido, apesar de diversas associações de indústrias terem tentado, existe pouco consenso sobre como seria um modelo de navegação consistente para TV interativa. Cada produtor parece pensar que o seu modelo é o melhor. Aplicativos de TV interativa são tão variados que é difícil criar regras genéricas e praticáveis."

O impacto negativo da falta de consistência na TVi é ressaltada por vários outros autores (KLEIN; KARGER; SINCLAIR, 2003; IPSOS, 2005; BONNICI, 2003; LU, 2005; CHORIANOPOULOS, 2004) e uma análise das interfaces de TVi que existem em outros países confirma este fato.

Os exemplos apresentados da Figura 2-10 à Figura 2-13 (BROADBAND, 2006) demonstram quatro interfaces que poderiam ser acessadas sucessivamente por um mesmo usuário, pois pertencem a quatro programas de uma mesma plataforma de TV digital (a plataforma SKY no Reino Unido). 


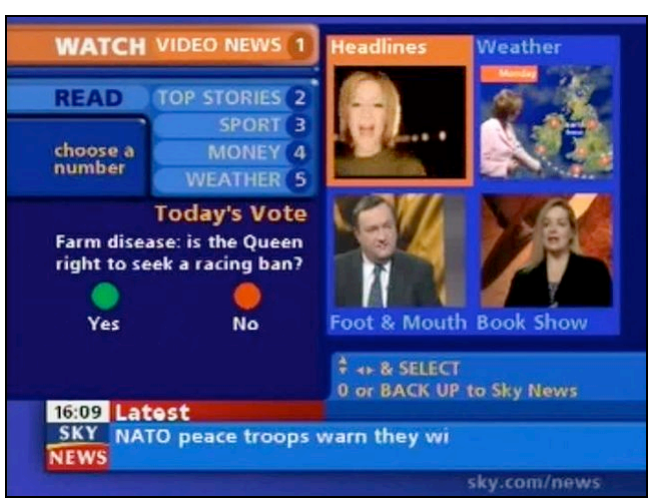

Figura 2-10 - Interface de programa do canal SKY News (BROADBAND, 2006)

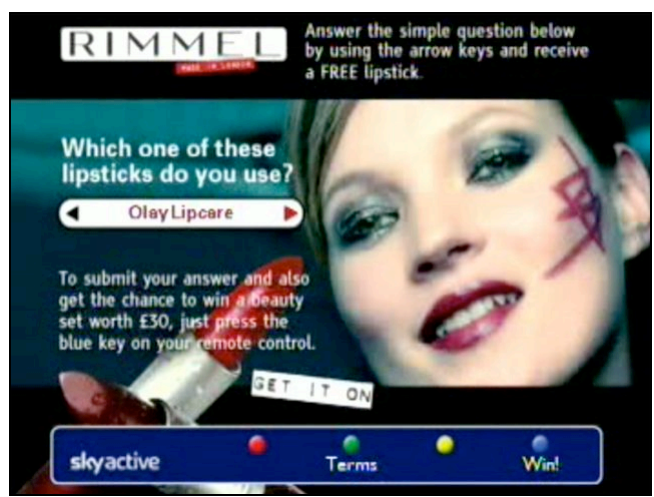

Figura 2-12 - Interface em comercial na plataforma SKY (BROADBAND, 2006)

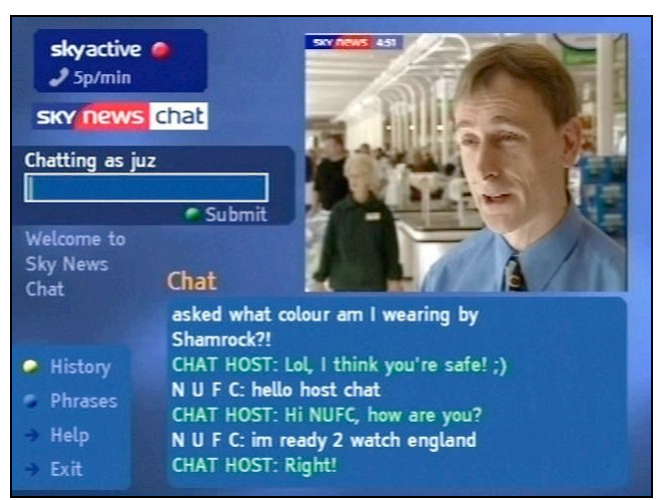

Figura 2-11 - Interface de outro programa do canal SKY News (BROADBAND, 2006)

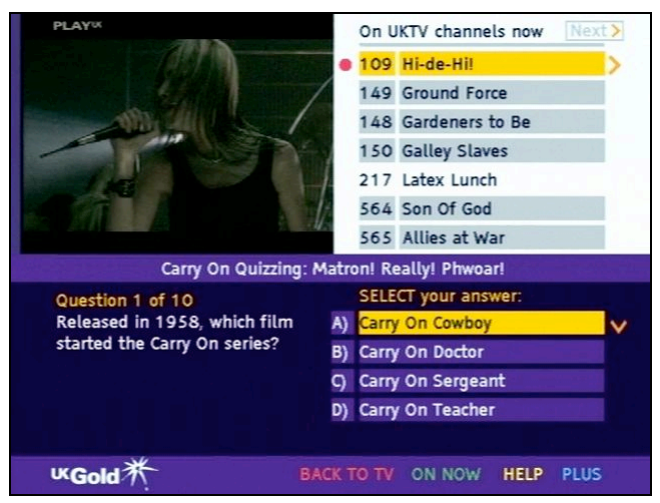

Figura 2-13 - Interface em outro canal da plataforma SKY (BROADBAND, 2006)

Na Figura 2-10 as teclas numéricas de 1 a 5 são utilizadas para navegação entre notícias, as teclas verde e vermelha para uma votação, as teclas direcionais para selecionar o vídeo e a tecla numérica 0 ou a tecla Back Up para voltar para o vídeo em tela inteira. Na Figura 2-11 a tecla vermelha está na tela mas não fica claro qual sua função, talvez conectar e desconectar, a tecla verde é utilizada para enviar o texto digitado, as teclas amarela e azul são atalhos para funções que também são acessíveis com as setas direcionais e a tecla de confirmação. Na Figura 2-12 as setas horizontais são utilizadas para escolher uma das opções disponíveis, a tecla verde para saber as condições da promoção e a tecla azul para enviar a resposta. Na Figura 2-13 as setas verticais são utilizadas para fazer a seleção em duas listas separadas e independentes, a 
lista superior (de canais) e inferior (de respostas), sendo que a confirmação na lista superior é feita com a tecla vermelha e na lista inferior com a tecla de confirmação. Não só o arranjo visual, mas também a forma de navegação, as funções dos botões e as funcionalidades disponíveis são completamente diferentes, e portanto não é difícil prever que os usuários tenham problemas.

Isto acontece em parte porque as interfaces de TVi são feitas por atores distintos. A interface do terminal de acesso, ou seja, o controle remoto e aplicativos de infra-estrutura, estão sob controle do fabricante do terminal de acesso. As interfaces de programas de TVe são feitas pelos produtores de conteúdo, que podem ser um produtor de conteúdo independente, uma emissora ou uma agência de publicidade. Por fim, as interfaces de aplicativos de TV ativa são feitas por empresas de desenvolvimento de software.

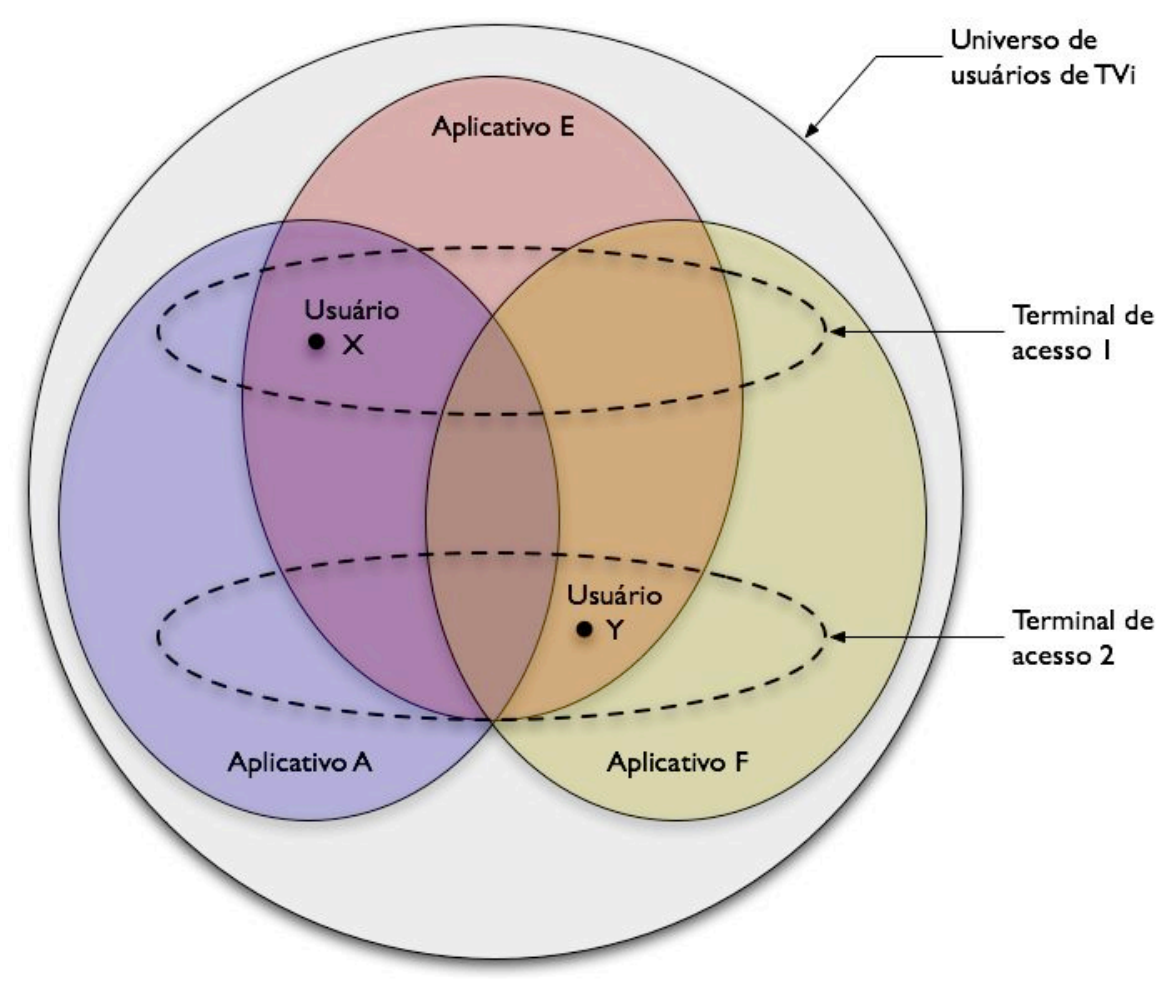

Figura 2-14 - Diagrama de exemplo da relação entre usuários, terminais de acesso e aplicativos

Na Figura 2-14 temos um exemplo do cenário que deve acontecer com a TVi. Neste exemplo o usuário X utiliza as interfaces do terminal de acesso 1 , do aplicativo A e do aplicativo E. O usuário Y utiliza as interfaces do terminal de acesso 2, do aplicativo F e do aplicativo E. Desta forma, para o usuário é 
importante que existam dois níveis de consistência, interna e externa. A consistência interna significa que cada uma das interfaces (do terminal de acesso e dos aplicativos) deve ser consistente consigo mesma, ou seja, que as teclas do controle remoto estejam de acordo com as telas nos aplicativos de infraestrutura e que as telas do aplicativo A sejam consistentes entre si. A consistência externa significa que os aplicativos devem ser consistentes entre si, ou seja, que para o usuário $X$ a interface do terminal de acesso 1 e dos aplicativos A e E sejam consistentes. Uma vez que o usuário Y também utiliza o aplicativo E, também deve existir um nível de consistência entre as interfaces que o usuário X e o usuário Y utilizam.

Um aspecto específico de consistência entre terminais de acesso é a questão de um conjunto mínimo de teclas que deve existir em todos os controles remotos. Hedman (2002) explica que a falta de botões universalmente disponíveis (entre equipamentos) é prejudicial para os desenvolvedores e que estes acabam sendo forçados a utilizar associações dissonantes entre as teclas do controle remoto e de elementos de tela. Esta associação ruim, por sua vez, prejudica a usabilidade das interfaces e tem impacto no usuário final. Esta falta de padronização entre controles remotos é bastante relatada na literatura (KLEIN; KARGER; SINCLAIR, 2003; IPSOS, 2005; BONNICI, 2003; LU, 2005; CAREY, 1996b; FREEMAN; LESSITER, 2003) e é bem exemplificada no guia de estilo da BBC (BBC, 2002, tradução do autor), que faz uma afirmação muito parecida com a citação anterior de Gawlinski (2003, p. 213).

\footnotetext{
“Em um mundo ideal todos os espectadores teriam os mesmos controles remotos e as interfaces poderiam desenvolver uma linguagem visual padronizada. No entanto, controles remotos são muito diferentes entre plataformas - e muitas vezes na mesma plataforma. $\mathrm{O}$ arranjo e rotulação de teclas pode variar, ou teclas podem simplesmente não existir."
}

Para o usuário, no entanto, todas estas interfaces são percebidas em conjunto, compondo uma experiência única. Portanto as interfaces que poderiam ser consistentes se consideradas de forma separada formam um grande conjunto de telas, botões e teclas no controle remoto sem coordenação entre eles. Como uma das conclusões de seu trabalho, Klein, Karger e Sinclair (2003, p. 4) 
enfatizam a necessidade de um enfoque unificado para o design das diversas interfaces de TVi, ou seja, um enfoque que leve em consideração as diversas interfaces a que o usuário pode ter acesso na TVi e não apenas as consistência interna de cada aplicativo.

Acreditamos que este enfoque unificado seja o principal fator para a conquista de uma maior consistência entre as interfaces, e que esta, por sua vez, seja um dos principais elementos para uma melhoria da usabilidade da TVi. 
Capítulo 3 - Metodologia para a Seleção de Boas Práticas de Interfaces 
Neste capítulo apresentamos uma visão detalhada da metodologia utilizada neste trabalho. O capítulo está divido nas cinco etapas que compõem a metodologia: modelagem de usuário, análise de tarefa, diretrizes gerais de interface, análise comparativa e coordenação de interface. A Figura 3-1 apresenta um diagrama da metodologia adotada.

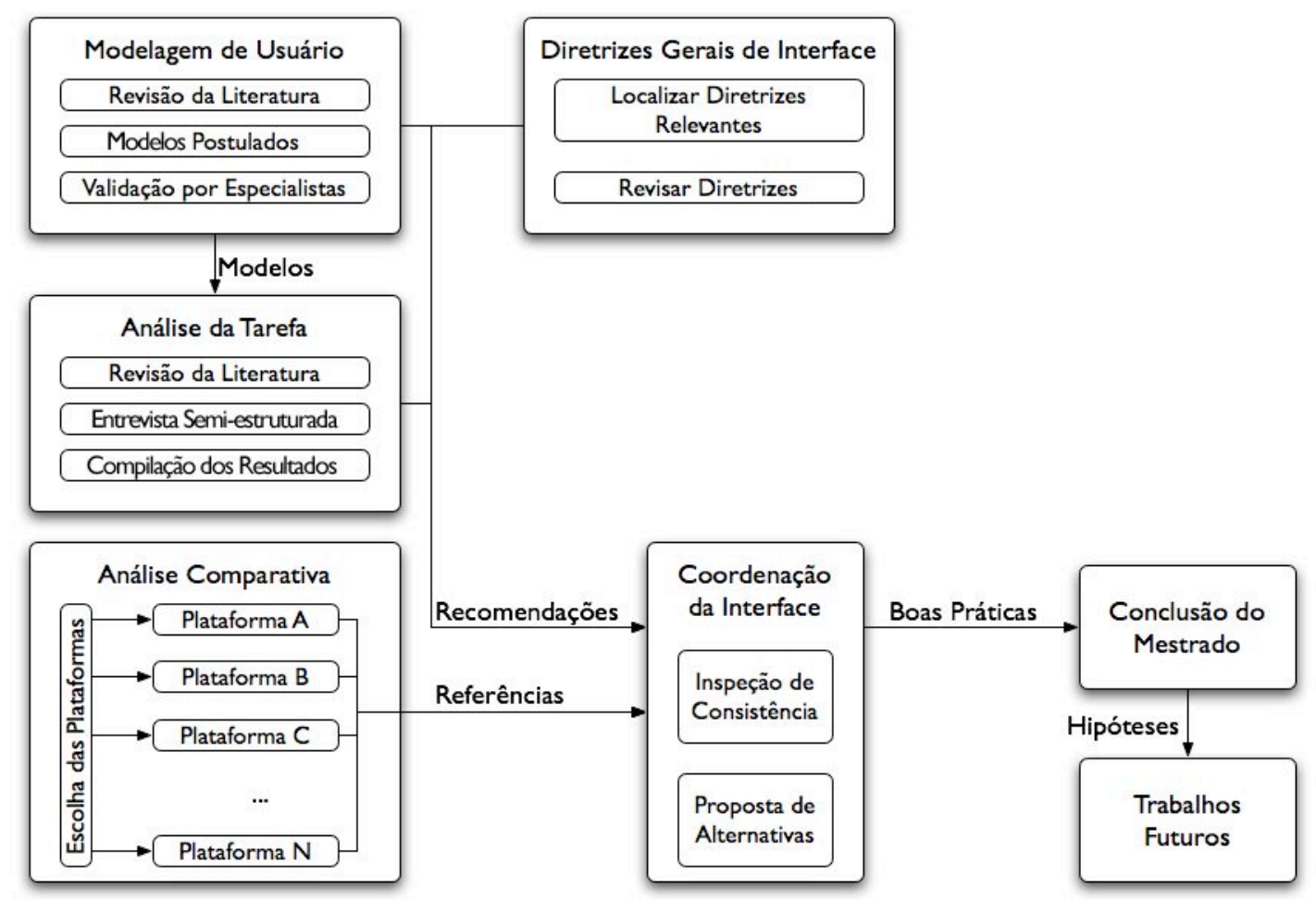

Figura 3-1 - Diagrama completo da metodologia adotada

A metodologia visa atingir o objetivo descrito no item 1.1, de encontrar, e se necessário propor, exemplos de interfaces de TVi que sejam adequadas e consistentes. Desta forma, as três primeiras etapas da metodologia geram recomendações que são utilizadas para a seleção de interfaces adequadas a este contexto. A etapa de análise comparativa busca exemplos de interfaces para serem utilizados como referências. A etapa de coordenação da interface utiliza as recomendações para selecionar, dentre as referências encontradas, bons 
exemplos de TVi e verificar consistência entre eles. Caso não sejam encontrados exemplos adequados e consistentes, esta etapa também propõe alternativas que satisfaçam estas condições.

\subsection{Modelagem de Usuário}

O objetivo desta etapa é compreender os usuários de um sistema por meio de modelos que buscam salientar os aspectos estruturais e os padrões recorrentes e descartar o que é menos importante (COOPER; REIMANN, 2003, p. 55). Utilizamos como referência uma das metodologias propostas por Mayhew (1999, p. 43), que propõe que os dados sejam coletados em entrevistas com especialistas ao invés de pesquisas diretas com os usuários finais. Estes dados são então interpretados e deles são extraídos os requisitos.

A partir de uma revisão da literatura, foram extraídos e comparados classificações e modelos de usuários utilizados em outros países (CAREY, 1996b; MAYER, 2003; QUICO; DAMÁSIO, 2004; NIEMINEN-SUNDELL; VÄÄNÄNEN-VAINIO-MATTILA, 2003). Os dados encontrados não foram, no entanto, suficientes pela falta de informações aplicáveis ao público brasileiro e pela falta de modelos detalhados para populações mais reticentes à adoção de novas tecnologias, um público crítico para a TV interativa no Brasil.

Foram utilizadas, então, fontes secundárias de informação sobre este público para obtenção de mais detalhes (KLEIN; KARGER; SINCLAIR, 2003; O'BRIEN et al., 1999; FREEMAN; LESSITER, 2003; TAYLOR; HARPER, 2003; IBGE, 2004; CPQD, 2004; INSTITUTO PAULO MONTENEGRO, 2005). Levou-se em consideração o fato de que dados levantados com outros objetivos (marketing, tecnologia, etc.) têm uma aplicação limitada como fonte de requisitos para usabilidade (BEYER; HOLTZBLATT, 1997, p. 32).

A partir da compilação dos dados, foram criados quatro modelos postulados, dois a partir dos modelos existentes e dois com base em fontes secundárias. Além disso, as soluções buscadas devem ser aplicáveis a quaisquer aplicativos de TVi, uma vez que o público-alvo deste trabalho é toda a população de possíveis usuários de TVi no Brasil, ou seja, quase a toda a população 
brasileira. Por este motivo, a escolha dos modelos de usuário postulados procurou ser o mais abrangente possível.

A partir dos modelos postulados, foi preparado um questionário levando em conta cinco categorias de características: conhecimento e experiência, hábitos de uso e tarefas, características físicas, características psicológicas e contexto social. Este questionário foi então aplicado a especialistas.

Os especialistas entrevistados foram os seguintes:

- Prof. Dr. da ECA-USP, com atuação nas áreas de Rádio, Televisão e Mídias Digitais, incluindo TV interativa.

- Coordenador de Produtos Multimídia de um grande fabricante de produtos eletro-eletrônicos, com grande conhecimento do público e do mercado de televisores no Brasil.

- Gerente de Serviços Interativos de uma operadora de TV por assinatura, com grande conhecimento do público de TV paga e das possibilidades da TV interativa.

O critério mais importante e fundamental para a seleção de especialistas foi um bom conhecimento do público objeto de estudo, ou seja, usuários de TV no Brasil. Um segundo critério foi o conhecimento da TV interativa, suas possibilidades e características. Este critério não foi imprescindível mas teve um impacto positivo na qualidade das respostas. Não foram critérios importantes para a seleção de especialistas o conhecimento de usabilidade, de design de interface e da tecnologia da TV interativa.

As respostas dos especialistas foram tabuladas para se extrair os dados relevantes de cada modelo. A partir destes foram criados os modelos de usuário validados, que são os modelos postulados modificados em função das informações extraídas da tabulação. Durante a revisão da literatura foram encontradas diversas características de usuários válidas para usuários de TVi de forma geral (GAWLINSKI, 2003; DALY-JONES, 2003; NORMAN, 1990; CPQD, 2004; CAREY, 1996b; LU, 2005). Estas informações também foram úteis nesta etapa do processo, como características gerais válidas para qualquer usuário de TVi. 
A partir das características dos modelos validados e das características gerais foram extraídos os requisitos de usabilidade mais importantes para esta população de usuários. Os requisitos estabelecidos nesta etapa foram utilizados na coordenação da interface para a escolha das soluções mais adequadas. Também utilizamos os modelos de usuário validados como um parâmetro importante na etapa posterior de análise de tarefa.

\subsection{Análise de Tarefa}

Além de compreender as características dos usuários, para obter uma boa usabilidade em um sistema é necessário também compreender suas tarefas e o contexto onde ocorrem (ISO, 1998). Este é o objetivo desta etapa do trabalho.

A metodologia propostas por Mayhew (1999, p. 74) foi utilizada como referência. Esta metodologia propõe uma série de passos que se iniciam com a identificação de usuários e tarefas mais importantes no sistema. O passo seguinte é a observação ou entrevista dos usuários em contexto, ou seja, no seu ambiente de uso quotidiano, realizando as tarefas elencadas no passo anterior. Este passo permite a compreensão da maneira como as tarefas são realizadas e quais as motivações do usuário para a escolha de uma determinada forma de realizá-las.

Os dados coletados nesta observação ou entrevista são compilados na etapa seguinte, que consolida a análise das tarefas. A partir desta análise é possível extrair as recomendações que serão utilizadas na etapa de coordenação da interface (item 3.5).

O critério de seleção dos usuários para esta etapa do trabalho foi baseado nos modelos de usuários encontrados na etapa anterior. A determinação das tarefas mais importantes foi feita através de uma revisão da literatura. Dois trabalhos feitos no Reino Unido puderam ser utilizados como referência (KLEIN; KARGER; SINCLAIR, 2003; TAYLOR; HARPER, 2003).

O primeiro estudo (TAYLOR; HARPER, 2003) elenca 5 atividades mais importantes, que utiliza no levantamento de dados. São elas:

- Ver TV 
- Obter Informação sobre a Programação

- Navegar pelo Sistema (TV e TVi)

- Selecionar Programas

- Usar e Guardar Vídeos

Este estudo foi feito para servir como base para o desenvolvimento de uma interface de Personal Video Recorder (PVR), daí o interesse no uso de fitas de vídeo para reproduzir e gravar programas. Como esta não é uma preocupação específica deste estudo esta tarefa foi excluída.

O segundo estudo (KLEIN; KARGER; SINCLAIR, 2003) utilizou 8 tarefas que englobam tanto o uso mais simples do aparelho quanto o uso de funcionalidades mais avançadas. As atividades elencadas são:

- Ligar e Desligar o Equipamento

- Selecionar Conteúdo e Trocar de Canal

- Ajustar o Volume

- Usar Teletexto Digital (avançado)

- Usar Aplicativos de TVi (avançado)

- Controle de Legendas (avançado)

- Canais Favoritos (avançado)

- Ajustar as Configurações (avançado)

Como o sistema de Teletexto não é utilizado no Brasil esta atividade foi excluída. O controle de legendas também foi expandido para incluir o uso de áudio alternativo, tarefa que provavelmente não é importante no contexto do Reino Unido.

Assim, com base nestas duas listas de atividades foi feita uma lista adequada a esta pesquisa. Foi incluída na lista a tarefa de obter ajuda, que não está presente em nenhuma das listas, pois por meio dela é possível saber como o usuário trata situações de erros e problemas no sistema.

Desta forma a lista de tarefas utilizada neste trabalho foi portanto:

- Ligar e Desligar o Equipamento

- Selecionar Conteúdo e Trocar de Canal

- Ajustar o Volume

- Trocar Legenda e Áudio Alternativo 
- Usar Aplicativos de TVi

- Ajustar as Configurações

- Obter Ajuda

A próxima questão metodológica foi o formato utilizado para coleta dos dados. Seguindo novamente a metodologia proposta por Mayhew (1999, p. 86) foram feitas entrevistas semi-estruturadas. Nestas entrevistas existe um roteiro pré-definido, mas como o objetivo é justamente compreender as atividades em seus detalhes e variantes, este roteiro serve apenas como base e precisa ser adaptado durante a entrevista de acordo com as informações que vão surgindo.

Por exemplo, no roteiro pode haver um item que pergunta sobre como o usuário utiliza legendas e áudio alternativo. O usuário pode responder que não utiliza estas funcionalidades, então é necessário saber porque ele não as utiliza, se é porque não sabe que existem, ou porque é muito difícil utilizá-las, ou simplesmente porque não vê utilidade nelas. Desta forma, o roteiro serve como uma linha-mestra para a entrevista, mas deve dar espaço para adaptações.

Nestas entrevistas também é utilizado o modelo mestre-aprendiz, onde o usuário é o conhecedor das tarefas (mestre) e o entrevistador está buscando aprender como estas tarefas são feitas e por quê (aprendiz). As entrevistas são feitas no ambiente normal de uso e procura-se respeitar ao máximo os horários em que estas tarefas são feitas regularmente.

O número de usuários entrevistados neste trabalho (três usuários por modelo) estava dentro do mínimo recomendado por Mayhew (1999). Foram entrevistados usuários de dois dos quatro modelos elencados: Torcedor Antenado e Mãe Ocupada. Não foram entrevistados usuários dos modelos de Meia Idade com Ajuda e Torcedor com Baixa Alfabetização. Esta escolha foi feita para priorizar a obtenção de dados mais detalhados de dois modelos apenas, ao invés de um número menor de usuários por modelo, mas utilizando todos os modelos.

Não existia um pré-requisito sobre o sistema de TV (aberta ou paga, analógica ou digital, cabo ou satélite) que estes usuários deveriam ter, mas a dis- 
tribuição que ocorreu foi bastante proveitosa, pois cada um dos modelos teve um usuário com TV analógica, um com TV digital e um com PVR, o que permitiu observar algumas variações de atividades entre as plataformas. Não havia nenhum usuário que tivesse apenas TV aberta.

Neste trabalho os usuários do modelo de Torcedor Antenado foram chamados de TA1, TA2 e TA3, enquanto os usuários do modelo de Mãe Ocupada foram MO1, MO2 e MO3. Na Tabela 3-1 encontra-se a relação entre os usuários entrevistados e os respectivos sistemas de TV.

Tabela 3-1 - Relação entre usuários entrevistados e sistema de TV utilizado

\begin{tabular}{|l|l|l|}
\hline & Torcedor Antenado & Mãe Ocupada \\
\hline TV Analógica (cabo) & TA1 & MO1 \\
\hline TV Digital & TA2 & MO2 \\
\hline TV Digital com PVR & TA3 & MO3 \\
\hline
\end{tabular}

Considerando que a entrevista foi feita na residência dos usuários e eventualmente na área íntima da residência (quarto) foi decidido realizar as entrevistas com um entrevistador apenas. Como o entrevistador teria que conduzir a entrevista e ao mesmo tempo coletar dados optou-se pela gravação em vídeo da entrevista. Para minimizar o impacto inicial negativo (os usuários se sentem menos à vontade) procurou-se posicionar a câmera em um local que ficasse fora do foco de atenção e uma vez ligada ela não era manuseada até o final da entrevista. Desta forma em pouco tempo os usuários ficaram mais à vontade e o impacto de estarem sendo filmados foi bastante reduzido. Por questões éticas, todos os usuários estavam plenamente cientes de que estavam sendo filmados e deram permissão escrita para a filmagem.

As entrevistas duraram entre uma hora e uma hora e meia (limite de tempo da fita na câmera). Após a entrevista, a gravação era assistida novamente para anotações complementares. O tempo necessário para rever as gravações foi maior, entre uma vez e meia e duas vezes o tempo da entrevista. 
O primeiro dado extraído destas entrevistas foi uma análise do ambiente, sendo ressaltados aspectos de contexto das atividades. Estes dados estão apresentados no item 4.2.1.

Das anotações foram extraídos os dados mais importantes referentes às sete tarefas elencadas, que foram compilados por ordem de atividade. As atividades dos dois modelos estudados foram inicialmente tratadas separadamente, mas para a extração das recomendações destas atividades foi mais apropriada a consideração dos dois grupos de usuários em conjunto. Estes dados estão apresentados no item 4.2.2.

\subsection{Diretrizes Gerais de Interface}

Diretrizes de interface são regras e princípios documentados na literatura e que podem ser utilizados como orientação no processo de avaliação e design de uma interface.

Uma busca por diretrizes relativas à TV interativa levou-nos a seis publicações de grande relevância, listadas a seguir:

- BBCi Interactive Television Style Guide (BBC, 2002)

- A Guide for Digital TV Service Producers (ARVID, 2004)

- Interactive Television Design Guide (LIBERATE, 2002)

- Tiresias.org Television Guidelines (TIRESIAS, 2006)

- Interactive Television Production (GAWLINSKI, 2003)

- Case Study: The Usability of Electronic Programme Guides (DALY-JONES, 2003)

Estas diretrizes foram revisadas e foram selecionadas as recomendações que se aplicam de forma mais abrangente à TV interativa. Isto foi necessário pois algumas destas publicações são relativas à uma emissora (BBC), um país (Finlândia) ou uma plataforma de TV interativa (Liberate), e apresentam recomendações que não são universalmente aplicáveis.

As recomendações selecionadas foram organizadas em três grupos:

- Design para TV

- Navegação 
- Dispositivos de Interação

\subsection{Análise Comparativa}

A análise comparativa é uma revisão crítica de diversas interfaces que busca perceber os diferentes enfoques possíveis para a resolução dos problemas de design de um contexto específico (NIELSEN, 1994). Esta análise serve como referência para novas idéias e para verificar quais enfoques são mais indicados e quais devem ser evitados.

Para esta etapa do trabalho inicialmente foram elencados aspectos específicos das interfaces e posteriormente foi feita a análise de cada um destes aspectos nas interfaces escolhidas (BENINI; BATISTA; ZUFFO, 2005). Foram escolhidas as seguintes plataformas: TV aberta, TV a cabo analógica, DirecTV, TVA Digital, NET Digital, SKY e SKY+. Utilizamos o termo plataforma para definir o conjunto de interfaces que compõe cada um destes sistemas, assim como sua infra-estrutura. O critério mais importante para a escolha das plataformas foi o de acesso físico, para permitir uma análise direta das interfaces da plataforma. As duas plataformas de TV analógica (TV aberta e TV a cabo analógica) foram selecionados para servirem como um referencial comparativo dos sistemas mais utilizados atualmente e as cinco plataformas restantes são as plataformas de TV digital existentes no Brasil.

Os aspectos específicos de interesse para a comparação não eram conhecidos a priori, portanto foi realizada uma primeira análise mais abrangente de três das plataformas (TV a cabo analógica, TVA Digital e SKY). Desta análise inicial extraímos os aspectos mais importantes para a análise comparativa, que são os seguintes:

- Mapa de Navegação: diagrama que mostra as diversas partes que compõem o sistema e a navegação principal entre elas. Foram utilizados como referência os high-level blueprints (ROSENFELD; MORVILLE, 2002);

- Telas Principais: decomposição estrutural das telas principais da plataforma, que procura evidenciar seus componentes. Foram selecionadas 4 telas especificamente:

- Tela de TV: a tela de TV com as tarjas de informação, sinopse, etc.; 
- Tela inicial: a primeira tela que aparece ao ligar o aparelho;

- Guia de programação: tela que mostra a programação dos diversos canais por horário;

- Aplicativos de TV ativa: telas de aplicativos de TV ativa que estejam disponíveis na plataforma;

- Dispositivo de Interação: apresenta o dispositivo de interação principal, o controle remoto e outros acessórios físicos do sistema (guia de programação impresso, etc.);

- Navegação: diagrama que mostra a navegação realizada para a execução de algumas tarefas dentro de um contexto específico. Foram utilizados como referência os diagramas baseados em tarefas (task-oriented blueprints) (ROSENFELD; MORVILLE, 2002) e os contextos e tarefas escolhidos foram:

- TV: navegar entre canais, ver programação atual, ver programação em outro canal e horário, ver sinopse do programa atual, ativar opções de legenda e áudio alternativo;

- Guia de programação: ver programação atual, ver programação em outro canal e horário, ver sinopse do programa selecionado;

- Tela inicial: navegar pela tela inicial, ir para TV, ir para guia de programação;

- Aplicativo de TV ativa: navegar pelo aplicativo, utilizar funções disponíveis.

A partir destes pontos foi elaborado um roteiro de análise para a sistematizar a coleta de informações. Seguindo este roteiro, a plataforma foi utilizada ao mesmo tempo em que se faziam anotações de uso e uma filmagem da interação para referência futura. Utilizando as anotações e a filmagem realizada foram feitas as análises em um nível de detalhamento adequado, ou seja, as telas foram selecionadas e os diagramas elaborados. Como o enfoque desta etapa foi a comparação entre as interfaces, os diagramas procuram manter a mesma estrutura visual para evidenciar as diferenças.

Para simplificar a análise foi adotada uma convenção de nomenclatura, tecla sendo sempre o interruptor no controle remoto e botão sendo sempre um objeto clicável na interface gráfica. 


\subsection{Coordenação da Interface}

A coordenação da interface é a etapa sugerida por Nielsen (1994) para verificar a consistência das diversas partes da interface de um sistema. Para tal, neste trabalho foi feita uma inspeção de consistência (SHNEIDERMAN, 1998) entre as diversas plataformas analisadas, que geraram tabelas comparativas entre as soluções encontradas. A estrutura utilizada para a inspeção de consistência foi baseada nos pontos utilizados na análise comparativa.

Na etapa seguinte foi feita uma proposta de modificações nas interfaces para solucionar as inconsistências, tanto entre plataformas quanto entre as diversas partes da interface. Esta proposta utilizou como parâmetros as recomendações extraídas das etapas iniciais desta metodologia (itens 3.1, 3.2 e 3.3). Estas recomendações também foram utilizadas para uma análise crítica das soluções encontradas nas outras plataformas e para a verificação de sua adequação. Nos casos onde as interfaces encontradas não se mostravam adequadas, foram elaboradas novas alternativas.

O processo de inspeção de consistência foi realizado de forma iterativa à medida que as propostas eram elaboradas, procurando-se assim garantir a consistência do sistema proposto nos diversos níveis de sua interface. 


\section{Capítulo 4 - Aspectos Experimentais da Metodologia Proposta}

“A maioria dos programas de televisão, à exceção dos eventos esportivos e dos resultados de uma eleição, não precisa ser transmitida em tempo real, [...]. E, mais importante, uma vez no computador, não há necessidade de vê-los na ordem em que foram enviados. De repente, a TV se transforma num veículo de acesso aleatório, mais parecido com um livro ou jornal: pode-se folheá-la, modificá-la; ela não depende mais do horário, do dia ou do tempo necessário para a transmissão.

Se pararmos de pensar no futuro da televisão em termos exclusivamente de alta definição e começarmos a construí-lo em sua forma mais geral - a da irradiação de bits -, a TV se transformará num veículo inteiramente diferente. Começaremos, então, a testemunhar o surgimento de muitos aplicativos novos, criativos e estimulantes na superestrada da informação." ${ }^{4}$

${ }^{4}$ NEGROPONTE, N. A Vida Digital, São Paulo: Companhia das Letras, 1995. 231 p. 
Neste capítulo apresentamos os principais resultados deste trabalho. $\mathrm{O}$ capítulo segue a estrutura exposta no capítulo anterior, que se baseia nas cinco etapas de desenvolvimento desta dissertação.

\subsection{Modelagem de Usuário}

Quatro classificações encontradas na revisão da literatura foram utilizadas como base.

A primeira classificação separa os usuários de acordo com sua postura em relação à tecnologia (NIEMINEN-SUNDELL; VÄÄNÄNEN-VAINIOMATTILA, 2003). É uma classificação freqüentemente utilizada para dispositivos eletrônicos de consumo de massa, como celulares, aparelhos de DVD e TV interativa (MAYER, 2003; GAWLINSKI, 2003) e apresenta as seguintes categorias:

- Inovadores (innovators): os primeiros usuários a experimentar uma tecnologia, mais interessados na novidade do que no produto ou funcionalidade em si;

- Entusiastas (early adopter): estes usuários também são atraídos pela novidade, mas buscam algum benefício específico com a nova tecnologia;

- Maioria Inicial (early majority): são os usuários que adotam a tecnologia quando esta passa a ser mais aceita e ganha escala de mercado;

- Maioria Tardia (late majority): são os usuários que passam a utilizar a tecnologia quando esta já está consolidada, pois antes não viam motivo para sua adoção, ou encontravam algum impedimento para o seu uso;

- Retardatários (laggards): são os últimos usuários a adotar uma tecnologia, normalmente por falta de interesse ou aversão.

A segunda classificação é específica para usuários de TVi e foi criada por Quico e Damásio (2004) com base nos dados recolhidos através de dois estu- 
dos realizados em Portugal por uma operadora de TVi via cabo e satélite. Segundo esta classificação os usuários são divididos em quatro categorias:

- Curiosos Entusiastas: experimentam as novas funcionalidades da TVi, normalmente por tentativa e erro, têm entre 20 e 30 anos e sentem-se muito à vontade com a tecnologia;

- Curiosos Reticentes: também experimentam as novas funcionalidades por tentativa e erro, mas já estão em uma faixa etária entre 30 e 40 anos e, apesar de terem experiência e segurança ao lidar com a tecnologia, não apresentam o entusiasmo do grupo anterior;

- Medrosos com Orientação: estes usuários têm pouca familiaridade com a TVi e apresentam receio ou até aversão a novas tecnologias, mas ao encontrarem uma dificuldade buscam ajuda e procuram aprender a utilizála;

- Medrosos Desmotivados: assim como o grupo anterior, também têm pouca familiaridade com a TVi, mas seu receio é maior a ponto de procurarem utilizar meios já conhecidos (jornal, telefone) ou simplesmente desistirem de utilizar a TVi frente a um obstáculo.

A terceira classificação apresenta sete modelos de usuários de TVi do Reino Unido (MAYER, 2003; GAWLINSKI, 2003) com detalhes mais específicos sobre suas características físicas e psicológicas. A seguir apresentamos os modelos, dando ênfase aos mais importantes:

- Gadget Guy (homem dos aparelhos): são os típicos inovadores, dão mais atenção à novidade do que à utilidade da tecnologia em si;

- Armchair Athlete (atleta de poltrona): essencialmente masculino e adulto, adora esportes e seus times favoritos, gosta de estar no controle da situação;

- Generation i (geração i): adolescentes, com grande atividade social, muito interessados em novas tecnologias e com bastante auto-confiança em termos tecnológicos;

- Daytime Dabblers (errantes diurnas): essencialmente feminino e adulto, utilizam a televisão durante o dia, enquanto cuidam da casa, dos filhos, ou em intervalos entre atividades. Apresentam um padrão de uso bastante descompromissado e entrecortado com outras atividades; 
- Early Clicker: crianças com idade entre 3 e 10 anos, encaram a tecnologia com naturalidade, principalmente devido ao hábito de utilizarem computadores;

- i-Potato: essencialmente masculino e na faixa etária entre 30 e 55 anos. Passa o dia simplesmente mudando de canal, convencido de que sempre haverá de ter alguma coisa interessante na TV;

- Silver Sofas: usuários com mais de 50 anos, normalmente aposentados e com bastante tempo disponível. Têm uma certa proficiência com a tecnologia pois já a utilizaram no trabalho.

A quarta classificação foi extraída de um estudo etnográfico realizado por Carey (1996b) a partir de um teste piloto de TVi com 50 famílias durante 8 meses nos EUA. Esta classificação apresenta quatro modelos de usuários:

- High Users (usuários ativos): maioria masculina (mulheres são solteiras, aposentadas ou não têm crianças pequenas), utilizam bastante a televisão inclusive com horários reservados para isto, gostam de esportes e jogos (de TVi), têm interesse em atividades competitivas, na troca de mensagens (pela TVi) e em conhecer outros high users;

- Mulheres: tipicamente trabalham e cuidam dos filhos e portanto têm pouco tempo disponível. Utilizam a TV enquanto estão fazendo outras coisas (cuidando dos filhos ou da casa), freqüentemente utilizam um segundo aparelho de TV (na cozinha ou no quarto) e quando estão assistindo TV em grupo normalmente não ficam com o controle remoto (este fica com o marido);

- Adolescentes: em sua maioria se consideram high users apesar da falta de conteúdo voltado para eles. Têm muito interesse na troca de mensagens e sentem na TVi uma sensação de "lugar" onde eles "estão", como se estivessem passeando em um shopping-center;

- Crianças: Carey subdivide este grupo em várias faixas etárias. Cada faixa etária apresenta características específicas, em um nível de detalhe além do escopo deste trabalho.

Apesar destas quatro classificações terem sido feitas independentemente, em países e plataformas distintas, foi possível fazer uma comparação entre os seus modelos, apresentada na Tabela 4-1. 
Tabela 4-1 - Comparação entre as 4 classificações de usuários de TVi

\begin{tabular}{|l|l|l|l|}
\hline $\begin{array}{c}\text { Nieminen- } \\
\text { Sundell e } \\
\text { Väänänen- } \\
\text { Vainio-Mattile }\end{array}$ & \multicolumn{1}{|c|}{ Quico e Damásio } & \multicolumn{1}{|c|}{ Mayer } \\
\hline Inovadores & $\begin{array}{l}\text { Curiosos Entusias- } \\
\text { tas }\end{array}$ & Armchair Athlete & High Users \\
\cline { 2 - 4 } Entusiastas & Curiosos Reticentes & Daytime Dabblers & Mulheres \\
\cline { 2 - 5 } & $\begin{array}{l}\text { Maioria Inicial } \\
\text { entação }\end{array}$ & Early Clickers & Crianças \\
\hline Maioria Tardia & $\begin{array}{l}\text { Medrosos Desmoti- } \\
\text { vados }\end{array}$ & & \\
\hline Retardatários & & & \\
\hline
\end{tabular}

Nesta comparação foi possível constatar que dois modelos se destacam pela sua semelhança nos diversos estudos:

- masculino adulto, boa familiaridade com tecnologia, interesse em esportes e

- feminino adulto, sem aversão nem interesse pela tecnologia, com pouco tempo e atenção dividida.

Cada um destes dois modelos também representa uma categoria distinta, o que proporcionou uma boa distribuição geral. Por estes motivos foram criados modelos postulados a partir destes dois modelos para que fossem validados nas entrevistas com especialistas.

Também foi possível ver que as classificações Maioria Tardia e Retardatários não têm modelos de usuários com o nível de detalhamento encontrado para as outras classificações. Para a TV aberta no Brasil, estas duas classificações têm grande importância pois compreendem uma parcela significativa da 
população e são um público crítico, devido à sua falta de familiaridade ou até aversão a novas tecnologias. Com base em estudos sobre populações críticas em outros países (KLEIN; KARGER; SINCLAIR, 2003; IPSOS, 2005) e dados a respeito da população brasileira (IBGE, 2004; CPQD, 2004; INSTITUTO PAULO MONTENEGRO, 2005) mais dois modelos foram postulados, um para cada categoria faltante.

Os quatro modelos postulados, portanto, foram:

- Torcedor Antenado: adulto, essencialmente masculino, boa familiaridade com tecnologia e interesse específico em esportes;

- Mãe Ocupada: adulto, feminino, indiferença pela tecnologia e atenção dispersa entre muitas atividades;

- Meia Idade com Ajuda: acima de 50 anos, necessita óculos para curta distância, pouca familiaridade com a tecnologia mas possibilidade de ajuda de parente ou amigo;

- Torcedor com Baixa Alfabetização: adulto, essencialmente masculino, tem aversão à tecnologia e desiste caso encontre obstáculos.

Estes quatro modelos foram apresentados aos especialistas e foram considerados relevantes e representativos. Adolescentes e crianças também foram considerados importantes, mas em menor grau do que os quatro modelos escolhidos para este estudo.

A seguir os quatro modelos validados são apresentados levando também em consideração os dados coletados com os especialistas.

\subsubsection{Modelo Torcedor Antenado}

Este modelo considera um público essencialmente masculino, adulto, com boa escolaridade, boa familiaridade com a tecnologia e um interesse específico em esportes.

Procuram a TV para entretenimento com objetivo bem definido e alta motivação. Têm um perfil competitivo e gostam de se sentir no controle da situação. No caso brasileiro, este modelo pertence às classes sociais A e B. 
A proficiência com a tecnologia, familiaridade com o assunto e perfil controlador indicam uma interface rápida e eficiente.

O volume de informações pode ser grande e organizado em um esquema hierárquico de níveis e sub-níveis, eventualmente até em uma estrutura em rede.

Por outro lado, por estar ligado a uma atividade de relaxamento e descontração, a interface deve ser de fácil utilização e com processos simples.

\subsubsection{Modelo Mãe Ocupada}

Este modelo considera um público feminino, adulto, com boa escolaridade, sem interesse na tecnologia, com foco voltado para o conteúdo e atenção dispersa em múltiplas atividades simultâneas.

Quando estão assistindo à TV em grupo costumam assumir uma postura de usuários secundários, tanto com público masculino quanto infantil. No caso brasileiro, este modelo também pertence às classes sociais A e B.

O interesse dividido em diversas atividades demanda uma interface onde seja fácil a recuperação de tarefas interrompidas. Também são importantes informações sobre o estado atual do sistema (que canal é este, que tela é esta, o que posso fazer a partir da tela atual), para a usuária poder se orientar rapidamente.

O foco no conteúdo indica uma interface mais discreta, deixando o conteúdo em si em evidência.

\subsubsection{Modelo Meia Idade com Ajuda}

Este modelo considera um público com idade acima de 50 anos que apresenta uma certa insegurança frente à utilização de novas tecnologias, e prefere utilizar tecnologias já aprendidas.

No entanto, passa a utilizar novas tecnologias quando não tem outra opção ou quando apresentam alguma grande vantagem frente a tecnologias antigas. Nestes casos, para aprender a utilizar a nova tecnologia, ou quando en- 
contra alguma dificuldade, recorre a amigos, parentes ou a suporte técnico e procura solucionar o problema.

Uma vez que este usuário utiliza a interface baseado em procedimentos decorados, é fundamental que esta seja de fácil memorização. Também é fundamental que a interface seja estável, ou seja, que não se modifique ao longo do tempo, senão o usuário perderá o que foi aprendido.

O usuário já está acostumado à TV na forma existente hoje em dia e tem hábitos formados para sua utilização. A interface, portanto, deve ser o mais parecida possível com o que existe atualmente, com novas funcionalidades acrescidas ao sistema, mas sem modificar seu funcionamento básico.

Para este modelo também é muito útil um ponto de partida facilmente acessível na estrutura de navegação, para onde o usuário pode navegar caso encontre algum problema. Desta forma pode cancelar o processo atual e retomá-lo de um ponto de partida conhecido caso tenha uma dificuldade.

Devido à idade este público apresenta algum prejuízo na visão, que obriga à utilização de óculos para curta distância. Desta forma a interface também deve evitar que o usuário seja obrigado a alternar sua atenção entre a tela da TV e o controle remoto.

\subsubsection{Modelo Torcedor com Baixa Alfabetização}

Este modelo considera um público essencialmente masculino, adulto, com um interesse específico em esportes e alta motivação, mas baixa escolaridade e muito pouca familiaridade com a tecnologia. É um público contrastante com o Torcedor Antenado, pois tem interesses e objetivos similares, mas vê a tecnologia como um obstáculo e não um facilitador.

Para este público, definimos como baixa escolaridade um índice de alfabetização nível 1 ou menor (INSTITUTO PAULO MONTENEGRO, 2005), ou seja, o usuário não é alfabetizado ou consegue reconhecer algumas palavras bastante utilizadas como o próprio nome, uma linha de ônibus que utiliza muito ou um canal de TV que assiste freqüentemente. Esta classificação en- 
globa $40 \%$ da população brasileira (INSTITUTO PAULO MONTENEGRO, 2005). Este modelo pertence às classes sociais C, D e E.

Para este usuário a facilidade de aprendizagem e a facilidade de uso são fundamentais. Caso encontre dificuldades na interface esta pode se tornar uma barreira intransponível, impedindo o acesso à funcionalidade desejada.

Devido à baixa alfabetização a interface deve ter indicativos gráficos indiretos, como ícones, posição, cor e agrupamento para orientar o usuário. Uma outra alternativa possível é a utilização de ícones sonoros.

\subsubsection{Resultados para todos os Modelos}

Comparando os quatro modelos, dois resultados chamam a atenção. Em primeiro lugar existe uma grande diferença entre os modelos tanto em eficiência provável quanto em necessidades. Apesar disso, estes modelos poderão interagir entre si, pois é muito comum que assistir à TV seja uma atividade feita em grupo (CAREY, 1996b; GAWLINSKI, 2003; CPQD, 2004; CAREY, 1996b). Em segundo lugar, nos quatro modelos validados os usuários gostam da TV e fazem um uso intenso da mesma. O menor tempo de uso estimado por modelo foi de 1 hora por dia e o máximo de 5 horas, concentrados no período noturno e nos finais de semana.

Abaixo serão apresentados resultados que se aplicam ao público de TV em geral mas que não são específicos dos modelos selecionados e foram obtidos através da revisão da literatura e das entrevistas com especialistas. A postura do usuário quando utiliza a TV é relaxada e mais passiva (GAWLINSKI, 2003), principalmente se comparada à postura de usuários frente ao computador, que normalmente é ativa. A TV está associada a lazer, entretenimento e informação. Outro efeito desta associação da TVi com atividades de lazer é que a interface deve ter uma boa satisfação subjetiva, ou seja, utilizar uma interface de TVi deve ser uma atividade agradável (DRUCKER et al., 2002).

No entanto, é importante observar que assistir à TV não é uma atividade exclusivamente passiva. No estudo etnográfico realizado por Carey (1996b) diversas pessoas conversavam diretamente com a TV, por exemplo para "avisar" o personagem de um filme que algo estava para acontecer ou comentan- 
do algum aspecto do programa. Gawlinski (2003, p. 206) afirma que, apesar da atitude passiva (lean back) ser predominante, em alguns programas, como eventos esportivos e programas de jogos (quiz shows), os usuários tendem a ser extremamente ativos (lean forward), gritando e gesticulando de forma bastante ativa. Ou seja, a postura do usuário pode variar muito de acordo com o conteúdo apresentado.

Mas assistir à TV continua sendo uma atividade de lazer e portanto é muito importante que a interface seja fácil de usar. Por este motivo muitos autores (MAYER, 2003; GAWLINSKI, 2003; LU, 2005; DALY-JONES, 2003) ressaltam que as interfaces de TVi devem ser o mais simples possível.

Outro aspecto importante é o tempo de resposta do sistema, que deve seguir os valores de referência já conhecidos para o ser humano (GAWLINSKI, 2003):

- 0,1 segundo: é o limite para ter a ilusão de que o sistema está reagindo instantaneamente; todas as respostas abaixo deste valor tendem a ser percebidas como instantâneas;

- 1 segundo: é o limite para não interromper a linha de pensamento do usuário, a ilusão de manipulação direta é quebrada mas não é necessário nenhum aviso para o usuário;

- 10 segundos: é o limite para manter a atenção do usuário em uma mensagem; esperas mais longas que isto devem permitir que o usuário faça outra atividade enquanto espera. Para tempos de resposta entre 1 e 10 segundos é necessário indicar que o sistema está ocupado, mas que não parou de funcionar e informar o tempo de espera estimado, principalmente se for variável.

De forma geral, o tempo de 0,1 segundo deve ser seguido para as respostas do sistema, mesmo que seja uma resposta intermediária e o tempo de 1 segundo para a resposta definitiva. Por exemplo, ao trocar canais, o usuário pode receber a informação textual em menos de 0,1 segundo, confirmando que a tecla do controle remoto foi pressionada e o sinal compreendido. Já a troca de canal em si deve levar menos de 1 segundo, para não interromper a linha de pensamento do usuário. 
Daly-Jones (2003) também ressalta que a TV é um meio que prende a atenção do usuário e cria um "túnel de atenção", onde elementos periféricos são ignorados (NORMAN, 1990, p. 164). Por este motivo, os usuários esquecem de olhar para o controle remoto e têm problemas quando a única alternativa para acessar uma função é através de uma tecla que não estão acostumados a usar no controle remoto. Gawlinski (2003, p. 210) também aponta que alternar a atenção entre a tela da TV e o controle remoto pode ser irritante e demorado, recomendando que grande parte da interação seja feita por um número reduzido de teclas no controle remoto.

\subsection{Análise de Tarefa}

Apresentamos a seguir os principais resultados da análise de tarefa. Conforme descrito no item 3.2 primeiro serão mostrados os resultados das análises do ambiente e depois das tarefas elencadas.

\subsubsection{Análise do Ambiente}

\section{Ambiente do Torcedor Antenado}

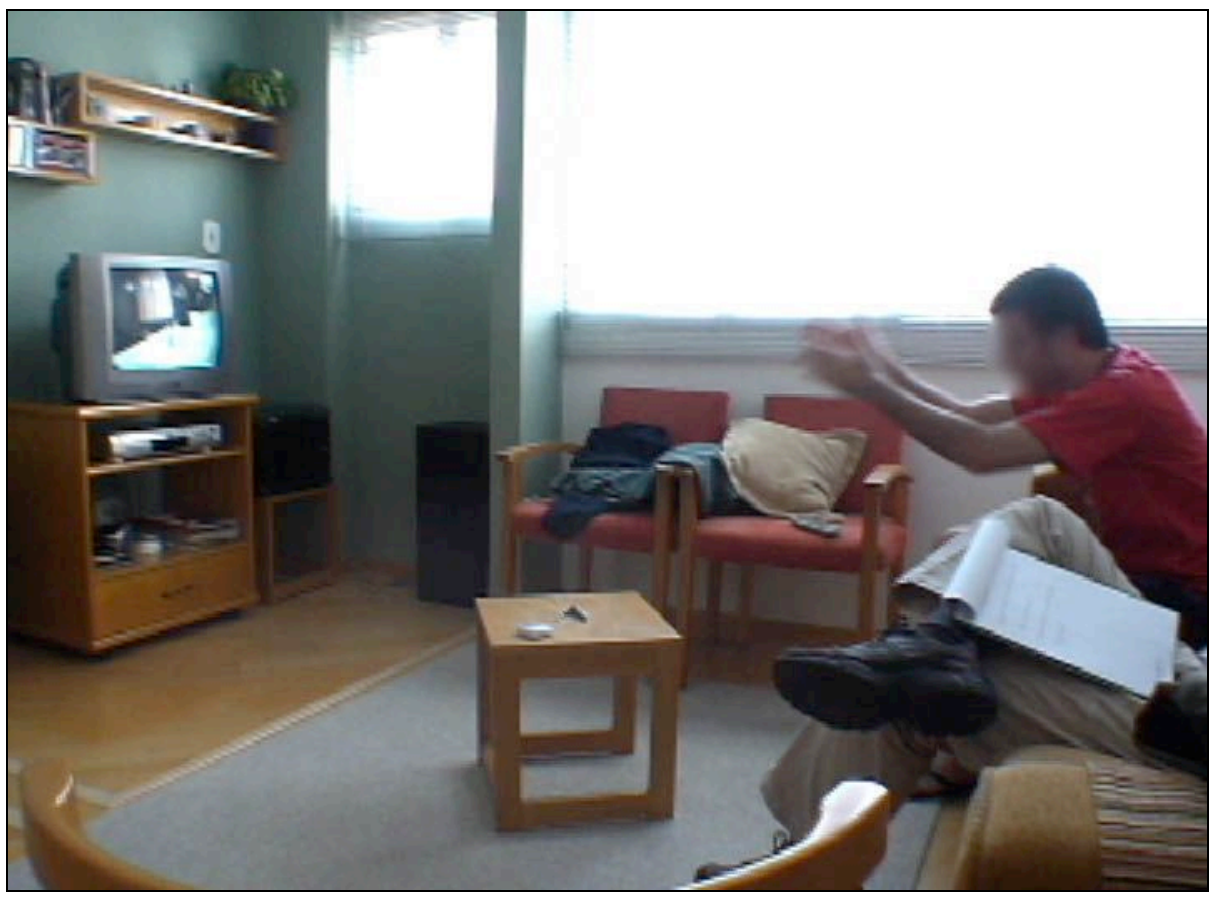

Figura 4-1 - Exemplo de ambiente de uso de Torcedor Antenado 
Em termos de arranjo físico o ambiente de uso costuma ter sua configuração física ditada pela posição do aparelho de TV, com os móveis organizados em função da sua posição. Outras atividades realizadas no ambiente também são levadas em conta (receber visitas, leitura, etc.) mas não tem a prioridade do aparelho de TV (Figura 4-1).

Esta prioridade não é seguida no que diz respeito à distância de uso. As pesquisas desenvolvidas nesta área são baseadas no conceito de distância ótima de uso, que segundo Whitaker (2001, p. 74) é aquela que permite perceber os detalhes com maior precisão, mas onde ainda não é possível ver os artefatos da tela. Como esta medida varia em função do tamanho da tela é normal utilizar a altura da tela $(\mathrm{H})$ como valor de referência. Para aparelhos com definição padrão (SDTV) a recomendação da ITU é que esta distância seja entre $4 \mathrm{H}$ e $6 \mathrm{H}$ (SILVER et al., 2005). A distância de uso de fato acaba sendo em função do tamanho do ambiente e da posição dos móveis e a distância ótima acaba sendo um fator secundário.

O ambiente costuma ser silencioso, com a principal fonte de som sendo a própria TV. A iluminação normalmente é indireta e tende para a penumbra. O ambiente é bastante descontraído, normalmente a sala de estar e eventualmente o quarto (uma segunda TV). A TV é o foco de atenção da atividade e normalmente não há interrupções.

O usuário costuma assistir à TV no final do dia, depois do trabalho e assim, está geralmente bastante cansado. É vista como uma atividade para relaxar e freqüentemente acompanhada de alguma coisa para beber e comer.

Em termos de atenção e prioridade existem duas situações bem distintas para este modelo, a de um jogo esperado e a de ligar a TV para ver o que está passando. Na primeira situação é um programa esperado (uma final de campeonato) e envolve um certo planejamento. Durante o jogo a atenção é muito focada e concentrada na TV. Na segunda situação não existe um programa específico para ser assistido, mas o usuário liga a TV para ver se alguma coisa lhe interessa. Neste caso a atenção é mais dispersa e a prioridade de assistir à TV é bem mais baixa. 
Ambiente da Mãe Ocupada

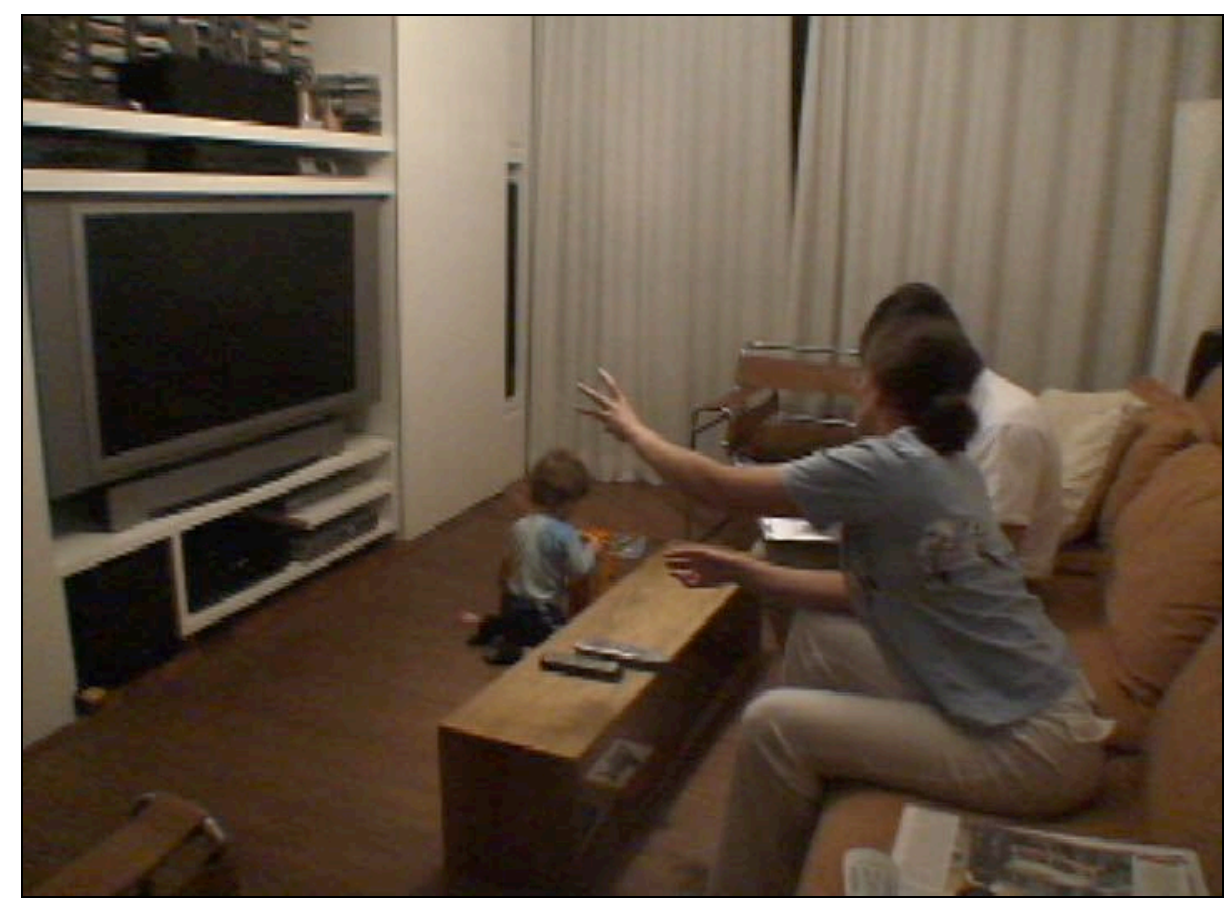

Figura 4-2 - Exemplo ambiente de uso de Mãe Ocupada

Em termos de características físicas o ambiente para este modelo de usuário é praticamente igual ao ambiente do modelo de usuário anterior. Em termos de uso, no entanto, existem diferenças.

O uso da TV se dá de uma maneira integrada à outras atividades e ambientes da casa. $\mathrm{O}$ usuário freqüentemente está assistindo à TV enquanto faz outra coisa (arruma quarto, durante um lanche) e mesmo quando senta a frente da TV não é raro que esteja fazendo outra coisa (por exemplo, lendo o jornal). No exemplo aqui ilustrado (Figura 4-2) a pilha de jornais (canto inferior direito da foto) fica neste local porque é lida enquanto a TV está ligada.

Em outro caso, apesar de existir uma sala de home-theater (com TV digital, inclusive) o usuário assiste à TV no quarto. Para explicar o porquê da escolha, responde:

MO1 (Mãe Ocupada 1): “... não tem nada para fazer lá (home-theater) que não seja ficar assistindo televisão ..." 
Em termos de atenção e prioridade a TV é vista como algo interessante, mas com prioridade baixa e as interrupções são freqüentes, tanto por eventos externos (telefone, criança) como por vontade própria (lembra de alguma coisa, vai fazer algo).

A atividade costuma ser feita no meio ou final de tarde e mais tarde, à noite. Estes dois horários representam duas situações distintas, pois à tarde é feita sozinha e com total controle sobre o que está sendo assistido enquanto que à noite a atividade é feita com o marido, que normalmente fica com o controle remoto.

\subsubsection{Análise das Tarefas}

\section{Ligar e Desligar o Equipamento}

Esta atividade é bastante clara e objetiva, e era esperado que fosse simples, mas nem sempre foi o que aconteceu. O fator de complicação é a existência de mais de um aparelho que deve ser controlado (televisor, terminal de acesso, aparelho de som) e mais de um controle remoto que deve ser utilizado. Quando existe apenas um controle e um aparelho a relação entre controle e aparelho é única e existe pouco espaço para dúvida (Figura 4-3). Quando existe mais de um aparelho e de controle duas perguntas surgem. Que aparelho eu devo utilizar para controlar esta função (volume, canal, legenda)? Que controle comanda o aparelho desejado? (Figura 4-4.)

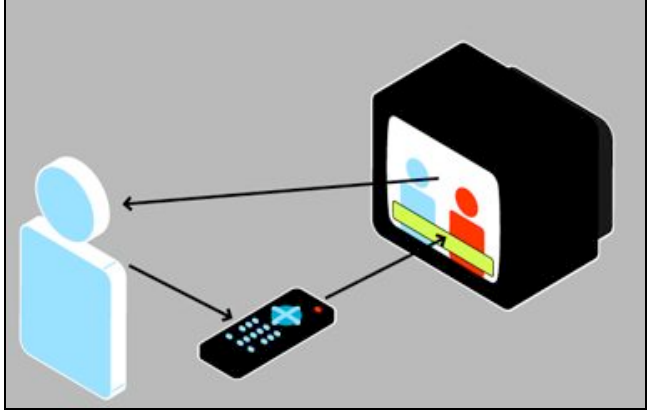

Figura 4-3 - Relação única entre usuário, controle e aparelho

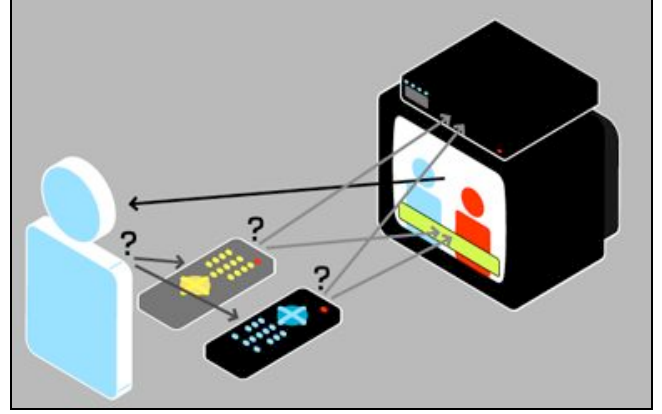

Figura 4-4 - Relação passível de dúvida com mais de um controle 
Nos ambientes vistos apenas TA1 (Torcedor Antenado 1) utilizava apenas um controle. $\mathrm{O}$ controle remoto de $\mathrm{MO} 2$ (Mãe Ocupada 2) foi programado pelo marido para controlar todos os aparelhos (4 no total), mas é necessário primeiro selecionar o aparelho que vai ser controlado (colocar no modo correto) e depois realizar a tarefa. Portanto, para ligar o sistema são necessários quatro passos ao invés de um: mudar controle para controlar TV, ligar TV, mudar controle para controlar terminal de acesso, ligar terminal de acesso.

TA3 e MO3 utilizam apenas um controle para ligar a TV e o terminal de acesso, mas é necessário um controle externo para ligar o aparelho de som, que é por onde o som é reproduzido.

Além de precisar de mais de um controle, algumas funcionalidades podem ser feitas por mais de um aparelho. O caso típico é o volume e o mudo, que podem ser controlados tanto no terminal de acesso quanto no aparelho de TV.

Os usuários TA normalmente não tem problema com esta atividade e muitas vezes foram eles que planejaram a instalação. No caso dos usuários $\mathrm{MO}$, no entanto, a tarefa de ligar e desligar o sistema é um procedimento decorado, pouco compreendido e caso alguma coisa não dê certo pode ser necessário recorrer a ajuda para conseguir ligar o sistema.

MO1: “... eu sei que eu tenho que ligar aqui (controle remoto TV) ... este botão aqui ó, tem que apertar duas vezes ... aí este daqui funciona (controle remoto terminal de acesso)"

A recomendação para este problema seria que os diversos aparelhos que compõe o sistema deveriam funcionar de modo integrado, comportando-se como um sistema apenas, e não como diversas partes que precisam ser controladas separadamente. O controle remoto também deveria ser único.

Existe também um problema de visibilidade do sistema. No caso dos usuários $\mathrm{MO}$ os passos do procedimento não são compreendidos e a operação é feita como uma "caixa preta". O controle remoto deveria ter uma maior integração com a interface gráfica, permitindo ver e compreender os resultados dos comandos enviados pelo controle remoto. 
Os controles remotos modais também causam problemas. Controles modais são aqueles onde é necessário primeiro selecionar o aparelho que se quer controlar (escolher o modo) e depois enviar o comando, como é o caso descrito do controle integrado de $\mathrm{MO} 2$.

Em uma interface modal um mesmo comando gera resultados diferentes de acordo com o modo em que o sistema está e o usuário tem que lembrar em que modo está para enviar um comando e ter o resultado esperado. Em diversas situações os usuários entrevistados tiveram problemas com controles deste tipo, conforme pode ser visto nesta passagem:

Entrevistador: “E para desligar como você faz?”

MO3: “Aqui (pega controle terminal de acesso) ... aliás, não (deixa controle terminal de acesso, pega controle TV) ... (tenta desligar duas vezes) ... acho que este controle não está funcionando direito (mexe nas pilhas do controle remoto) ... (tenta desligar a TV mais seis vezes) ... (olha para o controle, vê que está no modo errado, muda e desliga a TV)"

Entrevistador: “O que é que estava acontecendo?"

MO3: “Tava no ... tava aqui no DVD, no botão errado."

A recomendação neste caso seria evitar interfaces modais, que são conhecidamente problemáticas e induzem a erro. Uma forma para isto seria aumentar a visibilidade do sistema, deixando evidente o estado atual em que o sistema se encontra. Vale citar que no caso descrito o controle remoto acende uma luz vermelha indicando qual aparelho está sendo controlado cada vez que uma tecla é pressionada. No entanto, o usuário estava olhando para a TV e ignorou este indicador repetidas vezes até que olhou para o controle remoto e percebeu o problema.

\section{Selecionar Conteúdo e Trocar de Canal}

Nesta tarefa TA1 e TA2 têm procedimentos praticamente idênticos. O primeiro recurso é a memória, caso tenham algum programa específico que 
planejam ver. Caso não tenham, ligam a TV e digitam o número de alguns canais já conhecidos (canais de esporte), caso não encontrem nada que interessa, TA1 normalmente vai para canais de documentários enquanto TA2 vai para canal de notícias. Caso nestes canais também não haja nada de interessante daí percorrem os outros canais. TA1 vai de canal em canal enquanto TA2 (que tem TV digital) vai pela tarja de informações. Caso não encontrem nada que interesse, desligam a TV.

TA3 também tem como primeiro recurso a memória, para um programa de esporte ou de música (também gosta muito de música), mas caso não tenha nenhum programa específico vai consultar o que está passando pelo guia de programação. No guia de programação não sabe os números dos canais, mas sabe a localização aproximada dos canais que interessam na grade de canais do guia. Como vários canais similares estão agrupados, o usuário se refere à "faixas de canais" de interesse (filmes, seriados, etc.) ao invés de canais específicos.

Desta forma, TA3 navega pelo guia e verifica a programação baseado na descrição textual do programa apenas. Como este usuário tem um PVR (que permite gravação) ele olha não só os programas atuais mas vê o que vai ser exibido nas próximas horas. Um detalhe mencionado por TA3 diz respeito à ordenação crescente dos canais no guia de programação. Esta ordenação é a mais natural para listas de forma geral, com os primeiros números acima (canal 1, 2, 3) e os últimos números abaixo (canal 98, 99, 100, etc.).

No entanto, ao utilizar o controle remoto (na TV analógica ou TV digital), os canais estão ordenados na forma inversa, para se ir para um canal de numeração maior é necessário "subir" (ir do canal 4 para o canal 5, por exemplo) e os canais de numeração menor estão "em baixo". Esta inversão da ordem causa um estranhamento que gera problemas para este usuário.

TA3: "No começo eu me atrapalhava um pouco para subir e descer ... hoje em dia eu já entendo bem."

Entrevistador: "Porque que você se atrapalhava para subir e descer?" 
TA3: “É que eu não sabia se esse aqui ó (tecla para baixo) ... porque quando você está apertando para baixo, os canais estão indo para baixo ... (aperta tecla para baixo) ele foi para baixo, mas a programação subiu (!) então eu nunca entendi ... se eu quisesse ver um acima (do canal N) eu aperto para cima ou para baixo? Se for um acima vai pensar que é um para cima, só que não vai, vai para baixo, entendeu? ... não, é para cima mesmo, tá certo né? ... No começou eu estranhava um pouquinho."

Este usuário, apesar de não utilizar a tarja de informações para trocar de canal (ele normalmente vai até o guia e volta para a TV), utiliza a tarja para saber o nome do programa, horário de início e fim e a sinopse de um filme.

No caso dos usuários MO a memória (lembrar de algum programa interessante e se planejar) é menos importante, principalmente para programas durante à tarde, pois não sabem se vão poder assistir. Desta forma, normalmente ligam a TV e vêem o que está passando naquele momento, pois é quando podem ou querem assistir à TV. Os 3 casos vistos sabem o número de um canal específico que digitam e vão andando daquele canal para cima. Foram também percebidas as mesmas diferenças em função da plataforma. MO1 (TV analógica) vai andando de canal em canal, MO2 (TV digital) utiliza a tarja de informações e MO3 (PVR) utiliza a tarja de informações, mas vê a programação atual e a programação do resto do dia para ver se há algo que vale a pena gravar.

MO1 e MO2 preferem programas pequenos, normalmente seriados ou documentários que podem assistir a apenas um trecho, e só se interessam por filmes mais à noite. À tarde dificilmente conseguirão assistir a um filme até o fim. No caso de MO3 isto não é um problema, devido ao recurso de gravação do seu sistema, e por este motivo quando se interessa acaba vendo filmes e se necessário coloca para gravar para continuar assistindo depois.

A partir destes dados é possível dizer que tanto o guia de programação quanto a tarja de informações são elementos da TV digital que auxiliam muito na atividade de selecionar conteúdo. 
Chama a atenção que as estratégias empregadas por usuários de sistemas analógicos e digitais são muito semelhantes, sendo que no sistema digital elas são apenas melhoradas pelo sistema. Isto é um indicador de que neste caso a tecnologia está alinhada com as metas dos usuários, facilitando e melhorando uma tarefa.

Ao navegar pelos canais (TV analógica) e pela tarja de navegação e guia de programação (TV digital) os usuários utilizam o sistema olhando para a tela da TV, e selecionam a maioria das teclas do controle remoto pelo tato. Os usuários somente olham para o controle remoto quando vão utilizar algumas teclas cuja posição está longe das teclas que estão utilizando ou para procurar alguma tecla que não estão acostumados a usar.

Um bom exemplo disto é o caso de $\mathrm{MO} 2$, cujo controle remoto é um controle Universal, tipo de controle que consegue controlar diversos dispositivos. Este controle foi programado pelo marido de MO2, que teve o cuidado de respeitar o arranjo físico do controle original da plataforma, que era utilizado anteriormente.

Por este motivo, ao controlar o terminal de acesso os rótulos das teclas utilizadas não tem relação nenhuma com as teclas indicadas, mas, como a posição das teclas mais importantes foi respeitada, MO2 utiliza este controle sem ter problemas com os rótulos incorretos do seu controle remoto. É interessante que $\mathrm{MO} 2$ conseguiu utilizar o controle original durante a entrevista sem precisar de uma grande adaptação. 


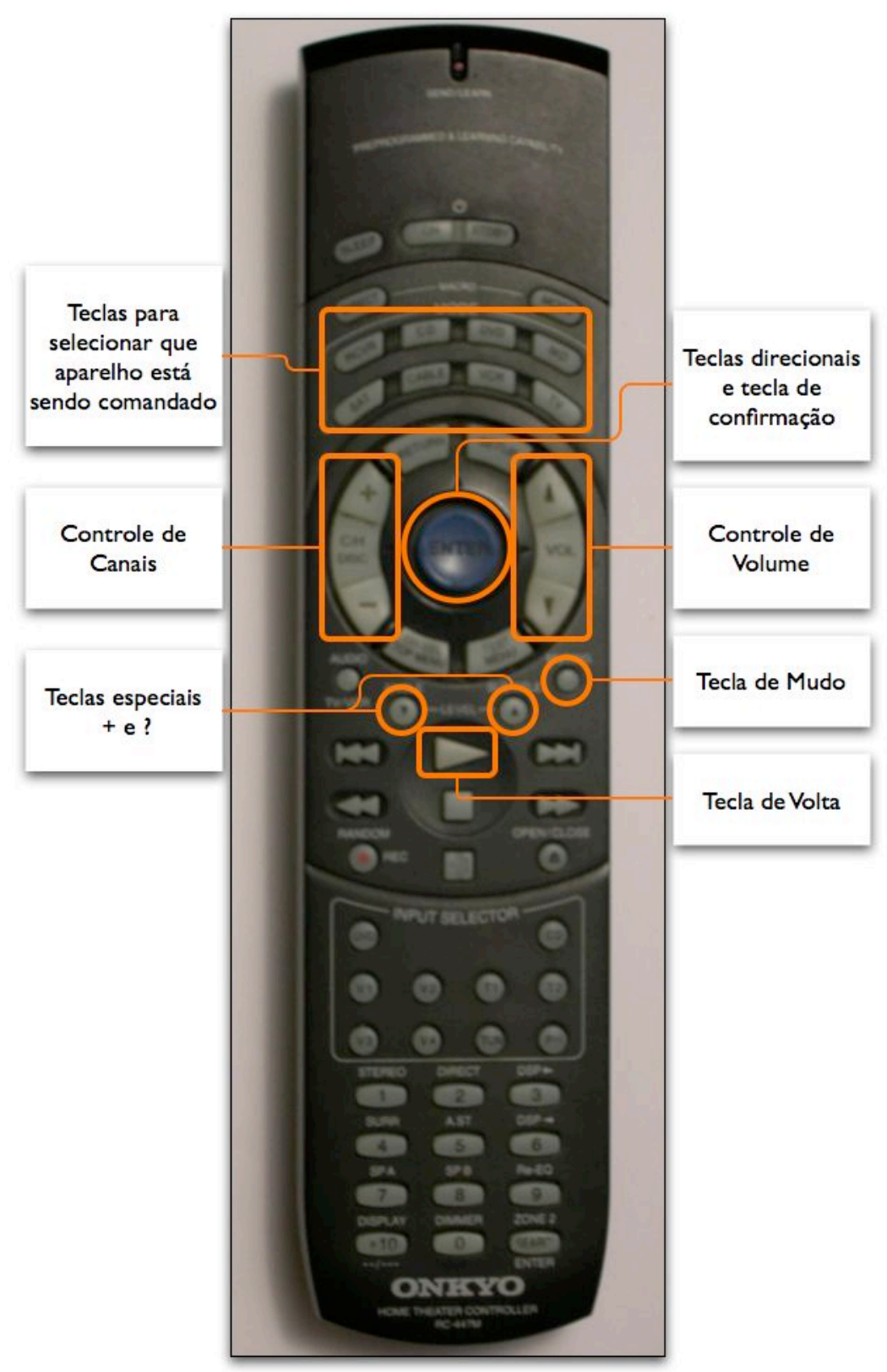

Figura 4-5 - Controle utilizado por MO2

A Figura 4-5 apresenta o controle utilizado por MO2 e na Figura 4-90 podemos ver o controle original da plataforma.

A recomendação é que o controle remoto possa ser utilizado com um conjunto reduzido de teclas (ao alcance do dedo) que possam ser identificadas pelo tato, para não ser necessário olhar para o controle remoto durante a operação do sistema. 


\section{Ajustar o Volume}

De maneira geral os usuários entrevistados procuram deixar a TV em um volume baixo, que não chegue a atrapalhar uma conversa. $\mathrm{O}$ uso do volume foi citado em situações onde é necessário tirar o volume (toca o telefone), quando é utilizada a tecla Mudo.

Também foi citado o caso de canais diferentes terem variação no volume, assim como um programa e seus comerciais. Nesta situação o volume é ajustado, mas de maneira geral permanece estável.

Os problemas encontrados no ajuste de volume são devidos à existência de dois controles e dois aparelhos, análogo ao que foi descrito ao ligar e desligar o aparelho. Assim, esta é uma outra atividade onde mais de um controle e controles remotos modais têm um impacto negativo.

Vale citar que apesar de ser uma atividade que os usuários disseram utilizar pouco ela tem muita importância e é crucial que seja possível controlar o volume, mesmo que isto não seja freqüentemente.

\section{Trocar Legenda e Áudio Alternativo}

Os usuários entrevistados tiveram preferência pelo o áudio original (inglês ou português) e alguns gostariam de poder tirar a legenda (em filmes) ou trocar a legenda para inglês em alguns programas. A funcionalidade de troca de legenda não é possível na TV analógica e os usuários da TV digital disseram não ter esta funcionalidade no seu sistema. A funcionalidade de closedcaption da TV analógica não era utilizada.

Um problema na utilização de áudio alternativo é que alguns canais com programação em português ficam mudos caso esta opção esteja ativada, enquanto outros continuam funcionando com o áudio em português, o que confunde o usuário. Este problema ocorre devido a uma falta de visibilidade do sistema e a recomendação é que o sistema deixe claro quais as opções disponíveis e como alterar seus valores.

Uma situação interessante ocorreu com TA1. Apesar de não usar closedcaption, quando o assunto foi abordado na entrevista ele foi até o menu de 
configurações e conseguiu ativá-lo por lá. Posteriormente viu que havia uma tecla no controle remoto dedicada para ativação e desativação desta funcionalidade e se lembrou que também poderia ter feito por ali. Apesar de saber que este recurso existia e que podia ser ativado, o usuário não lembrava que ele podia ser feito por uma tecla dedicada no controle remoto, mas conseguiu achar esta funcionalidade no menu de configuração e utilizá-la por lá.

A partir deste fato, pode-se recomendar que haja uma boa integração entre interface gráfica e controle remoto, e que teclas dedicadas no controle remoto possam ser acessíveis através do uso da interface gráfica e das teclas de navegação, que são de uso mais comum.

Desta forma, funcionalidades específicas importantes para alguns usuários podem ser acessadas rapidamente através de teclas dedicadas, que funcionam como atalhos. Usuários que não as utilizam freqüentemente podem recorrer à interface gráfica, que é menos eficiente mas de maior facilidade de memorização.

Outro erro nesta tarefa aconteceu devido à interface de ativação de legenda e áudio alternativo ser uma interface modal, desta vez na interface gráfica. A tecla que ativa esta funcionalidade tem outra função caso a tarja de informações esteja aberta. Por este motivo, quando MO3 foi demonstrar esta funcionalidade (ela já havia feito esta tarefa com sucesso durante a entrevista) entrou no modo errado e não conseguia sair, pressionou diversas teclas (inclusive a tecla correta, mas no modo errado) e passou por várias telas. Conseguiu realizar a tarefa mas levou um minuto e vinte segundos para conseguir abrir a interface de ativação de legenda.

\section{Usar Aplicativos de TVi}

Os quatro usuários de TV digital tinham aplicativos de TVi disponíveis (tabela de campeonato, jogos, informações gerais), mas os únicos dois aplicativos utilizados eram programas de TVe. Um deles era um programa de notícias utilizado por TA2 (para saber resultado dos jogos do dia) e o outro um programa que dá a previsão do tempo, utilizado por MO2. Os outros dois usuários que têm TV digital disseram lembrar que existem aplicativos, mas que 
não os utilizam porque alguma vez já experimentaram e não viram nada de interessante.

Um dos problemas citados por TA2 e MO2 era que o aplicativo demora para responder e tem funcionalidade limitada.

MO2: “... eu uso (aplicativo TVe de previsão do tempo) se eu não conseguir ver pela internet. Na internet é mais gostoso, mais fácil, mais rápido e tem mais dias, é mais preciso. Mas eu não vou ligar o computador, esperar ele "bootar" para ver a previsão do tempo. Mas se ele está ligado eu vejo lá ..."

Durante as entrevistas ao se falar em TV interativa foram muitas as comparações com o computador. Por exemplo, MO2, ao falar que a aparência e navegação dos aplicativos (e do sistema de uma forma geral) deixa a desejar, diz:

MO2: “... a aparência, as navegações podiam ser mais bonitinhas né? $\mathrm{O}$ computador tá aí pra provar, ... é meio precariazinha assim, é como se você tivesse vendo o computador em DOS, mais ou menos isto ..."

Mesmo para MO1, que não tem TV digital mas utiliza o computador, ao falar sobre melhorias que imagina para a TV diz:

MO1: “... a televisão, quando ela começou, ela era o máximo de tecnologia que a gente tinha dentro de uma casa ... hoje em dia você tem o computador, e o computador eu acho que te dá uma urgência, você resolve umas coisas no computador, que você fica querendo procurar na televisão ..."

Estes dados indicam que o computador e a internet com banda larga acabam sendo um parâmetro de comparação para estes usuários, e muitas das expectativas se formam baseadas neste outro meio.

Um outro problema encontrado nos aplicativos refere-se à funcionalidade da tecla Volta. A navegação dentro do aplicativo é feita em múltiplos níveis 
(país, estado, cidade, datas) e neste contexto a tecla Volta retorna para o nível anterior.

No contexto de TV a tecla Volta tem a função de alternar entre os dois últimos canais sintonizados e portanto tem apenas um passo em seu histórico. Como o aplicativo de TVe está vinculado a um canal, o usuário espera que a funcionalidade de volta funcione como em um canal. Não é isto que acontece pois a tecla Volta está subindo nos diversos níveis do aplicativo, até chegar ao nível superior, e só então volta para o outro canal.

MO2: “... ele (aplicativo TVe de previsão do tempo) é engraçado que tem um "bugzinho", você fica voltando e ele demora para voltar ... aparece um monte de coisa antes de voltar para o canal que eu estava ... tem que dar várias vezes o comando para eu voltar onde eu estava."

Neste caso a recomendação é que a funcionalidade de volta deve se comportar da mesma forma em todos os contextos do sistema. Se existe a necessidade de uma tecla que troque entre os dois últimos canais, esta pode ser uma outra tecla do controle remoto, mas a funcionalidade de volta não deve ser distorcida em função de contextos distintos.

A latência e a falta de indicadores de que o sistema está aguardando informações também são um problema. Os usuários que o utilizam já sabem que, uma vez ativado, o sistema não dá indicação clara de que está carregando por alguns segundos e só então aparece o aplicativo.

Quando foi mencionado o uso de aplicativos de TVi MO3 lembrou que tinha visto isto no canal de previsão do tempo e foi até este canal. O ícone indicador de conteúdo interativo demorou para aparecer e MO3 saiu do canal e tentou navegar pelo sistema. Voltou para o canal e desta vez ficou procurando até que o ícone apareceu. Para ativar o aplicativo não utilizou a tecla dedicada do controle remoto (que tem um ícone igual ao que aparece na tela), mas pressionou a tecla de confirmação, que também ativou o aplicativo.

A recomendação neste caso é que existam indicadores de acordo com os valores de referência apresentados no item 4.1.5. 


\section{Ajustar as Configurações}

Esta tarefa apresenta uma divisão clara entre os dois modelos de usuários entrevistados. Os usuários TA fazem esta tarefa eventualmente, somente quando é necessário modificar alguma configuração. Já os usuários $\mathrm{MO}$ não realizam esta tarefa porque não tem interesse, mesmo sabendo onde estas configurações podem ser feitas.

Uma vez que esta tarefa é feita eventualmente, a recomendação é que seja de fácil memorização.

\section{Obter Ajuda}

A distinção mais importante nesta tarefa está entre os usuários de TV analógica e TV digital, e não entre os modelos de usuários.

TA1, que tinha TV analógica, relatava que era muito difícil ter algum problema, e que quando isto acontecia era um problema na sua região. Nesta situação não há muito o que fazer e ele deixa de assistir à TV para fazer outra coisa.

Quando MO1 (também com TV analógica) tinha algum problema buscava ajuda dos filhos ou do marido. Se não fosse algo rapidamente resolvido também desistia de assistir à TV e buscava outra atividade.

No caso dos usuários com TV digital o procedimento era ligar para o serviço de suporte da TV por assinatura e receber instruções pelo telefone para realizar um procedimento. TA3 relatou que algumas vezes teve problemas que foram resolvidos simplesmente desligando e religando o equipamento. Em todos os casos, se o usuário não conseguia ajuda, deixava de assistir à TV para fazer outra coisa.

A recomendação neste caso é que o sistema tenha poucos erros, e que sejam fáceis de serem corrigidos. Uma vez que assistir à TV é uma atividade de lazer e descontração, os usuários têm uma tolerância muito baixa a este tipo de inconveniente e facilmente buscam outra atividade. 


\subsection{Diretrizes Gerais de Interface}

\subsubsection{Design para TV}

A tela da TV foi projetada para apresentar imagens reais (fotográficas) em movimento. Em contraste, interfaces gráficas são normalmente baseadas em imagens sintéticas (gráficos) e estáticas, que são bem apresentadas em monitores de computador. Devido a esta diferença, são necessários alguns cuidados específicos ao se projetar interfaces para a TV. De maneira geral curvas, movimento, gradientes e bordas suaves são mais adequados (BBC, 2002).

\section{Área Visível e Formatos de Tela}

No sistema PAL-M (analógico) a área visível da tela é aproximadamente equivalente a um formato digital com 480 linhas de altura e 640 pontos por linha. Esta também é a área visível do sistema NTSC-M, mas outros sistemas PAL normalmente trabalham 576 linhas com 720 pontos por linha.

É importante observar, porém, que nem todos os aparelhos de televisão mostram toda a área útil da tela. Por causa disso é uma prática comum deixar uma borda com 5\% de espessura que pode não aparecer em alguns televisores. Esta borda é chamada de action-safe. Além disto, as bordas do monitor de TV nem sempre têm a mesma qualidade da região central, o que pode prejudicar a leitura de algum texto que fique nesta região periférica. Portanto também é uma prática comum deixar uma borda de 10\% de espessura para elementos de texto. Esta borda é chamada de title-safe (GAWLINSKI, 2003).

Desta forma, podemos considerar que a área útil total no sistema PAL-M é de 640 por 480 pixels. Dentro desta área, qualquer informação que não possa deixar de aparecer deve estar dentro da área action-safe, de 576 por 432 pixels. Elementos cuja legibilidade é fundamental, como elementos de texto e de navegação, devem ainda ficar dentro da área title-safe, de 512 por 384 pixels. Estas três regiões estão ilustradas na Figura 4-6. 


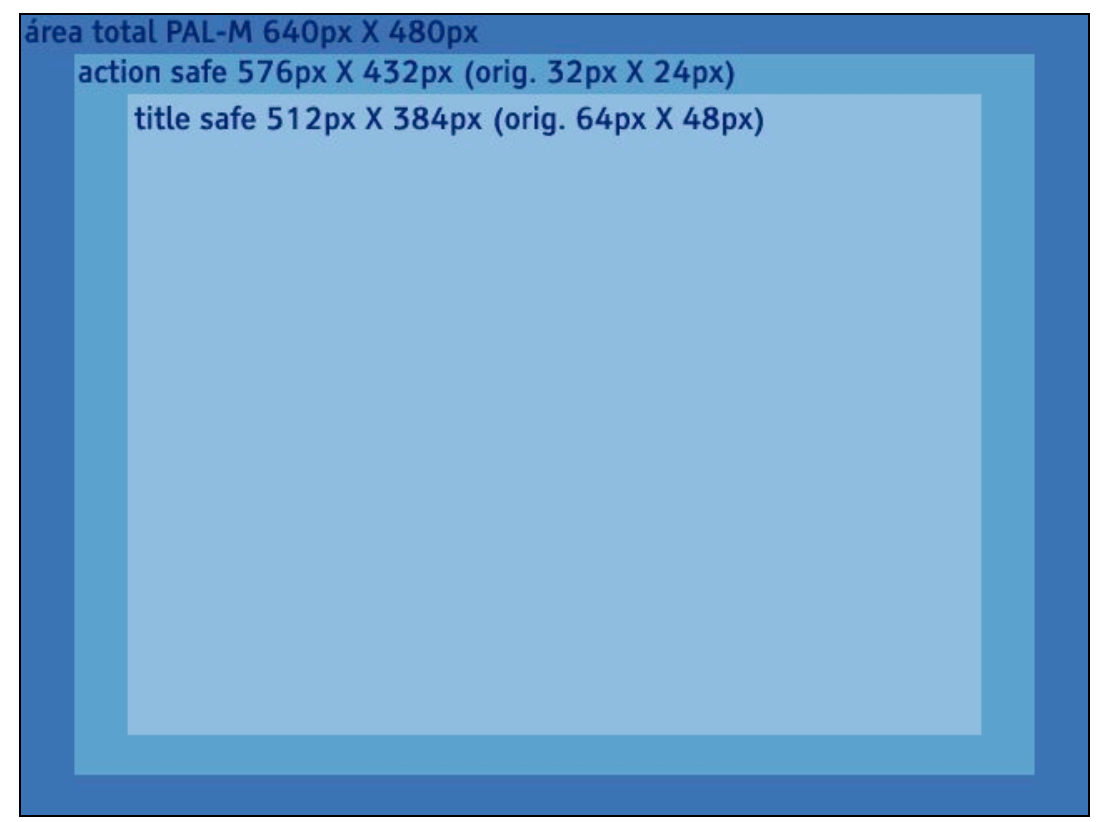

Figura 4-6 - Área visível e bordas de segurança do sistema PAL-M

Estas são as áreas da maioria dos televisores que existem atualmente, cuja tela tem o formato padrão, onde a relação entre largura e altura é 4:3. No entanto, a tendência atual é que cada vez mais aparelhos de TV tenham o formato wide screen, em que a tela é mais retangular e a relação entre largura e altura é 16:9.

As formas de compatibilizar estes dois formatos de tela são através do uso de bordas ao redor do conteúdo ou através do corte da imagem (BBC, 2002). A Figura 4-7 mostra duas imagens originais nos formatos 4:3 e 16:9 e como elas podem ser utilizadas nos outros formatos. 


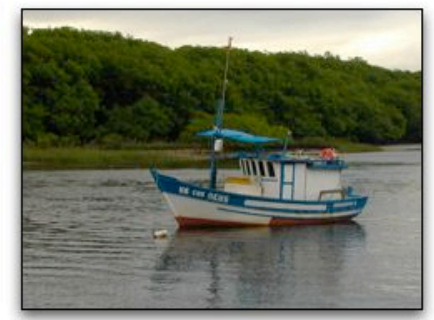

Tela 4:3

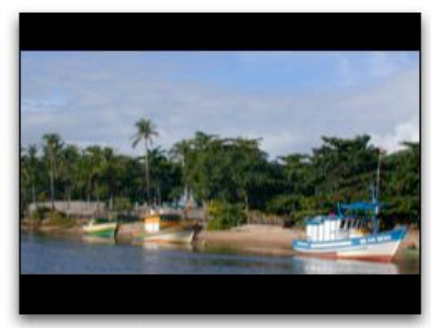

Formato "letterbox"

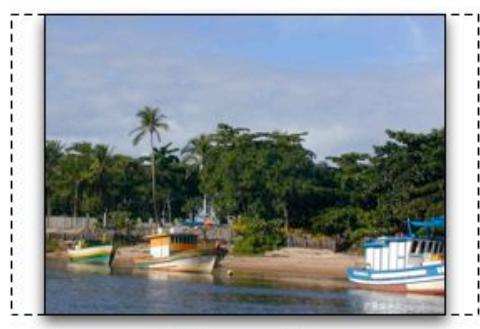

Imagem 16:9 cortada

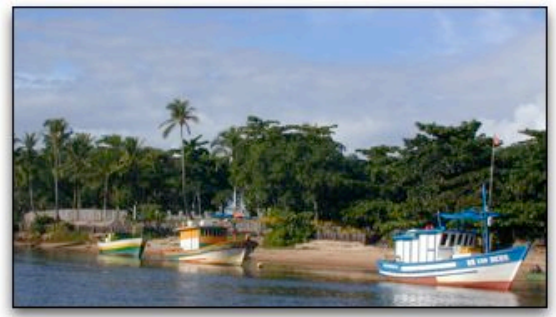

Tela 16:9

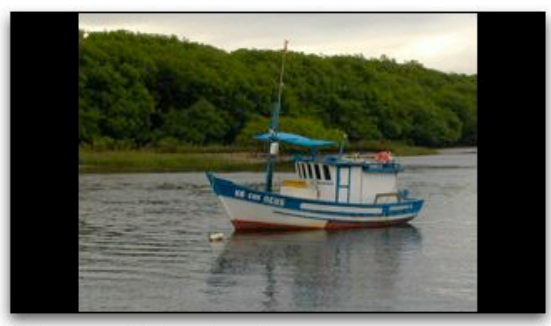

Formato "pillar bars"

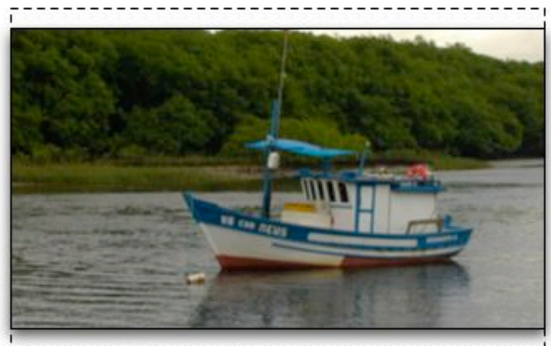

Imagem $4: 3$ cortada

Figura 4-7 - Alternativas para adequação do conteúdo a um formato de tela diferente

\section{Cores e Detalhes}

A tela de televisão também tem um espectro de cores mais limitado do que um monitor de computador. Desta forma é recomendável que não sejam utilizadas cores muito saturadas ou com luminosidade muito alta (GAWLINSKI, 2003). De forma geral as cores utilizadas devem ter valores RGB não menores que 16 e não maiores que 236 (em uma escala de 256 valores) (BBC, 2002; TIRESIAS, 2006).

Outra característica da tela de televisão é que suas linhas são apresentadas de forma alternada na tela, primeiro são desenhadas as linhas ímpares e depois as linhas pares. Desta forma, a tela toda é redesenhada a uma freqüência de $60 \mathrm{~Hz}$, o que dá a ilusão de uma imagem em movimento. As linhas individuais, no entanto, são desenhadas a uma freqüência de $30 \mathrm{~Hz}$, que é perceptível ao olho humano. 
Por este motivo qualquer elemento que tenha apenas uma linha de altura aparecerá piscando na tela, um efeito indesejável e normalmente conhecido como flicker. Este efeito também acontece em bordas horizontais (inferior ou superior) que sejam muito bem definidas, pois a última linha irá piscar na freqüência de $30 \mathrm{~Hz}$. De forma geral este efeito pode ser evitado pelo uso de linhas com no mínimo 2 pixels de altura (TIRESIAS, 2006; BBC, 2002; ARVID, 2004) ou de um filtro para borrar (blur) as bordas da imagem (BBC, 2002; LIBERATE, 2002).

Elementos com muitos detalhes ou com padrões também devem ser evitados (BBC, 2002; GAWLINSKI, 2003; LIBERATE, 2002) pois podem causar o surgimento de padrões de moiré, linhas de interferência que surgem quando dois padrões são sobrepostos. Na Figura 4-9 as linhas verticais são um exemplo de um padrão de moiré que se forma devido à interferência entre linhas horizontais (pretas) e linhas diagonais (laranja).

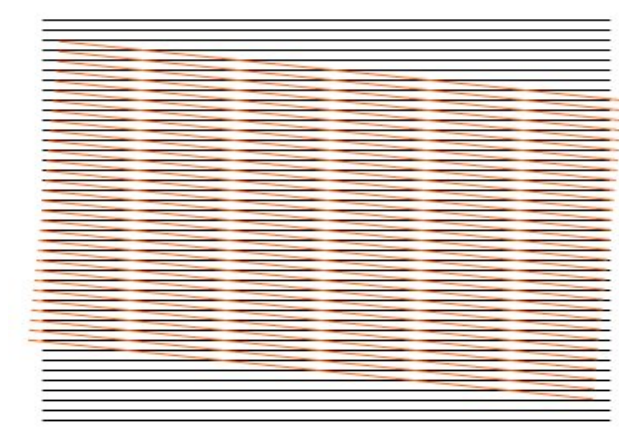

Figura 4-8 - Exemplo padrão de moiré

\section{Tipografia}

De maneira geral o uso de texto na televisão é um desafio pois a definição da tela é baixa e os usuários não estão acostumados a ler textos longos.

Isto faz com que seja recomendável que o tamanho dos tipos seja grande (LIBERATE, 2002). As recomendações para tamanho de tipo variam, mas de forma geral deve-se evitar texto menor que 18 pontos, sendo ideal o uso de 22 pontos ou maior (TIRESIAS, 2006; BBC, 2002; LIBERATE, 2002; GAWLINSKI, 2003). 
Tanto o espaçamento entre linhas quanto entre caracteres deve ser maior do que o utilizado para impressão (TIRESIAS, 2006; BBC, 2002), sendo que uma tela inteira de texto deve conter um máximo de aproximadamente 90 palavras (BBC, 2002).

Como a definição é baixa deve-se dar preferência às famílias de letras sem serifa e sem muitos detalhes (TIRESIAS, 2006; GAWLINSKI, 2003; BBC, 2002; ARVID, 2004; LIBERATE, 2002). Também é recomendável o uso de anti-alias, que suaviza as bordas das letras. Na Figura 4-9 são apresentados exemplos de tipos com e sem serifa e do efeito do anti-alias.
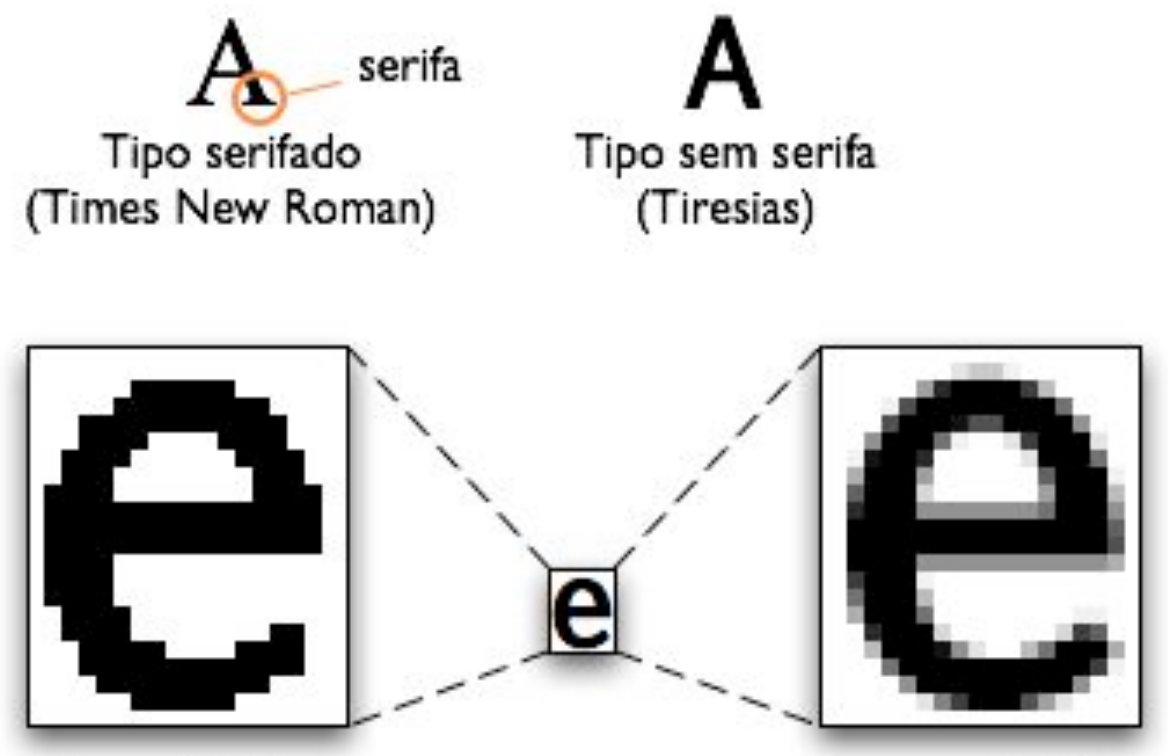

Sem anti-alias

Com anti-alias

Figura 4-9 - Exemplo de tipo serifado e sem serifa e efeito de anti-alias aplicado à letra e.

Como exemplos de boas famílias de tipos para TV podemos citar a Tiresias, Gill Sans, Gill Sans Bold, Zurich e Univers (TIRESIAS, 2006; BBC, 2002; LIBERATE, 2002; GAWLINSKI, 2003). Na falta destas famílias deve-se escolher famílias sem serifa, como a Trebuchet. Na Figura 4-10 são apresentados exemplos de boas famílias de tipos para TV. 


\title{
Tiresias \\ ABCDEFGHIJKLMNOPQRSTUVWXYZ abcdefghijklmnopqrstuvwxyz 0123456789.,;:?!@()*/+-
}

\author{
Gill Sans \\ ABCDEFGHIJKLMNOPQRSTUVWXYZ \\ abcdefghijklmnopqrsturwxyz \\ 0123456789.,;:?!@(0*/+- \\ Trebuchet \\ ABCDEFGHIJKLMNOPQRSTUVWXYZ \\ abcdefghijklmnopqrstuvwxyz \\ $0123456789 ., ; ; ? !$ ! ()$^{*} /+-$
}

Figura 4-10 - Exemplos famílias de tipos adequadas para TV.

O uso de texto claro sobre um fundo escuro também é uma recomendação (TIRESIAS, 2006; ARVID, 2004), sendo o uso de branco sobre azul especialmente apropriado (GAWLINSKI, 2003).

\subsubsection{Navegação}

Em termos de navegação a BBC (2002) apresenta duas possibilidades interessantes: o uso de setas direcionais mais uma tecla de confirmação ou o uso de setas direcionais sem a tecla de confirmação. Porém ressalta que se deve tomar muito cuidado ao mesclar estas duas formas de navegação para não confundir o usuário.

O uso de números como atalhos para navegação também é apresentado como uma alternativa interessante (BBC, 2002; GAWLINSKI, 2003; ARVID, 2004; DALY-JONES, 2003). 
O cursor utilizado deve ser proeminente e claramente destacado do resto da interface (GAWLINSKI, 2003; ARVID, 2004), e deve-se tomar um cuidado especial quando existem apenas 2 opções, pois pode não ficar claro qual item está selecionado e qual não está (ARVID, 2004). Os menus de opções devem ser circulares, ou seja do primeiro item é possível ir para o último e vice-versa (BBC, 2002).

Também é desejável que as instruções de navegação sejam apresentadas na tela, pois muitos usuários não estão acostumados a estes mecanismos (BBC, 2002).

\subsubsection{Dispositivo de Interação}

Como a televisão é um meio que atrai muito a atenção do usuário, é comum que estes busquem por botões na tela e esqueçam de teclas dedicadas no controle remoto (BBC, 2002; DALY-JONES, 2003). Além disto a mudança de foco entre a tela da TV e o controle remoto pode tornar-se cansativa (GAWLINSKI, 2003), e é especialmente prejudicial a pessoas com presbiopia ("vista cansada") (TIRESIAS, 2006). Assim o uso de elementos de tela é preferível ao de teclas dedicadas (DALY-JONES, 2003), e deve-se evitar a alternância de foco entre a tela da TV e o controle remoto (GAWLINSKI, 2003; TIRESIAS, 2006).

As teclas dedicadas no controle remoto devem ser utilizadas para funções muito freqüentes ou para atividades críticas, como é o caso da ativação de funções de acessibilidade. Neste caso, o uso de menus pode ser muito demorado e trabalhoso (TIRESIAS, 2006). Duas teclas são mencionadas especificamente, a tecla Volta, para voltar à tela anterior ou desfazer a última ação e a tecla para voltar à tela inicial (portal) (TIRESIAS, 2006).

Outra recomendação é que o design do controle remoto seja complementar ao design da tela da aplicação e vice-versa (DALY-JONES, 2003). No caso da TV interativa o controle remoto não é um periférico, mas é crucial na interação que se dá entre usuário, controle e a interface na tela.

A entrada de dados pelo controle remoto também deve ser minimizada. No caso da entrada de textos ela deve se limitar a frases curtas ou apenas al- 
guns dados como nome e endereço (GAWLINSKI, 2003). No caso da navegação por menus e de escolhas de opções a opção mais provável deve estar préselecionada, sendo necessária apenas a confirmação da seleção por parte do usuário (GAWLINSKI, 2003).

\subsection{Análise Comparativa}

\subsubsection{Plataforma TV Aberta}

\section{Descrição da Plataforma}

A TV aberta é o paradigma para a maior parte da população, e sua característica principal em termos de uso é a simplicidade. O número de canais disponíveis normalmente não ultrapassa 13 (VHF e UHF) e não é raro que este número fique abaixo de 5. A interação é feita com o aparelho de TV sem a necessidade de um terminal de acesso externo, o que torna a operação do sistema mais simples.

É a única plataforma de acesso gratuito. 
Mapa de Navegação da Plataforma

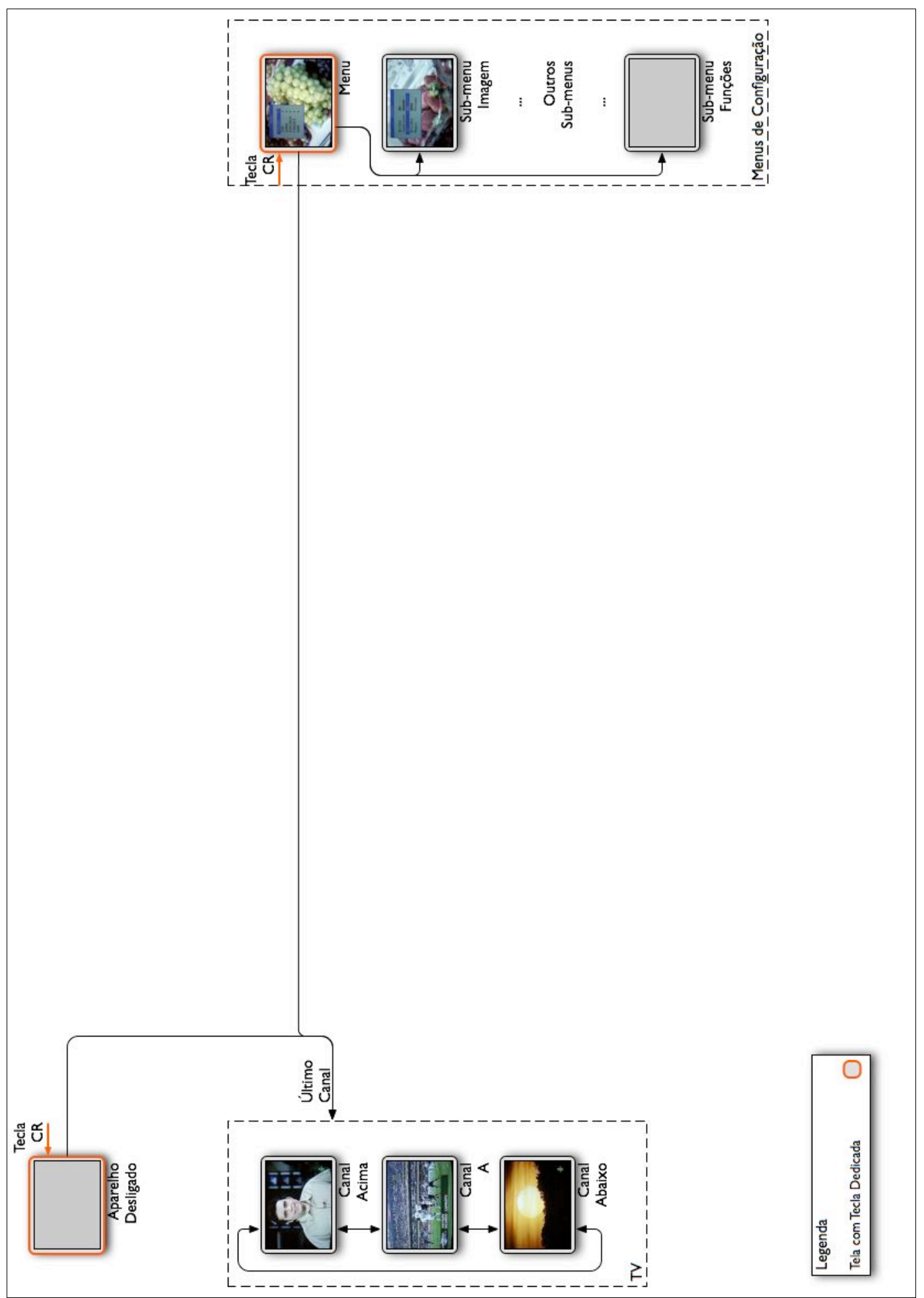

Figura 4-11 - Mapa de navegação da plataforma TV aberta 
O mapa de navegação da TV aberta reflete a sua simplicidade. Estando ligada tem apenas duas alternativas: a navegação pelos canais ou o menu de configuração.

Ao ser ligada a TV entra no canal que estava sintonizado quando foi desligada. Os canais estão organizados de forma seqüencial e num arranjo circular (do último item se vai para o primeiro e vice-versa), o que significa que para passar por todos os canais basta ir em uma direção apenas. Dado o número reduzido de canais não é um grande esforço passar por todos para saber sua programação.

O menu de configuração não tem uma estrutura padronizada, variando de acordo com o aparelho de TV utilizado. Normalmente tem uma estrutura hierárquica com poucos itens (entre 3 e 5) e no máximo dois níveis de profundidade. 


\section{Telas da Plataforma}

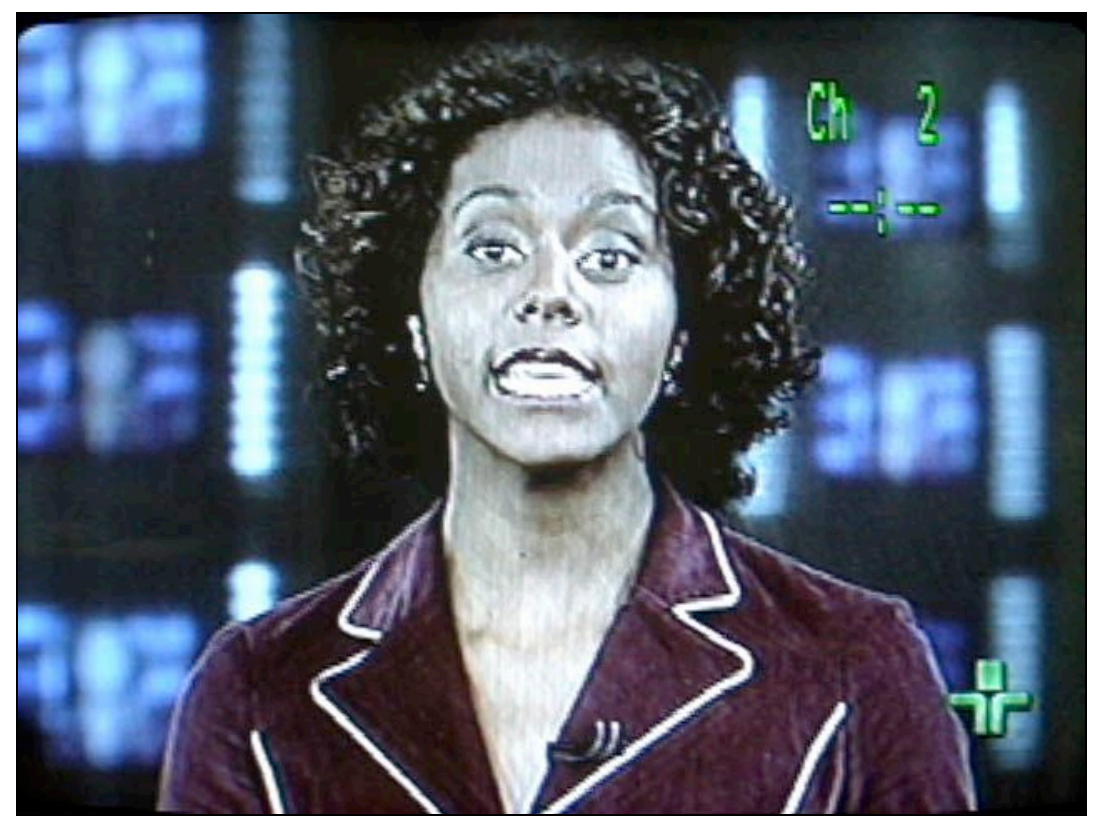

Figura 4-12 - Informações sobre canal na plataforma TV aberta

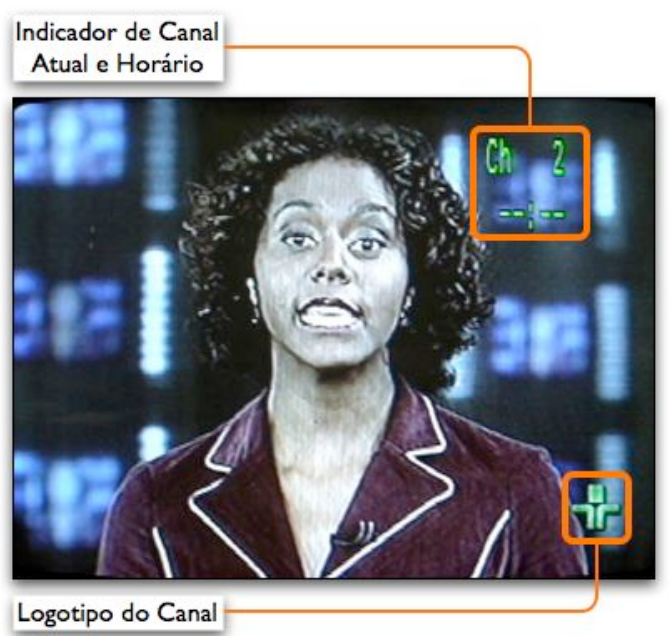

Figura 4-13 - Detalhes das informações sobre canal na plataforma TV aberta
Os únicos elementos de tela que aparecem são o indicador de canal, o indicador de volume e o menu de configuração.

Na primeira tela (Figura 4-12 e Figura 4-13) podemos ver um indicador de canal que aparece por alguns segundos após a troca de canal. Este indicador é o que mais se aproxima da tarja de informações que existe nas plataformas de TV digital.

Neste caso tal indicador também mostraria o horário, mas como esta informação não foi configurada no aparelho (e por ele ser analógico não pode ser extraída da transmissão) o que aparece é apenas a seqüência de caracteres “--:--". 
Também podemos ver nesta tela o logotipo do canal. Este elemento vem inserido sobre o vídeo e não é uma característica exclusiva da TV aberta. Ele é um indicativo que pode ser útil para a orientação para o usuário quando estiver navegando, principalmente nas plataformas analógicas. No entanto, dependendo do conteúdo assistido o logotipo pode se tornar um ruído indesejável (no caso de um filme, por exemplo).

As duas outras telas selecionadas são um exemplo do indicador de volume e do menu de opções. O primeiro aparece sempre que o volume é alterado, inclusive quando a tecla Mudo é acionada (a palavra Volume é substituída por Mudo).

A tela com o menu de configurações é um exemplo do tipo de configuração que existe na TV aberta e da forma como é representado na tela.

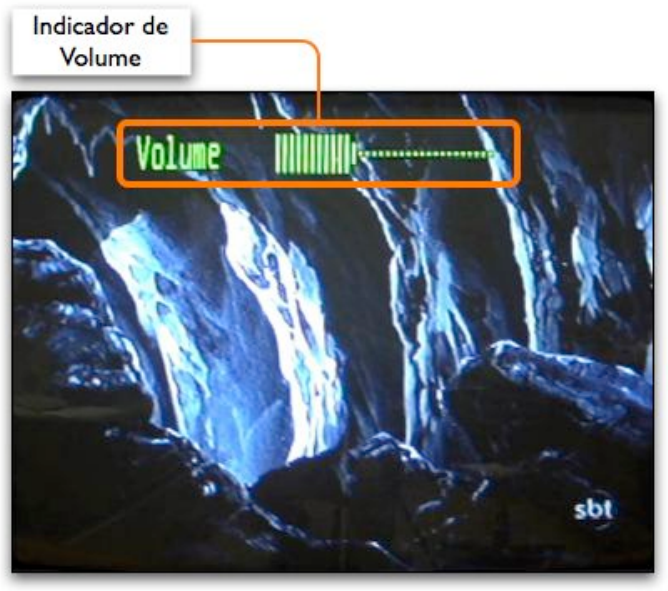

Figura 4-14 - Indicador de volume da plataforma TV aberta

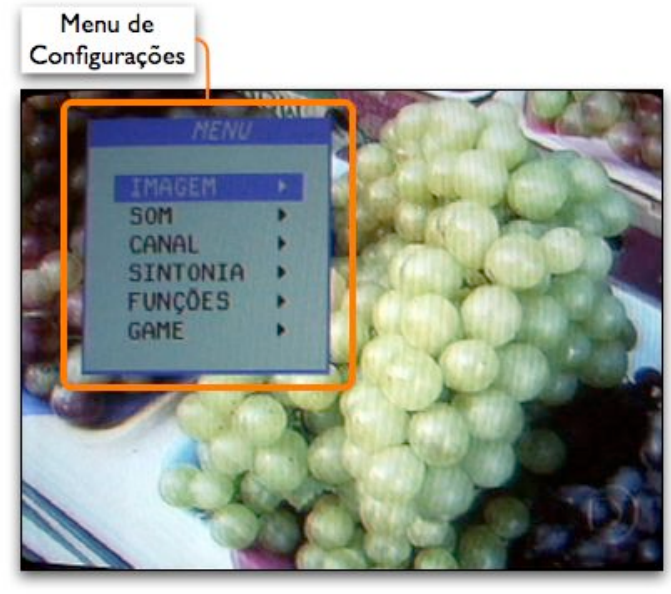

Figura 4-15 - Menu de configurações da plataforma TV aberta 


\section{Dispositivos da Plataforma}

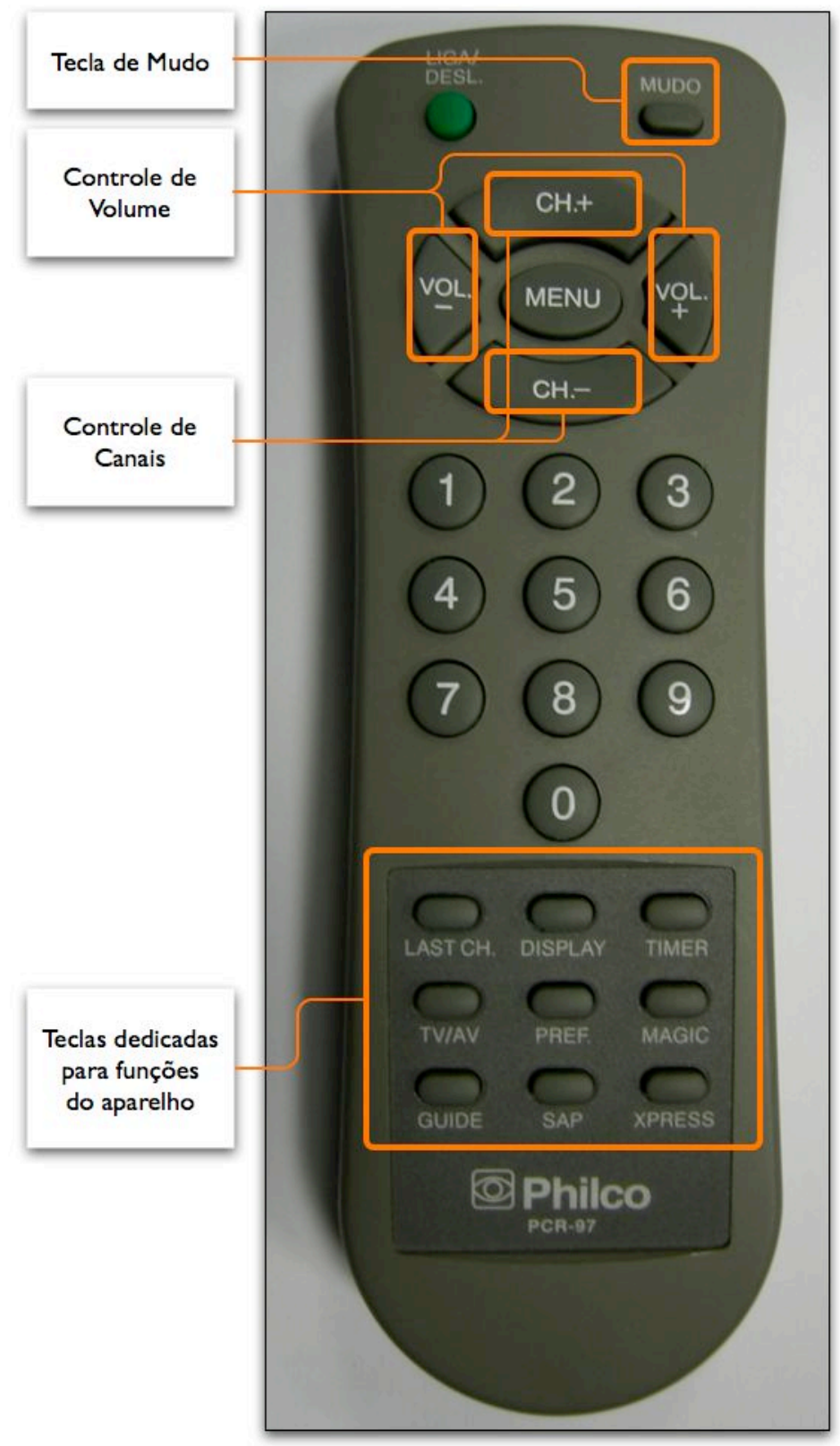

Figura 4-16 - Controle remoto da plataforma TV aberta

O controle remoto da TV aberta (Figura 4-16) tem uma organização de teclas bastante clara. Na parte superior estão as teclas mais utilizadas: liga, mudo, controle de volume e canal. A tecla de menu também está neste grupo, apesar de não ser muito utilizada.

Abaixo está o teclado numérico e na parte inferior estão as teclas dedicadas para funções específicas do aparelho. Estas teclas são bem menores que as outras e não tem diferenciação nenhuma exceto um rótulo para cada tecla. $\mathrm{O}$ 
texto é bem menor em relação ao das outras teclas e os rótulos são pouco descritivos (Xpress, Magic).

Os nomes de algumas teclas estão em português (Liga, Mudo), mas os de outras estão em inglês (Guide, Last Ch.). No total este controle remoto tem 26 teclas, sendo 9 para funções específicas do aparelho.

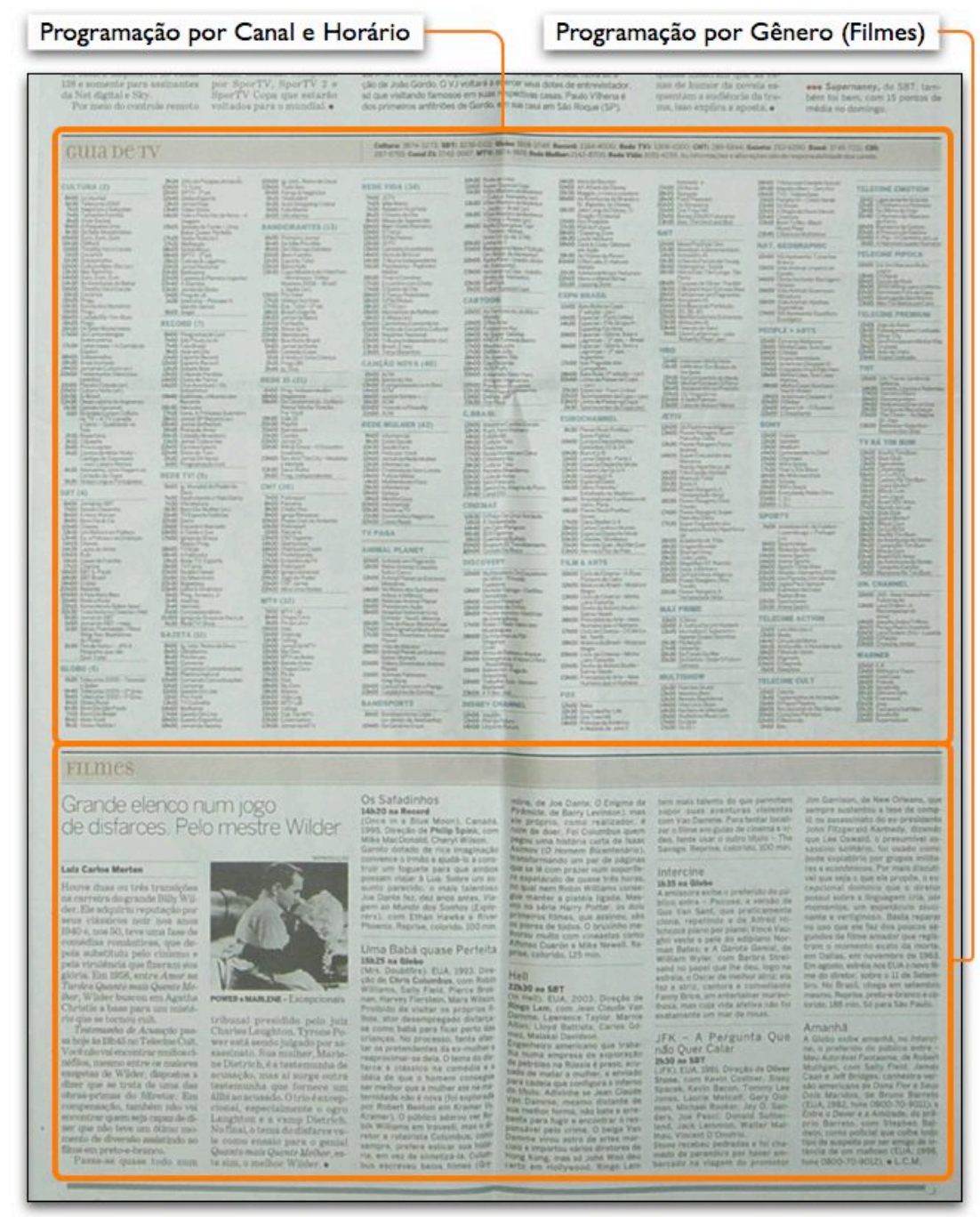

Figura 4-17 - Guia de programação impresso da plataforma TV aberta

O outro dispositivo utilizado na TV Aberta é o guia de programação impresso, presente em jornais. A organização destes guias é por canal e, dentro de cada canal, por horário. Abaixo da programação há um espaço para os destaques da programação no gênero de filmes, com suas sinopses. 


\section{Navegação da Plataforma}

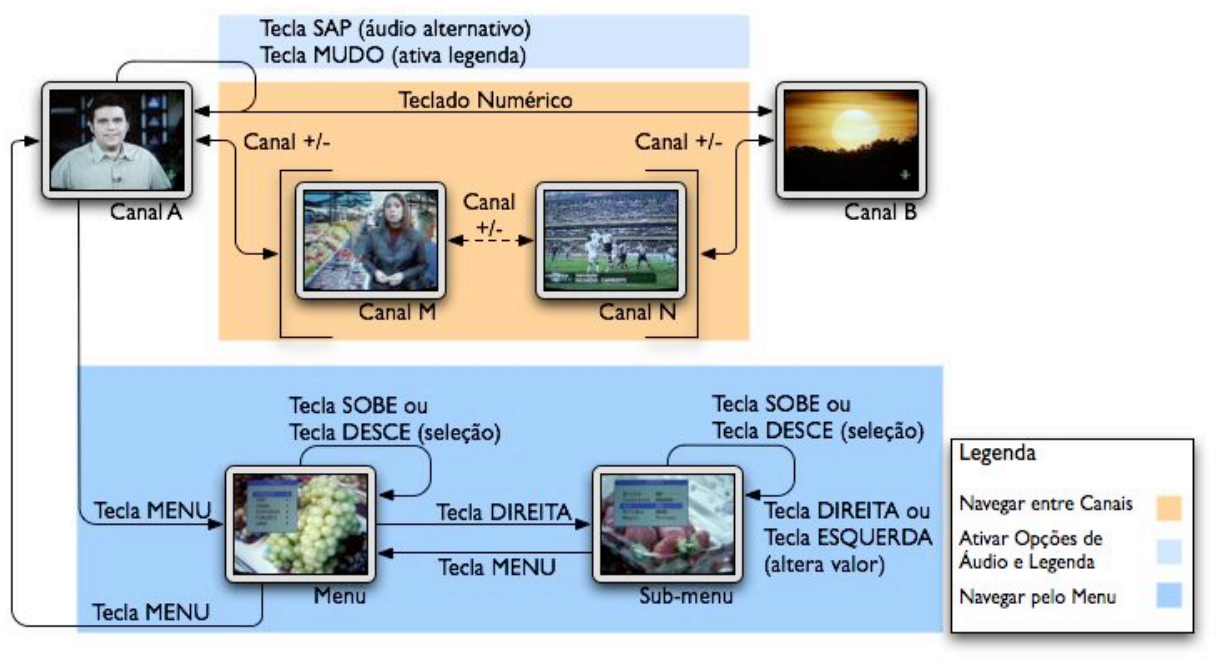

Figura 4-18 - Navegação da plataforma TV aberta

A navegação por canais é praticamente idêntica em todas as plataformas. Os canais são arrumados em um ordem seqüencial, com um número para cada canal. Ela é circular, ou seja, do último canal se vai para o primeiro e viceversa, e desta forma é possível passar por todos os canais indo em uma direção apenas.

A outra forma de navegação possível na TV aberta é a navegação pelo menu de configuração. Ela não é padronizada e muda de aparelho para aparelho, mas normalmente tem 2 níveis hierárquicos, um para escolher o tipo de configuração (vídeo, áudio, timer, etc.) e outro para fazer a configuração em si.

Na plataforma estudada a ativação do menu é feita com a tecla menu no controle remoto, que leva para o primeiro nível de navegação. Neste nível a navegação é feita com as setas verticais (controle de canal) para selecionar o item desejado e com a seta para a direita (controle de volume) como tecla de confirmação. No segundo nível as setas verticais são novamente utilizadas para selecionar o item desejado mas as setas horizontais são utilizadas para modificar o valor do item selecionado. Para voltar do segundo para o primei- 
ro nível é utilizada a tecla menu, e para fechar o menu de configuração utiliza-se novamente a tecla menu.

Mesmo com 2 níveis apenas esta navegação muitas vezes é confusa, pois as únicas teclas que mantêm seu funcionamento nas duas telas são as setas verticais.

\subsubsection{Plataforma TV a Cabo Analógica}

\section{Descrição da Plataforma}

A TV a cabo analógica é muito semelhante à TV aberta, mas apresenta duas diferenças importantes: utiliza um terminal de acesso externo com seu controle remoto próprio e o número de canais é muito maior.

O número exato de canais depende do pacote de serviços contratado, mas é de aproximadamente 50 canais, o que aumenta a importância de um guia de programação. 


\section{Mapa de Navegação da Plataforma}

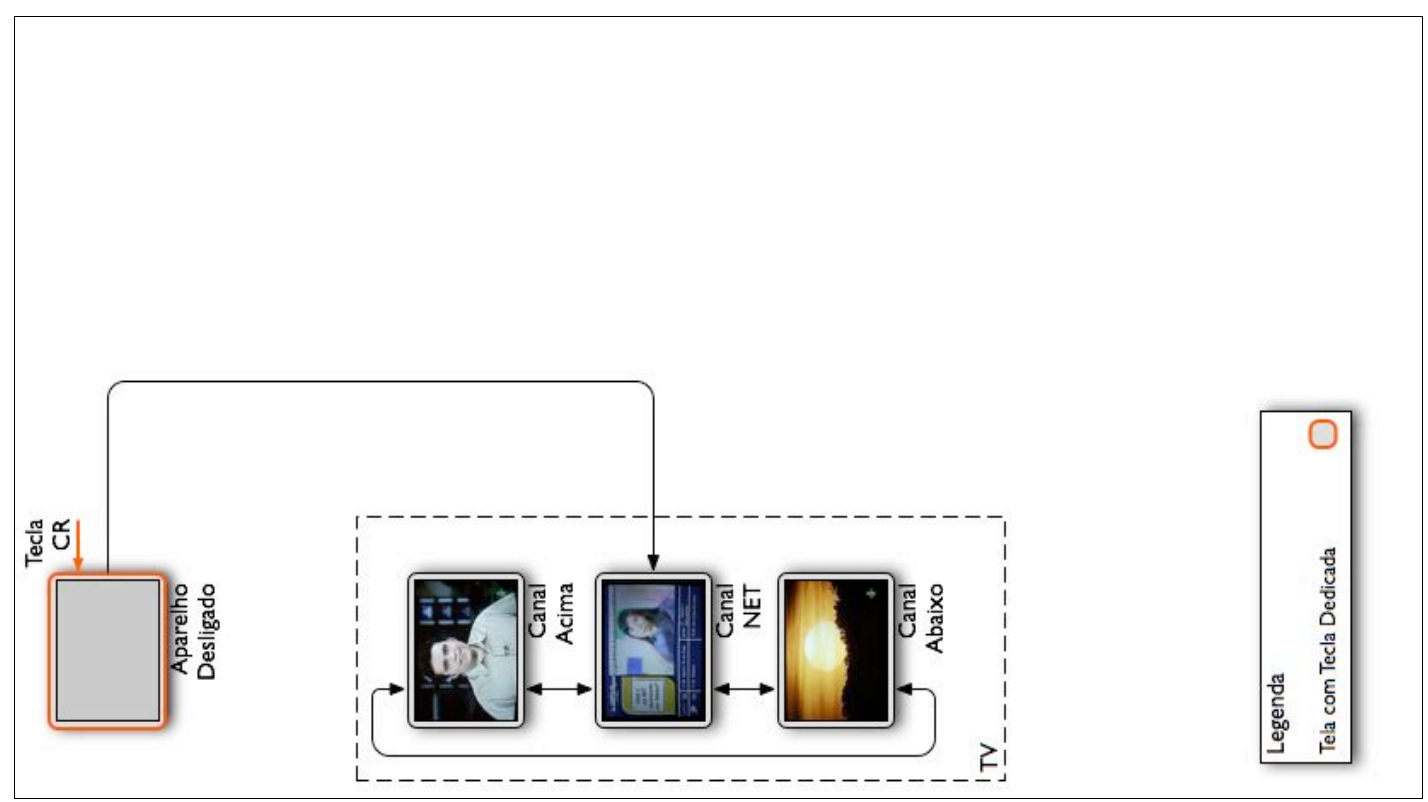

Figura 4-19 - Mapa de navegação da plataforma TV a cabo analógica

A TV a cabo analógica tem apenas a navegação entre canais, pois não apresenta um menu de configuração e o acesso ao menu de configuração da TV é feito por outro controle remoto (o da TV).

No entanto, o número de canais é muito maior e portanto a navegação por todos os canais é uma atividade que exige muito mais esforço que na TV aberta. Alguns canais são agrupados por afinidade (canais de séries, canais de filmes, etc.), o que facilita a navegação.

Ao contrário da TV aberta, ao ser ligada, a TV exibe sempre um canal específico, o canal informativo da operadora com um guia de programação nãointerativo. 


\section{Telas da Plataforma}

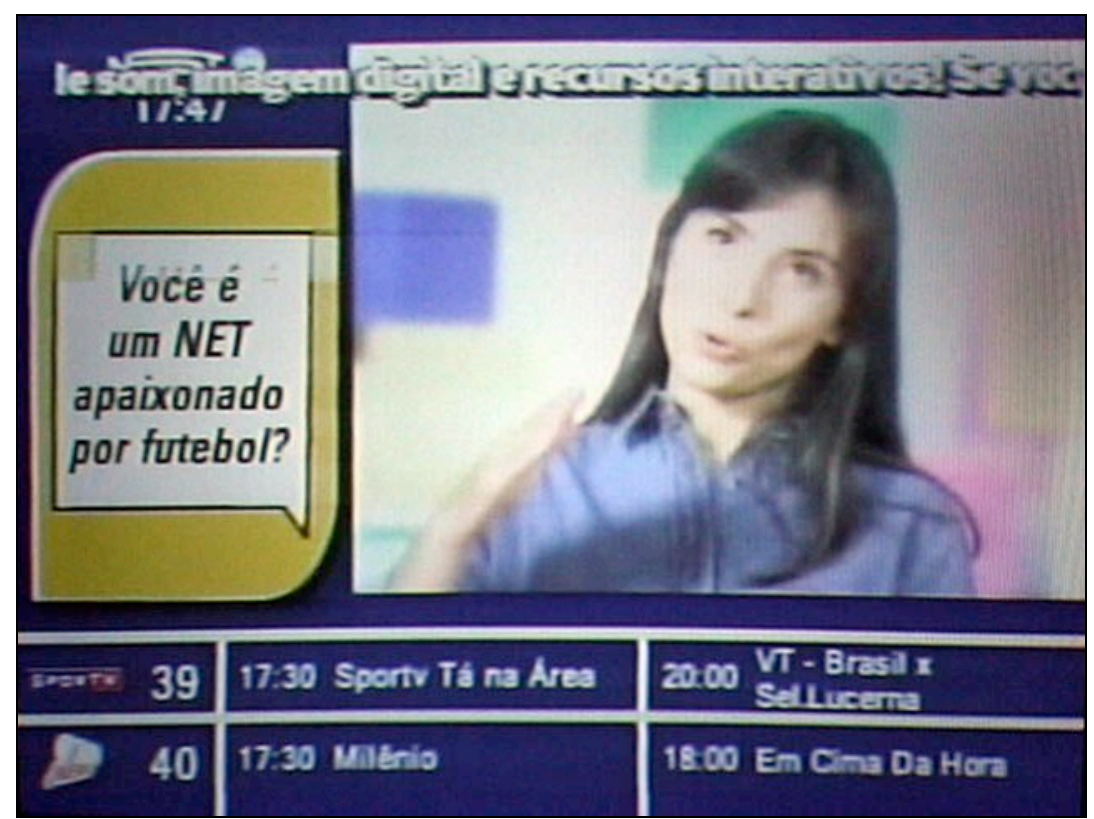

Figura 4-20 - Canal com guia de programação não-interativo

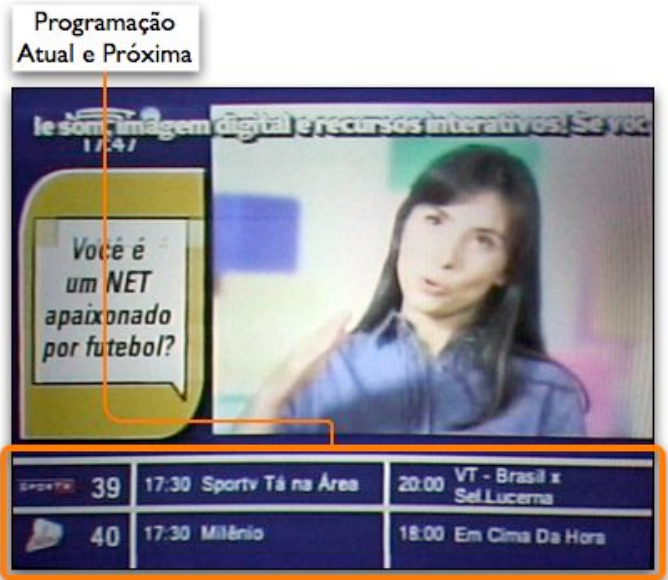

Figura 4-21 - Detalhe de canal com guia de programação não-interativo
A única tela específica desta plataforma é o canal informativo da plataforma, que contém o guia de programação não-interativo (Figura 4-20 e Figura 4-21). Este canal apresenta a programação atual e a próxima de 2 em 2 canais, mudando os canais a cada 10 segundos. Ele mostra a programação de 30 a 40 canais (não a de todos) e portanto são necessários aproximadamente $3 \mathrm{minu}$ tos para ver toda a grade de programação.

Na plataforma analisada o indicador de canal não era mostrado na tela, mas no painel frontal do terminal de acesso (Figura 4-24) e não existia um indicador visual do volume. 


\section{Dispositivos da Plataforma}

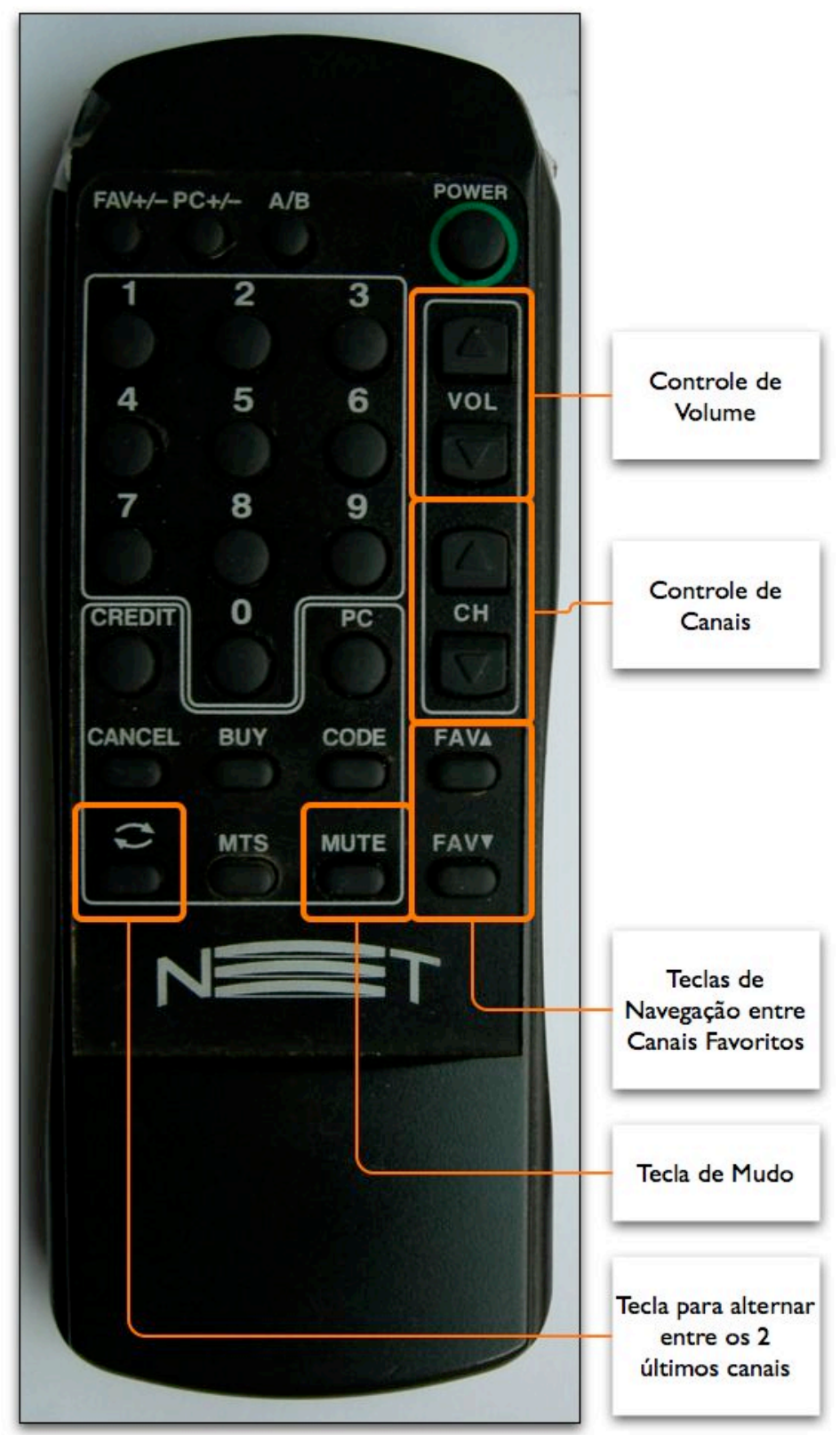

Figura 4-22 - Controle remoto da plataforma TV a cabo analógica

O controle remoto da TV a cabo analógica (Figura 4-22) tem uma organização de teclas mais confusa do que o da TV aberta. As teclas mais utilizadas ficam à direita, o que é desconfortável para usuários canhotos. A tecla Mudo fica distante das teclas de controle de volume e junto de outras teclas que não têm um significado claro (MTS, Code). 
Este controle tem duas teclas para navegação entre os canais favoritos, um conjunto de canais que pode ser definido pelo usuário. Mas a plataforma não deixa claro como este conjunto de canais é criado.

Existe uma tecla para alternar entre 2 canais (vai do canal A para canal B e vice-versa), representada por um ícone de 2 setas. Ela também está presente no controle remoto da TV aberta, mas lá é chamada de Last Ch. No total este controle remoto tem 28 teclas, todas com rótulo em inglês.

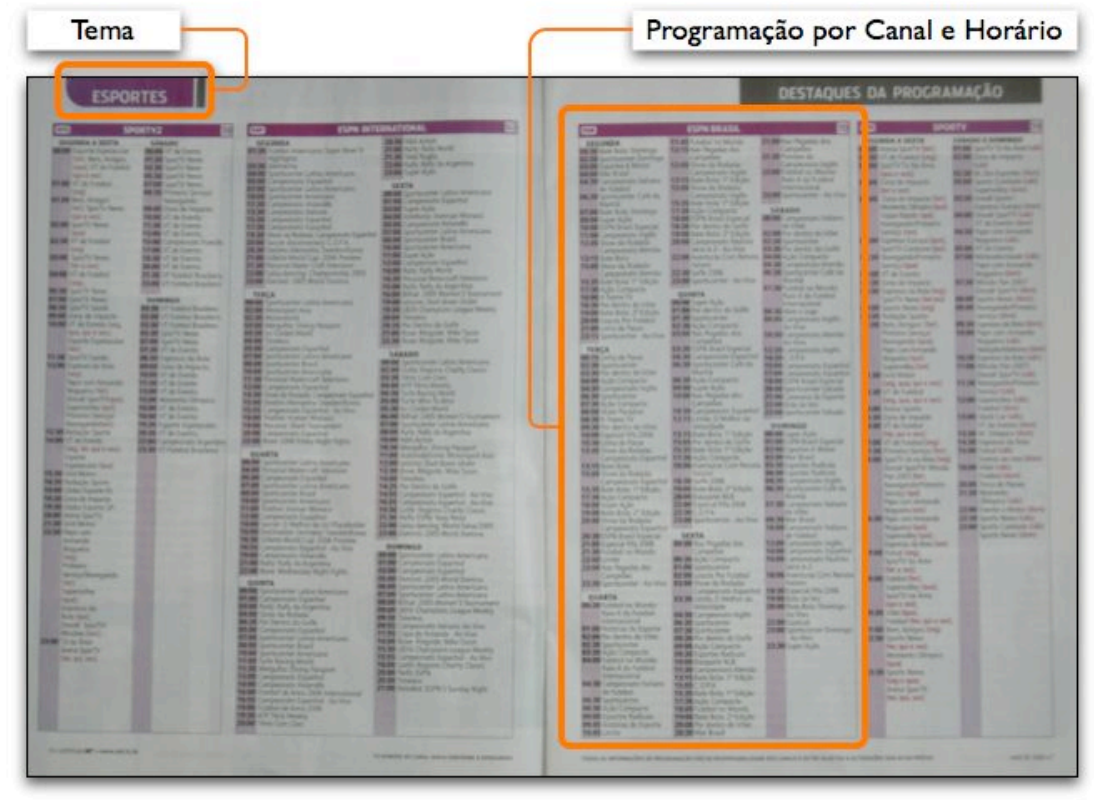

Figura 4-23 - Guia de programação impresso da plataforma TV a cabo analógica

O guia impresso desta plataforma é uma revista mensal comprada pelos assinantes do serviço. A revista é dividida em 5 temas (esportes, filmes, variedades, seriados e infantil) e para cada tema apresenta os destaques do mês e a programação semanal por canal e horário. A exceção são os filmes, que têm a listagem por dia do mês e horário e as sinopses em ordem alfabética. 


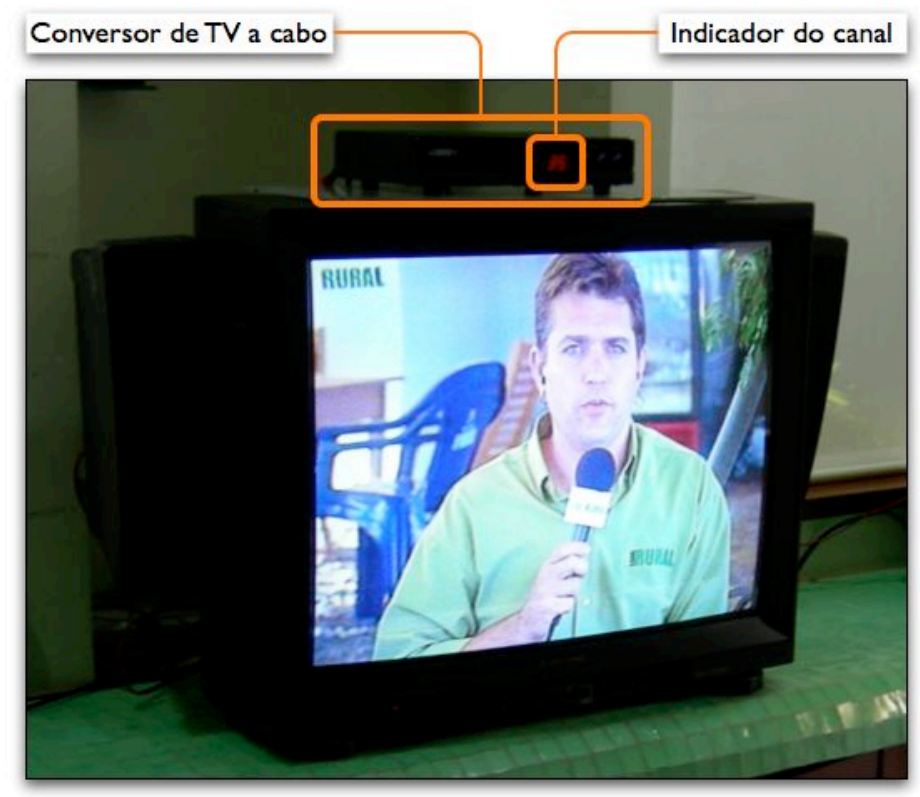

Figura 4-24 - Terminal de acesso da plataforma TV a cabo analógica

A Figura 4-24 mostra o terminal de acesso de TV a cabo e o indicador de canal no painel frontal. Este é o único indicador visual desta plataforma, que não utiliza nenhum recurso gráfico sobre o vídeo.

\section{Navegação da Plataforma}

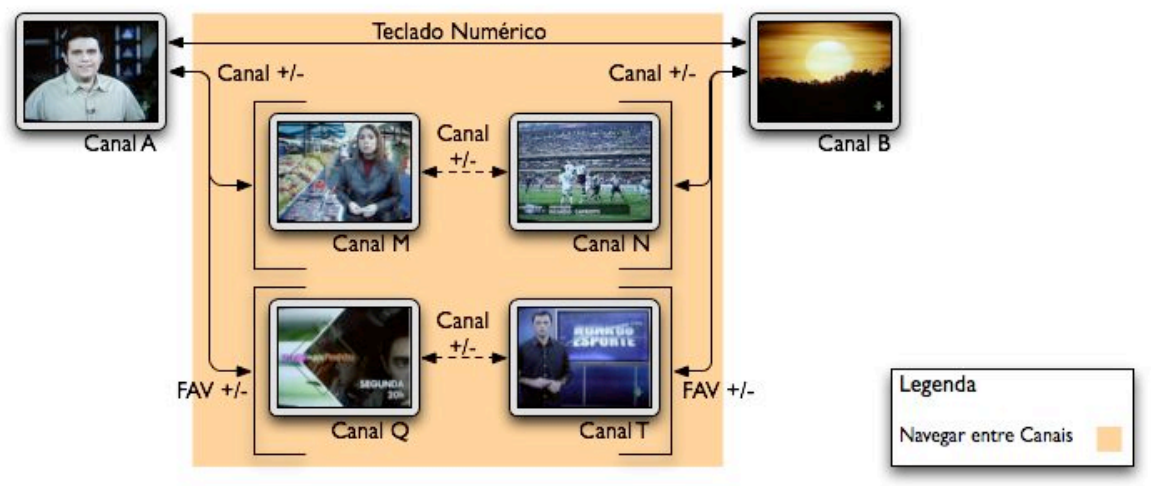

Figura 4-25 - Navegação da plataforma TV a cabo analógica

A navegação por canais segue a mesma estrutura da TV aberta, mas o número de canais é muito maior. Nesta plataforma também procura-se ordenar os canais por afinidade (filmes, séries, infantil).

Na plataforma analisada existe a possibilidade de marcar alguns canais como favoritos e navegar apenas entre eles, mas a forma de marcar um canal 
como favorito não é clara e nenhum canal estava marcado como favorito no sistema analisado.

\subsubsection{Plataforma DirecTV}

\section{Descrição da Plataforma}

A DirecTV é uma plataforma de TV digital via satélite, que tem aproximadamente 40 canais.

Apresenta uma série de características que estarão presentes em todas as plataformas digitais tais como:

- guia de programação interativo;

- tarja informativa sobre o vídeo com informações básicas sobre o programa;

- canais de música (canais que não têm vídeo, somente áudio) e

- canais Pay-per-view (canais para compra de eventos por unidade, como um filme ou uma partida de futebol).

Em termos de uso é a plataforma digital cujo paradigma mais se aproxima da TV analógica. 
Mapa de Navegação da Plataforma

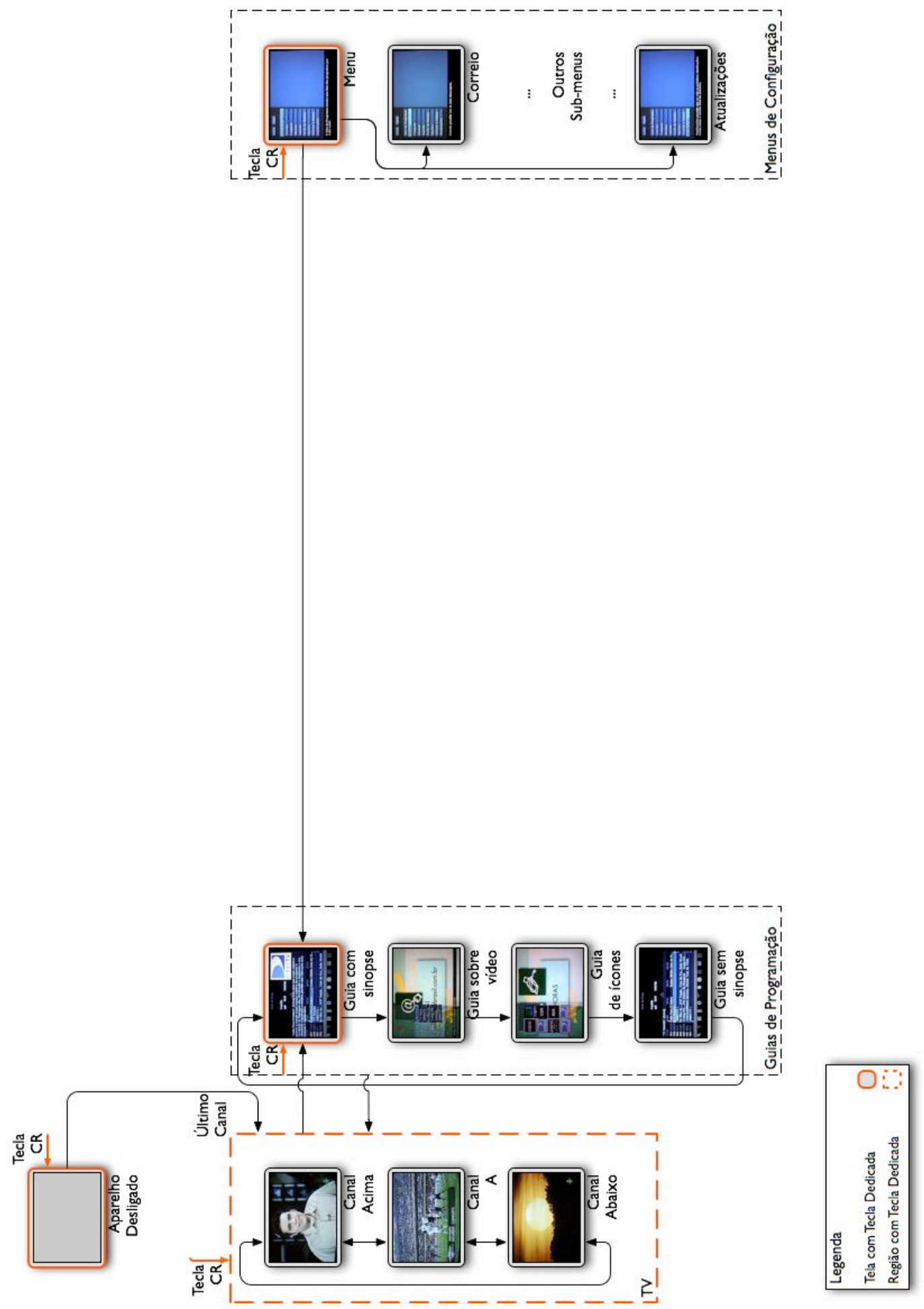

Figura 4-26 - Mapa de navegação da plataforma DirecTV 
O mapa de navegação desta plataforma é bastante simples, mais próximo da TV analógica do que das outras plataformas digitais. É a única plataforma digital que ao ser ligada vai para o último canal sintonizado (como a TV aberta).

O guia de programação desta plataforma tem quatro modos, que serão vistos em detalhes nos próximos itens.

O menu de configuração só é acessível por uma tecla dedicada no controle remoto (e não pela navegação por botões). Neste menu estão todas as configurações da plataforma, organizadas em uma estrutura hierárquica com diversos níveis. Desta forma, algumas funcionalidades mais complexas exigem a navegação por muitas telas em níveis distintos. Por exemplo, a configuração de perfis de uso permite especificar canais permitidos, horários permitidos, censura e limite de gastos para toda a família e para 4 usuários específicos, o que demanda 20 telas em 3 níveis. Esta organização causa um excesso de concentração de funcionalidades em um ponto específico da interface (o menu de configuração). 


\section{Telas da Plataforma}

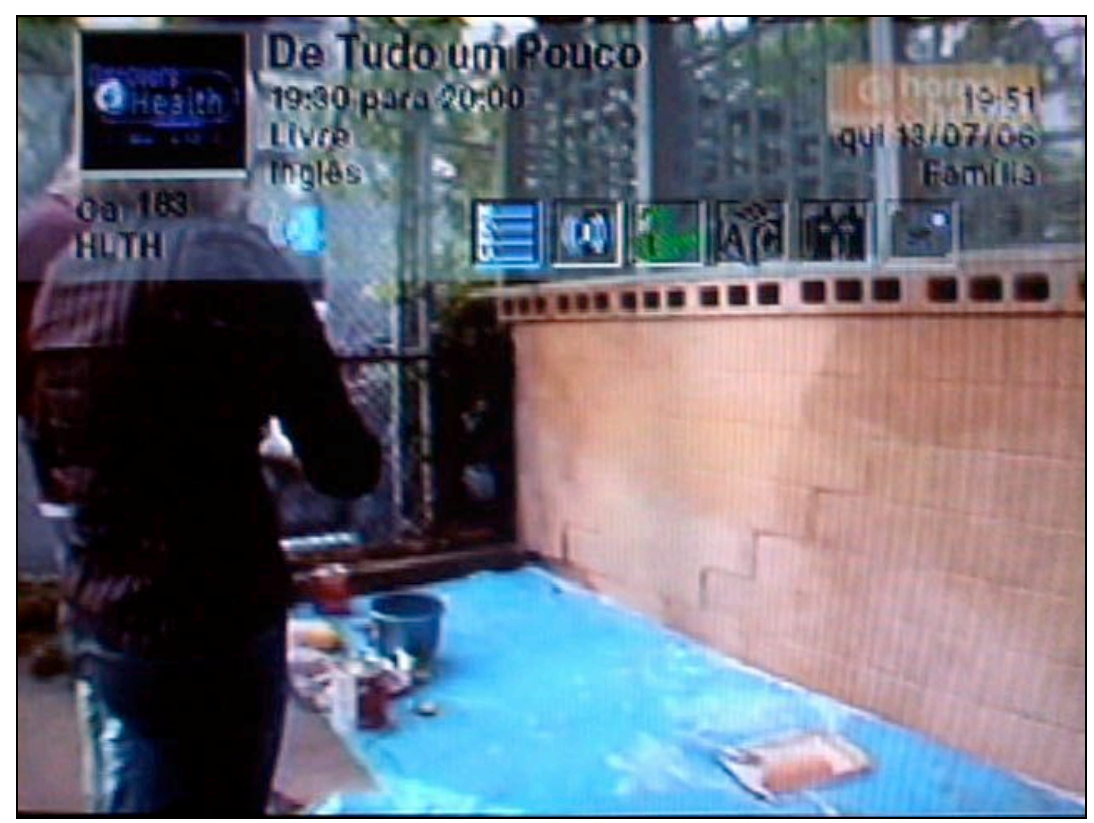

Figura 4-27 - Tarja de informações da plataforma DirecTV

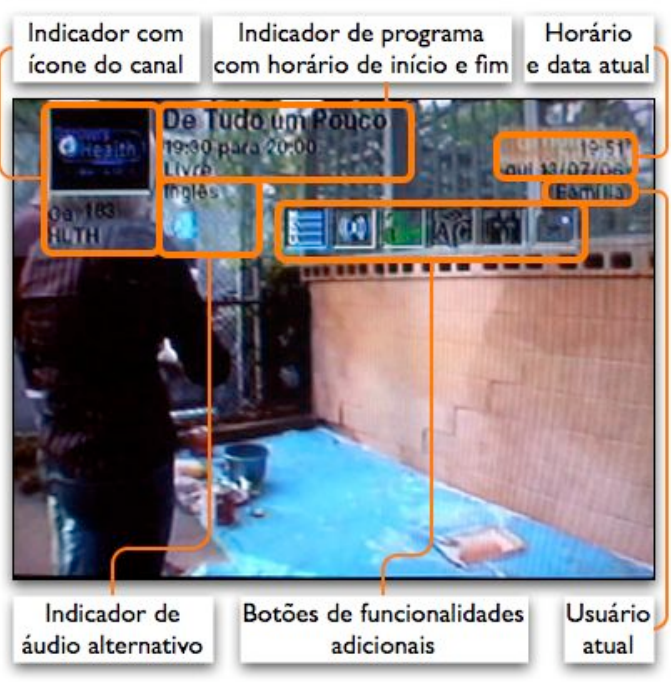

Figura 4-28 - Detalhes da tarja de informações da plataforma DirecTV
A tarja de informações da DirecTV aparece na parte superior da tela com transparência sobre o vídeo (Figura 4-27 e Figura 4-28). É bem maior do que as tarjas de outras plataformas, cobrindo aproximadamente $1 / 3$ da tela. O nível de transparência da tarja permite ver o conteúdo por trás da tarja, mas dificulta muito a leitura do seu conteúdo.

Apresenta um ícone do canal, mas não seu nome, apenas uma sigla de 4 caracteres. Duas particularidades desta plataforma são que sua tarja informa qual usuário está utilizando o sistema (no caso um usuário chamado Família) e a presença de um pequeno menu de opções com 6 botões. Nesta a tarja não exibe as informações de outro 
horário ou de outro canal, somente do canal sintonizado e para vê-las é necessário ir ao guia de programação.

As opções de legenda e áudio alternativo são acionadas por uma tecla dedicada no controle remoto. O áudio utilizado tem um indicador na tarja, mas o indicador das legendas aparece somente quando esta tecla é acionada. Um dos botões do menu de opções da tarja também controla o áudio, mas não há um botão para legendas.

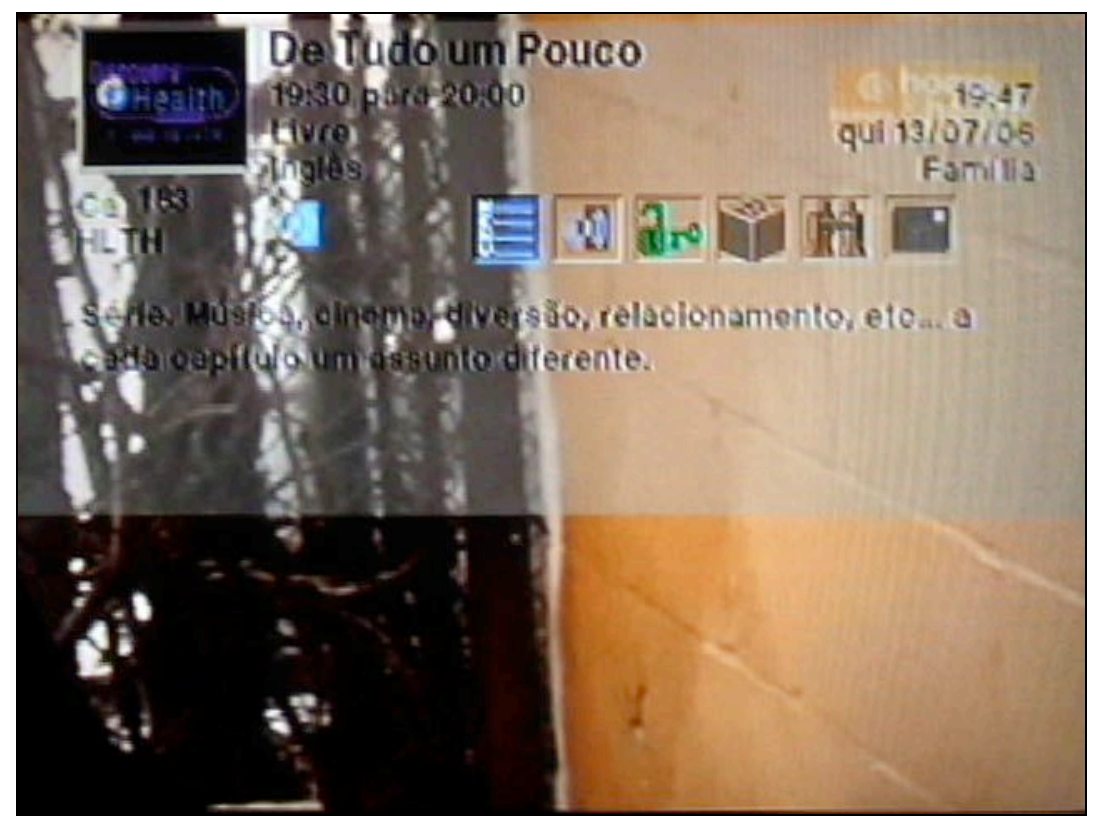

Figura 4-29 - Tarja com sinopse da plataforma DirecTV

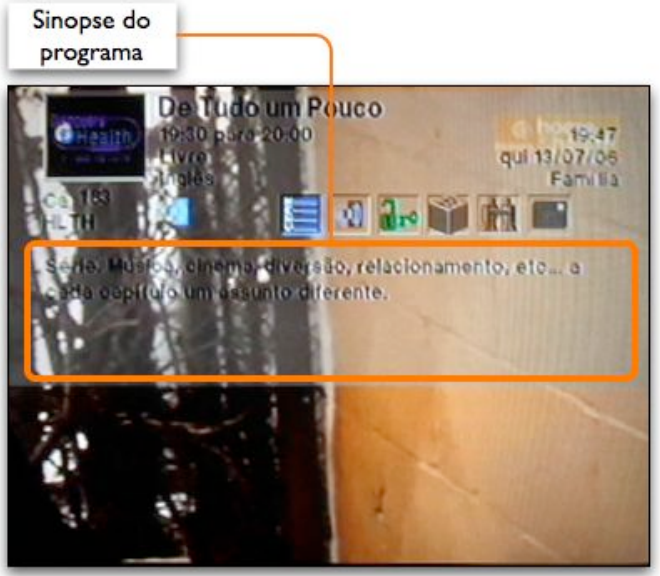

Figura 4-30 - Detalhe da tarja com sinopse da plataforma DirecTV
A tarja de sinopse desta plataforma é uma ampliação da tarja normal (Figura 4-29 e Figura 4-30), que passa a ocupar mais da metade da tela. Novamente o excesso de transparência dificulta a leitura. Uma vez acionada, a tarja permanece nesta forma mesmo quando se muda de canal. 


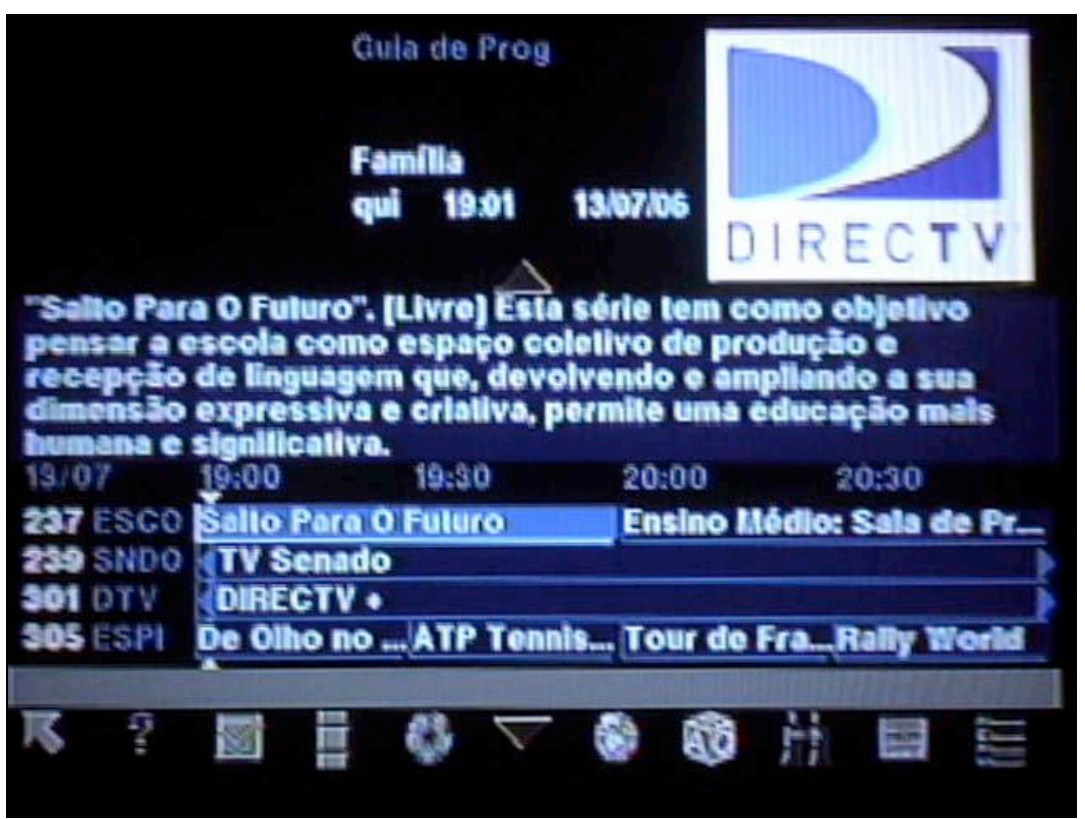

Figura 4-31 - Guia de programação com sinopse da plataforma DirecTV

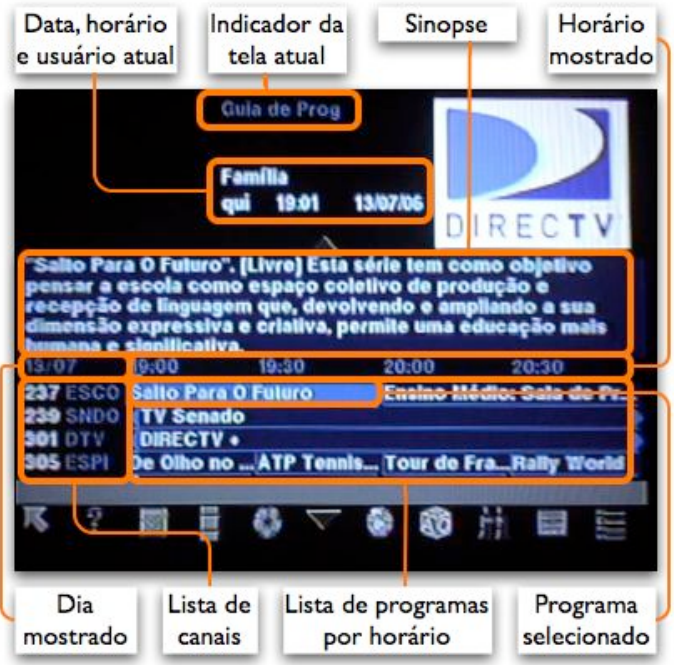

Figura 4-32 - Detalhes do guia de programação com sinopse da plataforma DirecTV
O guia de programação da DirecTV tem quatro formatos possíveis. $\mathrm{O}$ primeiro formato contém uma sinopse do programa selecionado, além de uma lista com 4 canais e sua programação na hora atual e na próxima (Figura 4-31 e Figura 4-32). Nesta tela não há áudio.

Mesmo utilizando uma fonte de tamanho pequeno esta tela consegue mostrar poucas informações, e não utiliza o terço superior da tela. Os nomes dos programas também são

freqüentemente truncados e os canais são identificados pelo número e por uma sigla de 4 caracteres. Para navegar entre os canais o usuário pode usar as setas verticais (o teclado numérico também funciona). Para navegar entre os horários o usuário deve utilizar as setas horizontais.

Quando o usuário chega na primeira linha da tabela e continua subindo ele vai para uma seta que está acima da sinopse. Se ele continuar subindo (ou 
apertar a tecla $\mathrm{OK}$ ) os canais da lista são rolados para baixo e aparece um novo canal no topo.

Na direção oposta (para baixo) o mesmo acontece, mas se estiver na altura da seta inferior e utilizar as setas horizontais ele vai acessar os ícones para algumas funcionalidades disponíveis nesta tela (sair, ajuda, filtros, busca, pesquisa e menu de configuração).

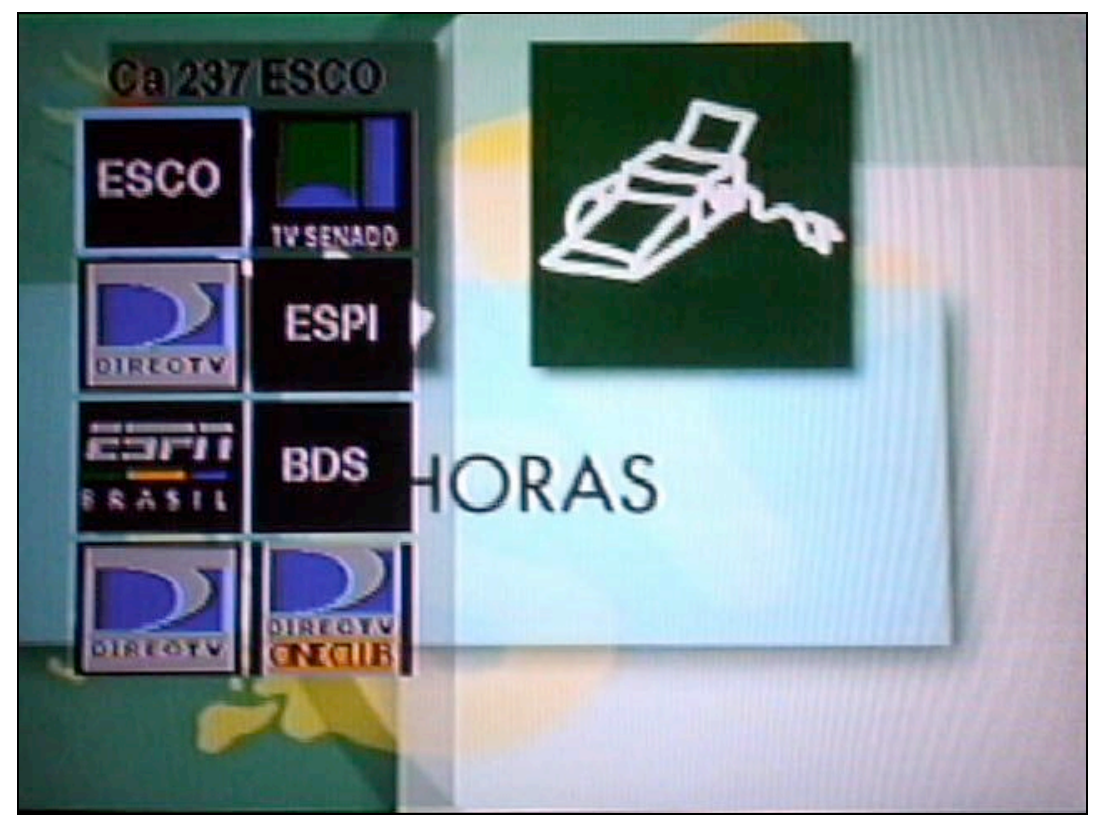

Figura 4-33 - Guia de programação por ícones da plataforma DirecTV

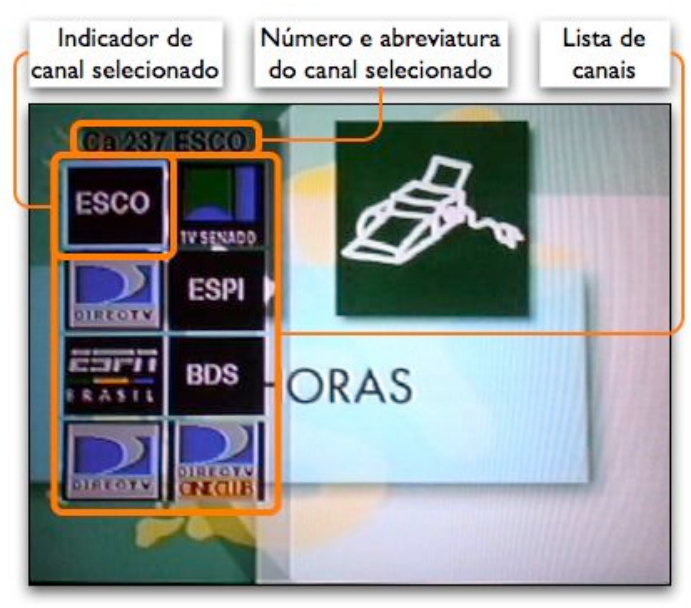

Figura 4-34 - Detalhes do guia de programação por ícones da plataforma DirecTV
Dos quatro formatos do guia de programação desta plataforma, três utilizam o paradigma de uma lista de canais com horários. O quarto formato, no entanto, utiliza ícones ao invés de uma descrição textual (Figura 4-33 e Figura 4-34).

Nesta plataforma a implementação não apresenta informações sobre programação nem horário, e portanto não é necessariamente um guia de programação, mas pode ser visto 
como uma forma alternativa de seleção de canais. Esta plataforma não tem uma tela inicial (portal) nem tem aplicativos.

\section{Dispositivos da Plataforma}

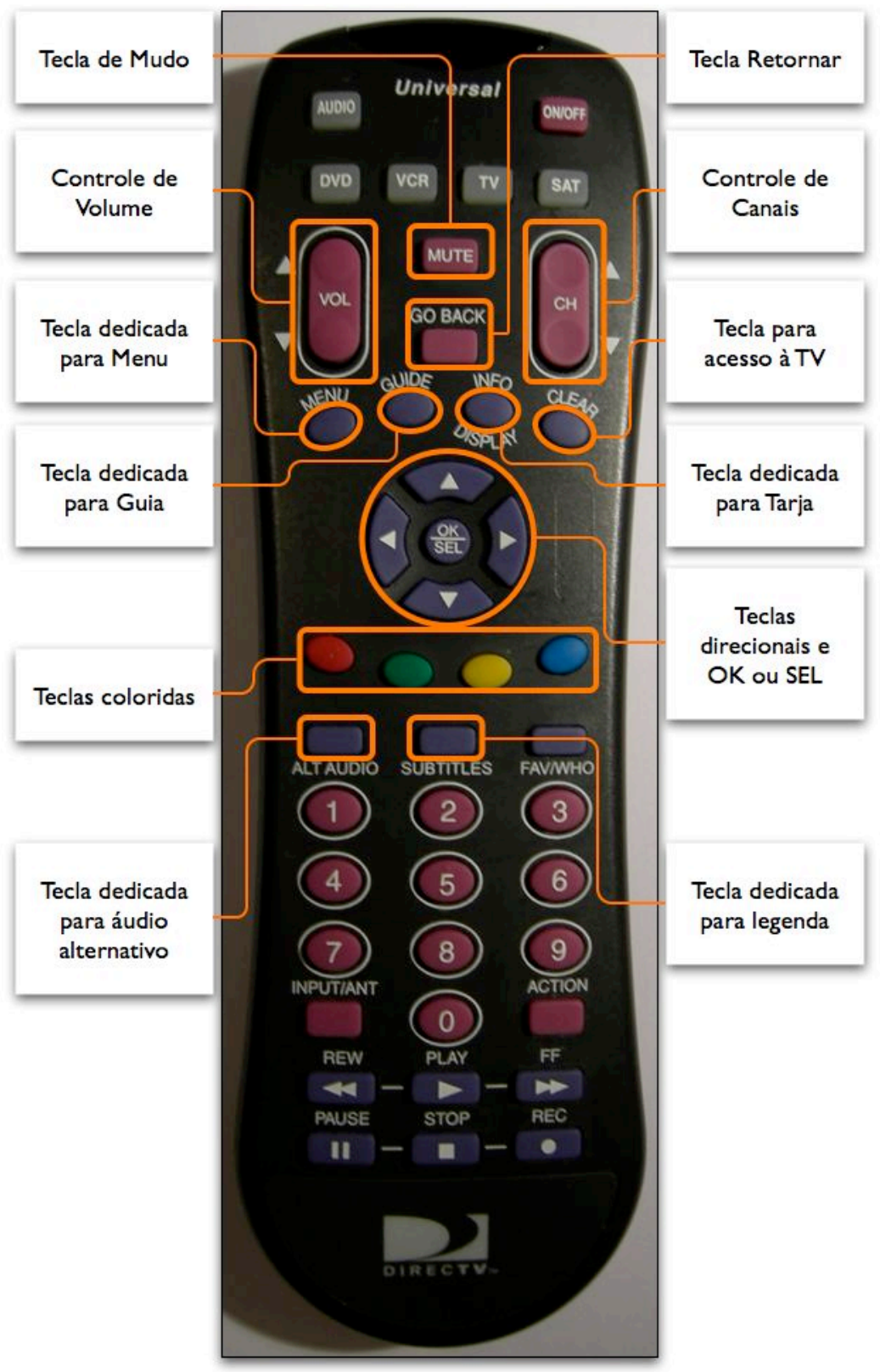

Figura 4-35 - Controle remoto da plataforma DirecTV

No controle remoto da DirecTV (Figura 4-35) as teclas de controle de canais, volume e mudo estão agrupadas por proximidade e cor. Logo abaixo ficam 4 teclas com funções dedicadas para acesso ao menu, ao guia de progra- 
mação, à tarja informativa e a tecla Clear que é um atalho para voltar ao canal sintonizado (caso se esteja no guia de programação, por exemplo).

As quatro setas direcionais têm o arranjo tradicional, com a tecla de confirmação no meio. Devido à cor e proximidade com as teclas dedicadas elas formam um conjunto. A tecla de confirmação tem o rótulo OK/SEL provavelmente porque em partes diferentes do sistema a tecla de confirmação tem nomes distintos. A tecla Volta (Go Back) está distante e em cor diferente das teclas direcionais, o que dificulta sua associação às funções de navegação.

As teclas coloridas não têm função nesta plataforma. Abaixo delas estão duas teclas dedicadas à troca de legenda e de áudio alternativo.

No total são 46 teclas, todas com rótulos em inglês.

\section{Navegação da Plataforma}

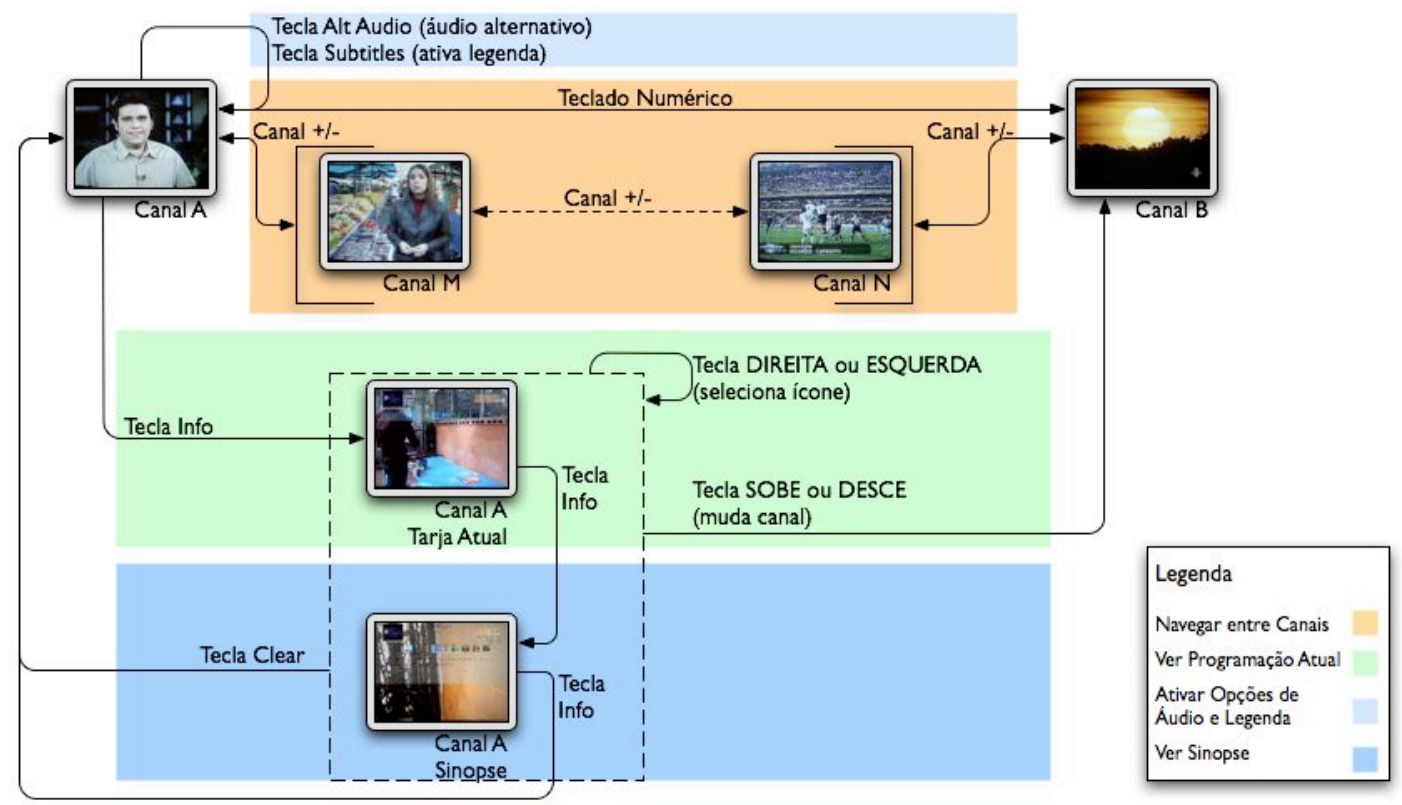

Figura 4-36 - Navegação de TV da plataforma DirecTV

A tarja de informações desta plataforma (Figura 4-27) não permite ver informações de outro canal ou horário e na prática tanto as setas verticais quanto as teclas de controle de canal servem para trocar de canal.

A tecla Info abre a tarja de informações e, se for pressionada novamente, aumenta a tarja de informações e mostra a sinopse (Figura 4-29). A tarja de 
sinopse aberta é um estado da tarja que se mantém mesmo quando se muda de canal. Para fechar a tarja de sinopse é utilizada a tecla Info novamente. A tecla Clear fecha as duas tarjas.

Esta plataforma não tem uma tela para escolha de legenda e áudio alternativo. Para isto existem duas teclas dedicadas no controle remoto.

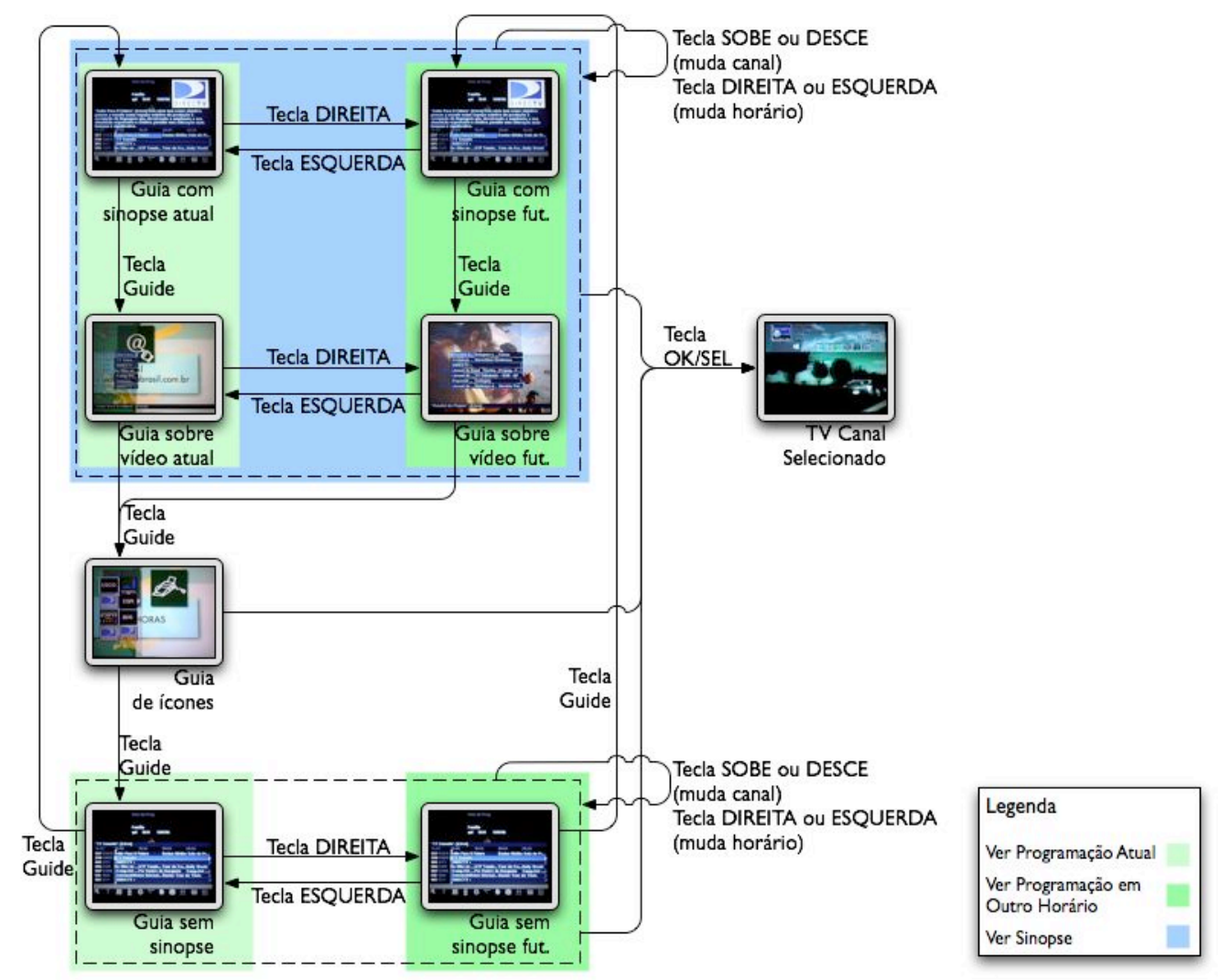

Figura 4-37 - Navegação do guia da plataforma DirecTV

Ao pressionar a tecla Guide nesta plataforma o usuário vai para a tela de guia de programação com sinopse (Figura 4-31), que é uma das quatro telas de guia de programação da plataforma. Pressionando a tecla Guide novamente o usuário passa pelas outras três telas e retorna para esta. Não existe uma forma de fazer este circuito no sentido inverso.

Em três destas telas o usuário pode navegar pelos canais e horários de forma semelhante. A diferença é que a primeira está sobre um fundo preto, a outra é sobre o vídeo, e a terceira apresenta mais canais da programação, mas não tem a sinopse. A outra tela (Figura 4-33) apresenta apenas duas colunas 
de ícones sobre o vídeo, não sendo um guia de programação propriamente dito.

\subsubsection{Plataforma TVA Digital}

\section{Descrição da Plataforma}

A TVA Digital é uma plataforma de TV digital a cabo, que tem aproximadamente 60 canais.

Além das características da plataforma anterior (guia de programação, tarja informativa, etc.) esta plataforma tem uma estrutura de navegação em menus de navegação onde o vídeo fica em $1 / 4$ de tela e o restante da tela tem ícones de navegação pelos canais, agrupados por temas. 
Mapa de Navegação da Plataforma

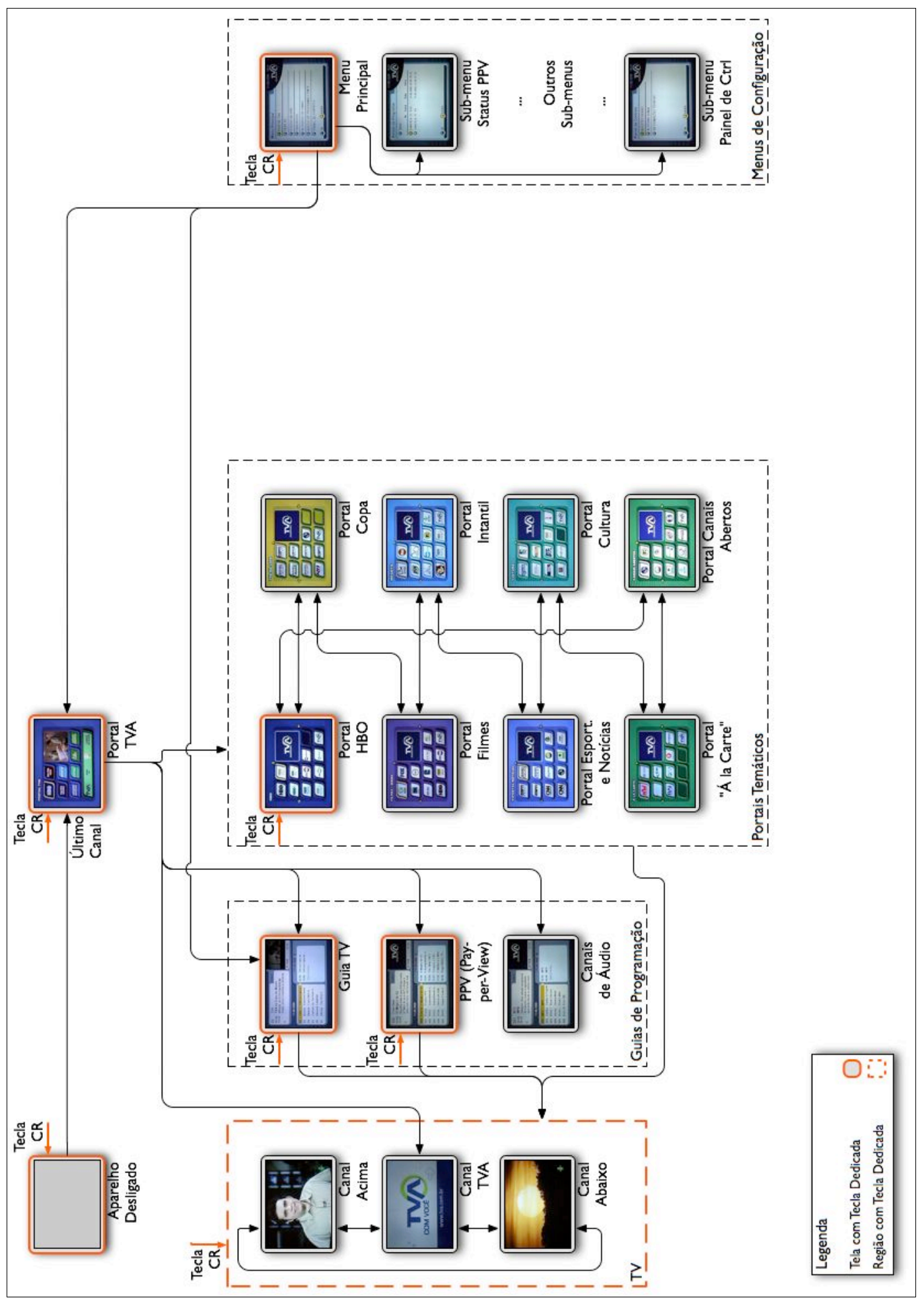

Figura 4-38 - Mapa de navegação da plataforma TVA Digital 
Esta plataforma apresenta um mapa de navegação baseado em menus e botões na interface gráfica. Este é um paradigma diferente do utilizado nas plataformas anteriormente apresentadas e mais próximo do paradigma das outras plataformas presentes nesta análise.

Ao ser ligada, a TV entra na tela do Portal TVA (Figura 4-43), apresenta o último canal sintonizado em 1 / 4 de tela e 12 botões para acesso aos guias de programação e aos portais temáticos. Entre os canais de TV esta plataforma contem algumas rádios (Bandeirantes $\mathrm{AM}$, por exemplo). Isto causa um certo estranhamento pois quando este "canal" é sintonizado a tela do televisor fica preta (apagada).

Esta plataforma tem três guias de programação, um para os canais normais, outro para canais Pay-per-view e outro para canais de áudio. Estes três guias apresentam a mesma interface, mas com faixas de canais diferentes (os Pay-per-view ficam na faixa de 100 e os canais de áudio ficam na faixa de 200). Os canais de áudio não incluem os canais de rádios citados acima.

Os portais temáticos têm aparência muito semelhante à tela inicial mas seus botões são atalhos para os canais relativos ao tema do portal (filmes, infantil, etc.).

O menu de configuração só é acessível por uma tecla dedicada no controle remoto. 


\section{Telas da Plataforma}

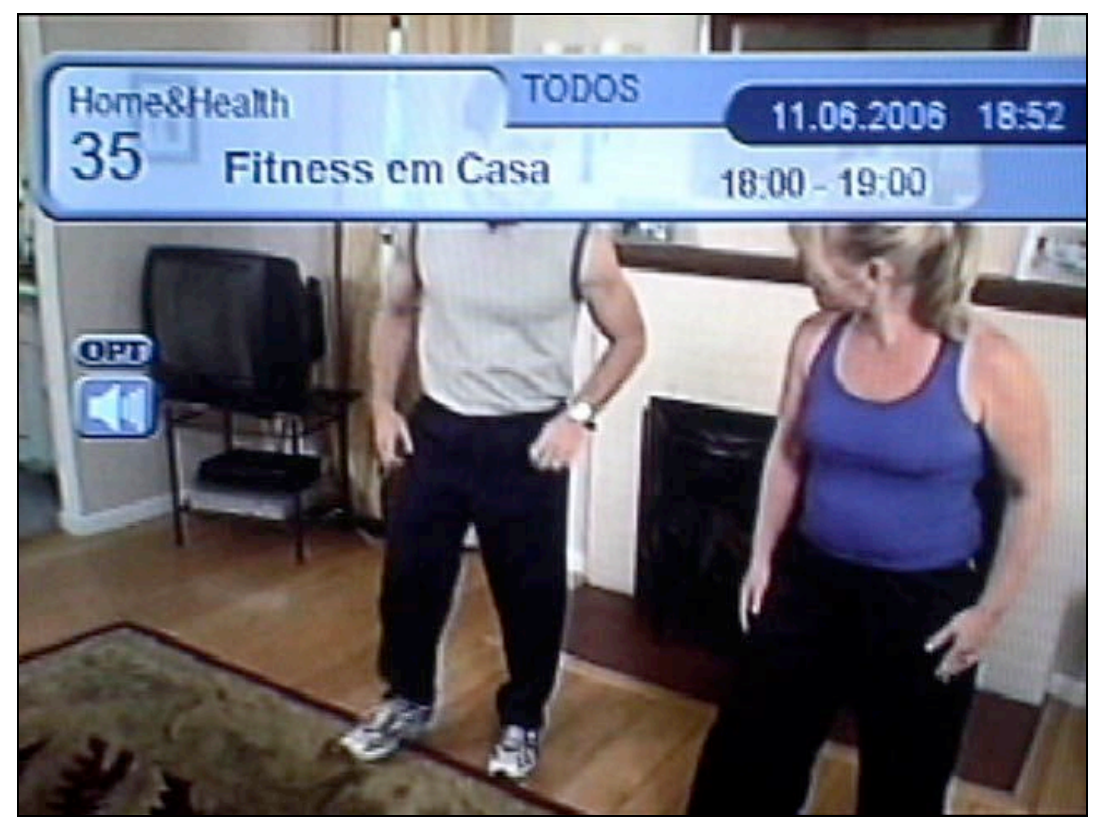

Figura 4-39 - Tarja de informações da plataforma TVA Digital

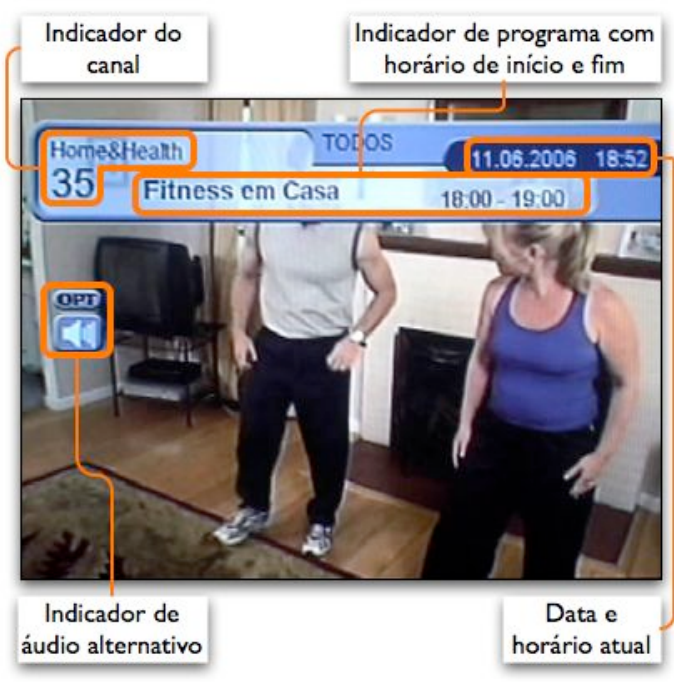

Figura 4-40 - Detalhes da tarja de informações da plataforma TVA Digital
A tarja de informações desta plataforma também aparece na parte superior da tela, mas é bem menor e menos transparente, $\mathrm{o}$ que facilita a leitura. Apresenta as informações básicas de canal e programa com horário de início e fim, assim como data e horário atual (Figura 4-39 e Figura 4-40). Nesta tarja é possível verificar os programas em outros canais (pelas setas verticais) e no horário seguinte (pelas setas horizontais).

A troca de canais é demorada (aproximadamente 2 segundos), mas a navegação pelas informações da tarja é praticamente instantânea e portanto ela se torna uma forma mais eficiente para se navegar pelos canais. Ao se selecionar um outro canal e apertar a tecla de confirmação ele é sintonizado. Não e- 
xiste, no entanto, nenhum indicador nesta tela da possibilidade de navegação entre os canais e horários pelas setas direcionais.

Há um indicador de áudio alternativo, mas ele fica separado da tarja de navegação. Uma vez que a imagem de fundo está em movimento a falta de continuidade visual entre a tarja (que sempre aparece) e o indicador de áudio alternativo pode ser um problema.

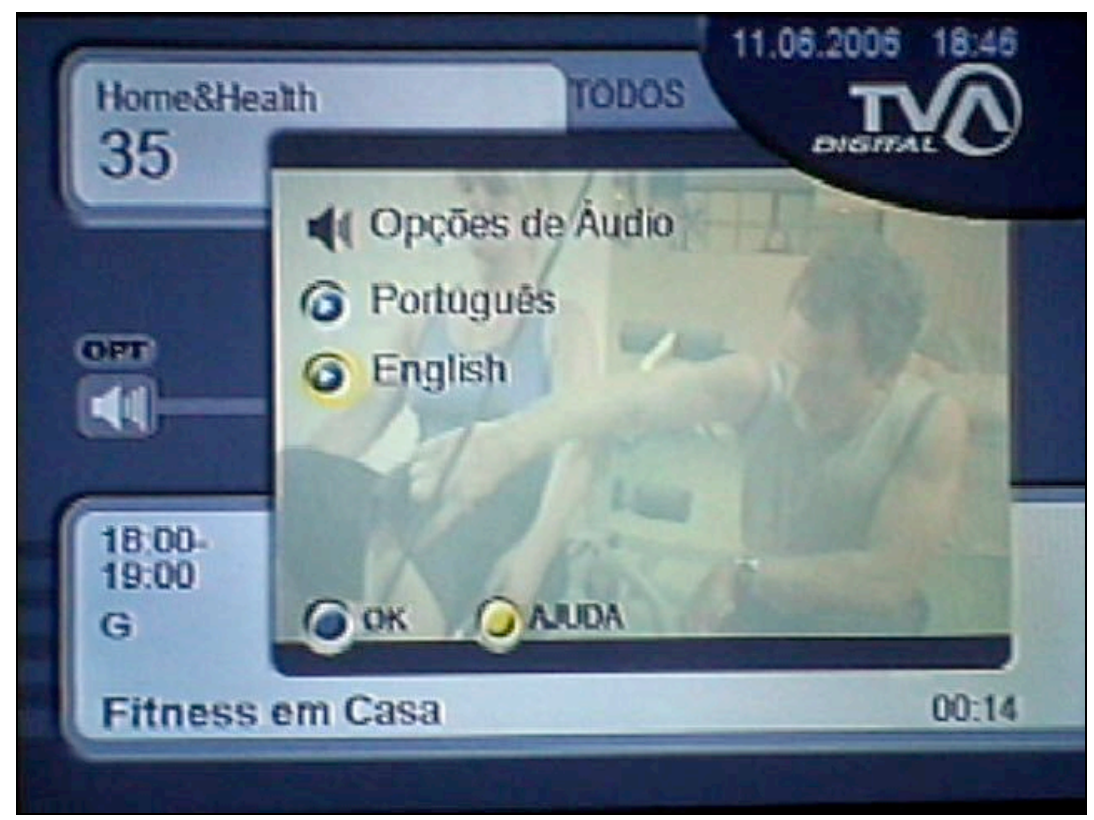

Figura 4-41 - Opções de legenda e áudio alternativo da plataforma TVA Digital

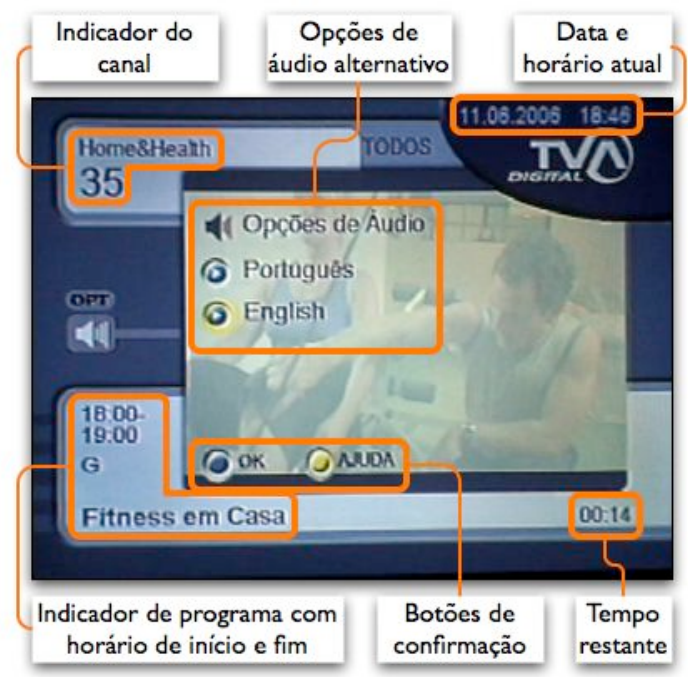

Figura 4-42 - Detalhes das opções de legenda e áudio alternativo da plataforma TVA Digital
A tela com opções de legenda e áudio alternativo (Figura 4-41 e Figura 4-42) tem uma borda sem transparência e apresenta as opções no centro da tela, sobre um fundo semitransparente. A seleção da opção desejada é feita através das setas direcionais e da tecla de confirmação. 
A tela de sinopse é idêntica à tela de opções de legenda e áudio alternativo, mas ao invés de mostrar as opções aparece o texto da sinopse. Além do texto da sinopse a única informação adicional nesta tela em relação à tarja de informações é o tempo restante do programa, que aparece no canto direito inferior.

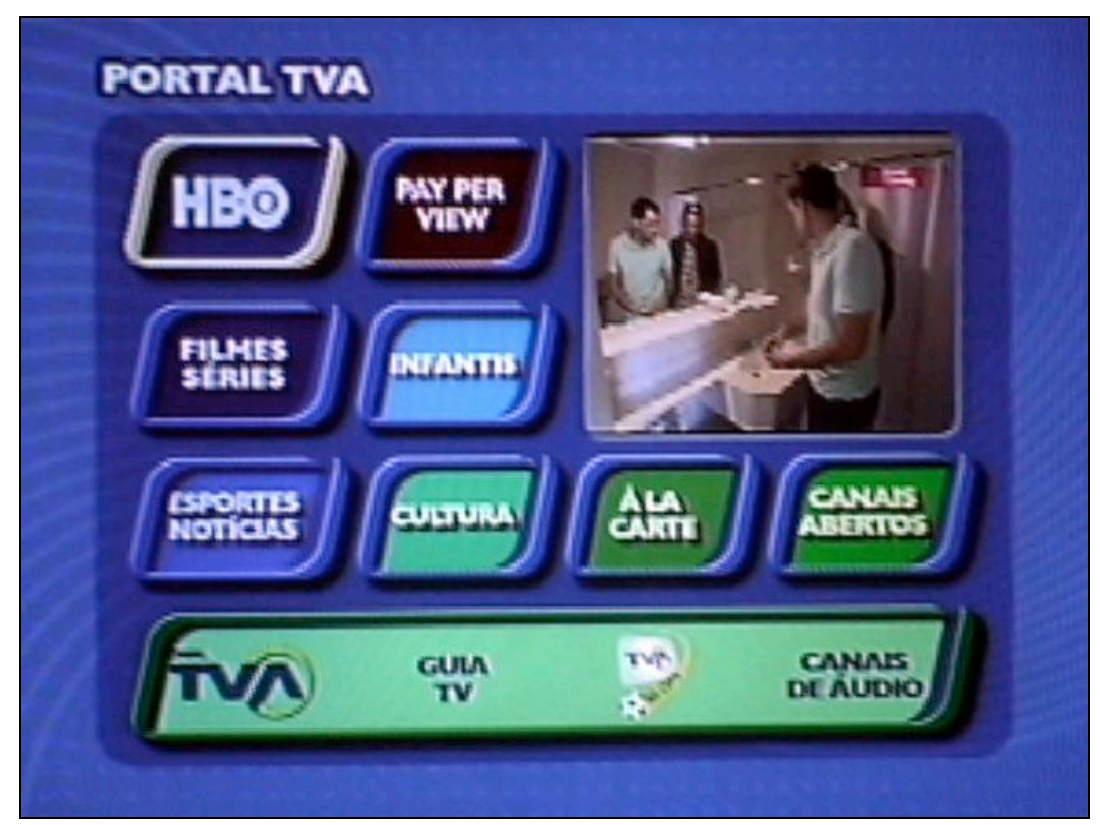

Figura 4-43 - Tela inicial da plataforma TVA Digital

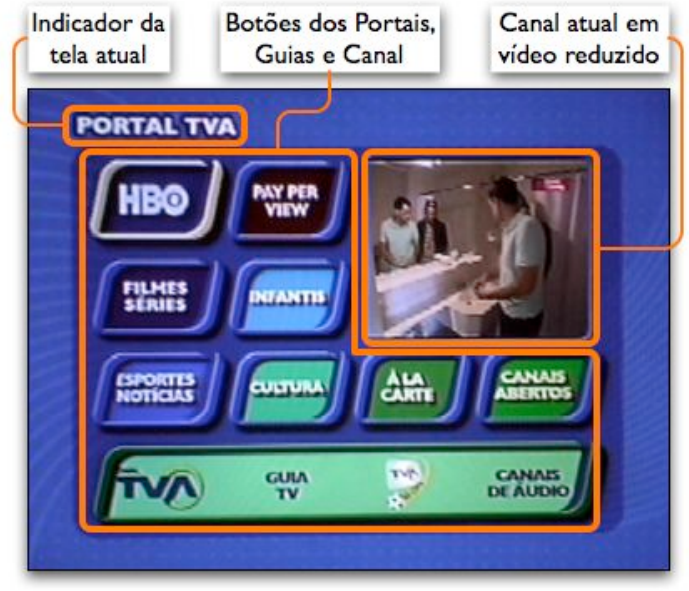

Figura 4-44 - Detalhes da tela inicial da plataforma TVA Digital
A tela Portal TVA é o ponto de partida para a navegação pelo sistema. Ela apresenta doze botões arranjados em linhas e colunas, o que facilita a navegação pelas setas direcionais (Figura 4-43 e Figura 4-44). Apesar de estarem juntos visualmente, os elementos da linha inferior (Canal TVA, Guia TV, TVA Copa e Canais de Áudio) são quatro botões distintos e não tem uma relação entre si.

Oito dos doze botões levam para portais temáticos (filmes, infantil, etc.). Os quatro botões restantes levam para o guia de programação (Guia TV), os 
canais de áudio (Canais de Áudio), os canais de Pay-per-view (Pay per view) e o canal informativo da TVA (Canal TVA). Não existe uma relação entre o formato e posição do botão e o seu destino.

O vídeo desta tela é o último canal selecionado. Ao selecionar e confirmar um dos botões da tela o usuário vai para a tela de destino.

Os portais temáticos têm arranjo semelhante ao Portal TVA, mas os botões são atalhos para os canais referentes ao tema do portal (exemplo: o portal de filmes tem ícones dos canais de filmes).

Nos portais temáticos o comportamento dos botões se modifica. Ao selecionar e confirmar um dos canais ele não é apresentado em tela cheia, mas este canal aparece na área de preview que ocupa o quadrante superior direito e o indicador de seleção (borda amarela) muda da cor amarela para laranja. Para ir para o canal selecionado é necessário pressionar a tecla de confirmação novamente. Se por um lado a funcionalidade de preview é interessante, a mudança de comportamento sem um indicador visual causa um certo estranhamento. 


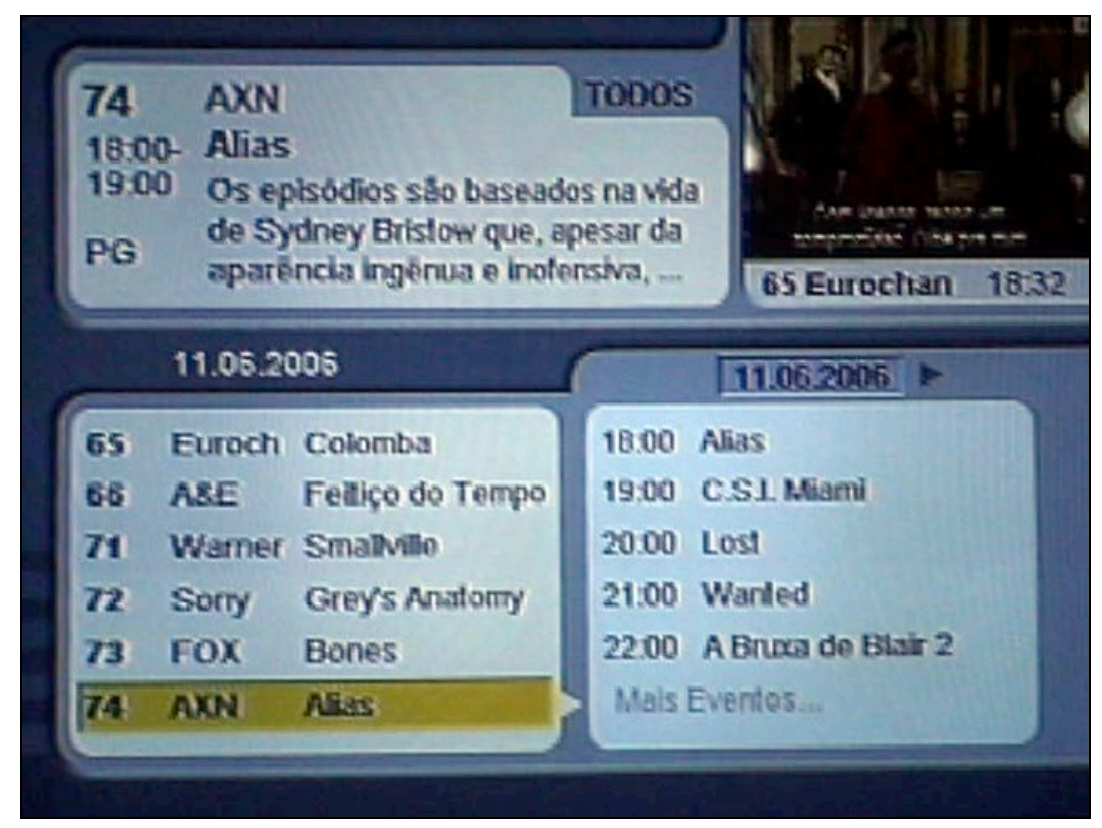

Figura 4-45 - Guia de programação da plataforma TVA Digital

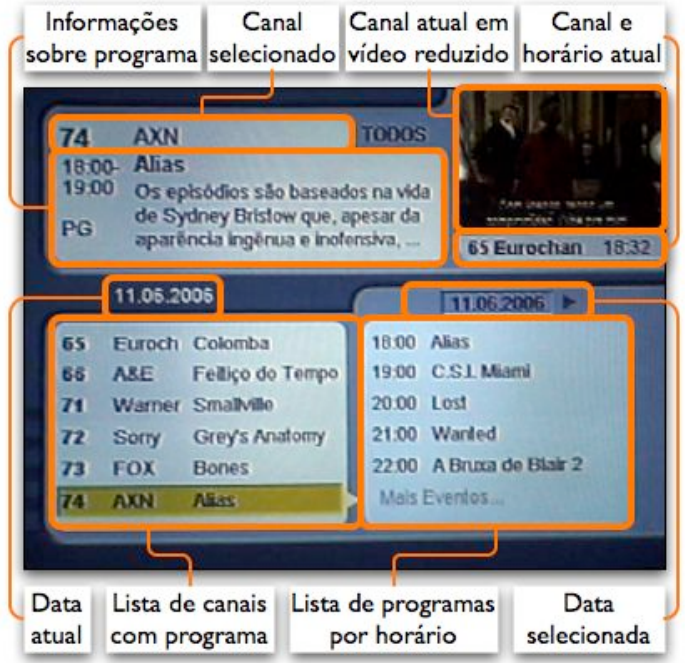

Figura 4-46 - Detalhes do guia de programação da plataforma TVA Digital
O guia de programação da TVA Digital segue um paradigma diferente do utilizado na plataforma anterior. Ao invés de uma tabela com um canal por linha e os horários nas colunas apresenta dois painéis, $\mathrm{o}$ da esquerda com a lista de canais e o da direita com a lista de programas por horário para um canal específico (Figura 4-45 e Figura 4-46).

Na parte superior da tela

estão as informações sobre o canal e programa selecionados, que incluem uma parte da sinopse do programa. No canto superior direito fica a imagem reduzida do canal atual.

Quando o guia de programação é aberto, ele está com o canal atual selecionado. A navegação pelos canais é feita pelas setas verticais e o painel de informações é atualizado à medida que os diferentes itens são selecionados. Para selecionar um programa em outro horário é necessário ir para o 
Para selecionar um programa em outro horário é necessário ir para o painel da direita, utilizando a seta para a direita. O cursor passa para o outro painel e então as setas verticais selecionam os diferentes programas naquele canal. Para voltar para a seleção de canais utiliza-se a seta para a esquerda. Para ver o programa em um outro dia, o usuário deve subir até o topo da lista de horários. Ao subir mais um item selecionará a data e então pode modificá-la por meio das setas horizontais (o cursor seleciona o campo da data selecionada).

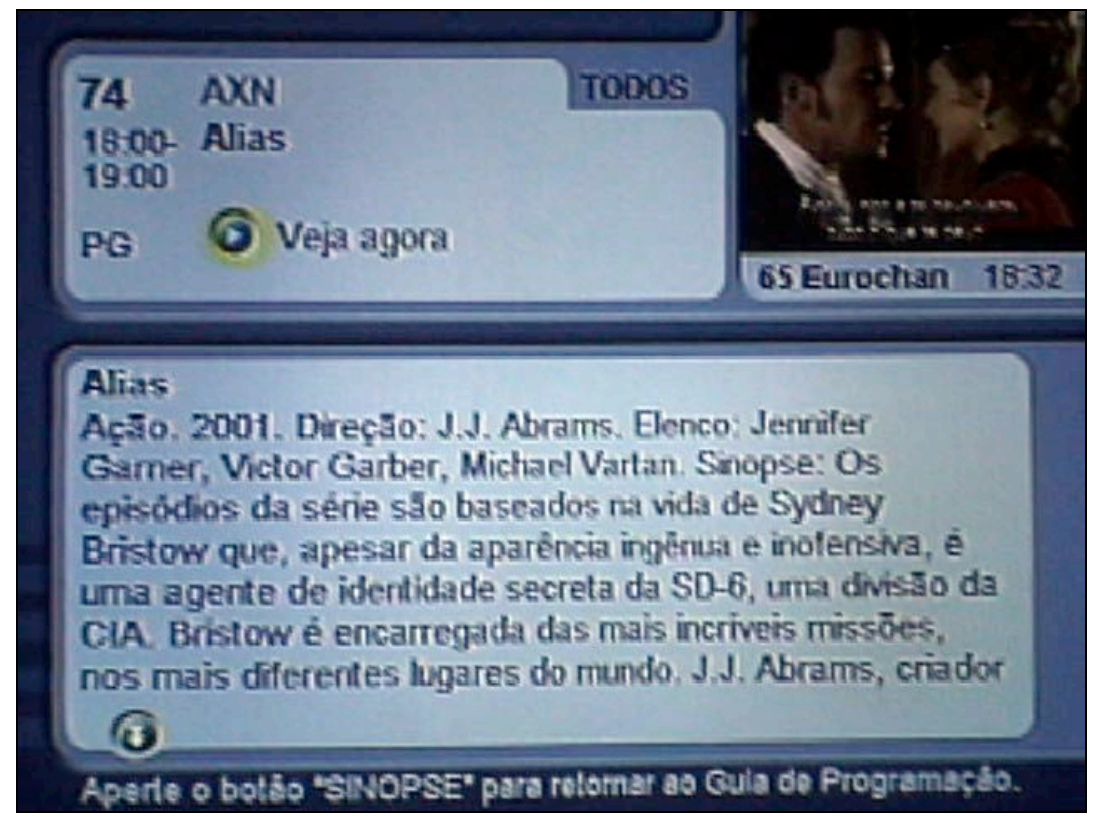

Figura 4-47 - Tela de sinopse da plataforma TVA Digital

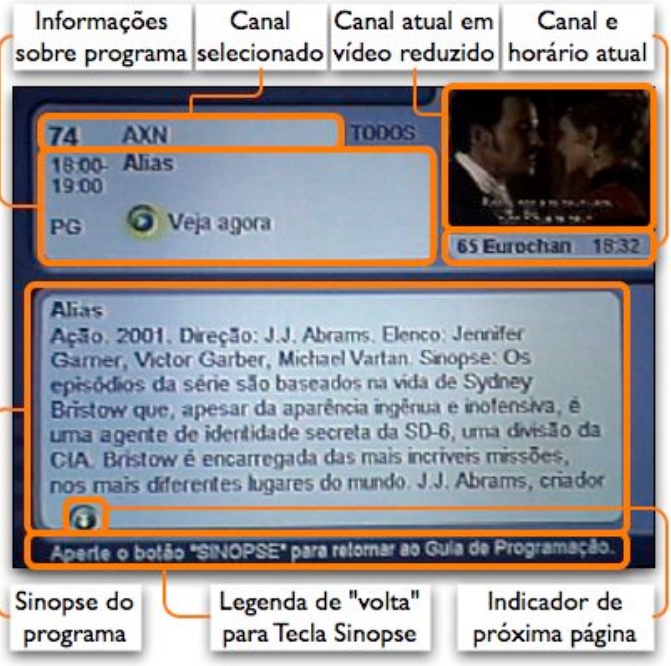

Figura 4-48 - Detalhes da tela de sinopse da plataforma TVA Digital
Ao confirmar a seleção de um canal ou programa no guia de programação o usuário vai para a tela de sinopse (Figura 4-47 e Figura 4-48). Nesta tela os painéis inferiores são substituídos pelo texto da sinopse. Caso a sinopse seja muito grande ela pode ocupar mais de uma tela. Para trocar de página o usuário pode utilizar uma tecla dedicada no controle remoto ou utilizar as setas direcionais e a tecla de confirmação no próprio botão da tela. 
Como não há uma tecla Volta no controle remoto, para retornar ao guia de programação o usuário deve utilizar a tecla Sinopse, conforme indicado na parte inferior tela.

Caso o programa selecionado seja no horário atual uma nova confirmação neste tela irá levar o usuário para o canal (e programa) selecionado. Este comportamento é semelhante às duas etapas (preview e confirmação) da navegação nos portais temáticos.

Caso o programa selecionado seja em outro horário ou data uma nova confirmação irá agendar o programa. O agendamento de um programa traz um aviso à tela quando ele estiver prestes a começar.

Um detalhe interessante é que se o usuário estiver no guia de programação e pressionar a tecla de confirmação 2 vezes rapidamente irá direto para o programa selecionado de forma semelhante ao duplo clique no paradigma WIMP, que muitas vezes tem a função de atalho para a ação mais provável sobre um objeto.

Esta plataforma não tem aplicativos. 


\section{Dispositivos da Plataforma}

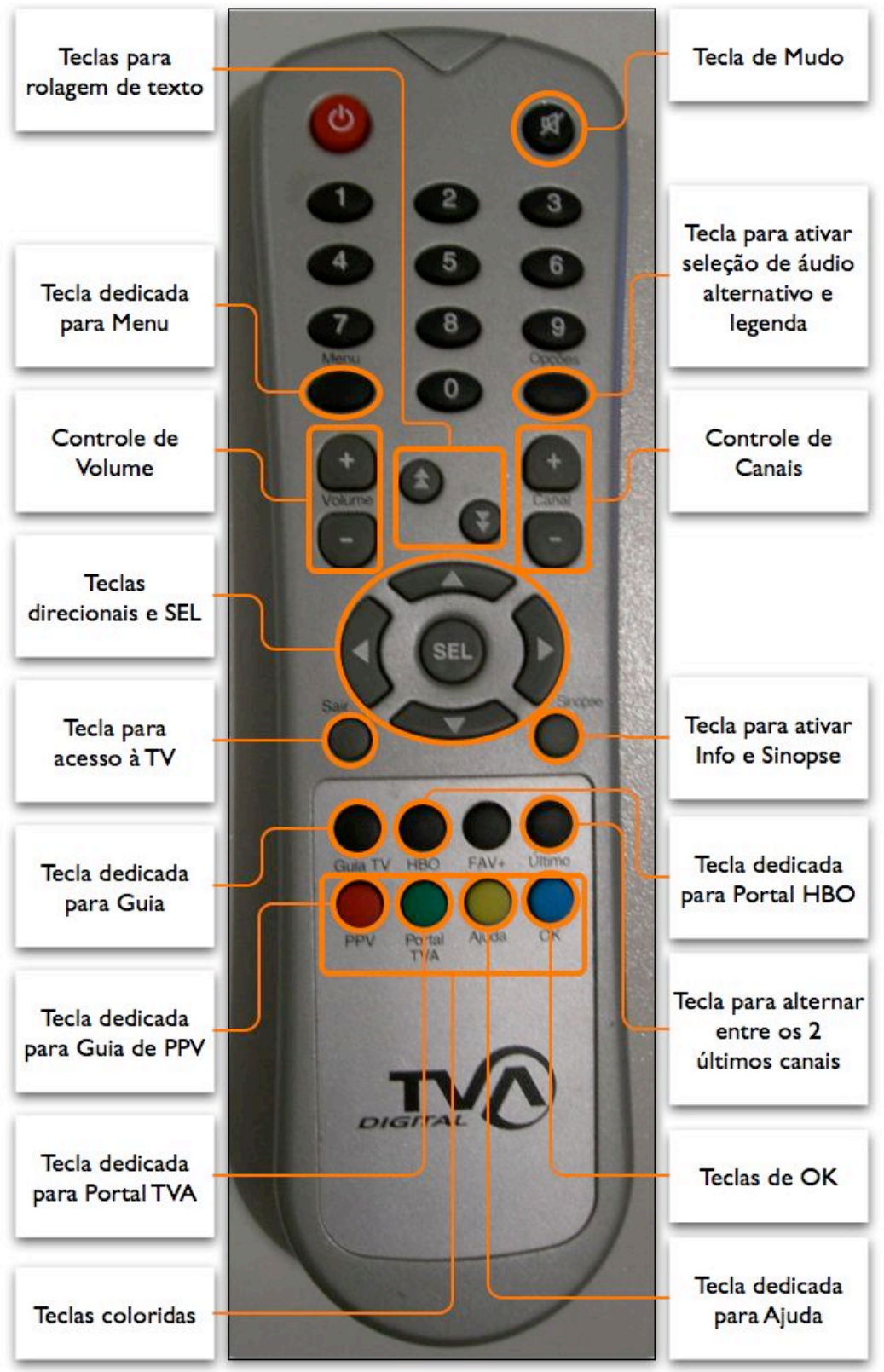

Figura 4-49 - Controle remoto da plataforma TVA Digital

O controle remoto da TVA Digital (Figura 4-49) é o único que tem teclas específicas para rolagem de texto, que ficam entre as teclas de controle de volume e canal.

Acima das teclas de controle de volume está a tecla para ativar o menu de configuração, que é a única forma para se chegar a esta tela. Acima das teclas de controle de canal está a tela para abrir as opções legenda e áudio alternati- 
vo, mas esta tela também é acessível pela tecla de confirmação, que nesta plataforma é chamada de SEL.

Abaixo das setas direcionais à esquerda está a tecla para acesso à TV (Sair) e abaixo à direita está a tecla para acesso à sinopse (Sinopse). Este controle remoto não tem tecla para voltar o que obriga a utilização de algumas teclas para ativar e desativar uma função (como é o caso da tecla sinopse).

As oito teclas na parte de baixo do controle remoto formam dois grupos visuais, um de quatro teclas pretas e outro de quatro teclas coloridas, mas em termos de funcionalidade o agrupamento é outro. As quatro teclas da esquerda são atalhos para telas da interface (guia de programação e 3 portais) enquanto as outras quatro teclas têm funções variadas. Uma delas serve para controlar favoritos, a outra tem função de troca entre os dois últimos canais, a tecla amarela tem função de Ajuda e a tecla azul tem função de OK.

Não fica claro quando um aplicativo deve utilizar a tecla OK (azul) ou a tecla SEL (no centro das setas direcionais). Caso um aplicativo já utilize a tecla azul para outra função nesta plataforma haverá uma ambigüidade de significados.

No total o controle tem 35 teclas e os rótulos são em português. 


\section{Navegação da Plataforma}

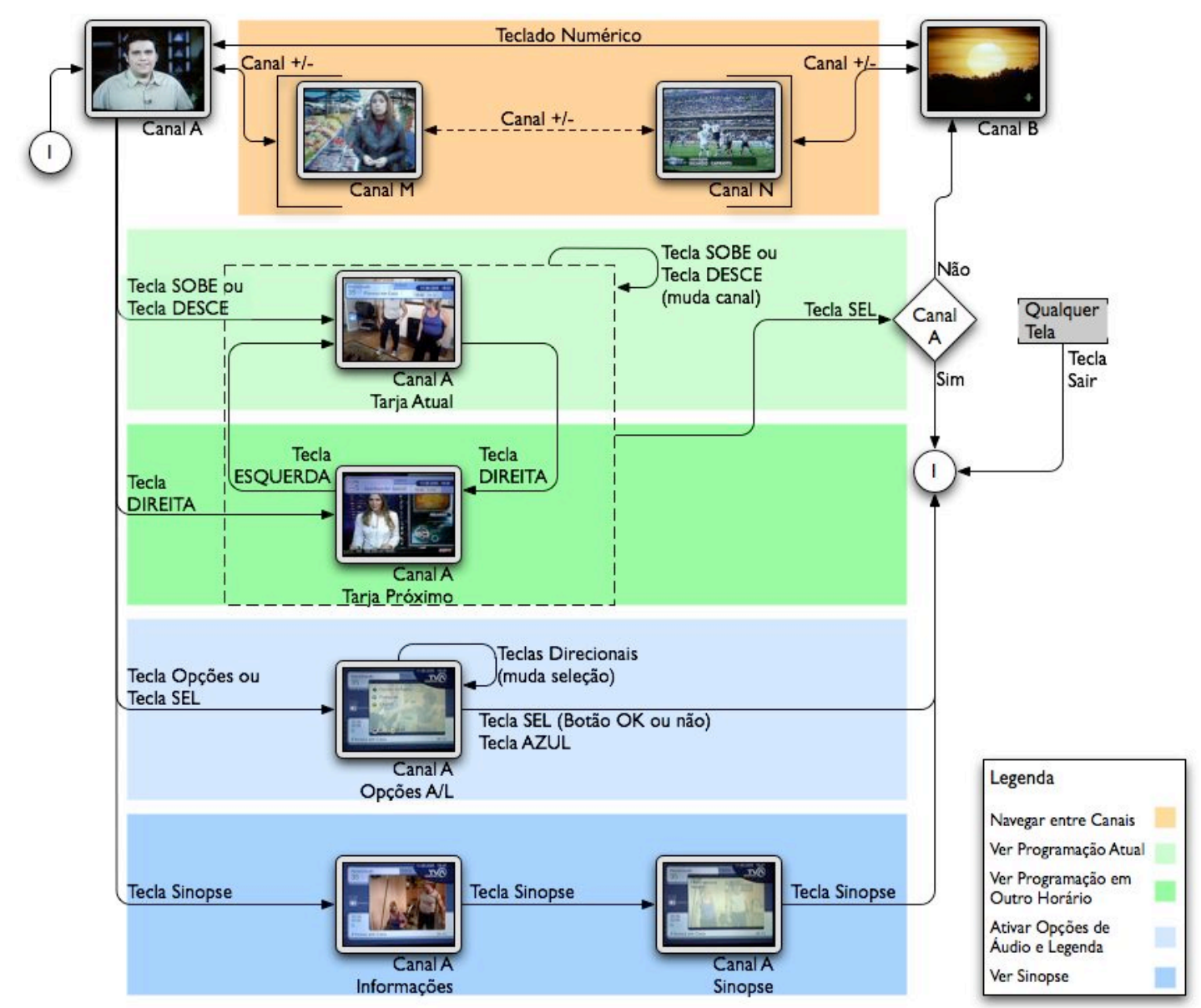

Figura 4-50 - Navegação de TV da plataforma TVA Digital

A tarja de informações desta plataforma (Figura 4-39) permite ver as informações do programa atual e seguinte de qualquer canal. Para ativá-la são utilizadas as setas verticais, que mostram o programa atual no horário atual. Utilizando a seta para a direita a tarja abre mostrando o programa seguinte do canal atual. A seta para a esquerda não tem efeito.

Com a tarja aberta as setas verticais mudam de canal, a seta para a esquerda mostra o horário atual e a seta para a direita mostra o próximo horário. Ao pressionar a tecla de confirmação o usuário é levado para o canal selecionado na tarja, independentemente de estar mostrando a programação atual ou a próxima. O guia de programação se comporta de forma diferente se for um programa atual ou futuro. 
Com a tarja desativada, a tecla de confirmação tem a mesma função da tecla de Opções, que leva para a tela de escolha de opções de legenda e áudio alternativo (Figura 4-41). Nesta tela as teclas direcionais são usadas para selecionar os botões e a tecla de confirmação aplica a escolha feita. A tecla azul é utilizada como um atalho para a tecla de confirmação.

A tecla Sinopse leva para uma tela de informações com aparência muito semelhante à tela de sinopse mas sem o texto da sinopse sobre o vídeo. Pressionando novamente a tecla aparece o texto de sinopse e pressionando mais uma vez volta para a tela da TV. Em qualquer situação a tecla Sair pode ser utilizada como um atalho para a tela da TV.

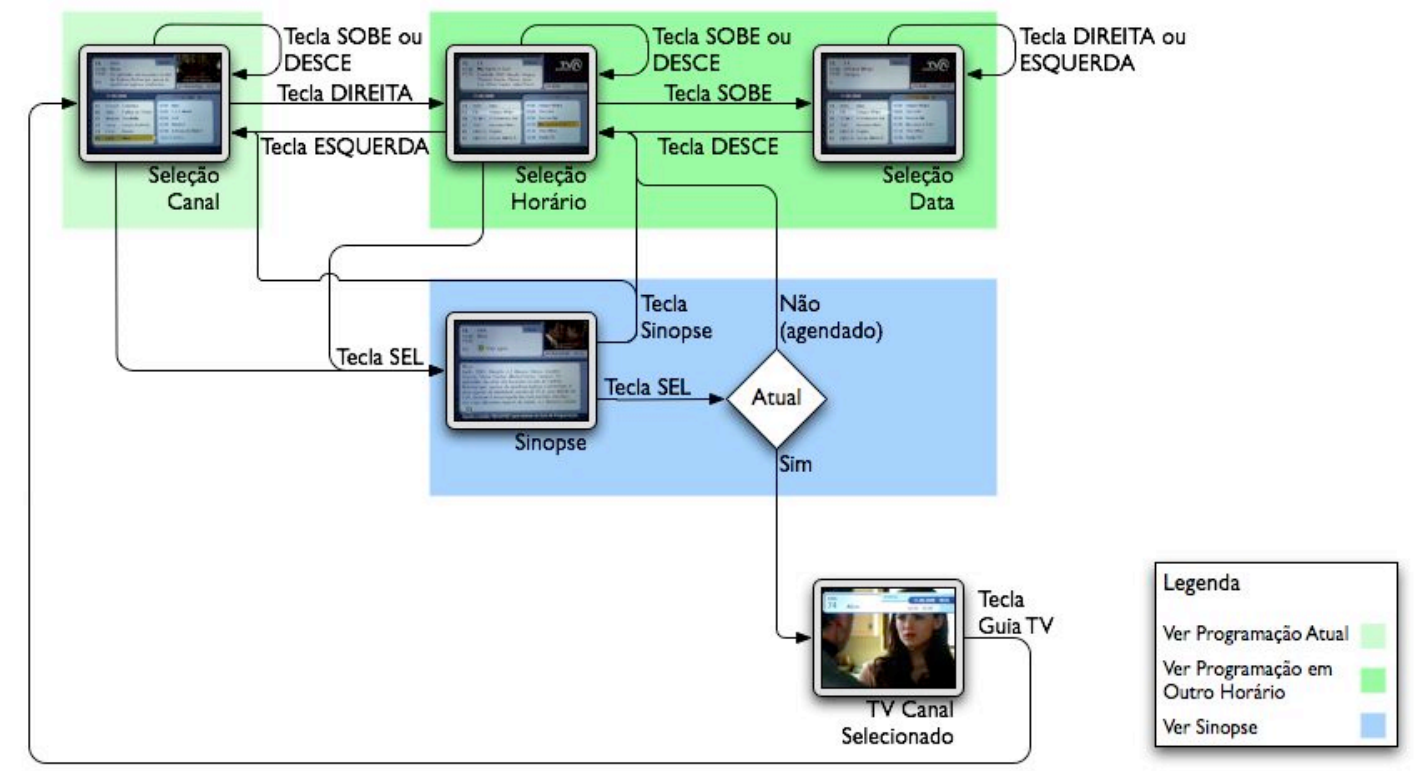

Figura 4-51 - Navegação do guia da plataforma TVA Digital

Esta plataforma tem seu guia de programação no formato de dois painéis (Figura 4-45). No painel da esquerda é feita a seleção do canal pelas setas verticais enquanto que no painel da direita estas setas são utilizadas para a seleção do programa por horário. Para selecionar outra data é necessário ir até o topo da lista dos programas, subir mais uma vez e então utilizar as setas horizontais para trocar de data. Para sair da seleção de data utiliza-se a seta para baixo.

Apertando a tecla de confirmação sobre um canal ou sobre um programa o usuário vai para a tela de sinopse (Figura 4-47). Caso o programa seleciona- 
do seja no horário atual esta tela dá a opção para ir para o programa, o que é feito pela tecla de confirmação. Caso seja um programa em um horário futuro a tela dá a opção para agendá-lo, o que também é feito pela tecla de confirmação.

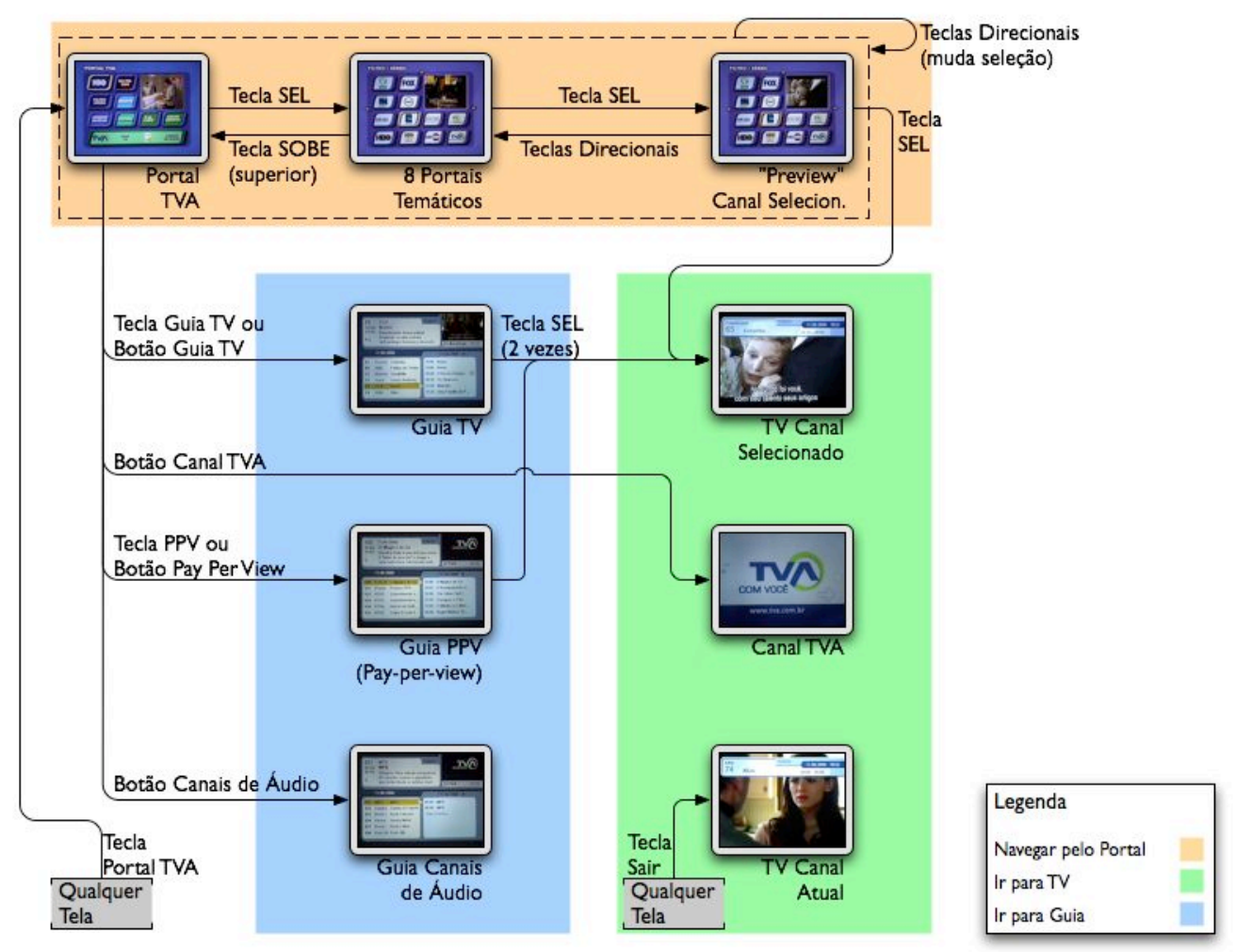

Figura 4-52 - Navegação do portal da plataforma TVA Digital

A navegação pelo portal principal e pelos portais temáticos é feita pelas setas direcionais e pela tecla de confirmação. No portal principal o usuário pode ir para os portais temáticos selecionando um dos botões presentes na interface e pressionando a tecla de confirmação (Figura 4-43).

Nos portais temáticos o usuário novamente utiliza as setas direcionais para selecionar um dos canais disponíveis. Ao pressionar a tecla de seleção o canal é sintonizado na janela de previezw no canto superior direito. Pressionando novamente a tecla de confirmação o usuário vai para aquele canal.

O guia de programação pode ser acessado tanto por um botão no portal principal quanto por uma tecla dedicada no controle remoto. Do guia o usuário pode facilmente ir para um canal da TV. 
No portal principal também há um botão que leva para a TV, mas sintoniza o canal informativo da plataforma. De qualquer tela também é possível pressionar a tecla Sair, que é um atalho para a tela de TV no canal atual.

\subsubsection{Plataforma NET Digital}

\section{Descrição da Plataforma}

A NET Digital também é uma plataforma de TV digital a cabo, com aproximadamente 60 canais.

Muito semelhante à plataforma anterior, a principal diferença está na presença de alguns aplicativos de TVi, como jogos e uma tabela para acompanhar os jogos da Copa do Mundo. 
Mapa de Navegação da Plataforma

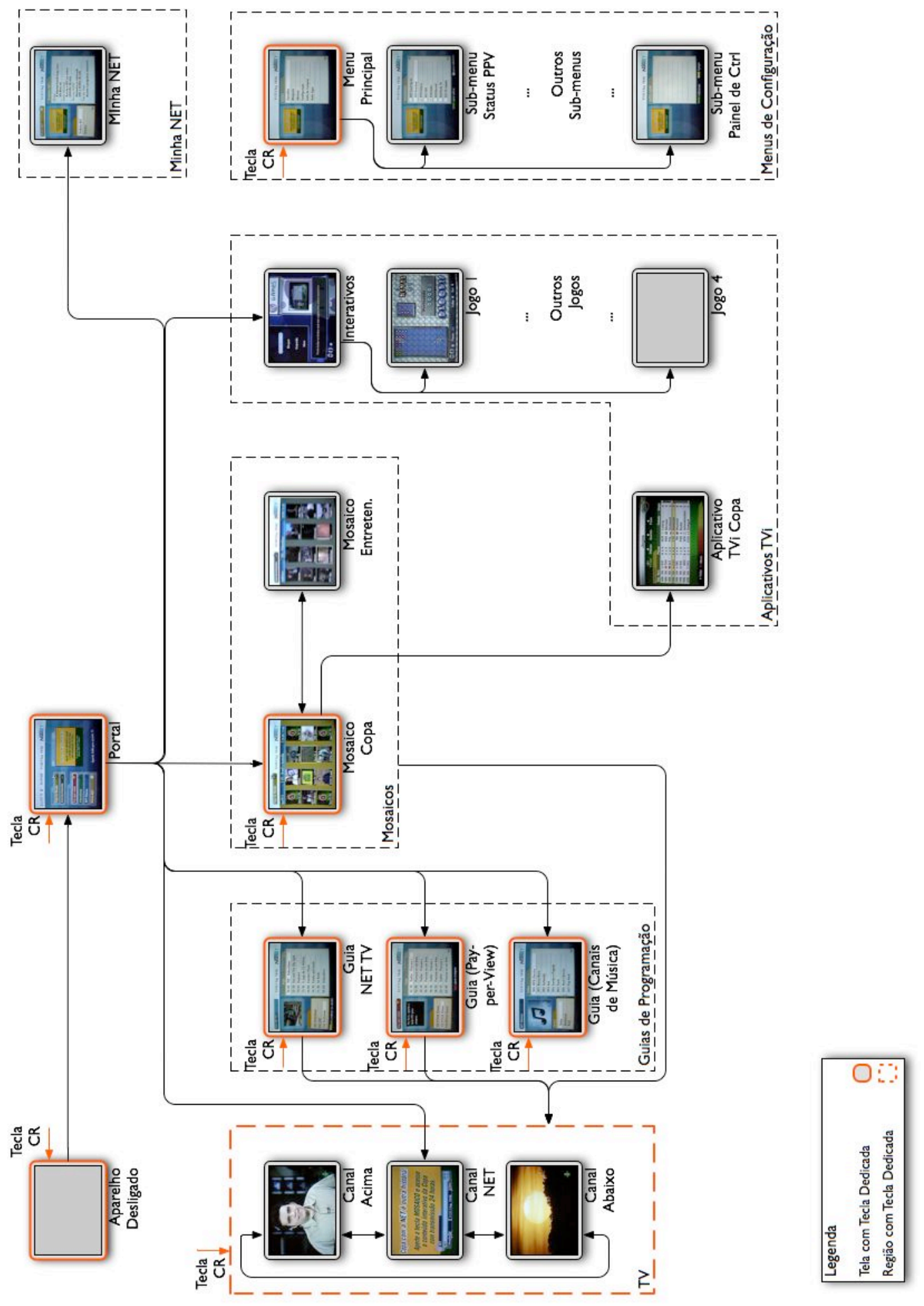

Figura 4-53 - Mapa de navegação da plataforma NET Digital 
A primeira tela que esta plataforma apresenta ao ser ligada é o portal (Figura 4-58) com o canal informativo da plataforma em tamanho reduzido e 8 botões para acesso a outras telas da interface, sendo que 5 destas telas têm teclas dedicadas no controle remoto (TV, os três guias de programação e um dos Mosaicos).

De forma análoga à plataforma anterior, os três guias desta plataforma são faixas diferentes do guia de programação. A única diferença é que os canais de áudio aqui são chamados de canais de música e estão na faixa de canais que começa no número 300, ao invés de 200.

Ao invés dos portais temáticos da plataforma anterior esta plataforma tem Mosaicos temáticos. Um mosaico mostra o vídeo em tamanho reduzido de até 12 canais simultaneamente. Apenas um destes 12 canais fica selecionado e o áudio é referente ao canal selecionado. Ao se trocar a seleção o áudio passa a ser o do novo canal selecionado.

O botão de Interativos dá acesso a 4 jogos simples (variações de jogos arcade). Quando o sistema foi analisado também havia um aplicativo para acompanhar os jogos da Copa do Mundo, mas o acesso a este aplicativo era feito exclusivamente através do mosaico da Copa do Mundo e não pelo menu de aplicativos interativos.

Mais uma vez o menu de configuração só é acessível por uma tecla dedicada no controle remoto. 


\section{Telas da Plataforma}

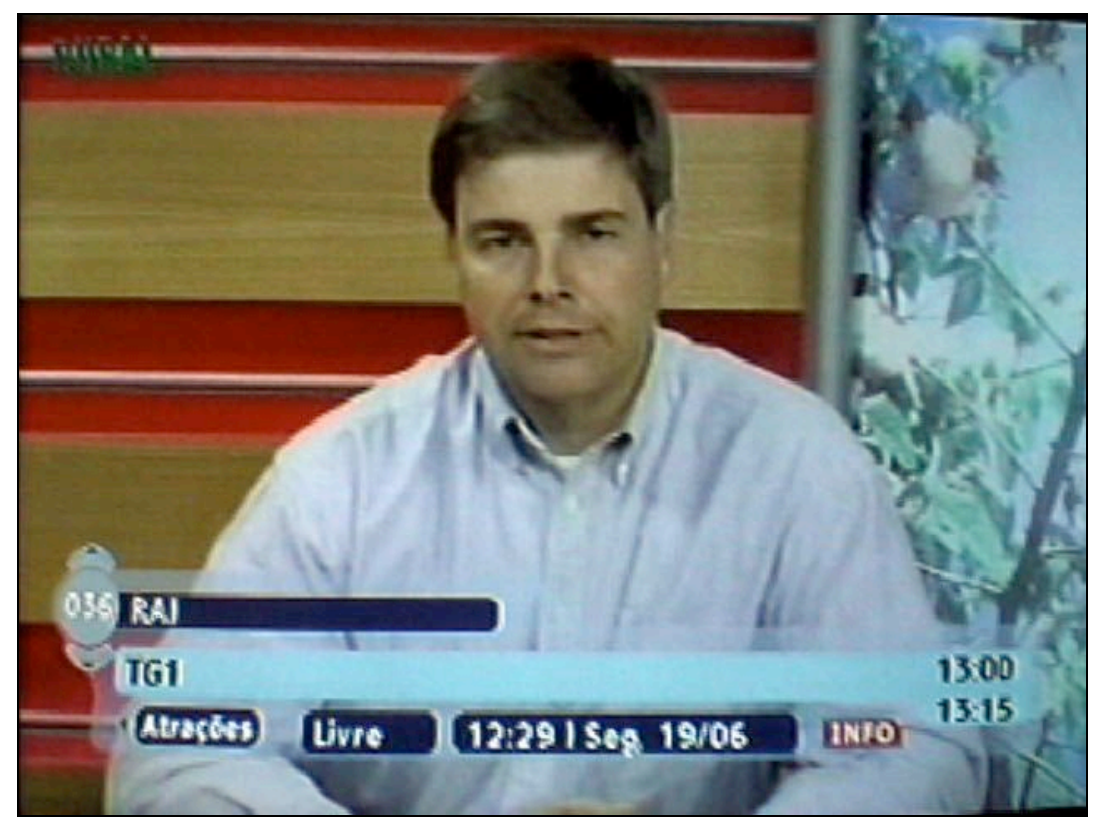

Figura 4-54 - Tarja de informações da plataforma NET Digital

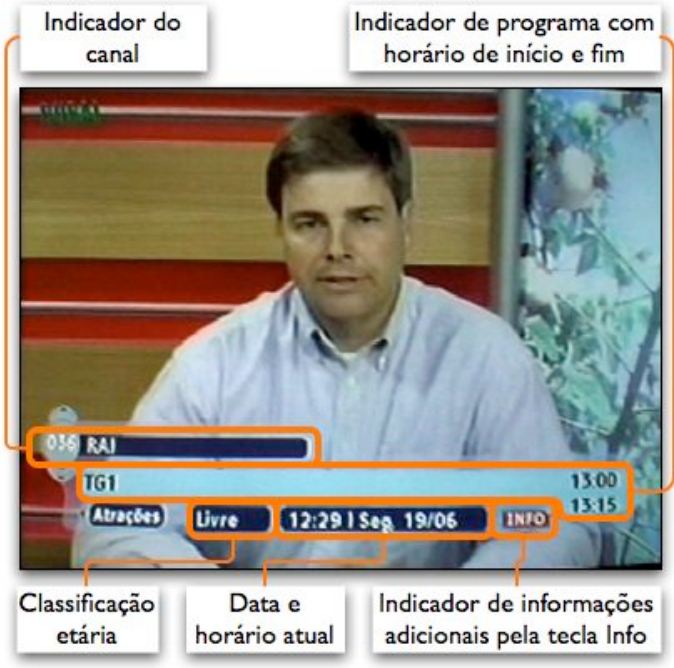

Figura 4-55 - Detalhes da tarja de informações da plataforma NET Digital
A tarja de informações desta plataforma (e das próximas duas) aparece na parte inferior da tela (Figura 4-54 e Figura 4-55). Apresenta as informações básicas de canal e programa, com horário de início e fim, assim como data e horário atual. Também apresenta a classificação etária do programa, assim como um indicador de funcionalidade da tecla Info. Ao pressionar esta tecla o sistema mostra uma tarja com a sinopse

do programa.

De forma análoga à plataforma anterior, esta também mostra na tarja a programação de outros canais (setas verticais) no horário atual e no próximo (setas horizontais). Apresenta uma latência semelhante para a troca de canal e mais uma vez a tarja pode ser utilizada para navegação entre canais. 
Ainda que discretos, esta plataforma apresenta indicadores das possibilidade de navegação entre canais e horários através das setas direcionais, que tem o mesmo formato das teclas direcionais do controle remoto. A tecla Info também está em vermelho para indicar que neste contexto a tecla Vermelha (das teclas coloridas) tem a mesma função da tecla Info.

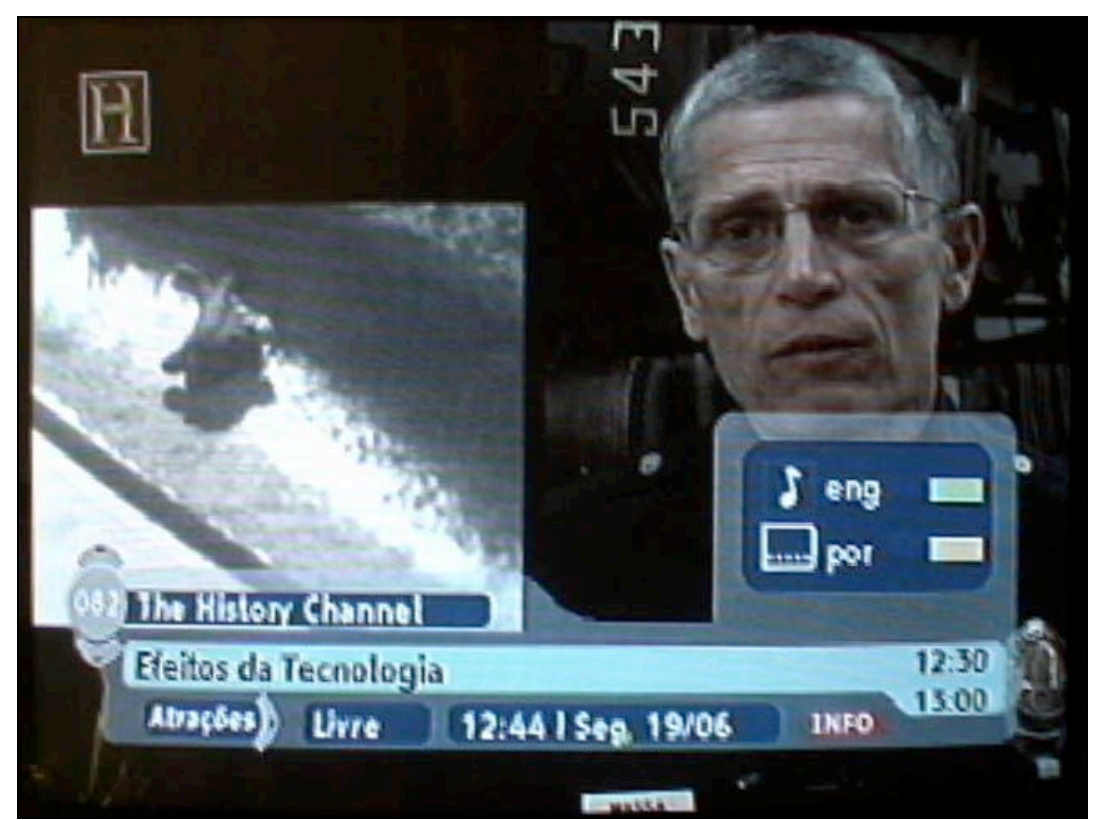

Figura 4-56 - Opções de legenda e áudio alternativo da plataforma NET Digital

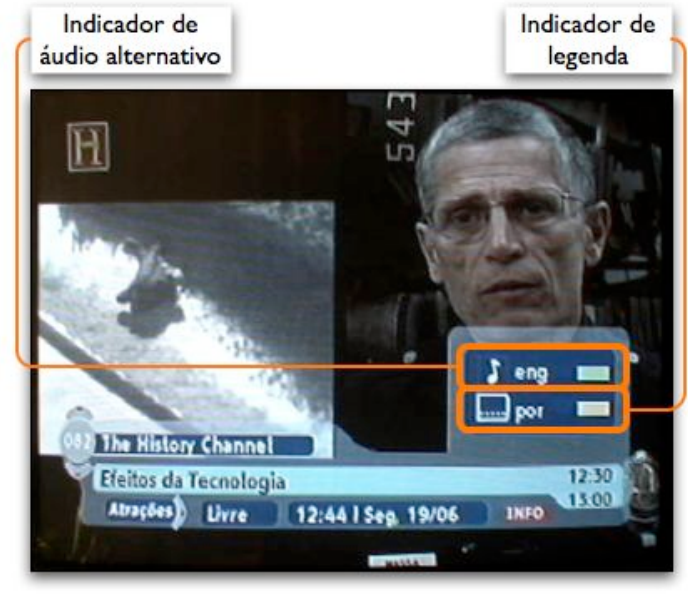

Figura 4-57 - Detalhes das opções de legenda e áudio alternativo da plataforma NET Digital
Ao pressionar a tecla Opções aparece a tela de opções de áudio e legenda alternativos (Figura 4-56 e Figura 4-57). Caso a tarja de informações já esteja visível ela permanece visível e somente as opções de áudio e legenda aparecem. Uma vez acionada, a troca de áudio e legenda é feita pelas teclas coloridas verde (áudio) e amarela (legenda). Quando não existe áudio ou legenda disponível o único indicador é que a tecla colorida correspondente não apare-

ce. 
Neste caso existe uma continuidade visual entre a tarja de informações e as opções de áudio e legenda. No entanto, as informações de áudio e legenda são referentes apenas ao canal sintonizado. Caso o usuário navegue através das informações da tarja por outros canais ou horários tem a impressão de que está vendo as opções de áudio e legenda do canal correspondente, mas isto não é o que acontece.

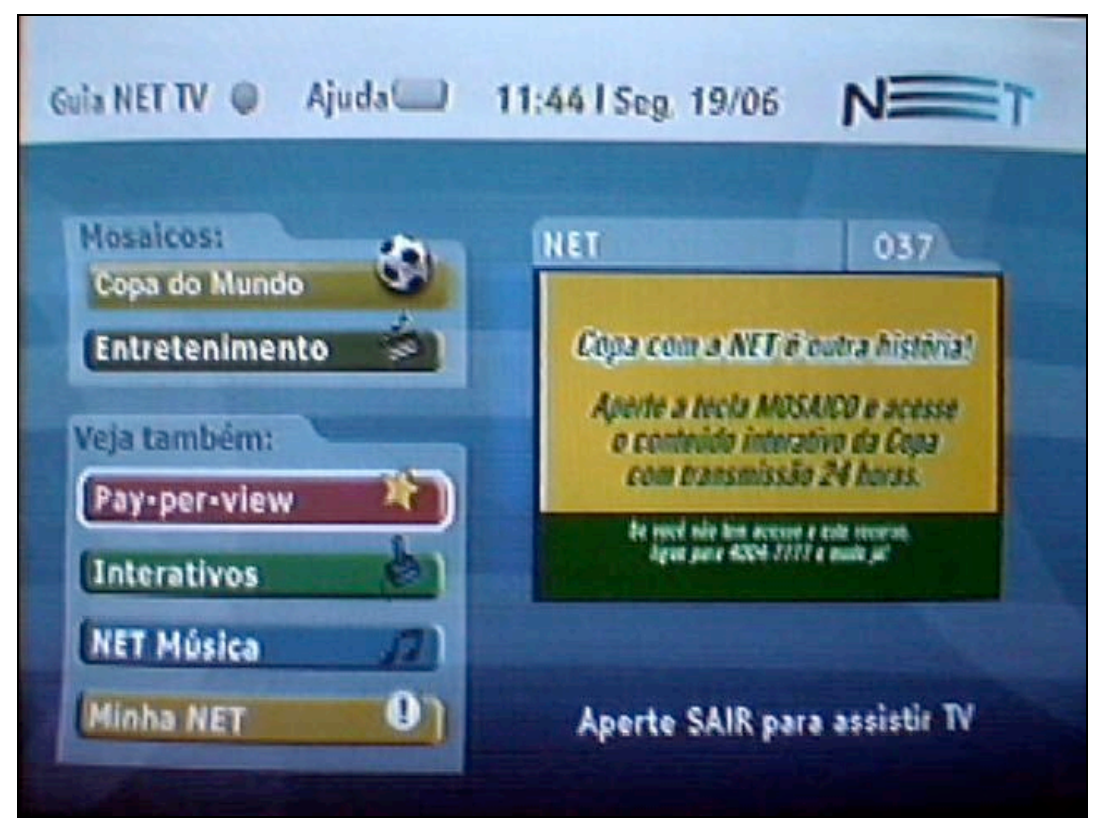

Figura 4-58 - Tela de portal da plataforma NET Digital

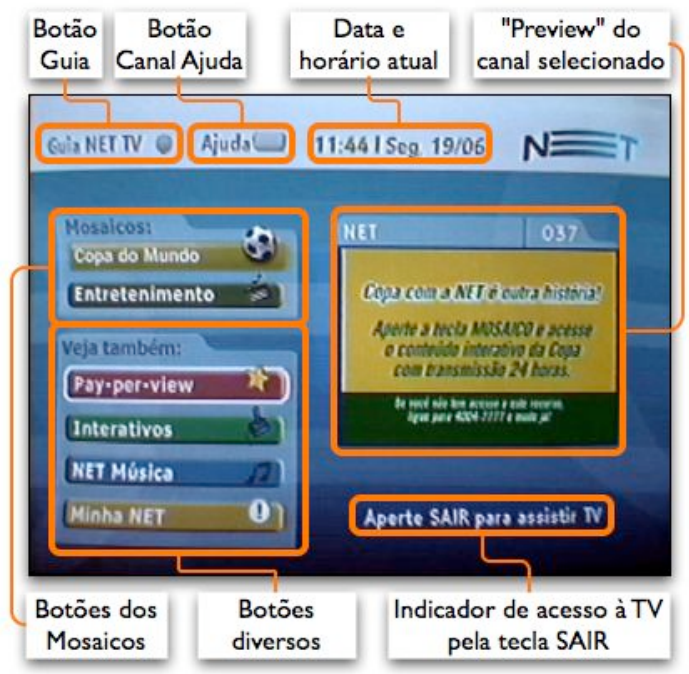

Figura 4-59 - Detalhes da tela de portal da plataforma NET Digital
A tela de portal (Figura 4-58 e Figura 4-59) é o ponto de partida para a navegação pelo sistema. Ela apresenta oito botões arranjados em três grupos.

Destes oito botões, dois têm aparência muito diferente (Guia NET TV e Ajuda) e não têm um indicativo visual de que são botões. Também são teclas dedicadas no controle remoto (assim como um dos mosaicos, Pay-per-view e NET Música). Para selecionar os diversos botões são 
utilizadas as teclas verticais, exceto para os botões de Guia NET TV e Ajuda, que para alternar entre um e o outro são utilizadas as teclas horizontais. Apesar de ter o nome de Ajuda o botão leva para um canal promocional da plataforma, e não para um sistema de ajuda.

Sempre que esta tela é carregada o vídeo vai para o canal informativo da plataforma, mas é possível trocar de canal nesta tela pelo teclado numérico.

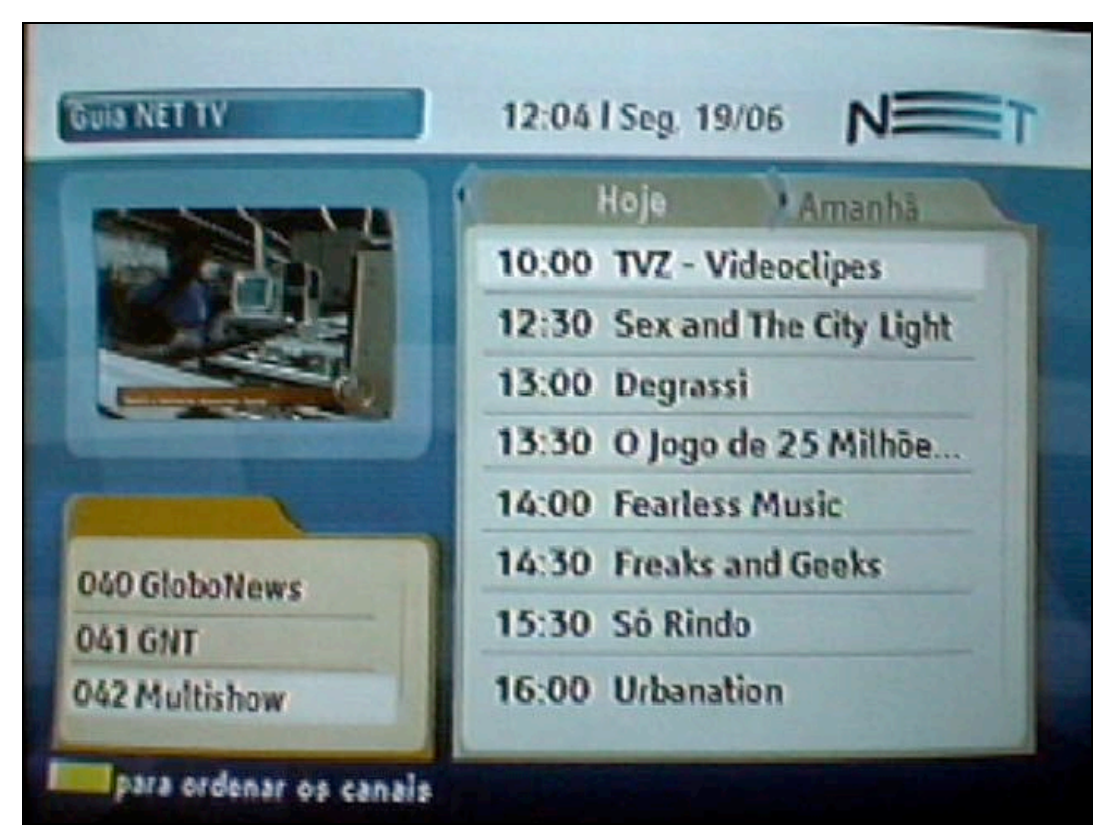

Figura 4-60 - Guia de programação da plataforma NET Digital

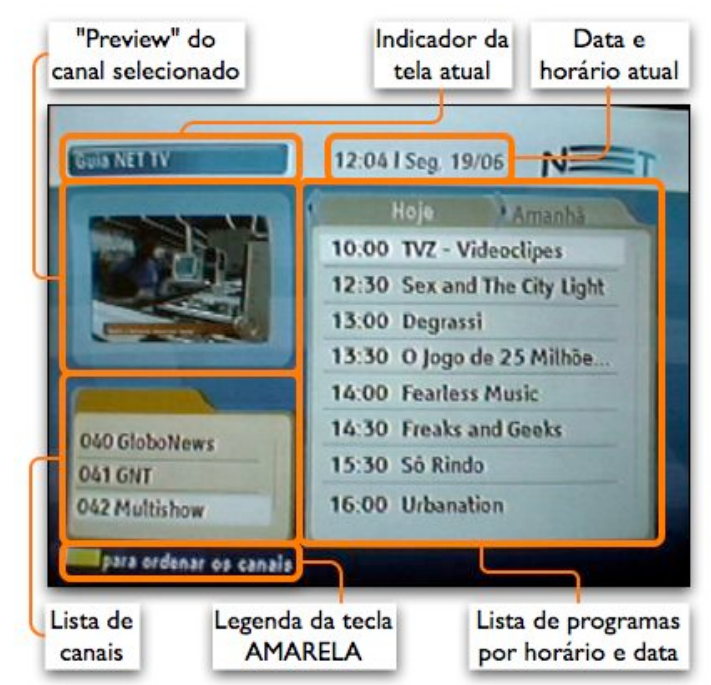

Figura 4-61 - Detalhes do guia de programação da plataforma NET Digital
O guia de programação da NET digital segue o paradigma da plataforma anterior, com dois painéis lado a lado, o da esquerda com uma lista de canais e o da direita com a lista de programas por horário para um canal específico (Figura 4-60 e Figura 4-61).

Este guia também tem uma imagem reduzida do canal sintonizado. Tem menos informa- 
ções sobre o programa selecionado, mas mostra mais programas por canal e utiliza um tamanho de fonte maior e mais espaçada.

Nesta interface a tecla amarela permite trocar a ordem dos canais. Além da ordem por numeração (todos) também permite uma ordenação por ordem alfabética (alfabética). Se o usuário pressionar novamente a tecla amarela são mostrados 10 sub-conjuntos dos canais agrupados por temas (filmes, esportes, étnicos, etc.). Os 10 sub-conjuntos de canais são organizados em ordem alfabética e portanto não seguem a ordem numérica dos canais, o que a princípio é estranho caso o usuário já esteja acostumado à seqüência numérica (que utiliza ao navegar pelos canais).

Da mesma forma que na plataforma anterior, a navegação entre canais e entre programas é feita pelas setas verticais e a passagem de um painel para o outro utiliza as setas horizontais. A navegação entre dias nesta plataforma é mais simples, pois basta continuar caminhando para a direita para ver os próximos dias (e para a esquerda para voltar até o dia de hoje). Ao mudar de um dia para o outro, porém, o horário não se mantém e passa para o primeiro horário do dia (normalmente entre 5:00 e 6:00 da manhã). 


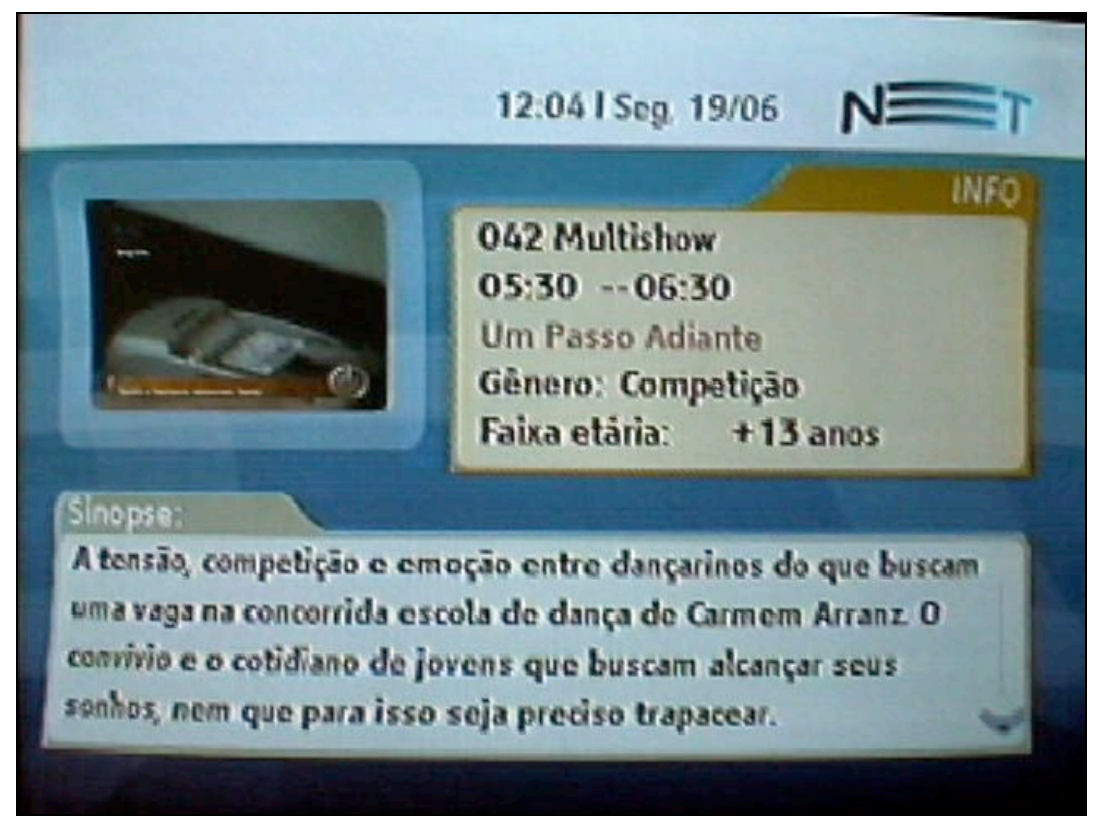

Figura 4-62 - Tela de sinopse da plataforma NET Digital

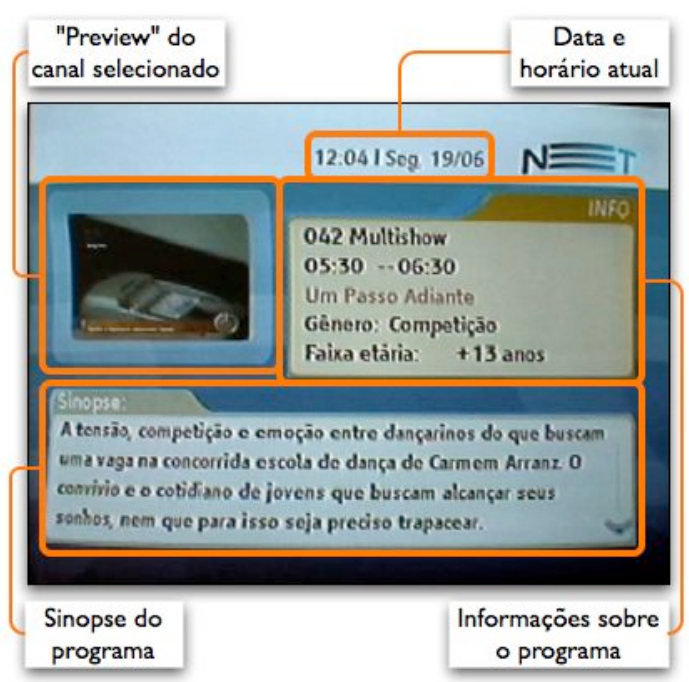

Figura 4-63 - Detalhes da tela de sinopse da plataforma NET Digital
Ao confirmar a seleção de um canal ou de um programa atual nesta plataforma o usuário vai diretamente para o canal correspondente. Caso seja um programa futuro, o usuário vai para tela de sinopse (Figura 4-62 e Figura 4-63).

Nesta tela as setas verticais são utilizadas para mudar a página da sinopse. Como esta plataforma tem uma tecla Voltar ela é utilizada para retornar à tela do guia de programação.

Nesta tela a tecla de confirmação leva sempre para o canal selecionado. Se a sinopse consultada for de um programa atual é este programa que é sintonizado, mas se for a sinopse de um programa futuro o que aparece na tela não corresponde ao conteúdo visto na sinopse. 


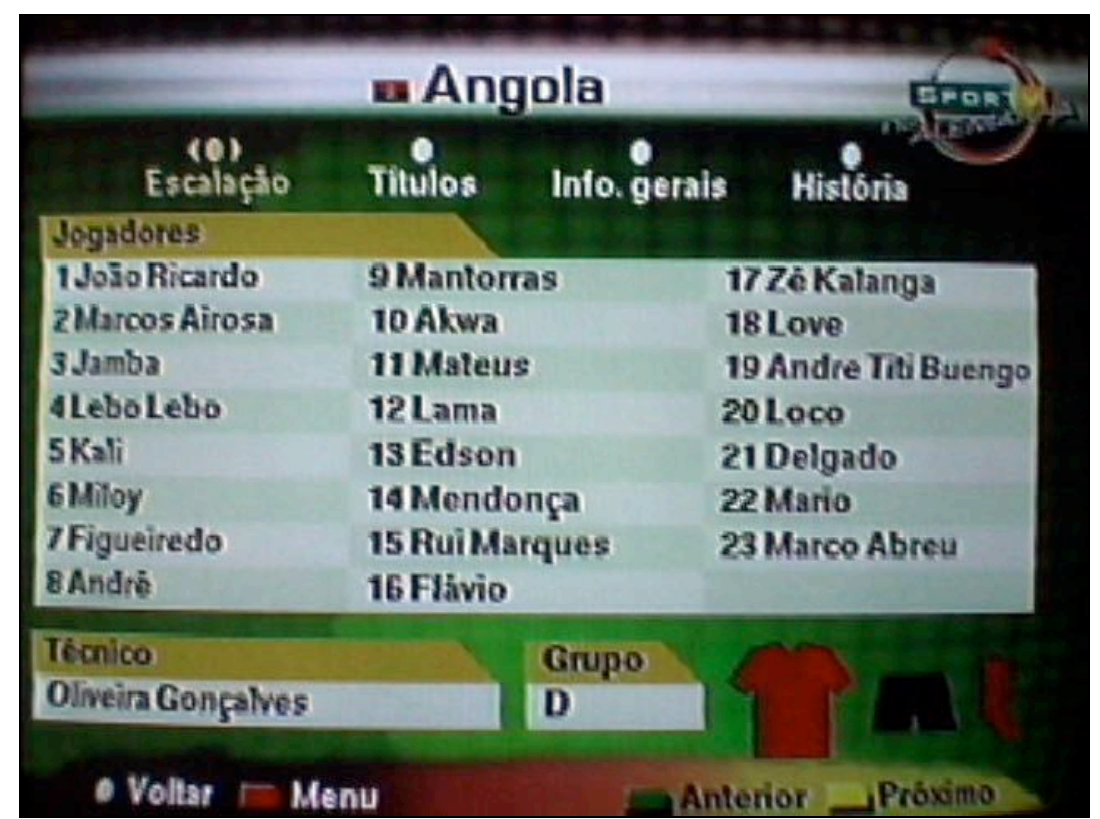

Figura 4-64 - Aplicativo com tabela de jogos de campeonato de futebol da plataforma NET Digital

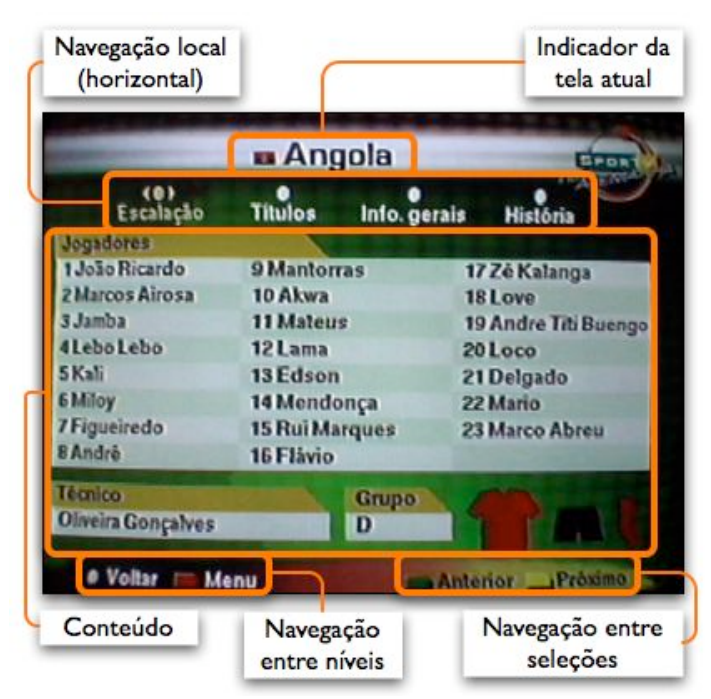

Figura 4-65 - Detalhes do aplicativo com tabela de jogos de campeonato de futebol da plataforma NET Digital
Este aplicativo da NET Digital mostra a tabela de jogos da Copa do Mundo. Nesta tela (Figura 4-64 e Figura 4-65), estão informações adicionais sobre os times que participaram do campeonato. Abaixo do título da página (Angola) está a navegação para ter acesso às diversas informações deste time (escalação, títulos, informações gerais e história), que é feita através das setas horizontais.

A navegação entre times é feita através das teclas coloridas verde e amarelo (canto direito inferior). As setas verticais não são utilizadas para isto porque em algumas telas (histórico, por exemplo) elas são utilizadas para a rolagem de texto.

Este aplicativo utiliza a tecla Voltar do controle remoto para voltar à tela anterior. A função de voltar respeita o histórico de navegação, ou seja, volta 
para a última tela onde se esteve e não simplesmente para o nível hierárquico superior. Por exemplo, se para chegar nesta tela o usuário passou pela tela de outro time, a tecla Volta retorna para aquele time, caso tenha vindo da listagem de times, volta para a listagem de times. A tecla vermelha é utilizada como um atalho para a tela inicial do aplicativo, que neste caso é chamada de Menu.

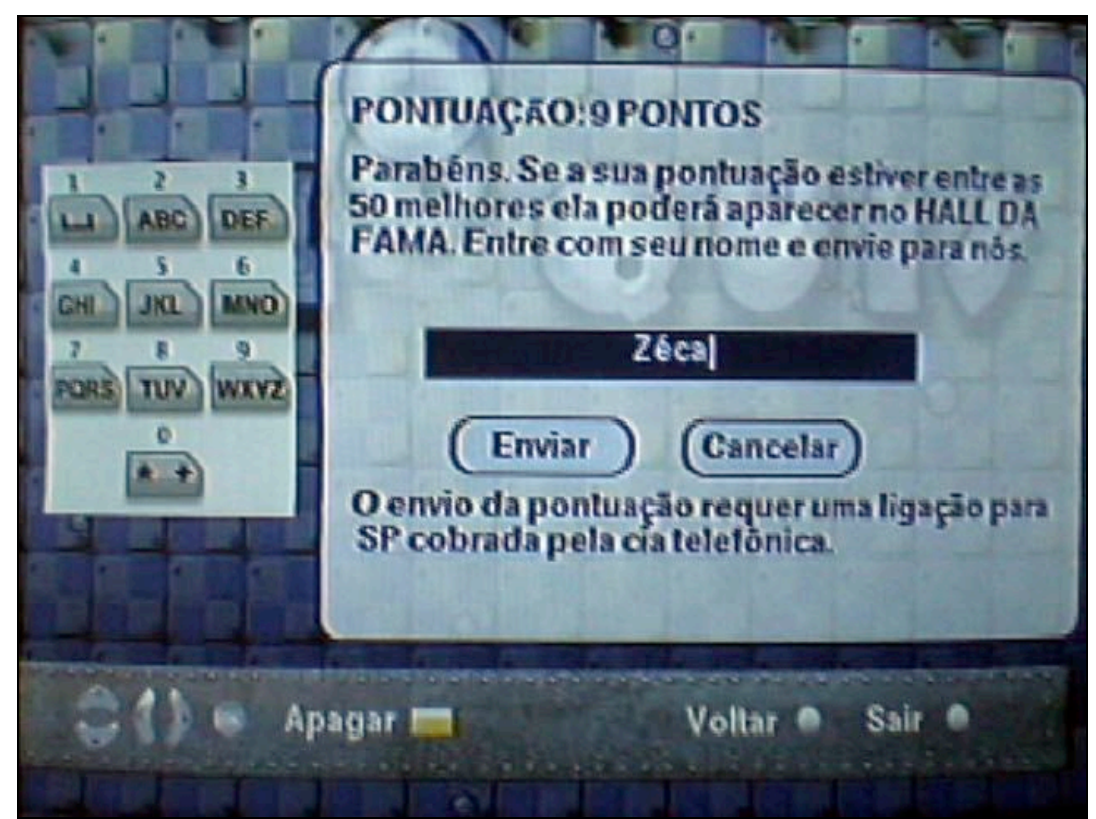

Figura 4-66 - Interface para entrada de texto em aplicativo da plataforma NET Digital

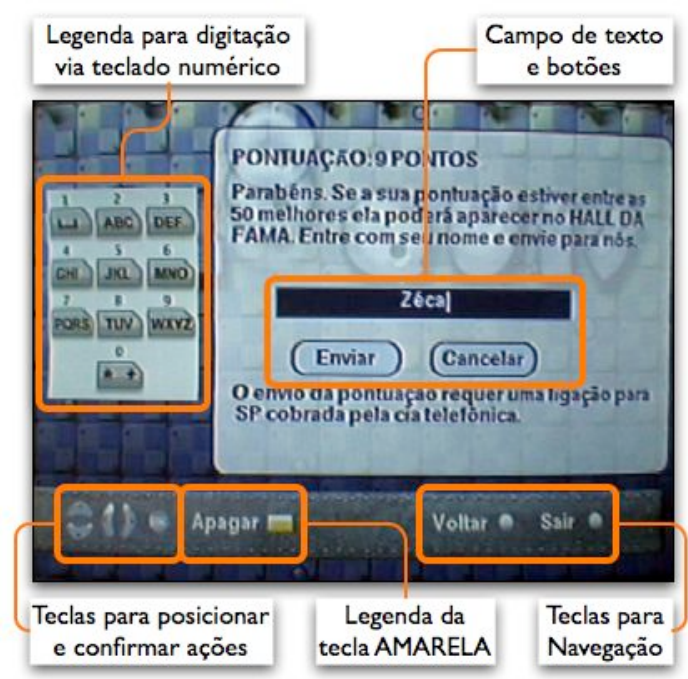

Figura 4-67 - Detalhes da interface para entrada de texto em aplicativo da plataforma NET Digital
Este aplicativo da NET Digital é uma variante do jogo Tetris. O jogo tem um placar com as melhores pontuações e ao final do jogo o usuário tem a opção de digitar seu nome e enviar sua pontuação. Esta é a tela que permite o usuário digitar seu nome através do teclado numérico do controle remoto (Figura 4-66 e Figura 4-67). Em grande parte ela segue a associação entre letras e dígitos que é encontrada em telefones 
celulares, que utilizam a norma ITU-T E.161.

Como esta associação entre letras e dígitos não está no controle remoto é necessário apresentá-la na tela. No entanto, os detalhes da entrada de texto, como posicionamento do cursor, letras maiúsculas e acentuadas são diferentes do padrão encontrado em telefones celulares. A tecla amarela é utilizada para apagar um caractere. Para enviar o texto escrito é necessário descer até o botão Enviar e pressionar a tecla de confirmação. A tecla Voltar leva de volta para a tela anterior e a tecla Sair fecha o jogo e leva o usuário de volta para a lista de jogos disponíveis. Durante o jogo, a tecla azul é utilizada para dar uma pausa (suspender temporariamente) o jogo. 


\section{Dispositivos da Plataforma}

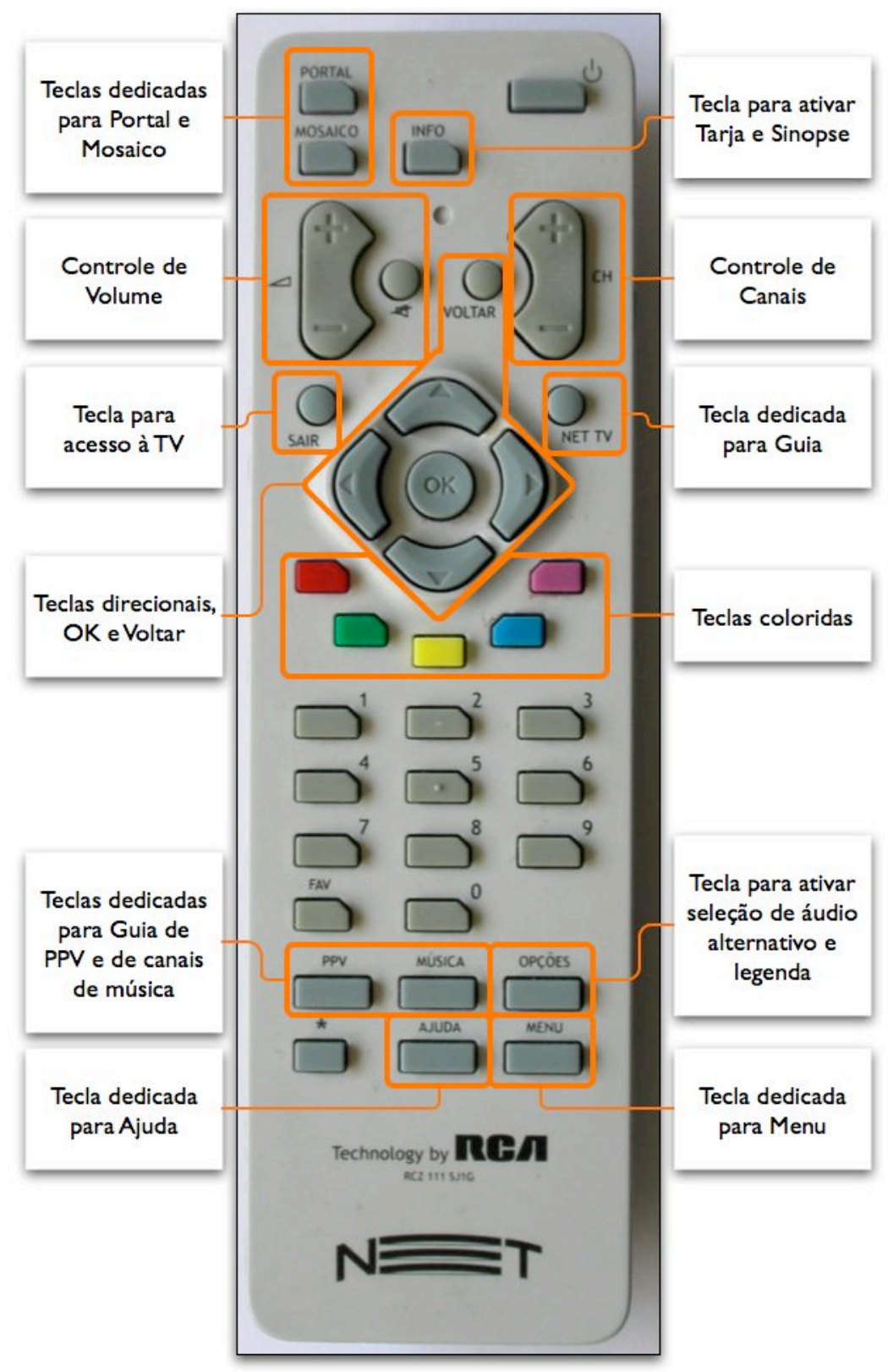

Figura 4-68 - Controle remoto da plataforma NET Digital

O controle remoto da NET Digital (Figura 4-68) agrupa os controles de canal, volume e mudo na parte superior do controle. A tecla Voltar fica ao lado das teclas de controle de canais e está longe das setas direcionais.

A tecla para acionar a tarja de informações (Info) também fica distante das setas direcionais, o que dificulta seu acesso. Nesta plataforma, porém, esta função também pode ser feita pela tecla de confirmação. 
Acima das setas direcionais à esquerda está a tecla para acesso à TV (Sair) e acima à direita a tecla para acesso ao guia (NET TV). Este controle tem cinco teclas coloridas ao invés de quatro (tem a tecla roxa na extremidade direita).

Para acionar as opções de áudio e legenda alternativos é necessário utilizar a tecla Opções, abaixo do teclado numérico à direita, bastante longe das teclas coloridas. Abaixo dela está a tecla Menu, única forma para acessar o menu de configurações.

A tecla Ajuda também fica neste conjunto de teclas, junto a duas teclas dedicadas de atalho para canais de áudio (Música) e canais Pay-per-view (PPV).

No total o controle tem 39 teclas e as legendas são em português.

\section{Navegação da Plataforma}

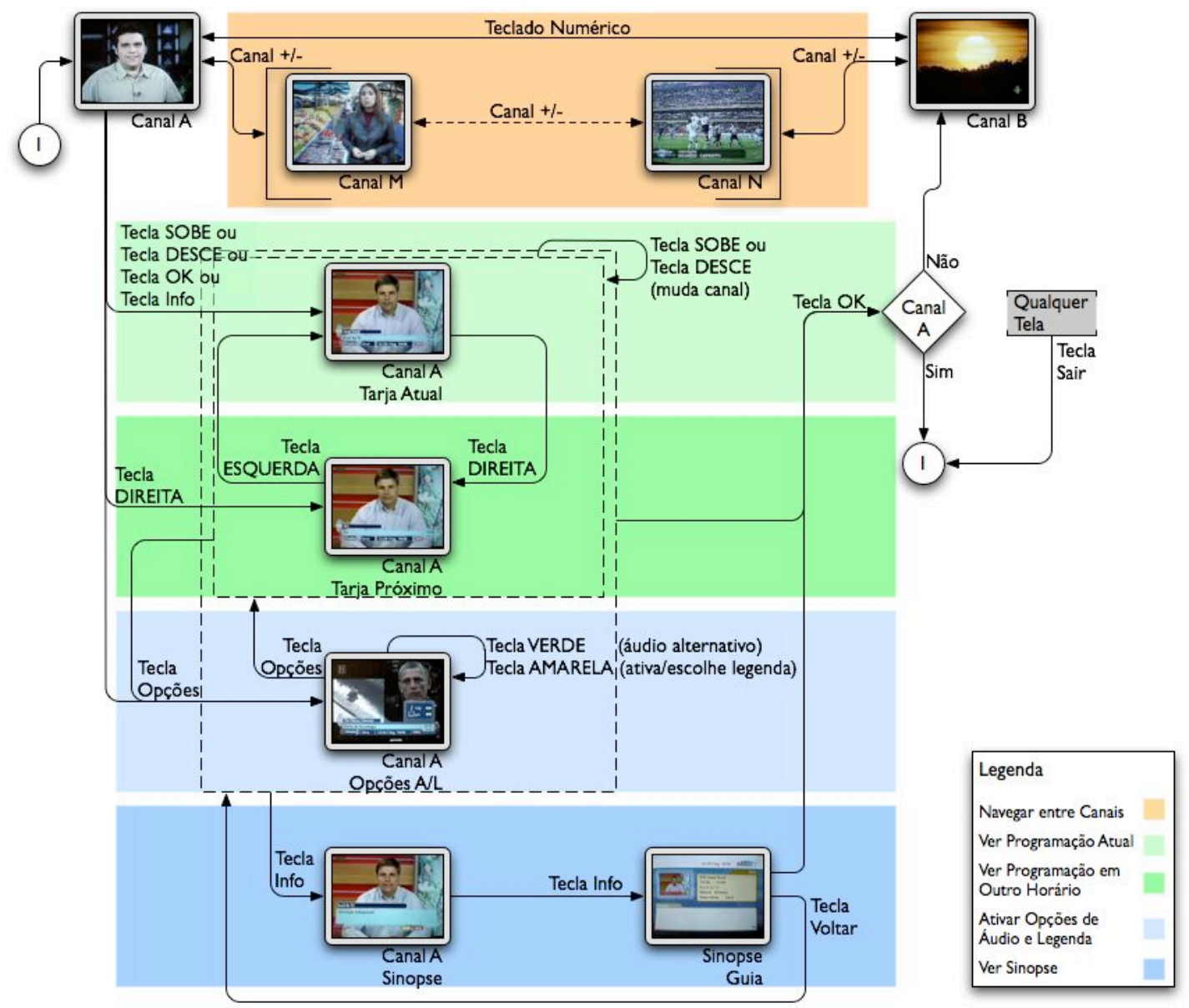

Figura 4-69 - Navegação de TV da plataforma NET Digital 
A funcionalidade da tarja de informações nesta plataforma é muito semelhante à vista na plataforma anterior. Porém o seu funcionamento apresenta algumas diferenças.

Por exemplo, ao se ativar a tarja pela tecla info ela mostra as informações do canal atual mas utilizando as setas verticais ela já mostra as informações dos canais adjacentes. A seta para a direita tem o mesmo funcionamento da plataforma anterior, e mostra o horário seguinte. Nesta plataforma a tecla de confirmação também abre a tarja de informações, ao invés das opções de áudio e legenda.

A tela de opções de áudio e legenda (Figura 4-56) é uma variante da tarja de informações (Figura 4-54). Se somente a tarja é ativada, ela aparece sem as opções, mas se for utilizada a tecla Opções a tarja aparece com as opções. Esta tecla também ativa ou desativa as opções de áudio e legenda se a tarja de informações já estiver aberta. $\mathrm{O}$ funcionamento da tarja continua o mesmo, mas as opções de áudio e legenda são relativas apenas ao canal sintonizado, e não ao canal cujas informações estão sendo mostradas na tarja de informações.

Ao pressionar a tecla Info na tarja de informações (com ou sem opções de áudio e legenda) o usuário vai para uma tela de sinopse sobre o vídeo. Pressionando novamente esta tecla o usuário vai para a tela de sinopse do guia de programação e a tela de TV fica reduzida no canto superior esquerdo. Da sinopse do guia o usuário pode pressionar a tecla Voltar para voltar para o canal.

Nesta plataforma a tecla de voltar tem funcionamento distinto na tela de TV ou em outras telas do sistema. No contexto de TV a tecla Voltar funciona como a tecla Last Ch. da TV aberta, que serve para alternar entre os dois últimos canais sintonizados (vai do canal A para canal B e vice-versa). Nos outros contextos (portal, guia de programação, aplicativos TVi) a tecla Voltar funciona com um histórico de telas (volta passo a passo), como o inverso da tecla de confirmação.

Por este motivo a tecla de volta não é utilizada na navegação da tarja (pois trocaria de canal sintonizado), mas é utilizada na tela de sinopse que pertence ao guia de programação. De forma idêntica à plataforma anterior, 
em qualquer situação a tecla Sair pode ser utilizada como um atalho para a tela da TV.

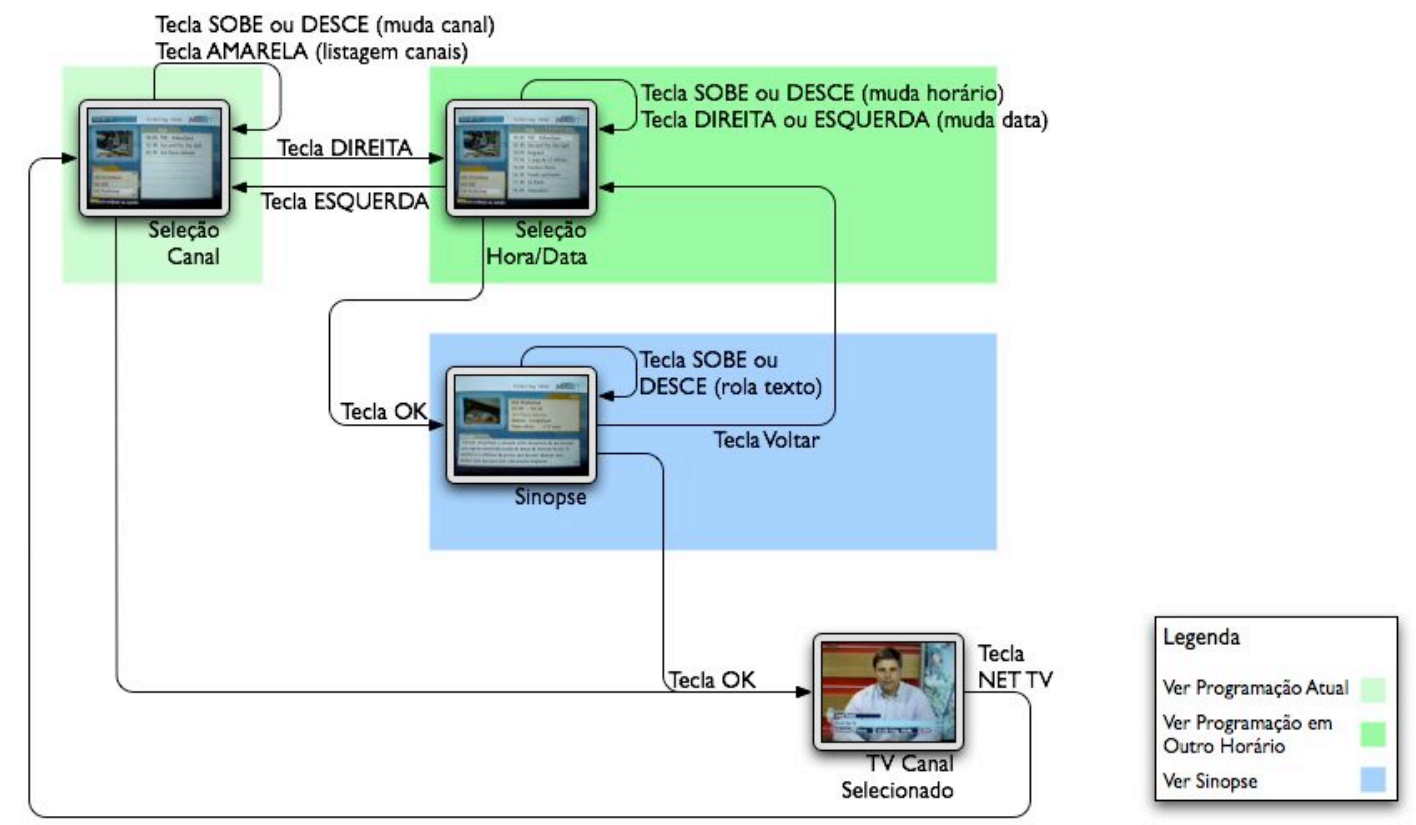

Figura 4-70 - Navegação do guia da plataforma NET Digital

O guia de programação desta plataforma também é semelhante ao da plataforma anterior, mas apresenta algumas particularidades. Ambos utilizam o paradigma de dois painéis sendo o da esquerda uma lista de canais e o da direita a lista de programas (Figura 4-60). Para selecionar os diferentes canais e programas são utilizadas as setas verticais e para alternar entre os dois painéis são utilizadas as setas horizontais. Nesta plataforma, porém, a lista de canais pode ser modificada através da tecla amarela, com 12 opções possíveis.

No painel de horários, além da seleção dos programas (pelas setas verticais) é possível ver outras datas da programação (através das setas horizontais).

Nesta plataforma o usuário vai diretamente para a TV ao selecionar um programa no horário atual. Caso selecione um programa em um horário futuro ele é direcionado para a tela de sinopse (Figura 4-62). Desta tela o usuário pode voltar para o guia de programação, se confirmar a seleção (de um programa futuro) vai para o canal daquele programa, apesar do programa que está sendo apresentado não corresponder à sinopse vista. 


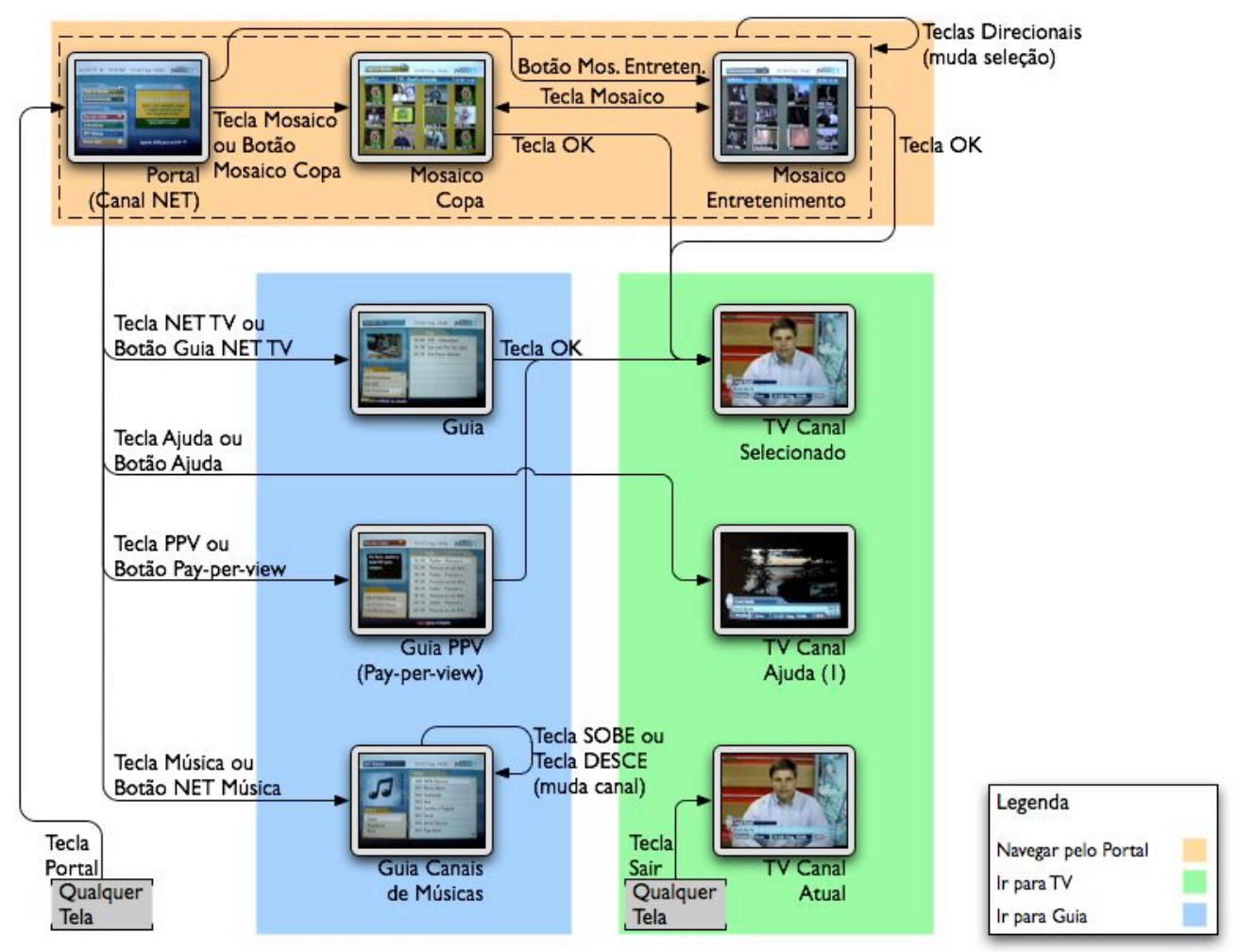

Figura 4-71 - Navegação do portal da plataforma NET Digital

A navegação pelo portal principal (Figura 4-58) e pelas telas de mosaico é feita pelas setas direcionais e pela tecla de confirmação. O mosaico também pode ser acessado por uma tecla dedicada no controle remoto e caso o usuário já esteja em um dos mosaicos esta tecla alterna entre os dois mosaicos.

Das telas de mosaicos o usuário pode acessar diretamente um dos canais (máximo de 12 por mosaico) pela tecla de confirmação.

Para ir do portal para o guia o usuário pode utilizar tanto a uma tecla dedicada no controle remoto (cuja legenda é NET TV) ou pode utilizar um botão na interface gráfica (chamado Guia NET TV). Também pode ir para o guia de Pay-per-view, que também tem um botão na interface gráfica e uma tecla dedicada no controle remoto. De qualquer um dos guias o usuário pode ir para a TV.

Outra forma de ir do portal para a TV é através da ajuda, que também tem uma tecla dedicada no controle remoto e um botão na interface gráfica. No entanto, o usuário não vai para uma tela de ajuda, e sim para um canal promocional da plataforma, o que é uma aplicação ruim do termo ajuda. 
A tecla Sair também pode ser utilizada para ir para a TV, mas nesta plataforma ao ir para o portal o canal da emissora sempre é sintonizado, o que obriga o usuário a mudar de canal mesmo quando utiliza a tecla Sair.

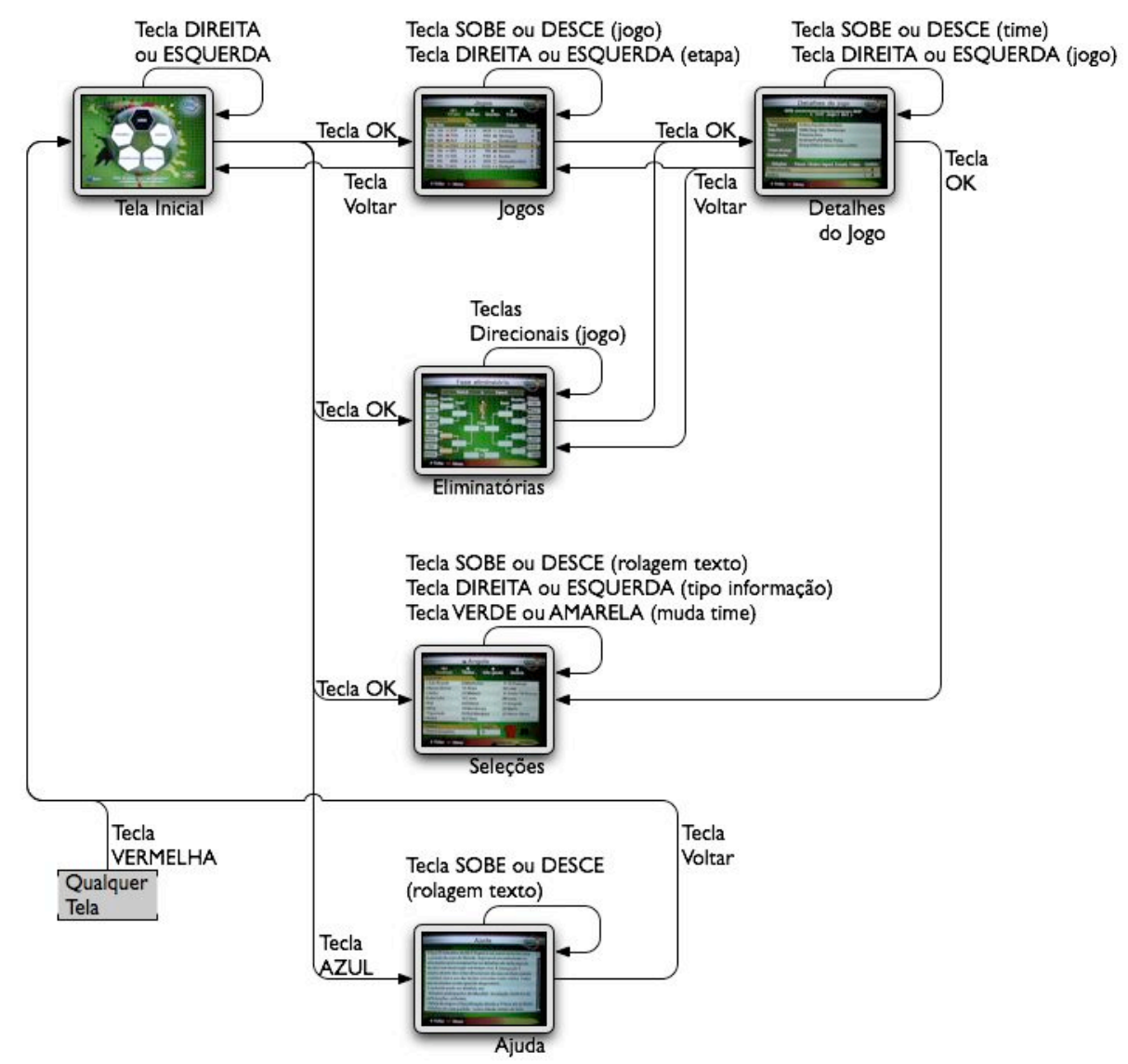

Figura 4-72 - Navegação do aplicativo com tabela de jogos de campeonato de futebol da plataforma NET Digital

A tela inicial deste aplicativo apresenta cinco opções de conteúdo (aqui estão exemplificadas três) mais uma tela de ajuda. Pelas setas horizontais se escolhe o conteúdo e a seta de confirmação leva para a tela correspondente. A tela de ajuda é acessada pela tecla azul do controle remoto e não pela tecla Ajuda do controle remoto.

A tela de jogos mostra uma lista dos jogos do campeonato. Pelas setas horizontais o usuário seleciona as diversas etapas do campeonato e pelas setas verticais seleciona os jogos de cada etapa. Pressionando a tecla de confirmação o usuário vai para a tela de detalhes do jogo selecionado. Nesta tela a navegação horizontal troca entre os diversos jogos (próximo ou anterior) e as teclas verticais selecionam um dos dois times do jogo. 
A tela de eliminatórias mostra os jogos desta outra etapa do campeonato em outra organização. Os jogos estão arranjados em duas árvores hierárquicas que convergem para o jogo final do campeonato. Para selecionar um jogo ou outro o usuário utiliza as setas direcionais e a tecla de confirmação leva novamente para a tela de detalhes do jogo. Caso o usuário utilize a tecla de voltar ele voltará para a tela de onde veio, ou seja, se foi para os detalhes do jogo a partir da lista de jogos voltará para a lista de jogos, se foi pela tela de eliminatórias, volta para a tela de eliminatórias.

A tela de seleções (Figura 4-64) é similar à de jogos com as setas horizontais servindo como uma navegação local (informações distintas sobre os times). No entanto, as setas verticais são utilizadas para rolagem de texto (na tela de histórico). Para a navegação entre times são utilizadas as teclas coloridas, em um paradigma diferente do utilizado no resto do aplicativo.

\subsubsection{Plataforma SKY}

\section{Descrição da Plataforma}

A SKY é uma plataforma de TV digital via satélite, que tem aproximadamente 40 canais. É a plataforma que mais utiliza os recursos de interatividade da TV digital com vários aplicativos de TVi e TVe. 
Mapa de Navegação da Plataforma

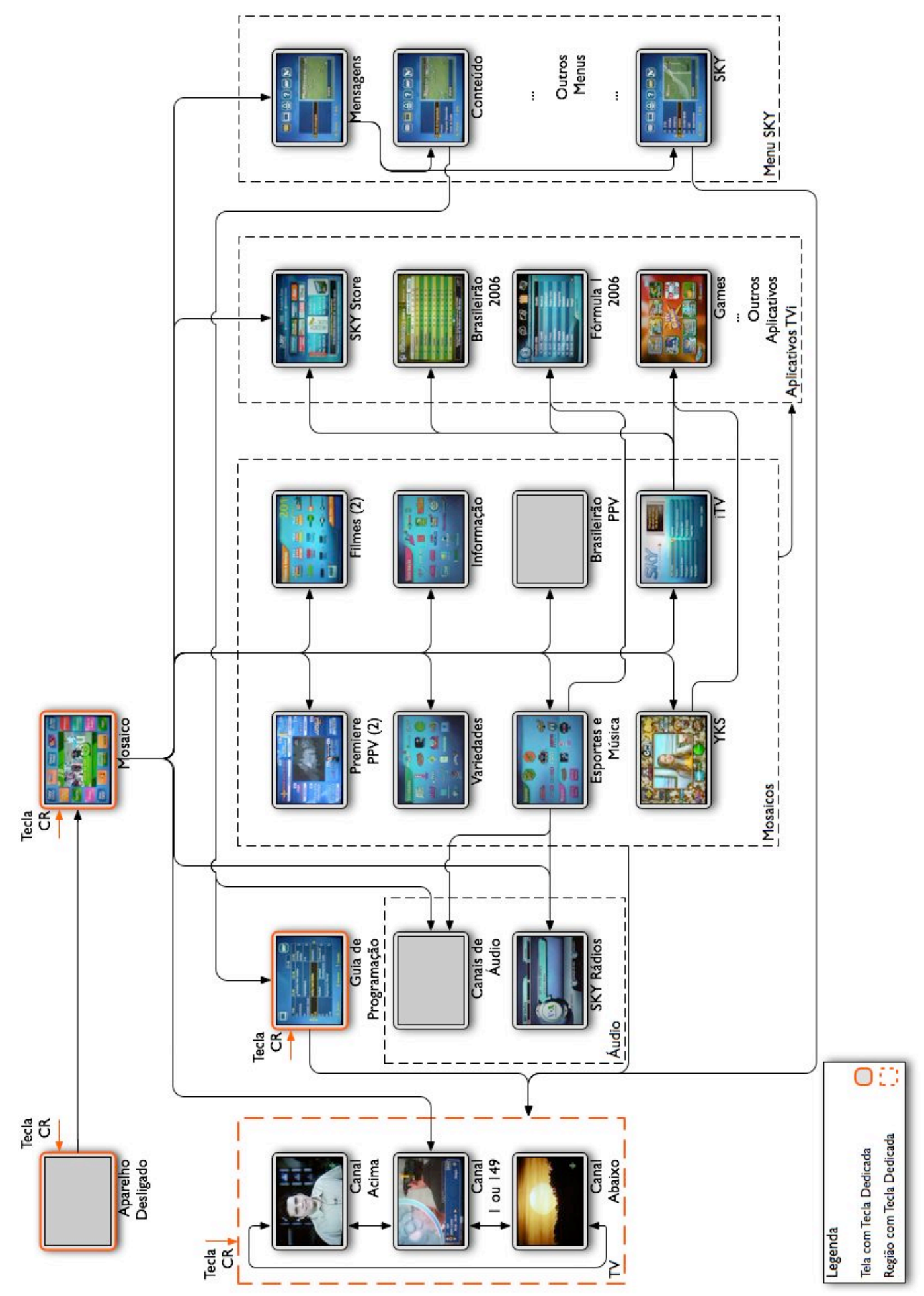

Figura 4-73 - Mapa de navegação da plataforma SKY 
Por ser a plataforma que mais utiliza os recursos de interatividade também é a plataforma com maior número de telas e navegação mais complexa. Além dos canais e do guia de programação esta plataforma tem vários aplicativos.

Sua estrutura de navegação é confusa e isto dificulta o uso dos recursos disponíveis. O guia de programação não é acessível diretamente a partir da tela inicial (é preciso passar pelo Menu SKY antes) e as telas de navegação têm muitos links entre si, formando uma estrutura de navegação interna complicada demais. Além disso, o tempo de carregamento de alguns aplicativos é grande e sistema não responde até o aplicativo estar carregado. Desta forma, clicar no ícone errado pode significar passar alguns segundos aguardando sem poder agir, o que desmotiva a exploração.

Nesta plataforma o termo Mosaico tem outro significado. Um mosaico da plataforma SKY é uma tela de navegação por ícones, que pode ter um canal de vídeo reduzido no meio da tela ou não (Figura 4-78 e Figura 4-80). Ao ser ligada vai para a tela de mosaico inicial, que sempre está sintonizada em o canal informativo da plataforma. Este mosaico inicial também é o canal 200.

É a única plataforma que tem aplicativos de TVe permanentemente em alguns canais (Figura 4-88). Para ativar estes aplicativos deve-se primeiro ir para o canal desejado para depois ativar o aplicativo.

Tem apenas um guia de programação e os canais de áudio têm uma interface própria. Um detalhe desta plataforma é que existem canais de áudio e rádios, que apesar de serem semelhantes em termos de uso (áudio sem vídeo associado) são conteúdos distintos e têm interfaces e formas de acesso independentes. Além do mosaico inicial existem outros 10 mosaicos temáticos sendo que dois temas (Pay-per-view e Filmes) tem duas telas de mosaico enquanto uma das telas tem dois mosaicos (Esportes e Música, Figura 4-80).

Esta plataforma tem aproximadamente 20 aplicativos: uma loja virtual (integrada ao site de compras submarino.com.br), informações sobre o campeonato de fórmula 1, uma tabela de jogos de campeonatos de futebol (Figura 4-86 e Figura 4-104), alguns jogos simples e horóscopo, entre outros. 


\section{Telas da Plataforma}

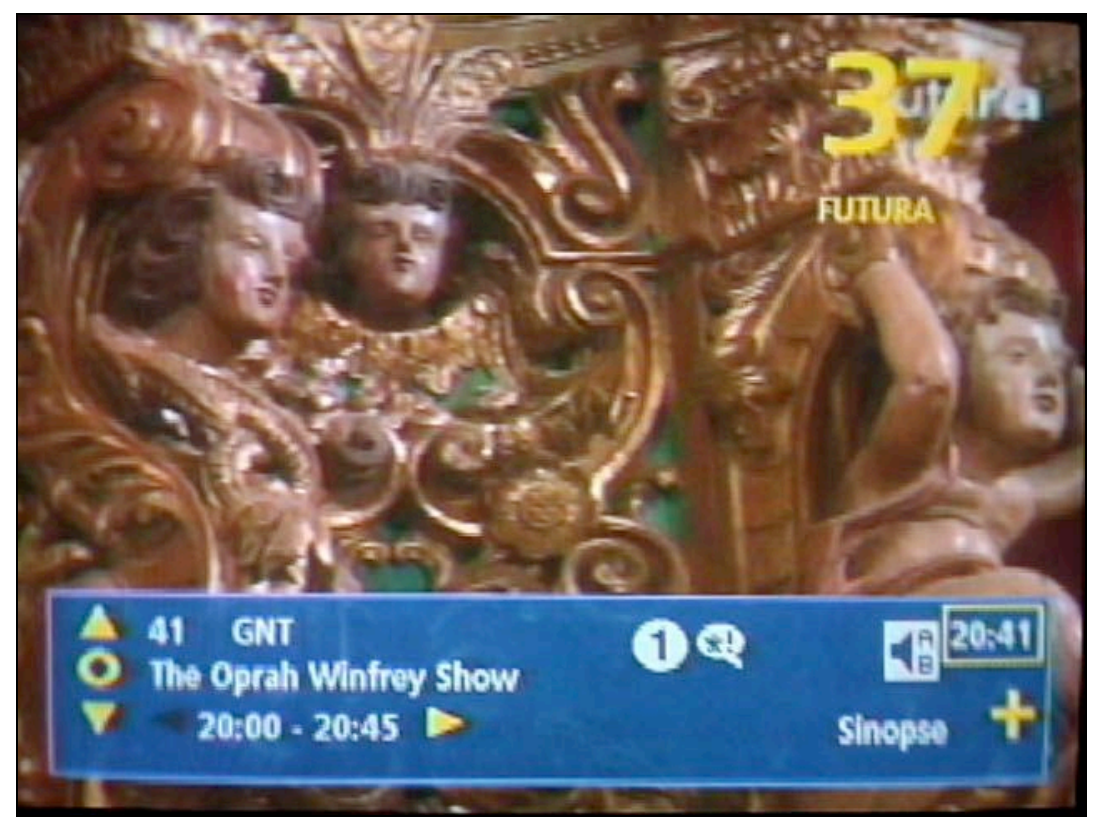

Figura 4-74 - Tarja de informações da plataforma SKY

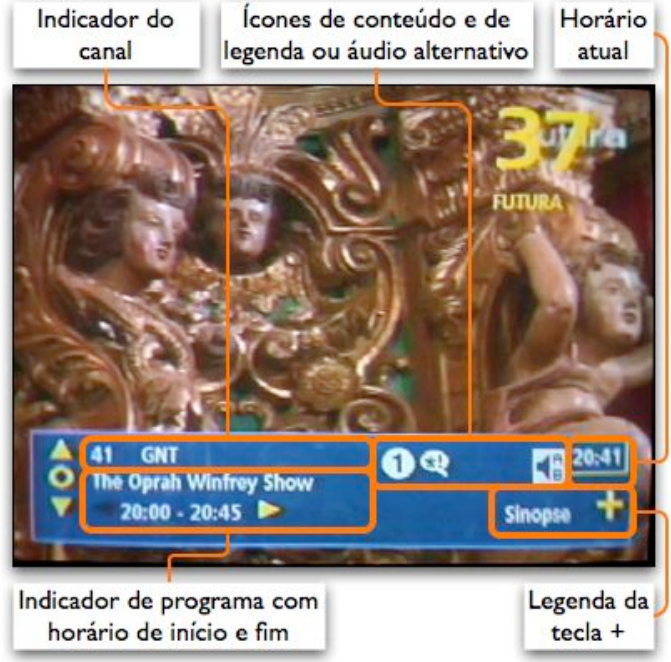

Figura 4-75 - Detalhes da tarja de informações da plataforma SKY
Ao ser ativada a tarja de informações das duas plataformas SKY aparece na parte inferior da tela (Figura 4-74 e Figura 4-75). Esta tarja desliza da borda inferior do vídeo até sua posição quando aparece e some novamente pela borda inferior do vídeo. É um do poucos exemplos do uso de transições em interfaces de TVi. Além de mostrar o programa atual e próximo nos diversos canais, é possível navegar por esta tarja por horários futuros até o limite

de 24 horas. Ao trocar de canal, porém, o horário selecionado volta para o horário atual.

Ao pressionar a tecla + o usuário vai para a tarja de sinopse, que mostra uma descrição textual do programa. Quando não há descrição aparece simplesmente um retângulo azul no mesmo formato e posição da tarja de infor- 
mações, sem conteúdo algum. Pressionando a tecla + novamente o usuário volta para a tarja de informação. Nesta tarja também há vários ícones indicativos sobre o programa. O primeiro ícone é um número relativo à classificação etária do programa, mas não fica claro que número é referente a qual classificação. À direita deste aparecem alguns ícones sobre o conteúdo do programa (linguagem imprópria, violência, etc.). Por último aparece um ícone que indica a existência de áudio e legenda alternativo.

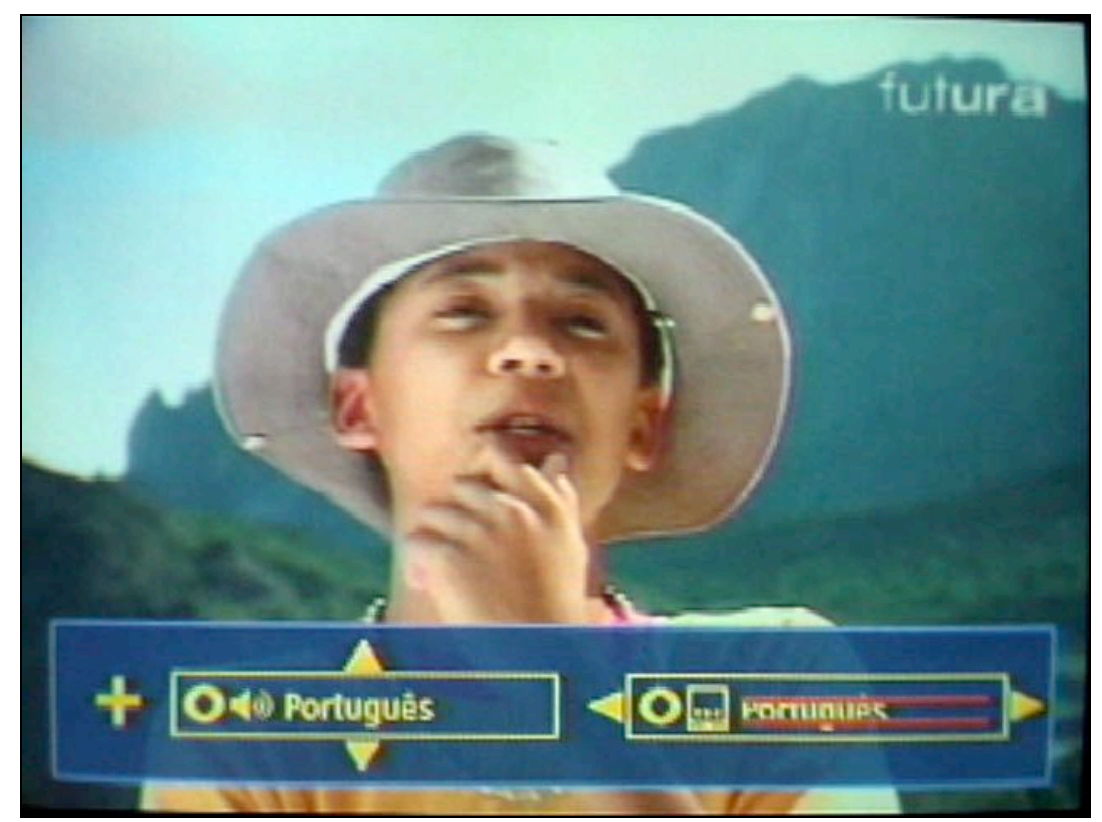

Figura 4-76 - Tarja de áudio e legenda alternativos da plataforma SKY

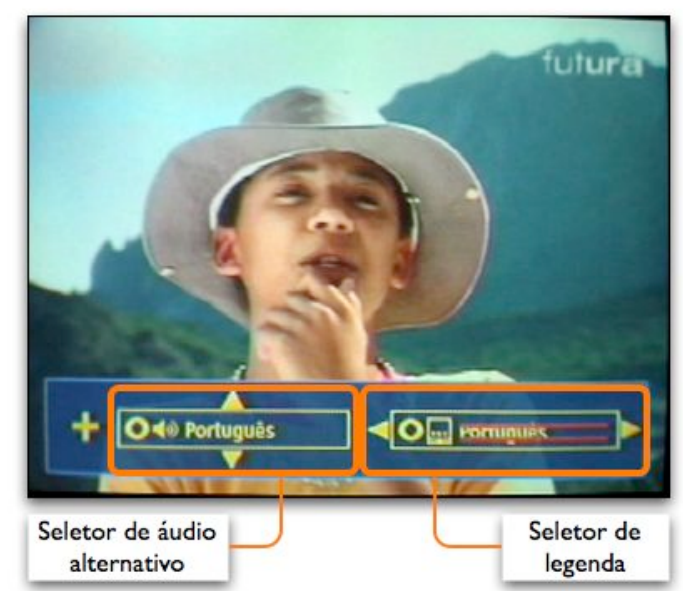

Figura 4-77 - Detalhes da tarja de áudio e legenda alternativos da plataforma SKY
Ao pressionar a tecla + sem a tarja de informações ativada o usuário vai para a tarja de opções de áudio e legenda alternativos (Figura 4-76 e Figura 4-77). Nesta tela o usuário utiliza as setas verticais para trocar de áudio e as horizontais para trocar de legenda. Um problema desta funcionalidade é que caso o áudio esteja ajustado para inglês alguns canais nacionais ficam mudos, outros não, o que é confuso. 
As opções da legenda também não são claras. Na tela apresentada aparece a opção Português com um risco duplo e a outra opção é Nenhum e o programa não tem legendas. Em outros casos o programa tem legendas mas selecionar a opção Nenhum não faz efeito. Para sair desta tarja o usuário deve pressionar novamente a tecla + ou pressionar a tecla de confirmação.

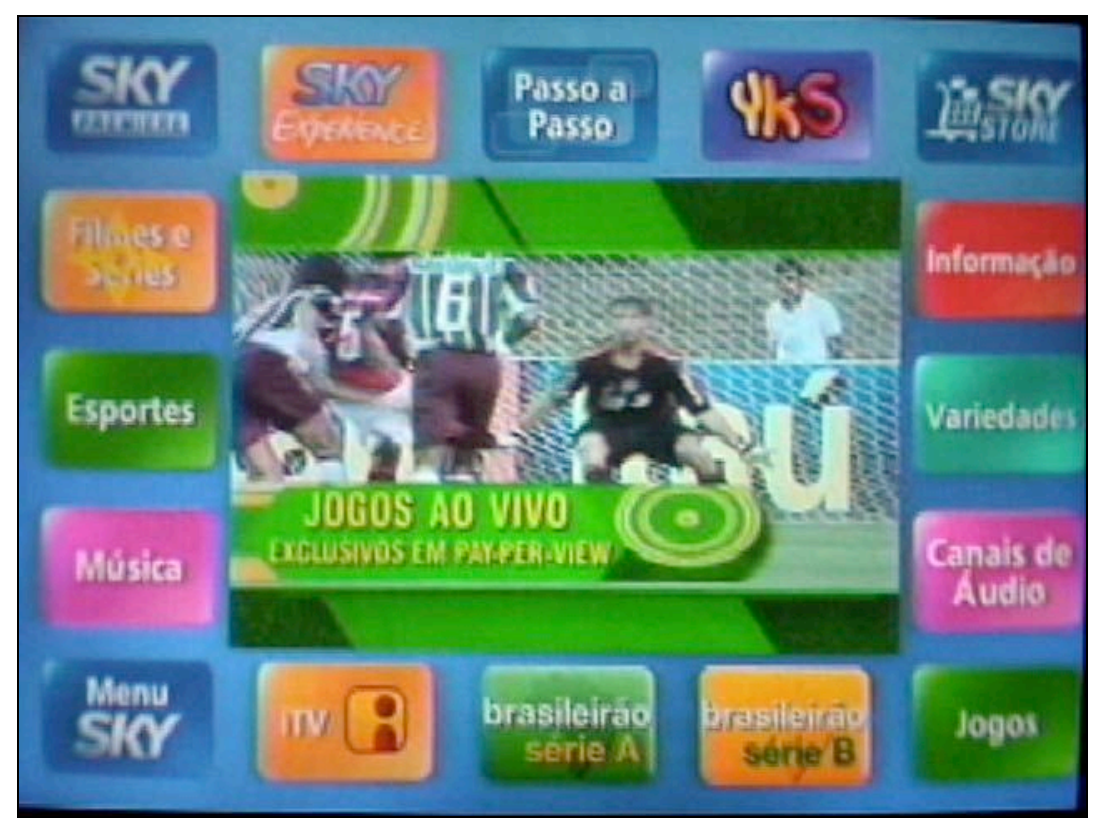

Figura 4-78 - Tela de mosaico principal da plataforma SKY

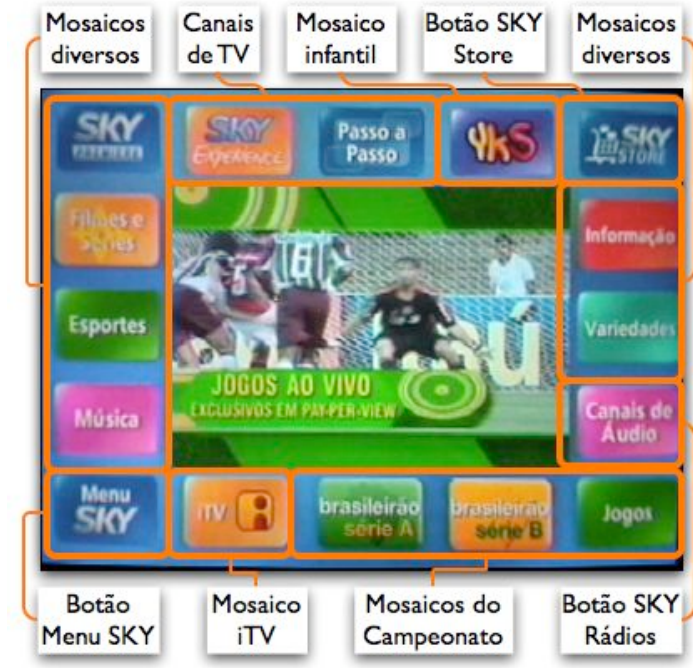

Figura 4-79 - Detalhes da tela de mosaico principal da plataforma SKY
Sempre que o sistema é ligado vai para a tela Mosaico, que é o ponto de partida para a navegação pelo sistema (Figura 4-78 e Figura 4-79). Ela apresenta 16 botões ao redor de um vídeo que podem levar para um canal, outro mosaico, um aplicativo de TVi ou o menu de configuração.

Não existe um arranjo destes botões em grupos de afinidades, nem por posição, nem por cor nem por acabamento dos botões, o que dificulta a formação de uma imagem do sistema por parte do usuário. O cur- 
sor também é de difícil leitura, principalmente quando está sobre os ícones de cor alaranjada.

Os aplicativos de TVi acessíveis a partir desta tela são: uma loja virtual (botão SKY Store, 20 segundos para carregar), um aplicativo de rádios (botão Canais de Áudio, 10 segundos para carregar) e o mosaico de aplicativos de TVi (botão iTV, 12 segundos para carregar). Caso o usuário selecione um destes três botões irá para uma tela que diz "Se o seu terminal de acesso tem os recursos iTV, aguarde", e o sistema não responde a comandos até carregar o aplicativo. Não fica claro o que aconteceria se o terminal de acesso não tivesse os recursos iTV. Caso o usuário se engane e pressione Canais de Áudio ao invés de Música ele não pode corrigir rapidamente o erro e tem que aguardar o carregamento do aplicativo para depois desfazê-lo.

Os dois canais de TV acessíveis a partir desta tela são da SKY. Um deles (SKY Experience) é um canal promocional e o outro (Passo a Passo) é um canal de ajuda não-interativo. 


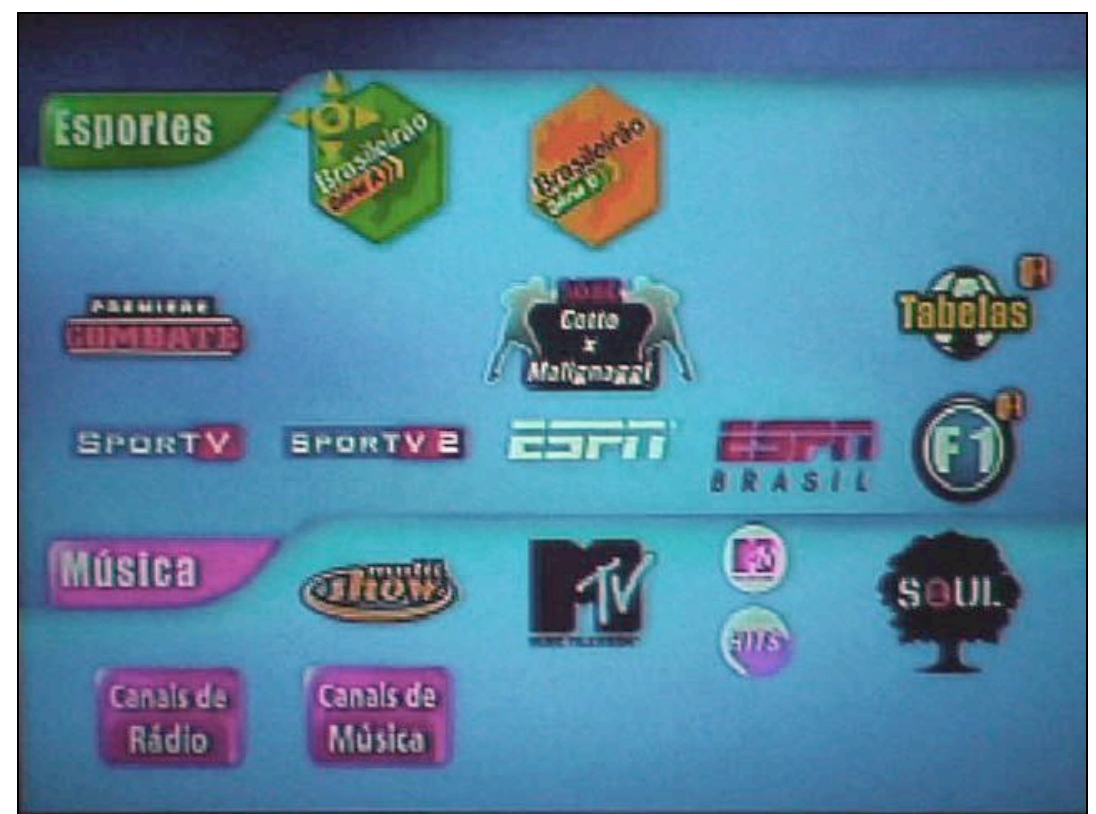

Figura 4-80 - Tela de mosaico de esportes da plataforma SKY

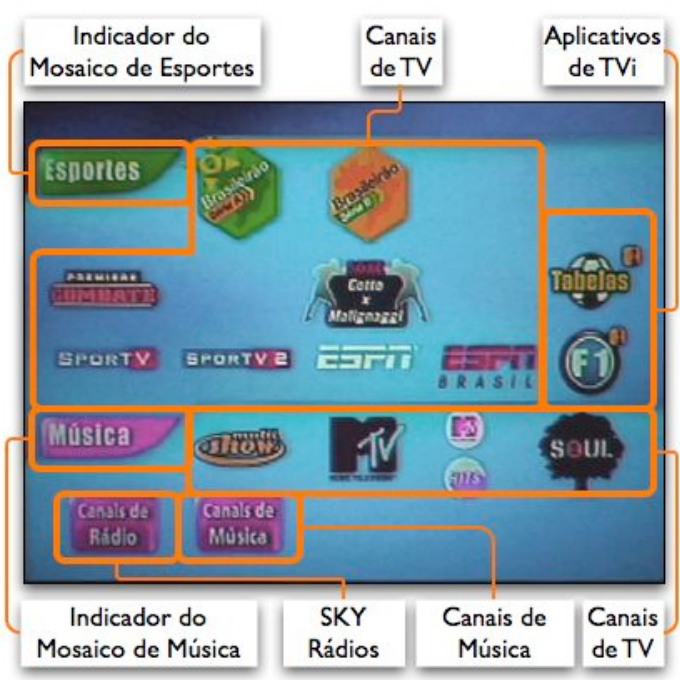

Figura 4-81 - Detalhes da tela de mosaico de esportes da plataforma SKY
Os mosaicos normalmente ocupam uma tela, com o vídeo no meio ou não, e alguns mosaicos (Filmes e Pay-per-view) têm duas telas. Esta tela, no entanto, tem 2 mosaicos e acionando os botões de Esportes ou de Música na tela inicial o usuário vem para esta tela.

Nesta tela o botão para as rádios tem o nome de Canais de Rádio, enquanto que no menu inicial chama-se Canais de Áu-

dio. O ícone com a letra i mostra dois botões que vão para aplicativos. Outros canais que têm aplicativos de TVe também têm este ícone.

O áudio desta tela é o áudio do último canal visitado. Os mosaicos também são "canais" neste sistema; portanto se o usuário digitar 200 no teclado numérico irá para o portal principal, se digitar 203 virá para o portal de esportes e música. 


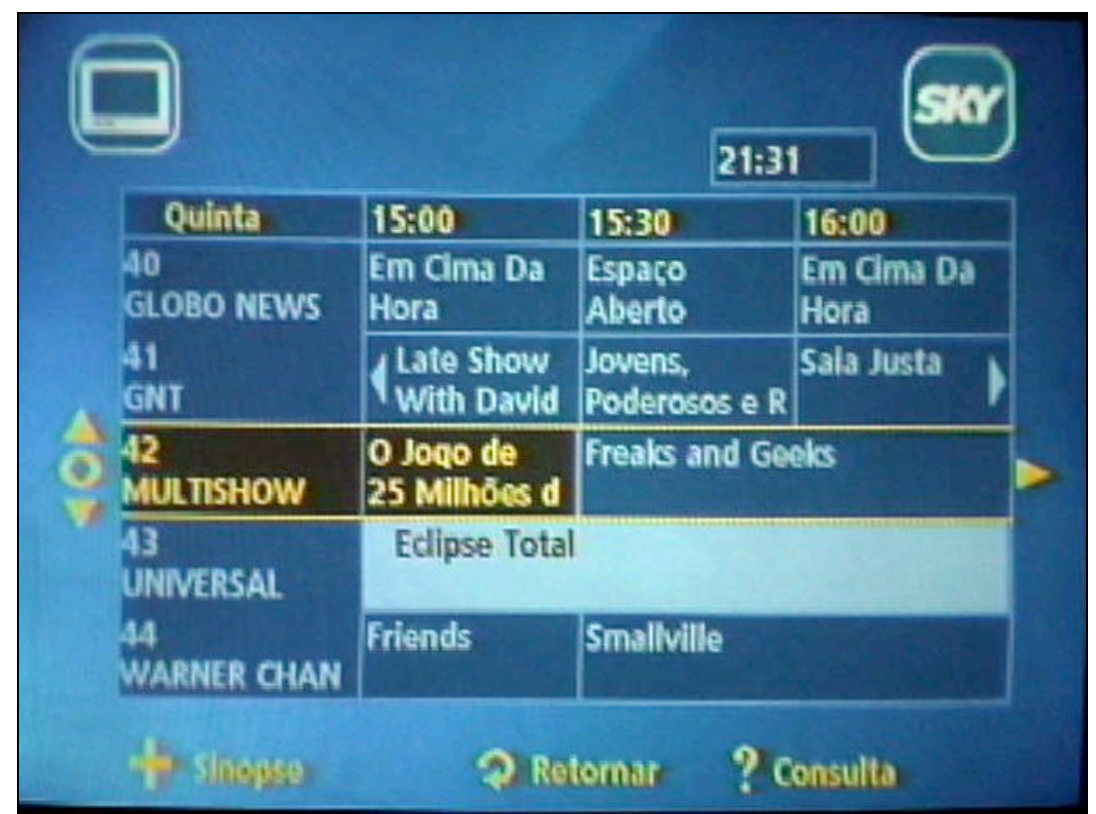

Figura 4-82 - Guia de programação da plataforma SKY

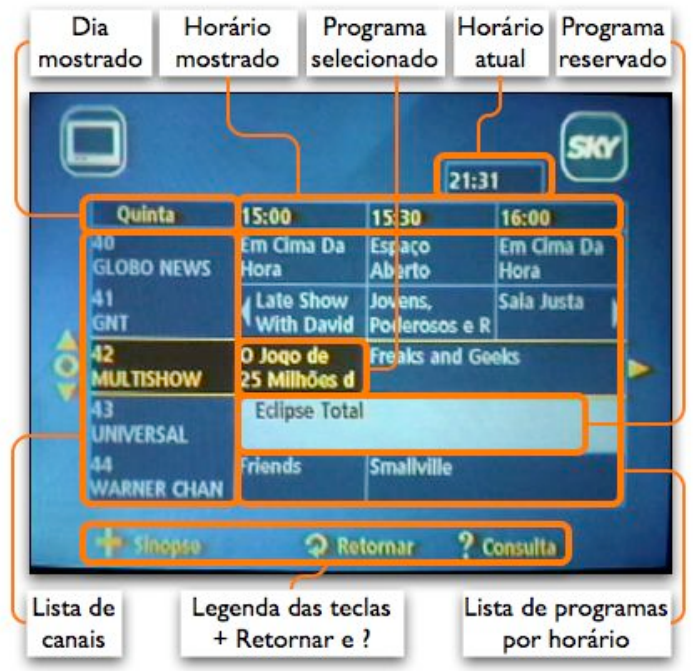

Figura 4-83 - Detalhes do guia de programação da plataforma SKY
O guia de programação desta plataforma utiliza o mesmo paradigma da DirecTV, com uma tabela onde as linhas são os canais e os diferentes horários são as colunas (Figura 4-82 e Figura 4-83). Tem um melhor arranjo da tela, que permite ver 5 canais e uma hora e meia de programação. Utiliza uma fonte maior, mais espaçamento, cores mais suaves e duas linhas de texto por canal, o que facilita a leitura.

Utilizando as setas verticais o usuário seleciona o canal e com as setas horizontais seleciona o horário. Nesta plataforma o item selecionado fica sempre no meio da tela e o que se move é o conteúdo. Por exemplo, ao selecionar seta para cima o canal 41 ocupa o lugar do canal 42 e assim sucessivamente. Como o significado das teclas no controle remoto não é claro é necessária uma legenda na tela para explicar suas funções. A tecla + apresenta uma tela de sinopse e a tecla ? (que tem legenda de Consulta) apresenta uma tarja para navegar para um dia ou horário específico 
na grade de programação. Neste guia de programação não há uma imagem do vídeo, mas ele mantém o áudio do último canal visitado.

Ao selecionar um programa atual ele vai para o canal selecionado. Caso o programa selecionado seja em um horário futuro o usuário vai para a tela de informações do programa. Um programa reservado fica marcado em azul claro.

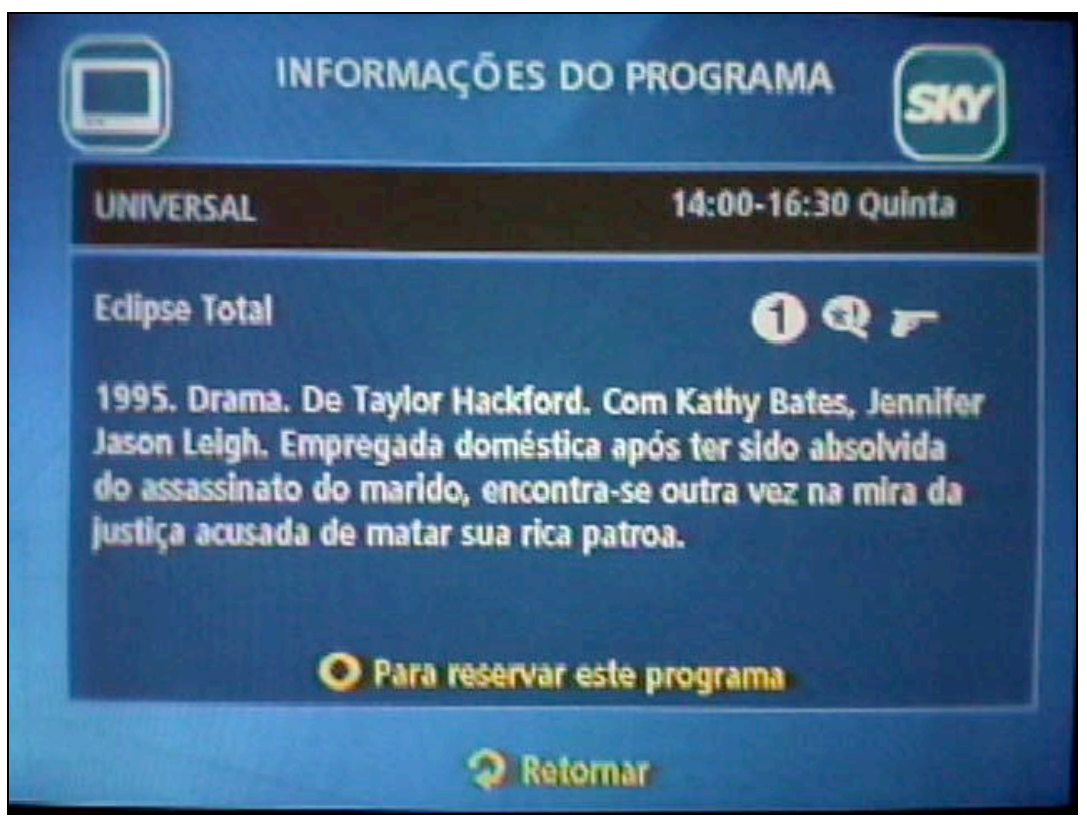

Figura 4-84 - Tela de informações do programa da plataforma SKY

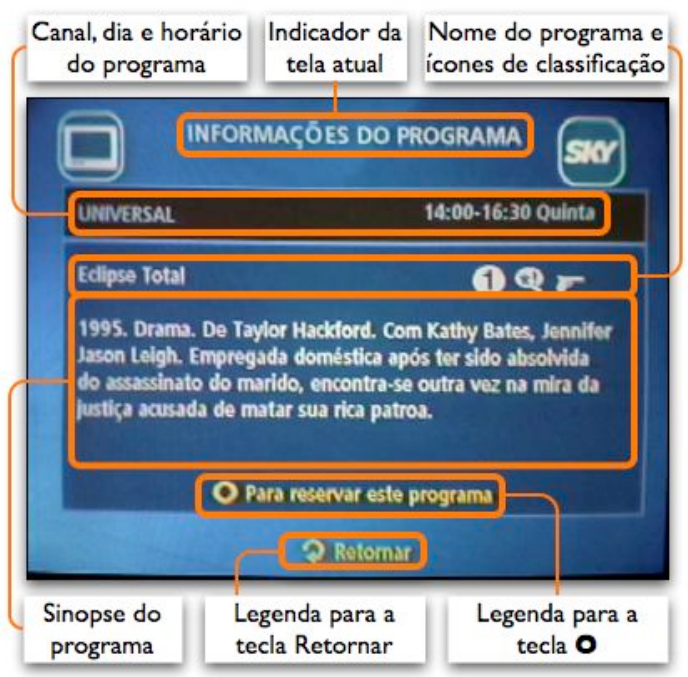

Figura 4-85 - Detalhes da tela de informações do programa da plataforma SKY
Na tela de informações do programa (Figura 4-84 e Figura 4-85) o usuário pode reservar um programa. Esta tela é idêntica à tela de sinopse com exceção do texto que diz "O Para reservar este programa" que não existe na tela de sinopse, o que pode confundir o usuário.

\section{Para reservar o pro-}


grama o usuário deve pressionar o tecla de confirmação, e irá para uma tela com a lista de programas reservados. Pressionando a tecla Retornar na lista de programas reservados o usuário volta para o guia de programação. Se quiser voltar para esta tela deve pressionar a tecla.+

\begin{tabular}{|c|c|c|c|c|c|c|c|}
\hline \multicolumn{6}{|c|}{ Grasileiräo \ serie A } & \multicolumn{2}{|c|}{ 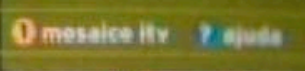 } \\
\hline $\mathrm{CLO}$ & ssifica & $\mathrm{ACRO}$ & & & Lat & e jocos & SERII A \\
\hline CLASSIACAÇĀO & PIS & J & V & E & D & GP GC S & SG \\
\hline Cruzeiro & 21 & 10 & 6 & 3 & 1 & 208 & 12 \\
\hline Internacional & 21 & 10 & 6 & 3 & 1 & $16 \quad 11$ & 5 \\
\hline São Paulo & 20 & 10 & 6 & 2 & 2 & 178 & 9 \\
\hline Fluminense & 19 & 10 & 6 & 1 & 3 & $1510:$ & 5 \\
\hline Santos & 18 & 10 & 5 & 3 & 2 & 136 & 7 \\
\hline Golás & 17 & 10 & 5 & 2 & 3 & 1210 & 2 \\
\hline Paraná & 15 & 10 & 4 & 3 & 3 & 1811 & 7 \\
\hline Figueirense & 15 & 10 & 4 & 3 & 3. & $15 \quad 12$ & 3 \\
\hline Grêmio & 15 & 10 & 4 & 3 & 3 & 1414 & 0 \\
\hline Aproveite! Pres & so im & perd & & & & Tone1 & they \\
\hline
\end{tabular}

Figura 4-86 - Aplicativo com tabela de jogos de campeonato de futebol da plataforma SKY

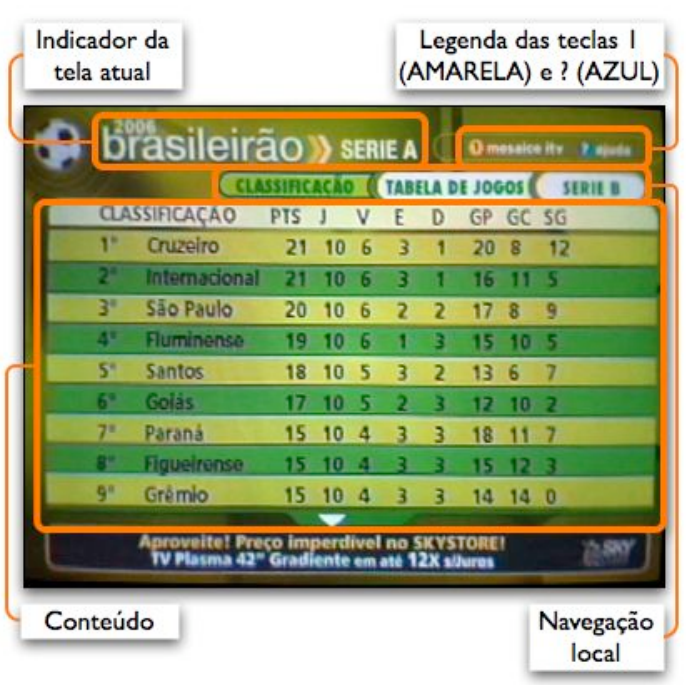

Figura 4-87 - Detalhes do aplicativo com tabela de jogos de campeonato de futebol da plataforma SKY
Este aplicativo da SKY mostra a tabela de jogos do campeonato Brasileirão 2006, séries A e B. Nesta tela (Figura 4-86 e Figura 4-87), está a classificação dos times no campeonato.

Pelas setas horizontais é possível ver a tabela de jogos e selecionar o botão da série B. Para ir para a série $B$ é preciso ir ao botão da série B e confirmar, quando este botão passa a ser o botão da série A. 
Pelas setas verticais é feita a rolagem do conteúdo na tela. A tecla 1 ou amarela leva de volta para o mosaico iTV, enquanto que a tecla ? ou azul aciona a ajuda.

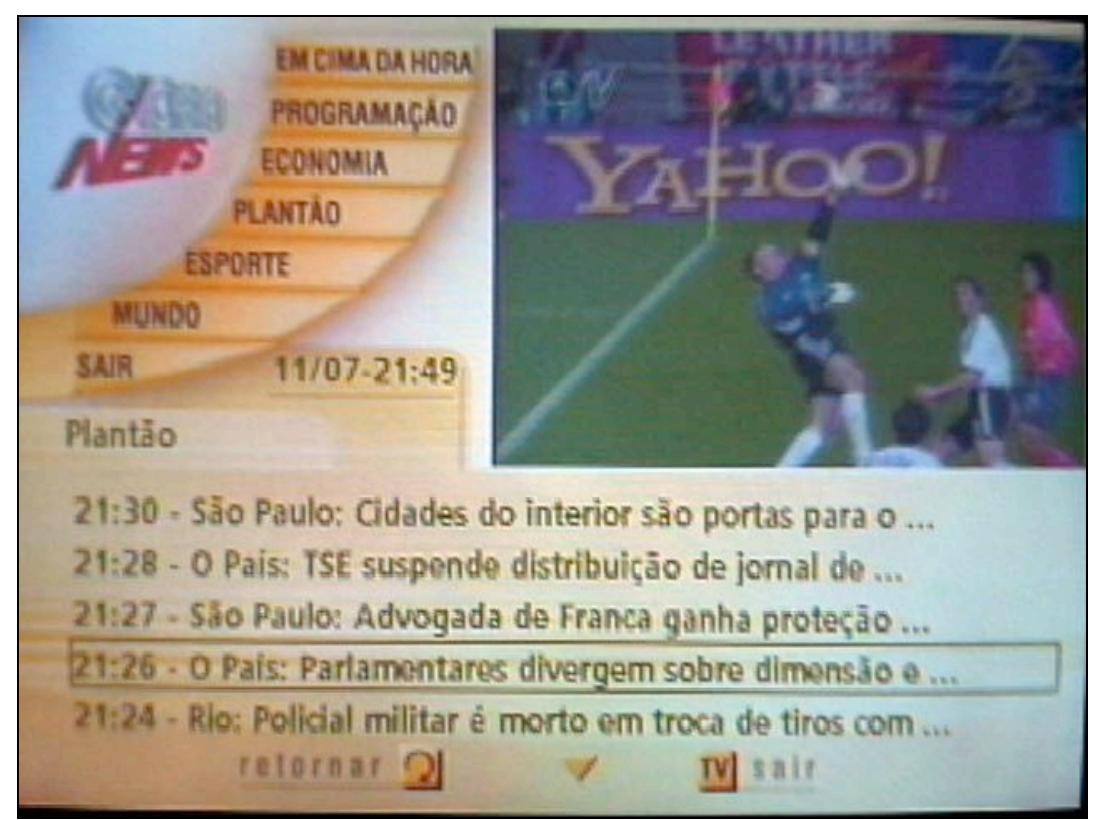

Figura 4-88 - Programa de TVe do canal Globo News

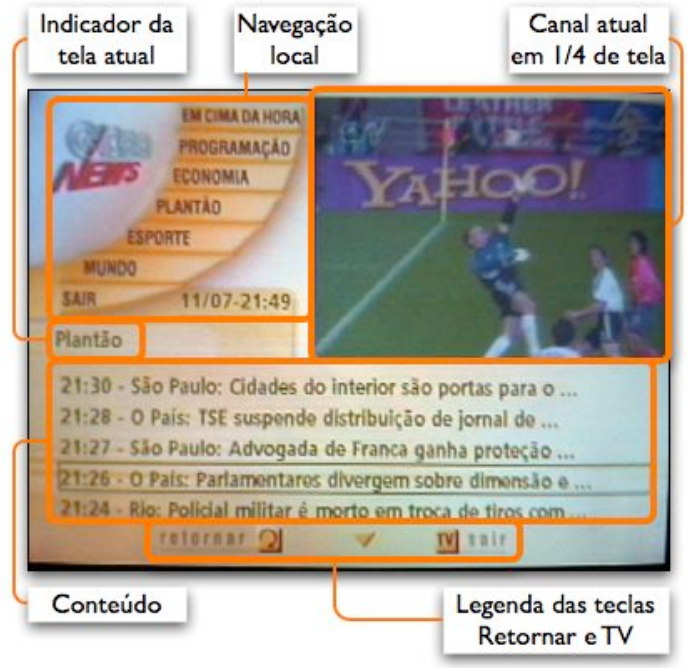

Figura 4-89 - Detalhes do programa de TVe do canal Globo News
Ao sintonizar o canal Globo News na plataforma SKY e aguardar alguns segundos (aproximadamente 15 segundos) aparece um ícone com a letra i no canto superior direito da tela, indicando a presença de conteúdo interativo para aquele canal. Ao pressionar a tecla i (tecla com a letra i) do controle remoto o usuário vai para a tela dos aplicativos de TVe (Figura 4-88 e Figura 4-89).

Quando carrega o aplicativo está com uma das notícias selecionadas (que leva aproximadamente mais 15 segundos). Utilizando as setas verticais é possível selecionar as outras notícias e a tecla de confirmação abre a no- 
tícia. As páginas da notícia são viradas através das setas verticais e a tecla de Retornar volta para a lista de notícias.

Pressionando novamente a tecla Retornar o cursor vai para o menu de navegação local (apesar de não ter passado por lá ainda), no canto superior esquerdo. Para selecionar notícias em um outro assunto o usuário deve usar as setas verticais e confirmar com a tecla de confirmação.

Alternativamente à tecla i, a ativação do aplicativo de TVe também pode ser feita através da tecla de confirmação. No entanto, se o usuário pressionar esta tecla antes do ícone de i aparecer na tela ou em um canal que não tenha conteúdo interativo ele é direcionado para a tela do Menu SKY, causando uma certa confusão. 


\section{Dispositivos da Plataforma}

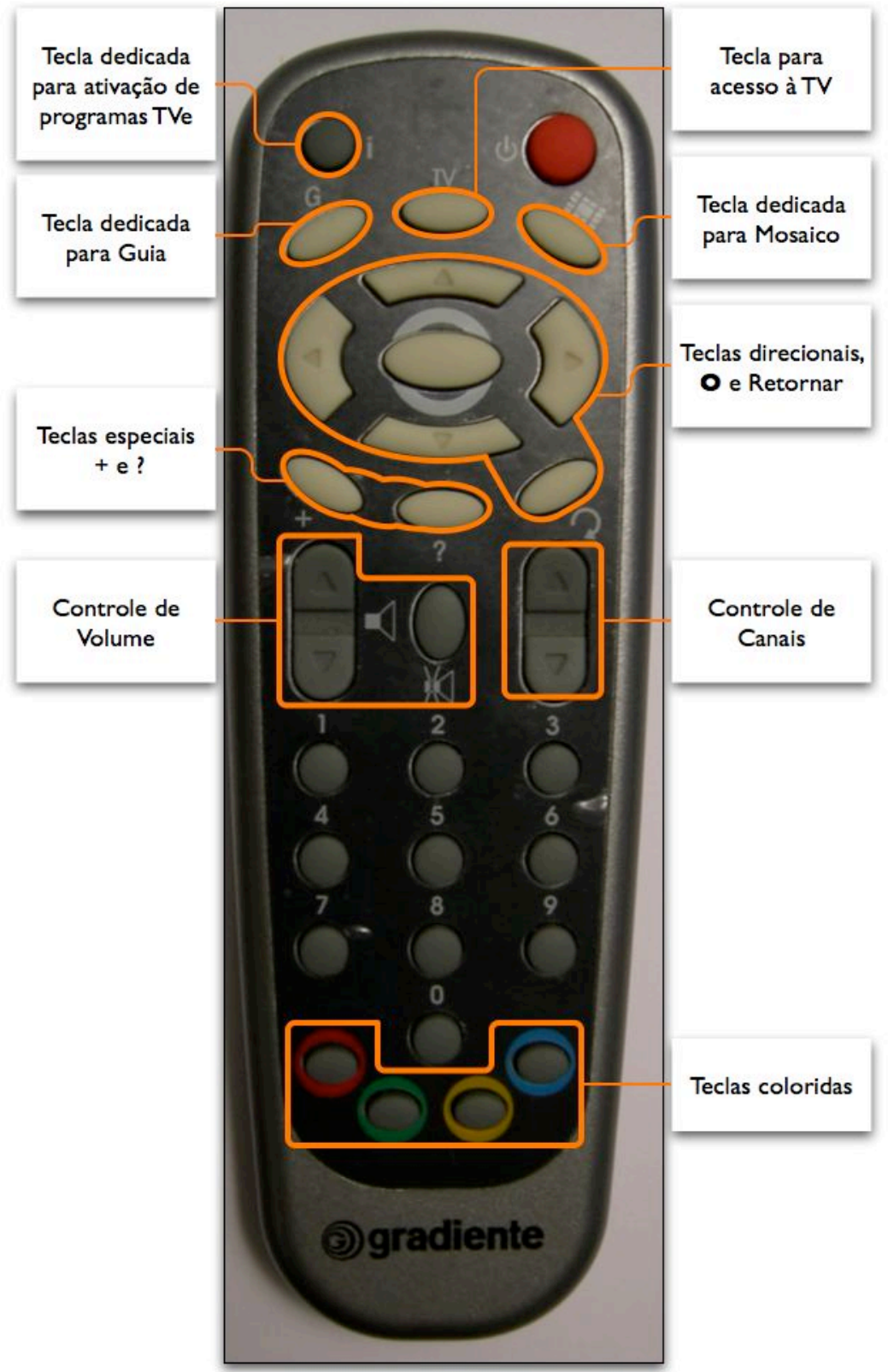

Figura 4-90 - Controle remoto da plataforma SKY

No controle remoto da SKY (Figura 4-90) aparece a tecla i, utilizada para ativação de programas de TVe. A tecla de confirmação também ativa estes aplicativos e portanto a tecla i não é necessária.

Abaixo dela estão três atalhos para telas, o guia de programação $(G)$, sair para TV (TV) e o mosaico principal (ícone próprio do mosaico). 
As setas direcionais tem a configuração padrão, com o botão de confirmação no centro, mas a legenda para este botão é um círculo (O), que fica encoberto pelo próprio botão. A tecla de volta fica abaixo à direita.

Abaixo das setas direcionais também estão duas teclas com funções variadas na plataforma SKY, a tecla + e a tecla ?. Abaixo destas estão os controles de canal e volume e a tecla de mudo.

As legendas deste controle são de difícil compreensão. Elas não utilizam palavras e misturam ícones conhecidos (volume, volta) com ícones próprios (mosaico, +), e letras (G, i). As legendas também não estão bem posicionadas e criam uma ambigüidade quanto a que tecla se referem. As teclas para controle de canal não têm legenda.

No total o controle tem 32 teclas. 


\section{Navegação da Plataforma}

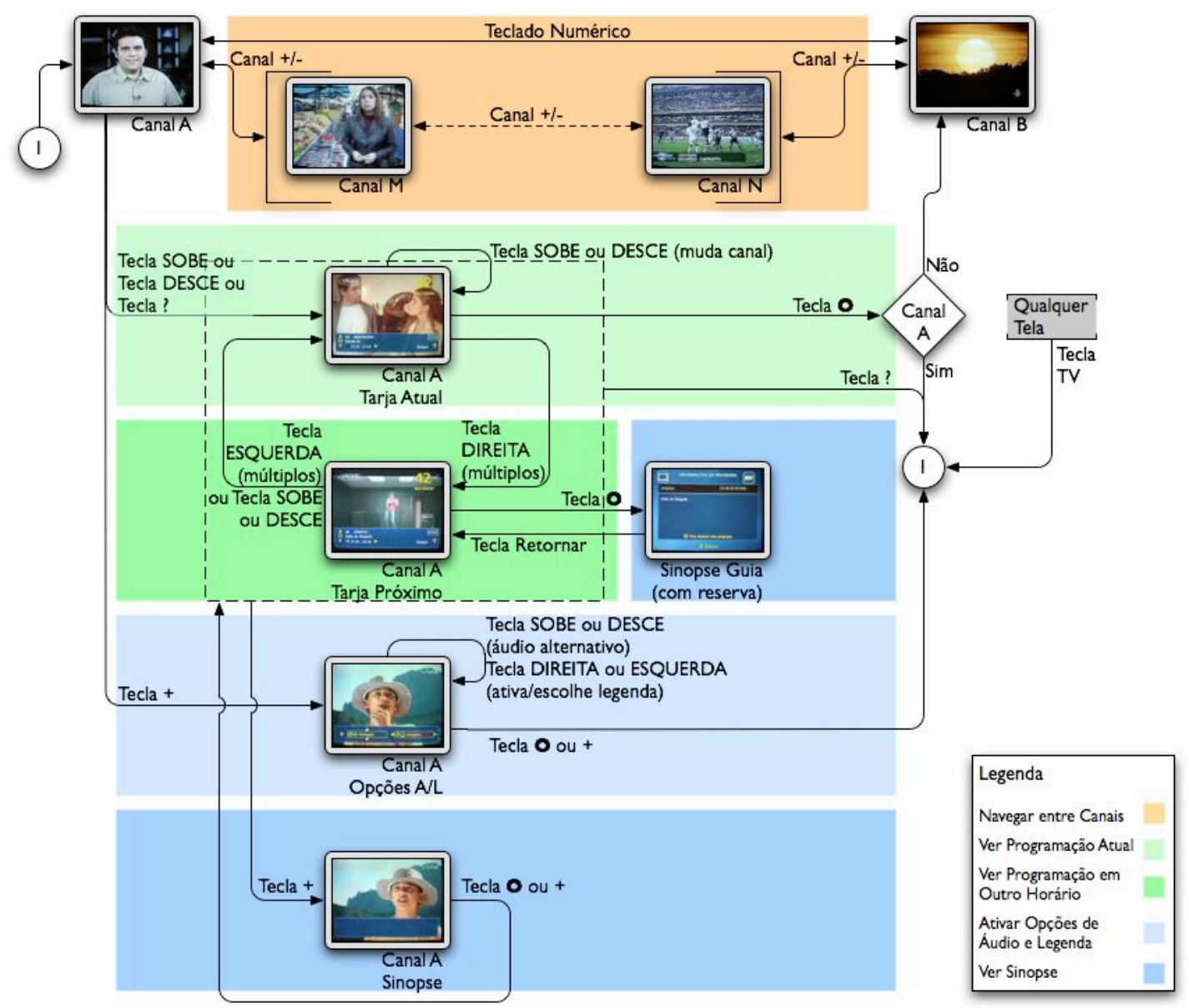

Figura 4-91 - Navegação de TV da plataforma SKY

A tarja de informações nesta plataforma (Figura 4-74) é ativada pelas setas verticais ou pela tecla ?. Pelas verticais se muda de canal e pelas setas horizontais é possível ver não só o programa atual e o próximo, mas todos os programas nas 24 horas seguintes. Uma diferença desta plataforma é que sempre que se muda de canal o programa selecionado volta para o atual.

Caso o usuário selecione na tarja um programa no horário atual ele vai para canal correspondente, caso selecione um programa em horário futuro vai para uma tela de sinopse (Figura 4-84) que permite reservar o programa (o sistema avisa quando o programa está para começar). Desta tela de sinopse o usuário pode utilizar a tecla de volta (Retornar) para retornar à tela de TV.

De maneira similar à plataforma anterior a tecla de volta também tem funcionamento diferente se estiver no contexto de TV ou em outras telas do 
sistema. No contexto de TV ela alterna entre os dois últimos canais sintonizados enquanto em outros contextos funciona como um histórico de telas. Por este motivo a tela de reserva de programa é a única tela de navegação pela TV que utiliza esta tecla.

Estando aberta a tarja, a tecla + leva para uma tela de sinopse sobre o vídeo. Para sair desta tela utiliza-se a tecla de confirmação ou a tecla +. No contexto de TV as teclas ? e + são utilizadas para ativar e desativar uma função (uma tecla de liga-desliga), pressionadas uma vez ativam e pressionadas novamente desativam.

Caso a tarja esteja fechada esta mesma tecla mostra as opções de áudio e legendas alternativas (Figura 4-76). Estas opções são modificadas pelas setas direcionais, sendo o áudio pelas setas verticais e a legenda pelas setas horizontais. Em qualquer situação a tecla TV (Sair nas plataformas anteriores) pode ser utilizada como um atalho para a tela da TV.

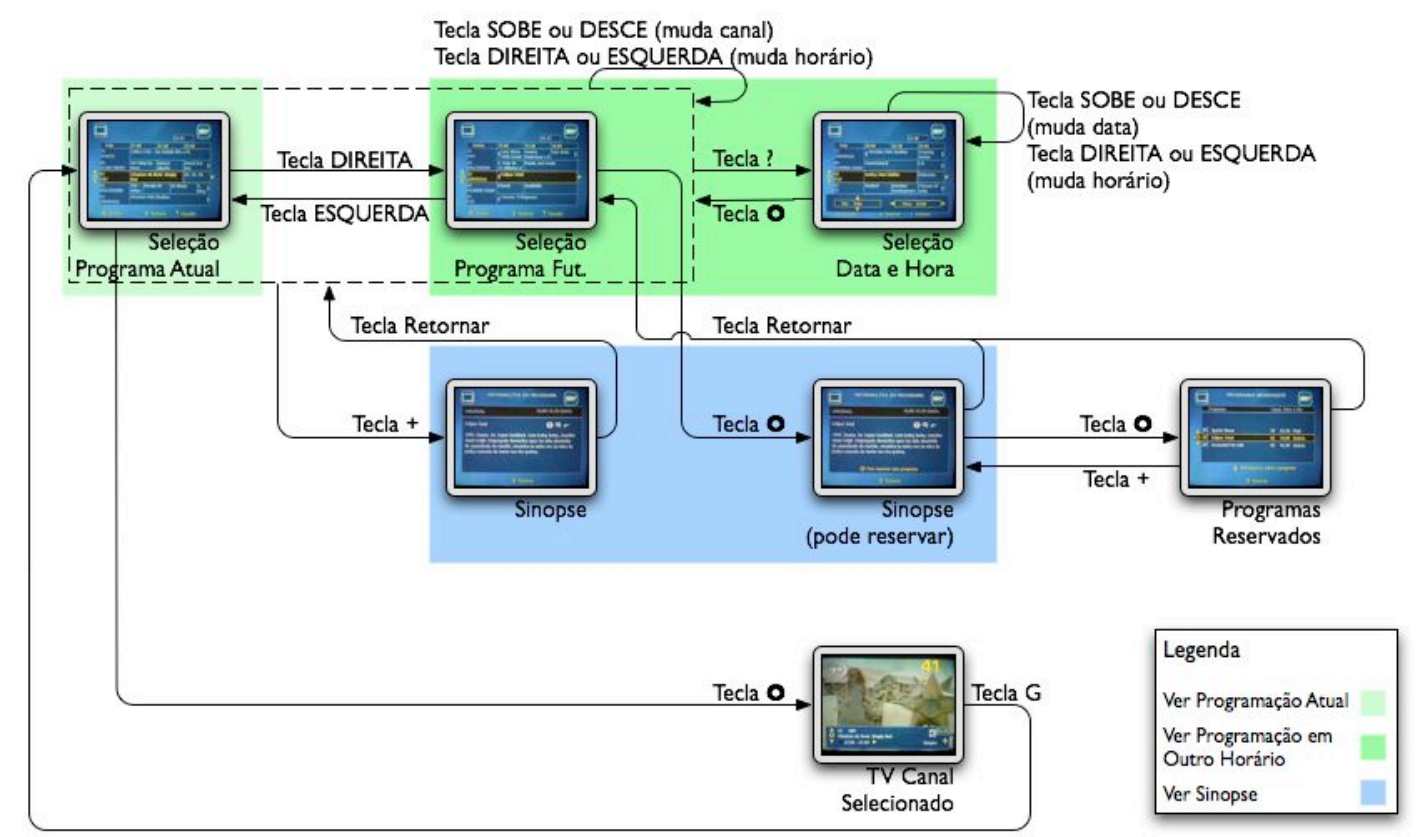

Figura 4-92 - Navegação do guia de programação da plataforma SKY

O guia de programação desta plataforma retoma o arranjo das informações em grade, com um canal por linha e os diferentes horários nas colunas (Figura 4-82). As setas verticais selecionam os diferentes canais e as setas horizontais selecionam os horários. 
Pressionando a tecla de confirmação sobre um programa atual o usuário é levado para o canal selecionado. Caso seja um programa futuro o usuário vai para a mesma tela de reserva de programa (Figura 4-84) que acessa pela tarja de informações na navegação pela TV.

Para ver a sinopse do programa selecionado o usuário utiliza a tecla + . Para fechar a sinopse é necessário utilizar a tecla de volta pois nesta situação a tecla de + não funciona para desativar a tela de sinopse.

Para ir para outra data ou horário o usuário ativa uma tarja pela tecla ?, semelhante à tarja para escolha de áudio e legenda alternativa (Figura 4-76). Nesta tarja as setas verticais trocam o dia e as setas horizontais trocam a hora e a tarja pode ser desativada tanto pela tecla ? quanto pela tecla de confirmação.

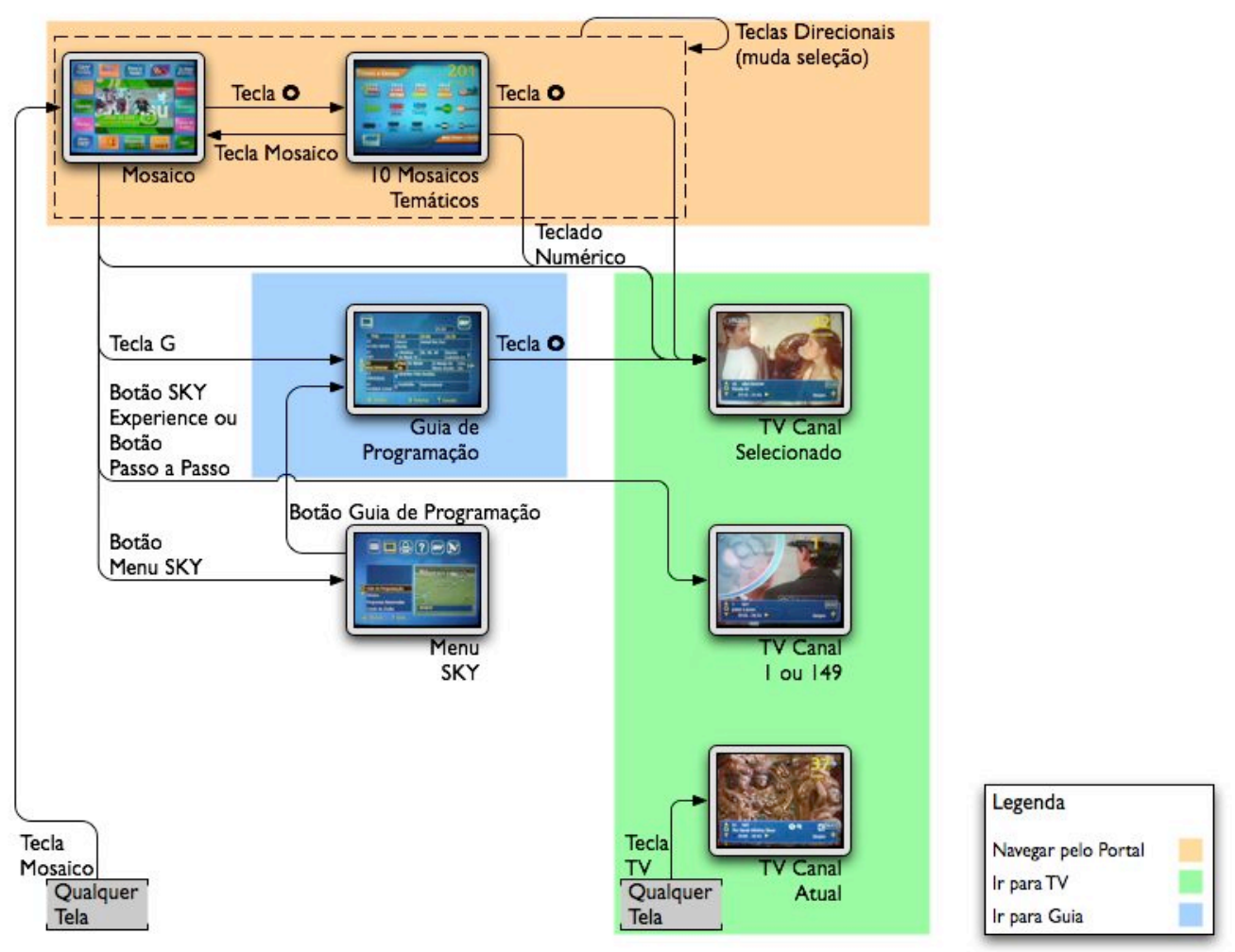

Figura 4-93 - Navegação do portal da plataforma SKY

O arranjo visual das telas do mosaico (o portal desta plataforma, Figura 4-78) não é bem organizado e a estrutura entre telas também é complexa, com muitas ligações entre telas internas e entre níveis hierárquicos diferentes. A navegação entre estas telas acaba ficando complexa, apesar de ser muito sim- 
ples em termos das teclas utilizadas. As setas direcionais selecionam os botões na tela e a tecla de confirmação é utilizada para ir para a tela selecionada. Se o botão selecionado for o ícone de um canal, vai para o canal, se for um aplicativo de TVi, ativa o aplicativo e se for outro mosaico, vai para o mosaico.

Um problema acontece com a tecla de voltar. Apesar de os mosaicos terem uma estrutura de menus e sub-menus a função de voltar funciona como se os mosaicos fossem canais, ou seja, alterna entre os dois últimos mosaicos selecionados ao invés de voltar progressivamente até o mosaico inicial.

O guia de programação é acessível por uma tecla dedicada no controle remoto. Para navegar até o guia é necessário primeiro ir para o Menu SKY e de lá ir para o guia de programação. Do guia de programação o usuário acessa a TV no canal selecionado.

O Menu SKY tem uma navegação local por várias telas e quando se acessa este menu ele não abre sempre na mesma tela, mas na tela que foi deixado. Desta forma, ao abrir o Menu SKY o usuário pode entrar na tela de onde acessa o guia de programação ou não.

Também é possível acessar a TV a partir de dois botões no mosaico principal, mas são canais de promoções da plataforma (SKY Experience) e um canal explicativo não-interativo (Passo a Passo). A tecla TV leva o usuário diretamente para a TV, no último canal sintonizado. 


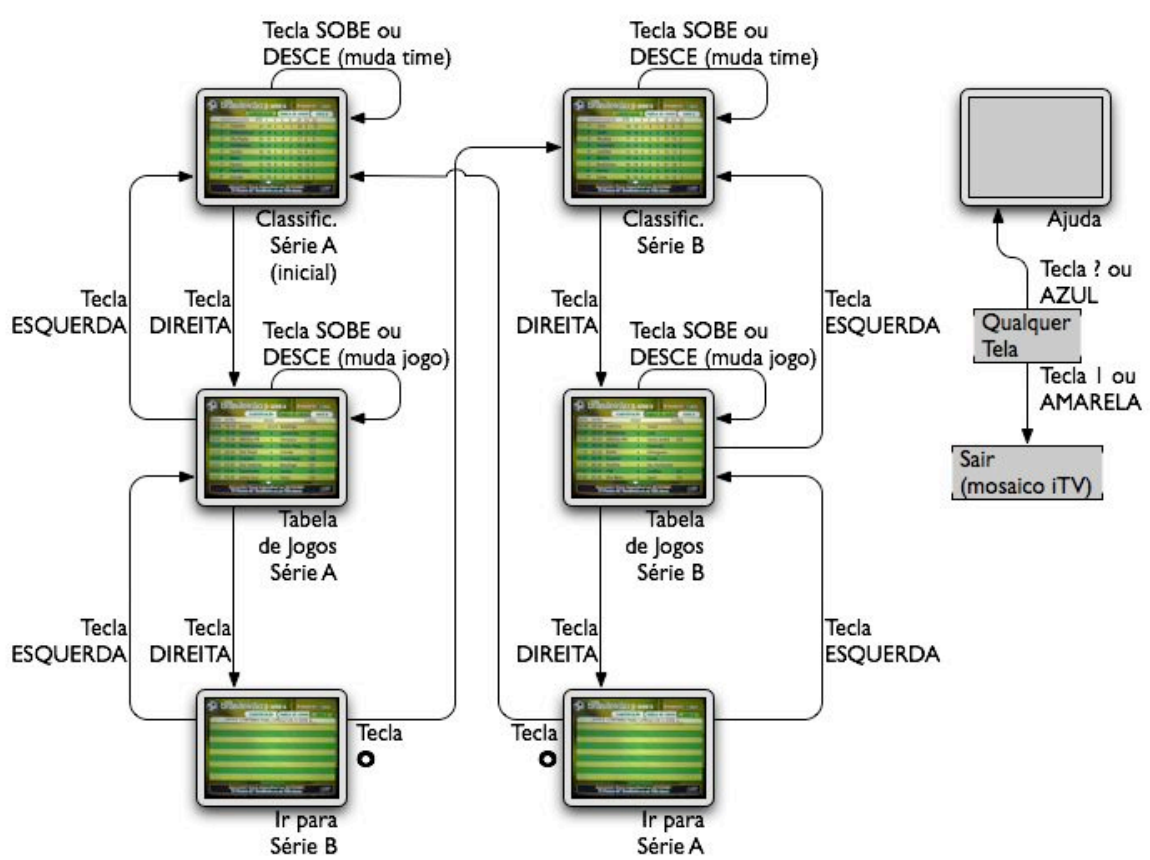

Figura 4-94 - Navegação do aplicativo com tabela de jogos de campeonato de futebol da plataforma SKY

Este aplicativo tem seis telas no total, divididas em dois grupos de três telas cada, sendo quatro de conteúdo e duas apenas para navegação.

A tela inicial (Figura 4-86) mostra a classificação dos times na série A do campeonato em uma lista, as setas verticais são utilizadas para rolagem da lista. Ao acionar a seta para a direita a tela muda para a tabela de jogos da séria A e as setas verticais mudam de jogo. Para voltar para classificação o usuário deve pressionar a tecla para a esquerda.

Para ver os dados (classificação e tabela de jogos) da série B o usuário deve pressionar novamente a tecla para a direita, ir para uma outra tela (que não tem conteúdo) e pressionar a tecla de confirmação, indo para a tela de classificação da série B.

Assim, este aplicativo mistura uma navegação por teclas horizontais sem confirmação (basta apertar a tecla) com uma navegação onde é necessário a confirmação (seleciona pelas setas e confirma pela tecla de confirmação).

Neste aplicativo a tela de ajuda (um texto explicativo) é acessada pela tecla ? ou pela tecla azul. A tecla 1 do teclado numérico e a tecla amarela saem do aplicativo e retornam para o mosaico iTV. 


\subsubsection{Plataforma SKY+}

\section{Descrição da Plataforma}

A plataforma SKY+ é praticamente idêntica à plataforma SKY, mas oferece recursos adicionais de PVR (Personal Video Recorder) que permitem a gravação de programas para serem vistos posteriormente. Das plataformas analisadas é a que apresenta recursos mais avançados. 
Mapa de Navegação da Plataforma

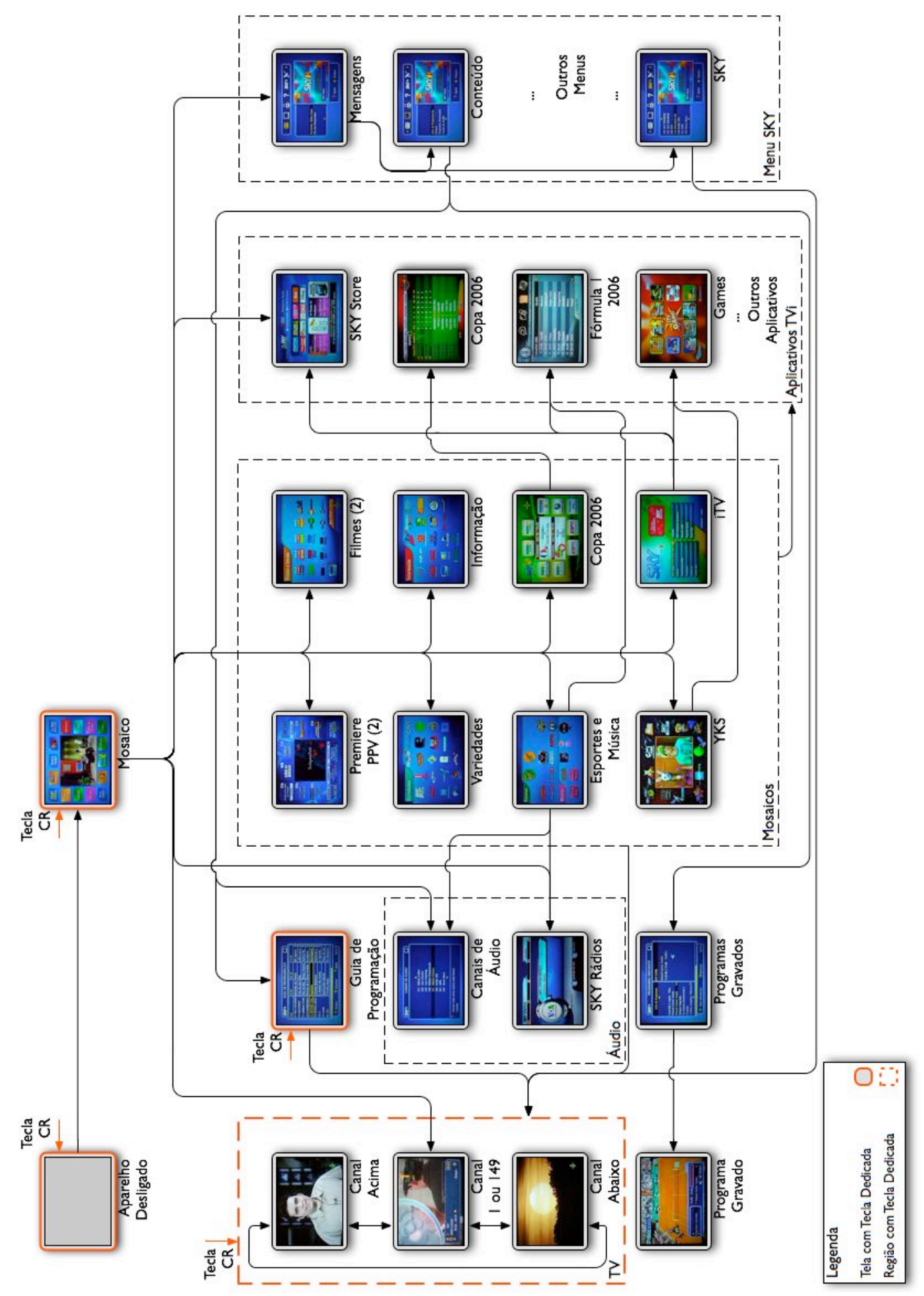

Figura 4-95 - Mapa de navegação da plataforma SKY+ 
Por ser quase idêntica à plataforma anterior, apresenta as mesmas características e problemas já citados.

Uma das poucas diferenças desta plataforma é que tem uma tela que funciona como um guia de programação para os programas gravados, que apresenta uma lista dos programas gravados com uma sinopse para cada um. Ao selecionar um dos programas desta tela o usuário começa a assistir ao programa.

Mesmo sendo o grande diferencial desta plataforma, o acesso ao conteúdo gravado não é fácil. Do mosaico inicial é necessário ir ao menu de configuração (Menu SKY), dentro dele navegar e selecionar Programas Gravados para então ter acesso à lista de programas e selecionar o desejado. Para um item que se espera que seja bastante utilizado ele está mal colocado na estrutura de navegação. 


\section{Telas da Plataforma}

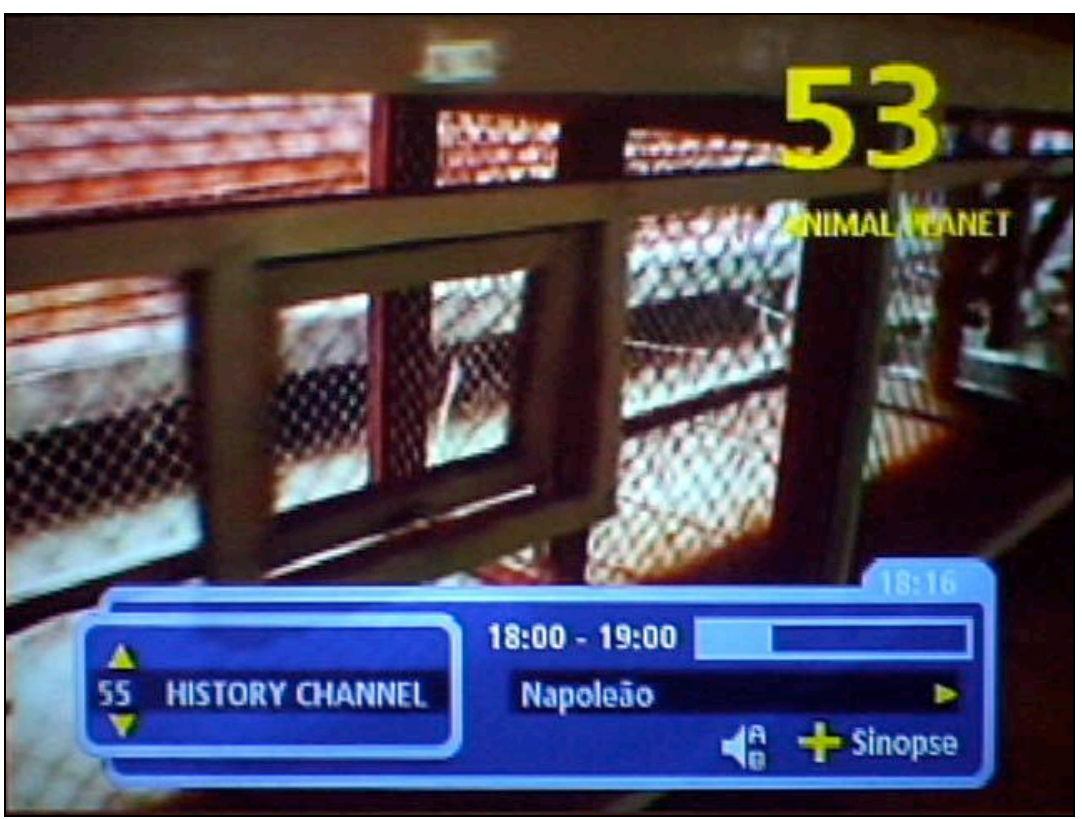

Figura 4-96 - Tarja de informações da plataforma SKY+

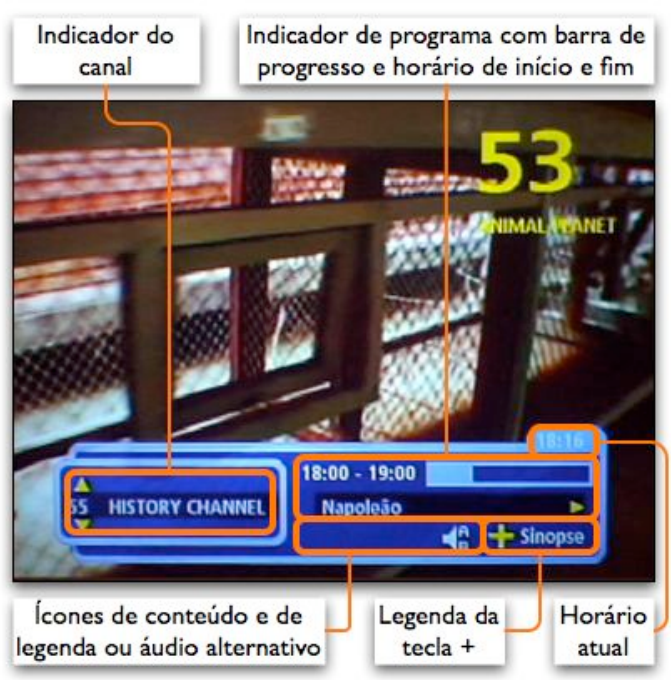

Figura 4-97 - Detalhes da tarja de informações da plataforma SKY+
A tarja de informações da plataforma SKY+ (Figura 4-96 e Figura 4-97) é muito similar à da plataforma SKY, mas ela apresenta as informações de canal e programa separadas. Um detalhe interessante é uma barra de progresso que é um indicativo visual de quanto do programa já passou. No entanto, a leitura do horário atual fica quase impossível pela ausência de contraste entre a cor da fonte e a do fundo. 


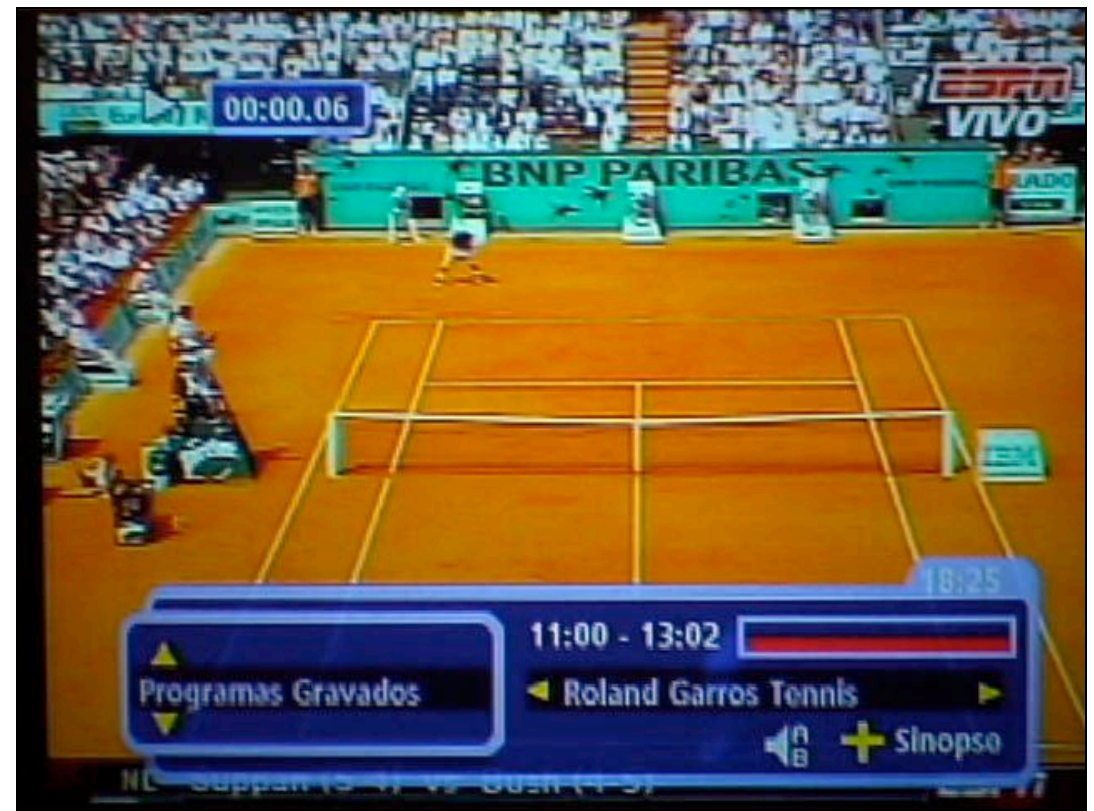

Figura 4-98 - Tarja de informações de programa gravado da plataforma SKY+

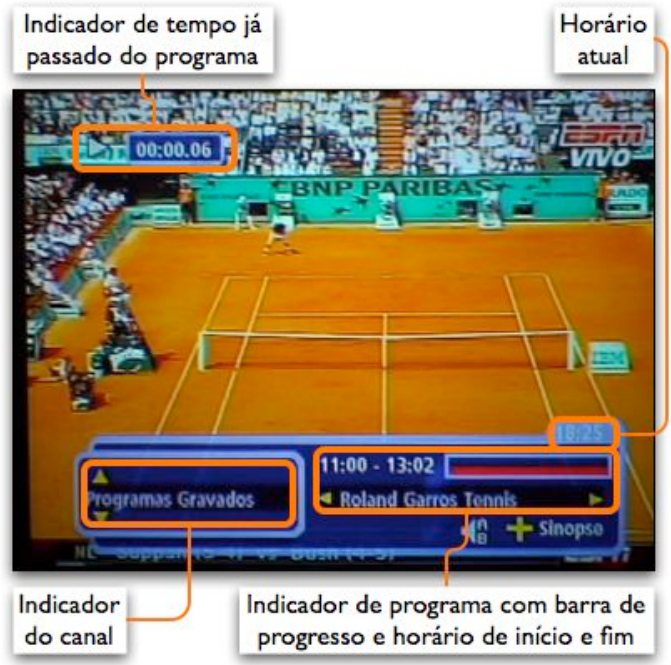

Figura 4-99 - Detalhes da tarja de informações de programa gravado da plataforma SKY+
Caso o usuário esteja assistindo um programa gravado a tarja de informações sofre algumas modificações (Figura 4-98 e Figura 4-99). A barra de progresso fica parcialmente vermelha, mostrando assim quanto do programa ainda falta para ser assistido. No canto superior esquerdo há um indicativo do tempo que já passou em horas, minutos e segundos, junto com um ícone do estado atual de reprodução (tocando, em pausa, etc.).

O indicador de canal mostra o texto “Programas Gravados" que é um “canal” virtual localizado entre o canal 185 (o último canal utilizado pelo Pay-per-view) e o primeiro canal. 


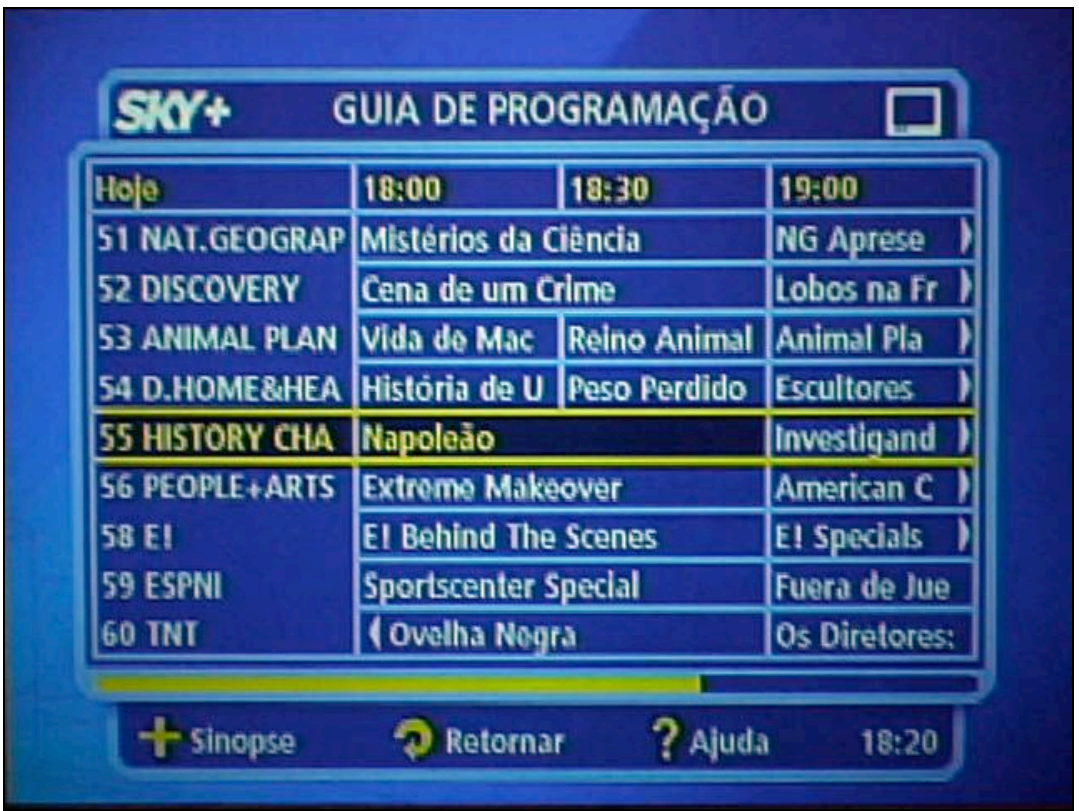

Figura 4-100 - Guia de programação da plataforma SKY+

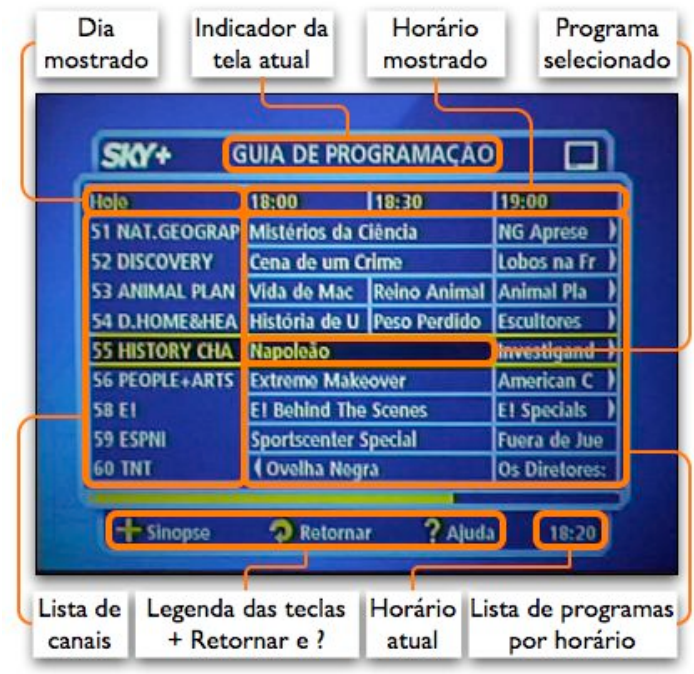

Figura 4-101 - Detalhes do guia de programação da plataforma SKY+
O guia de programação da plataforma SKY+ (Figura 4-100 e Figura 4-101) tem um arranjo bem mais compacto, com uma linha por canal. Isto permite mostrar 9 canais por tela, mas faz com que o layout fique muito carregado e os títulos dos programas mais truncados.

A barra amarela abaixo da lista de canais é um indicador do espaço em disco, mostrando quanto espaço está ocupado e quanto resta. Ao selecionar um programa para grava-

ção ele fica marcado com o símbolo de REC e a barra de espaço em disco fica com um trecho a mais em branco, até a gravação do programa. 


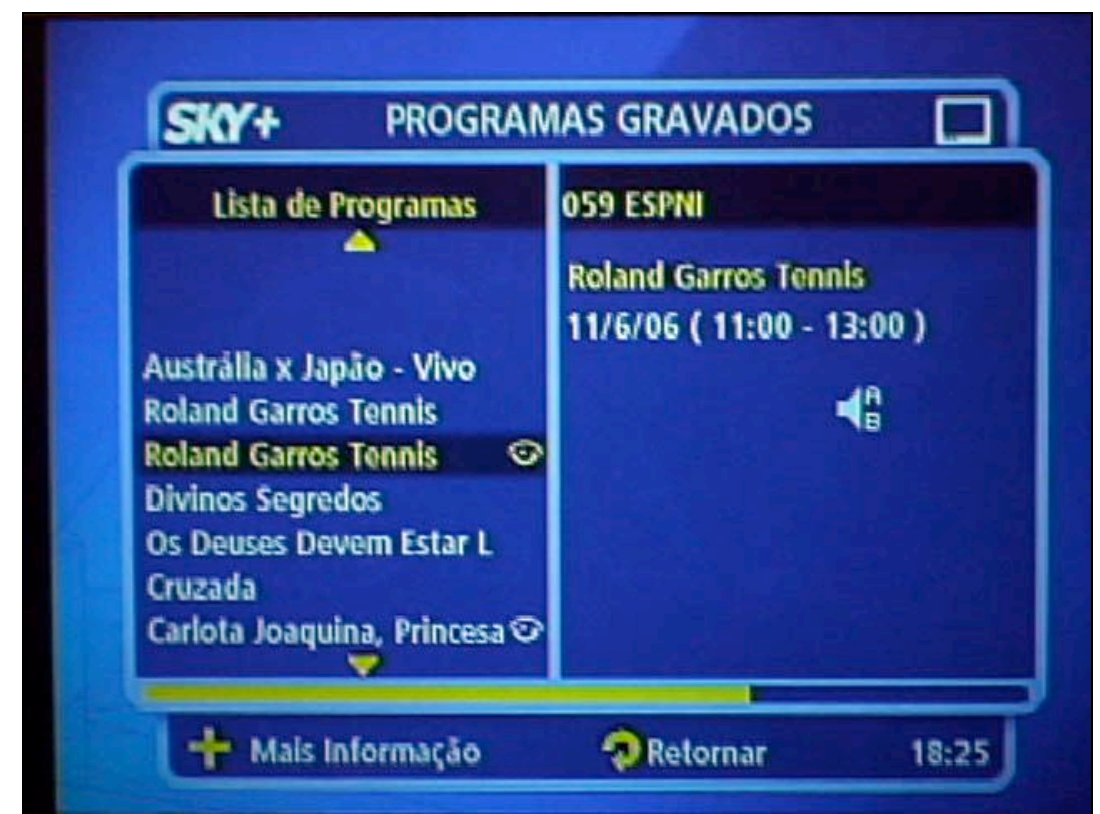

Figura 4-102 - Lista de programas gravados da plataforma SKY+

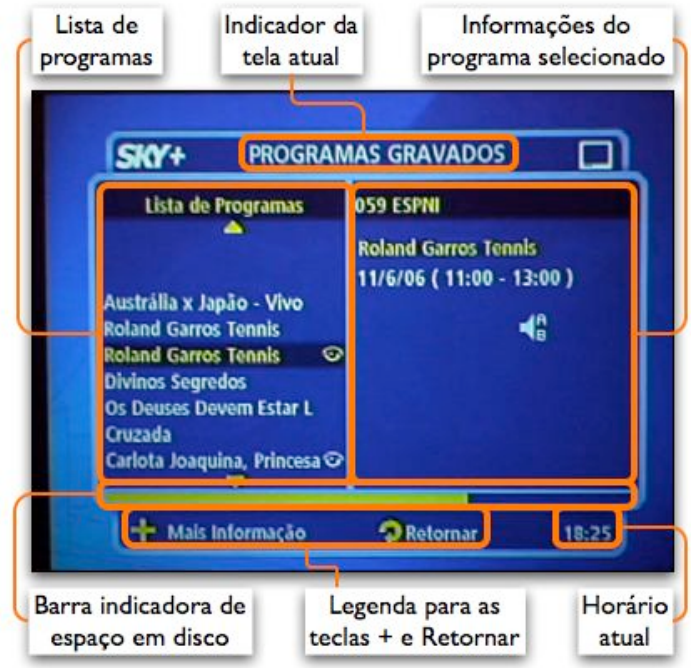

Figura 4-103 - Detalhes da lista de programas gravados da plataforma SKY+
A interface de programas gravados (Figura 4-102 Figura 4-103) permite ao usuário ver o conteúdo que tem gravado, assisti-lo e removê-lo. Ela apresenta a lista de programas à esquerda, por ordem de gravação, com os programas mais recentes no topo da lista e na parte da direita aparecem as informações sobre o programa. Um ícone no formato de um olho na lista da esquerda mar-

ca os programas que já começaram a ser assistidos.

A tecla + (com legenda Mais Informação) leva para uma tela de ajuda, que explica o funcionamento desta interface, e que poderia se chamar Ajuda. 


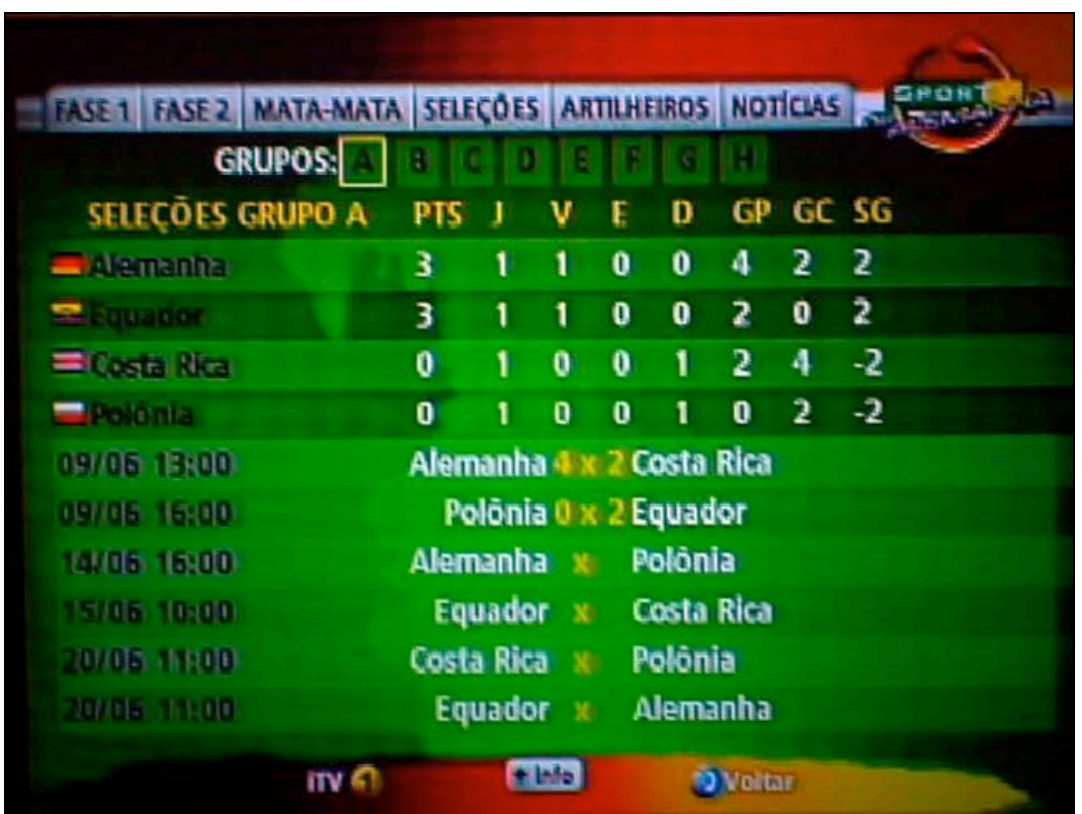

Figura 4-104 - Aplicativo com tabela de jogos de campeonato de futebol da plataforma SKY+

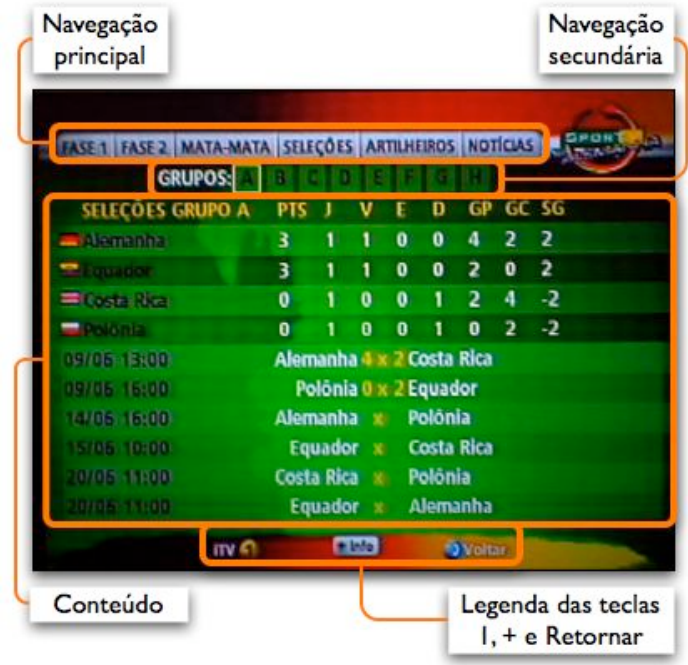

Figura 4-105 - Detalhes do aplicativo com tabela de jogos de campeonato de futebol da plataforma SKY+
Este aplicativo é o mesmo nas plataformas SKY e SKY+, mas quando esta análise foi realizada estava em andamento a Copa do Mundo e portanto a tabela de jogos era relativa a este outro campeonato.

Nesta tela (Figura 4-104 e Figura 4-105) estão os jogos da primeira fase organizados por grupos. A navegação principal fica no topo da página, onde se utiliza as setas horizontais para trocar o item sele-

cionado e a tecla de confirmação para ir para a outra tela. A navegação secundária fica abaixo da principal, e tem funcionamento igual ao da navegação principal.

A tecla 1 ou a tecla amarela levam o usuário de volta para o mosaico iTV e a tecla Voltar ou a tecla azul têm a função de voltar. 
É interessante comparar estes três aplicativos (NET Digital, SKY e SKY+) que, apesar de terem conteúdos muito semelhantes, têm telas e funcionamentos gerais bastante diferentes. Por exemplo, neste aplicativo e na tabela de jogos apresentada na plataforma anterior a tecla azul tem funcionalidades diferentes (voltar e ajuda, respectivamente). Este aplicativo foi o que levou mais tempo para carregar, 30 segundos.

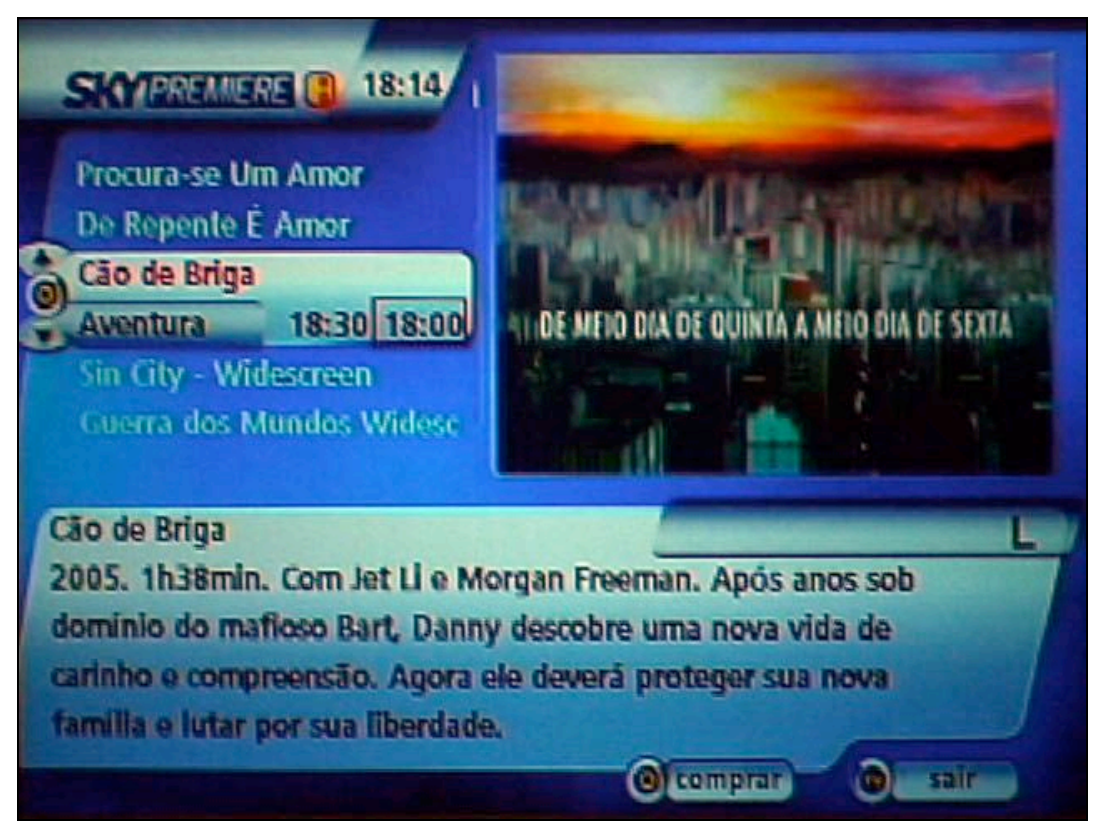

Figura 4-106 - Aplicativo de TVi da plataforma SKY+

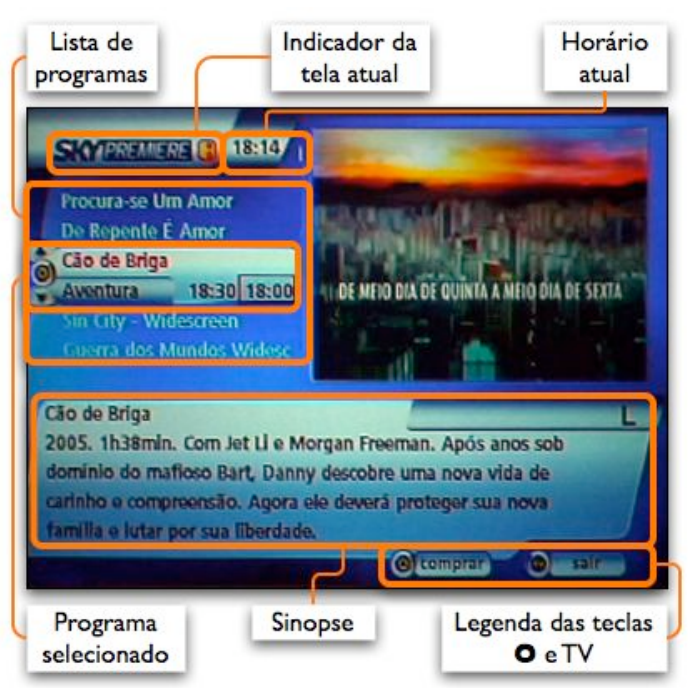

Figura 4-107 - Detalhes do aplicativo de TVi da plataforma SKY+
Este aplicativo também está presente nas duas plataformas SKY e permite comprar filmes Premiere (Pay-per-view) através do controle remoto, como um guia de programação exclusivo destes canais. Ele apresenta uma listagem de filmes com as respectivas sinopses e oferece uma interface para comprar o programa.

O interessante deste aplicativo é que ele não apresenta as teclas de navegação presentes nos outros 
aplicativos da plataforma SKY. As únicas teclas ativas são as setas verticais para selecionar os filmes, a tecla de confirmação e a tecla de TV para sair. Ele não utiliza a tecla de volta, nem as teclas coloridas, nem a tecla 1 para ir para o menu iTV.

\section{Dispositivos da Plataforma}

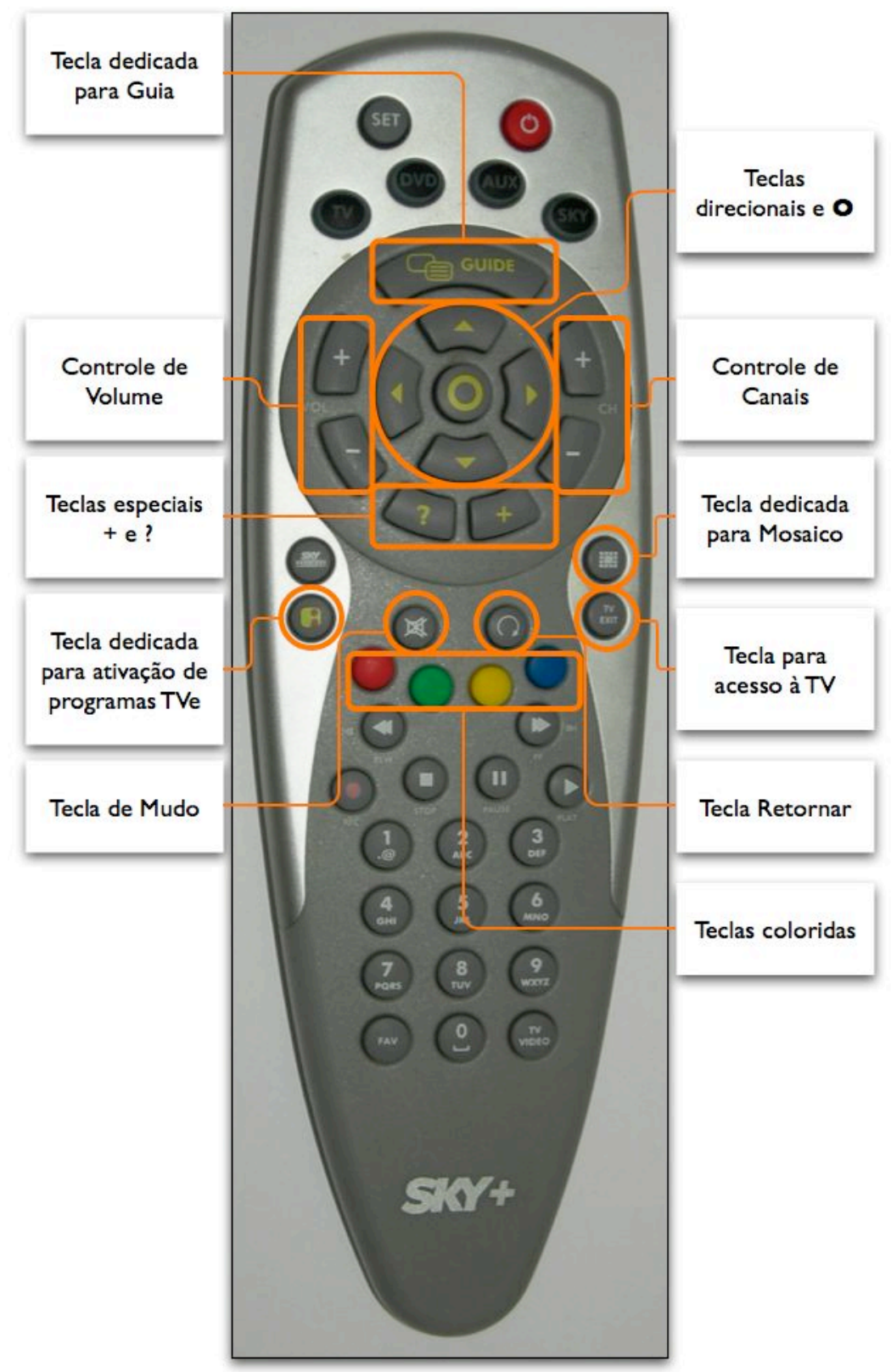

Figura 4-108 - Controle remoto da plataforma SKY+

O controle remoto da plataforma SKY+ (Figura 4-108) tem um conjunto central de teclas que concentra as teclas mais utilizadas. Na parte de cima des- 
te conjunto está a tecla para o guia de programação (Guide). Nos lados estão as teclas de controle de canal e volume e no centro estão as setas direcionais e a tecla de confirmação. Abaixo destas estão as teclas especiais ? e + (ordem inversa da plataforma SKY).

Abaixo do conjunto central à esquerda está a tecla de atalho para o mosaico Premiere (Pay-per-view) e a tecla i, para ativação de programa TVe (a tecla de confirmação também pode ser utilizada). Do lado direito estão a tecla de atalho para o mosaico principal (ícone de mosaico) e a tecla para acesso à TV (TV Exit).

No centro estão as teclas de mudo e de retorna, distantes tanto das teclas de controle de volume quanto das setas direcionais. Abaixo delas estão as teclas coloridas e, abaixo destas, seis teclas para controle de mídia, pois esta plataforma permite este tipo de funcionalidade.

O teclado numérico deste controle tem a associação entre letras e números presente em celulares. É mais parecido com o arranjo de celulares do que o aplicativo apresentado na plataforma NET Digital, pois a tecla 0 é equivalente a espaço e os símbolos (.,@) estão na tecla 1.

O posicionamento das legendas é bem melhor do que na plataforma SKY, mas tem o mesmo problema com ícones de significado próprio da plataforma e todas as legendas estão em inglês.

No total o controle tem 46 teclas.

\section{Navegação da Plataforma}

A navegação pela TV, guia de programação e portal desta plataforma é idêntica à da plataforma SKY. Apresentamos a seguir a navegação pelo aplicativo de TVi. 


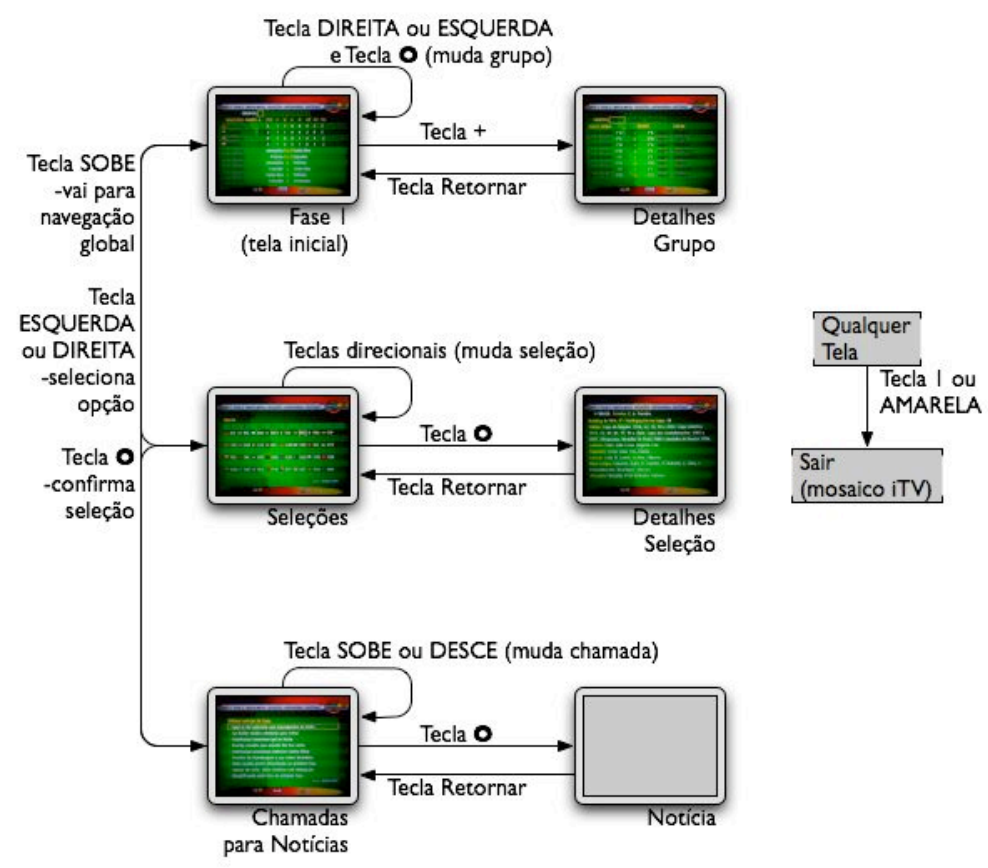

Figura 4-109 - Navegação do aplicativo com tabela de jogos de campeonato de futebol da plataforma SKY+

Este aplicativo é semelhante em estrutura de navegação ao aplicativo da plataforma NET Digital, mas ao invés de uma tela inicial para a navegação global esta é feita através de uma barra horizontal que está presente em todas as telas (Figura 4-105). Para navegar por esta barra o usuário utiliza as setas horizontais para selecionar um item e a tecla de confirmação para ir para a tela correspondente.

A navegação local varia entre as telas podendo utilizar as setas horizontais, verticais ou ambas as direções para seleção e a tecla de confirmação para mudar de tela. $\mathrm{O}$ arranjo de botões na tela serve como indicador de que direção deve ser utilizada.

A navegação global sempre está no topo da página e para acessá-la o usuário deve utilizar a tecla para cima quantas vezes forem necessárias. Para sair para a navegação local o usuário deve utilizar a seta para baixo.

Para voltar para a tela anterior o usuário pode utilizar a tecla de volta, que tem efeito contrário à tecla de confirmação. Na tela que apresenta os grupos do campeonato, porém, a navegação local é feita com a tecla $\mathbf{O}$ e os detalhes do grupo são acessados pela tecla + o que foge do resto da estrutura utilizada no aplicativo. 


\subsection{Coordenação da Interface}

\subsubsection{Mapa de Navegação}

O mapa de navegação das plataformas TVA Digital, NET Digital, SKY e SKY+ (Figura 4-38, Figura 4-53, Figura 4-73 e Figura 4-95) tem uma estrutura bastante semelhante. A principal diferença entre eles é o acréscimo de funcionalidades características de cada plataforma. Este mapa de navegação é consistente entre as plataformas e pode ser utilizado como base para um mapa de navegação genérico. No entanto, os mapas apresentam alguns problemas e diferenças em detalhes que são discutidos a seguir.

Ao ligar o aparelho na TV aberta o usuário acessa o último canal sintonizado. Uma vez que os usuários estão acostumados a este padrão ele deve ser o procedimento de referência. Nas plataformas digitais, contudo, ele só é encontrado na DirecTV. Na TVA Digital ao se ligar o aparelho aparece a tela de portal e o último canal sintonizado é mostrado em tamanho reduzido (Figura 4-43). Este enfoque permite um certo nível de continuidade com o modelo de referência, ao mesmo tempo que dá acesso a outras funcionalidades do sistema. Esta alternativa é interessante caso o usuário queira acessar outros conteúdo do sistema (aplicativos) ou queira acessar os canais de forma indireta (através do guia de programação ou através dos mosaicos).

Os mapas de navegação das plataformas SKY e SKY+ são os únicos em que, a partir do portal, é possível acessar todas as telas do sistema pela navegação na interface gráfica, ou seja, através de botões na tela. Considerando que o foco do usuário está na interface gráfica, esta forma de acesso é uma recomendação.

As plataformas TVA Digital e NET Digital são as que têm a navegação interna mais simples e clara. Como esta é uma recomendação, são as plataformas de referência neste aspecto.

Apesar das quatro plataformas terem uma estrutura semelhante, a nomenclatura que dão para as diversas partes do sistema não é consistente. $\mathrm{Na}$ Tabela 4-2 apresentamos os nomes que cada plataforma dá para as telas mais importantes do mapa de navegação. 
Tabela 4-2 - Nomes das telas principais do mapa de navegação das diversas plataformas

\begin{tabular}{|l|l|l|l|l|}
\hline & \multicolumn{1}{|c|}{ TVA } & \multicolumn{1}{c|}{ NET } & \multicolumn{1}{c|}{ SKY } & \multicolumn{1}{|c|}{ SKY+ } \\
\hline Tela Inicial & $\begin{array}{l}\text { Portal } \\
\text { TVA }\end{array}$ & Portal & Mosaico & Mosaico \\
\hline TV & (tecla Sair) & (tecla Sair) & (tecla TV) & (tecla TV Exit) \\
\hline $\begin{array}{l}\text { Guia de } \\
\text { Programação }\end{array}$ & Guia TV & Guia NET TV & $\begin{array}{l}\text { Guia de Pro- } \\
\text { gramação }\end{array}$ & $\begin{array}{l}\text { Guia de Pro- } \\
\text { gramação }\end{array}$ \\
\hline $\begin{array}{l}\text { Menu de } \\
\text { Canais de TV }\end{array}$ & $\begin{array}{l}\text { Portal (te- } \\
\text { mático) }\end{array}$ & $\begin{array}{l}\text { Mosaico (te- } \\
\text { mático) }\end{array}$ & $\begin{array}{l}\text { Mosaico (te- } \\
\text { mático) }\end{array}$ & $\begin{array}{l}\text { Mosaico (te- } \\
\text { mático) }\end{array}$ \\
\hline $\begin{array}{l}\text { Menu de aplicativos } \\
\text { de TV Ativa }\end{array}$ & -- & Interativos & Mosaico iTV & Mosaico iTV \\
\hline $\begin{array}{l}\text { Menu de } \\
\text { Configuração }\end{array}$ & Menu & Menu & Menu SKY & Menu SKY \\
\hline
\end{tabular}

A partir destas informações foi feita a proposta de nomenclatura que apresentamos na Tabela 4-3.

Tabela 4-3 - Proposta de nomes para as telas principais do mapa de navegação

\begin{tabular}{|l|l|l|}
\hline & \multicolumn{1}{|c|}{$\begin{array}{c}\text { Nome } \\
\text { Proposto }\end{array}$} & \multicolumn{1}{c|}{ Descrição } \\
\hline Tela Inicial & Portal & Tela por onde toda a navegação tem início \\
\hline TV & TV & São os canais de TV \\
\hline $\begin{array}{l}\text { Guia de Programa- } \\
\text { ção }\end{array}$ & $\begin{array}{l}\text { Guia de Pro- } \\
\text { gramação }\end{array}$ & $\begin{array}{l}\text { Tela que apresenta a programação nos diver- } \\
\text { sos canais e horários }\end{array}$ \\
\hline $\begin{array}{l}\text { Menu de Canais de } \\
\text { TV }\end{array}$ & Mosaico & $\begin{array}{l}\text { Tela de menu que mostra os canais disponí- } \\
\text { veis, provavelmente agrupados por tema }\end{array}$ \\
\hline $\begin{array}{l}\text { Menu de aplicativos } \\
\text { de TV Ativa }\end{array}$ & $\begin{array}{l}\text { Menu de TV } \\
\text { Ativa }\end{array}$ & $\begin{array}{l}\text { Tela de menu que mostra os aplicativos dis- } \\
\text { poníveis }\end{array}$ \\
\hline $\begin{array}{l}\text { Menu de Configu- } \\
\text { ração }\end{array}$ & $\begin{array}{l}\text { Menu de Con- } \\
\text { figuração }\end{array}$ & $\begin{array}{l}\text { Tela de menu que dá acesso às configurações } \\
\text { do sistema }\end{array}$ \\
\hline
\end{tabular}

Desta forma o mapa de navegação genérico de uma plataforma de TV interativa é apresentado na Figura 4-110. 


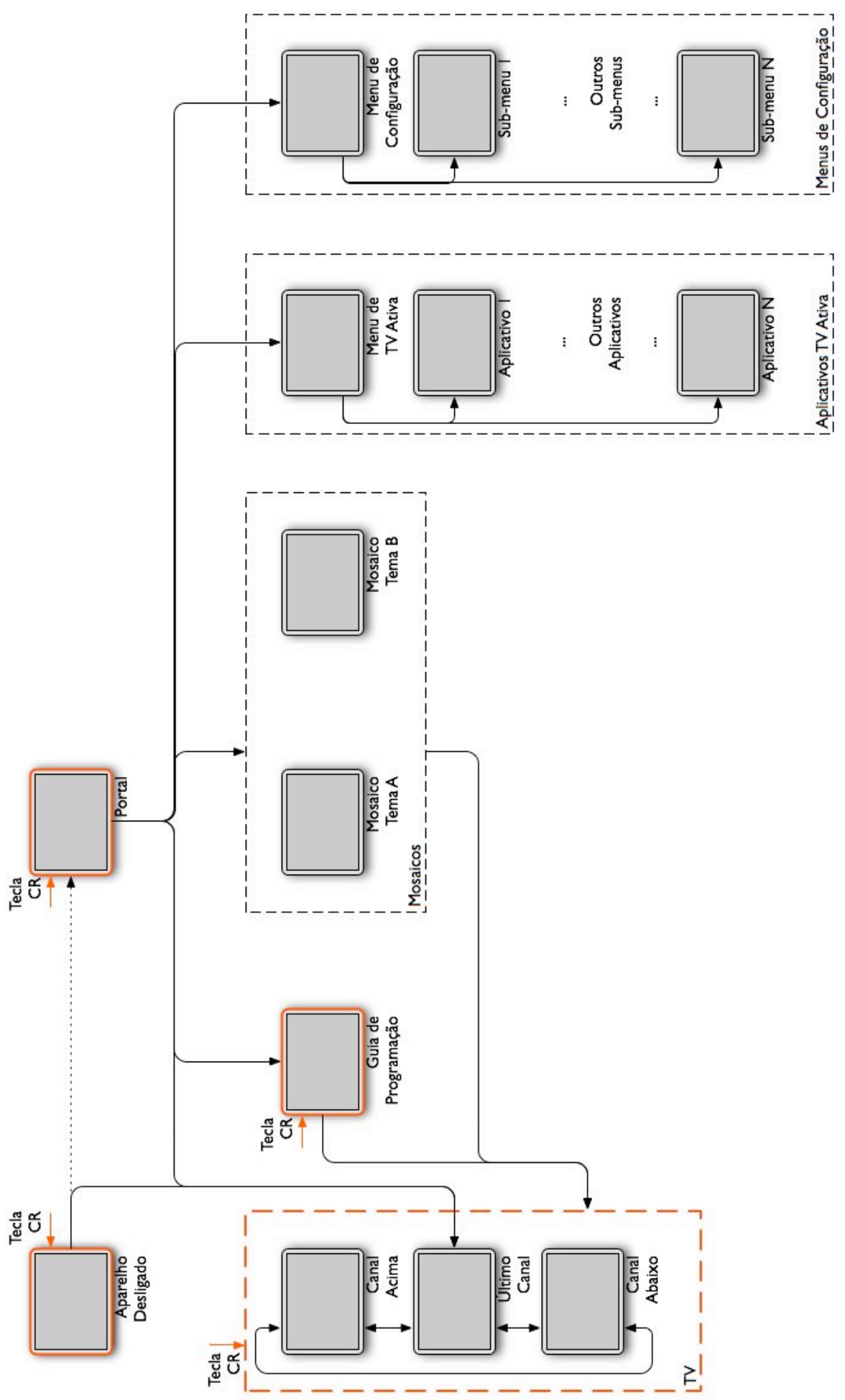

Figura 4-110 - Mapa de navegação proposto 


\subsubsection{Telas}

A principal recomendação para o design de telas é que estas sejam feitas em conjunto com o dispositivo de interação, no caso o controle remoto. A melhor forma de realizar esta integração é através de um conjunto mínimo de teclas no controle remoto, que será apresentado no item seguinte, e a utilização de botões na interface gráfica para funções específicas do contexto onde o usuário se encontra. Este enfoque tem suas bases nas evidências encontradas nas diretrizes gerais de interface, que indicam uma preferência pelo uso de elementos de tela (botões na interface gráfica) ao invés de teclas dedicadas no controle remoto e também que a alternância de foco entre a tela da TV e o controle remoto deve ser evitada.

Neste enfoque é necessário ocupar parte da tela com botões, o que gera um conflito, visto que a tela tem um espaço limitado e também é utilizada para apresentar o conteúdo. Deve-se então considerar a quantidade de espaço disponível na tela e a quantidade de botões necessários, que tem relação com a complexidade do aplicativo. Nos parágrafos seguintes abordamos algumas soluções para três casos típicos, menus de navegação, TV e aplicativos de TV ativa.

No caso dos menus de navegação (e telas de portal) normalmente existem muitos botões. No entanto, são telas cujo objetivo principal é justamente facilitar a navegação, e portanto dispõem de muito espaço na tela para este fim. Exemplos desta aplicação são a tela de portal da TVA Digital (Figura 4-43) e os mosaicos temáticos da plataforma SKY (Figura 4-80). No primeiro exemplo o canal sintonizado fica reduzido no canto superior direito da tela e o resto da tela é ocupado por doze botões. No segundo exemplo a tela inteira é ocupada por botões, podendo ter até vinte e cinco botões.

O caso dos canais de TV apresenta a situação inversa. A quantidade de botões é reduzida mas não existe nenhum espaço disponível para eles, visto que a tela é completamente preenchida pelo conteúdo de vídeo apresentado. As duas soluções mais comuns neste caso são sobreposição de conteúdo ou redução do vídeo (LAMONT, 2003). 
O exemplo mais comum de sobreposição de conteúdo é a tarja de informações encontrada em todas as plataformas digitais (Figura 4-27, Figura 4-39, Figura 4-54, Figura 4-74 e Figura 4-96). Este enfoque também é possível para aplicativos de TVe, como no caso do canal Fox News na plataforma SKY (Figura 4-111).

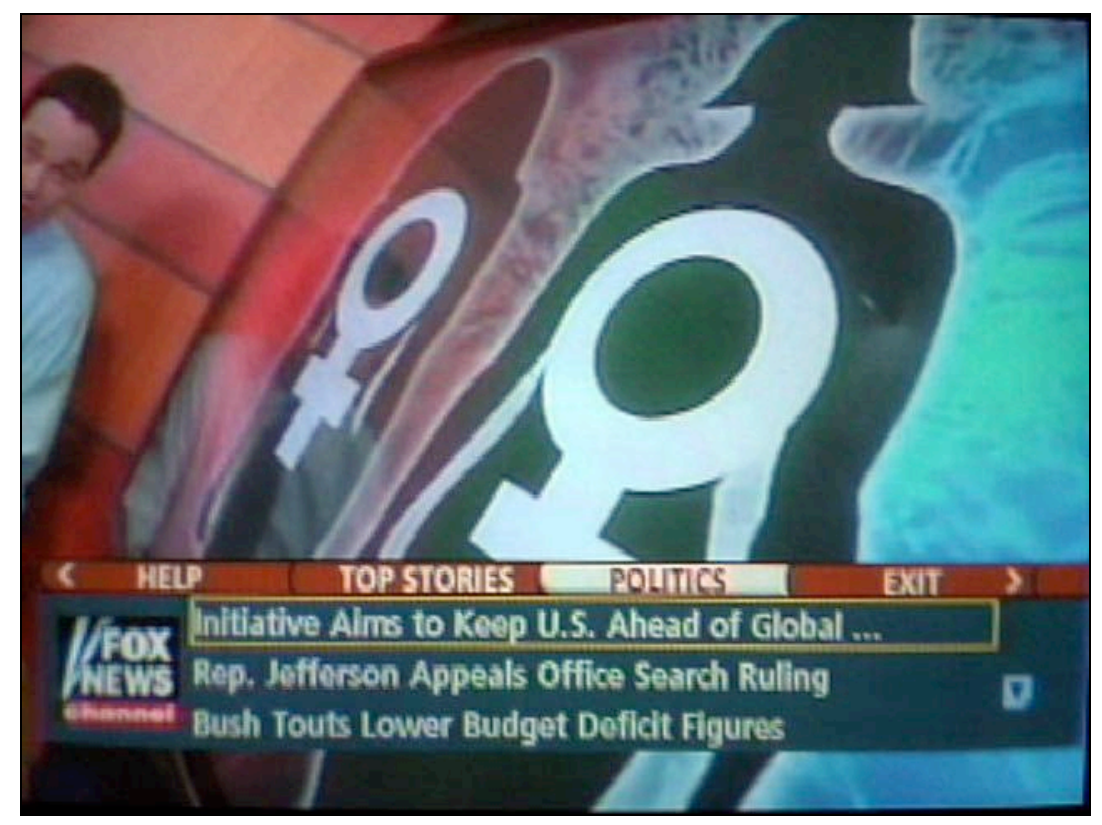

Figura 4-111 - Uso de tarja sobreposta ao programa de TVe do canal Fox News

A solução de redução do vídeo pode ser vista no canal Globo News, também na plataforma SKY (Figura 4-88). Uma variação comum desta solução para programas com multiprogramação (o usuário pode escolher entre alguns fluxos audiovisuais alternativos) é subdividir o espaço do vídeo em quatro partes e o usuário pode escolher qual fluxo audiovisual quer acompanhar. Este tipo de utilização não foi encontrado nas plataformas analisadas, e a Figura 4-112 apresenta um exemplo desta aplicação no programa de TVe no canal Disney da plataforma SKY no Reino Unido. 


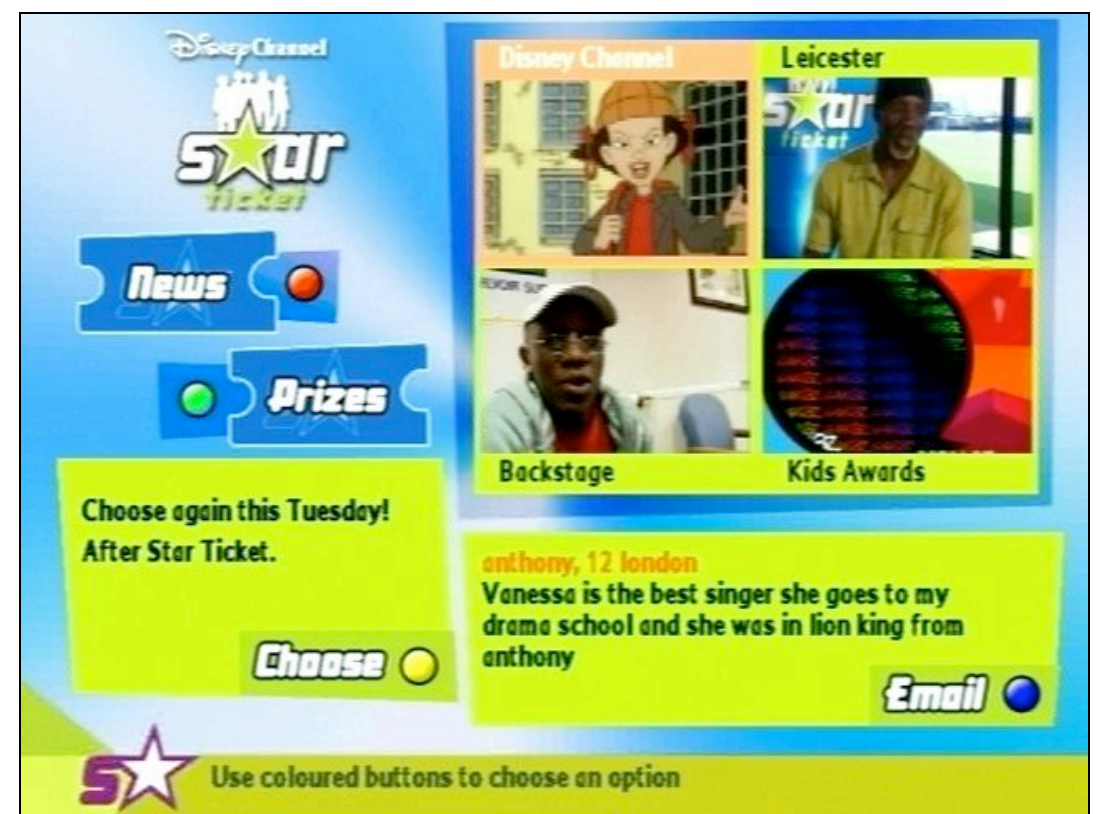

Figura 4-112 - Uso de vídeo reduzido dividido em quatro no programa de TVe do canal Disney (BROADBAND, 2006)

O principal fator para a escolha entre o enfoque de conteúdo sobreposto ou de vídeo reduzido está relacionado à importância relativa entre o conteúdo audiovisual e o conteúdo adicional a ser apresentado. De maneira geral o conteúdo sobreposto dá maior ênfase ao conteúdo audiovisual, enquanto o inverso ocorre no enfoque de vídeo reduzido (LAMONT, 2003).

Conforme citado anteriormente, a escolha também depende do espaço necessário para apresentar os botões na tela e o espaço que pode ser ocupado por eles, mas este não é o fator predominante. Para resolver o conflito entre um espaço reduzido com uma grande quantidade de botões foi observada a mesma solução em um programa da emissora inglesa BBC e no Guia de Estilo da instituição finlandesa Arvid (ARVID, 2004).

Esta solução (Figura 4-113 e Figura 4-114) utiliza o paradigma da barra de menus de desdobrar que no computador está presente no topo das telas e que neste caso é aplicado na parte inferior da tela, fazendo com que os menus se desdobrem para cima. 


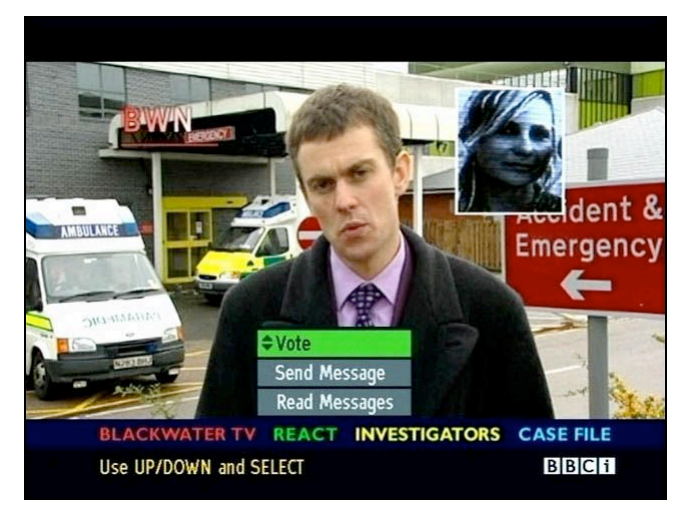

Figura 4-113 - Menu de desdobrar em programa da emissora BBC (BROADBAND, 2006)

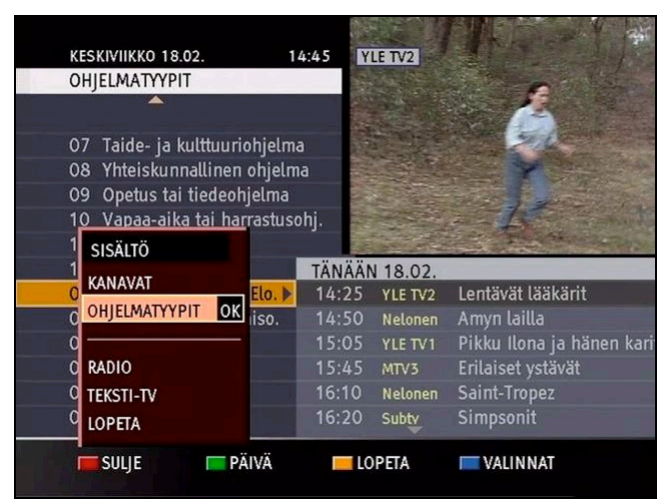

Figura 4-114 - Menu de desdobrar no Guia de Estilo da Arvid (ARVID, 2004)

Um problema nos dois exemplos encontrados é que ambos utilizam as teclas coloridas para a ativação dos menus, o que faz com que o usuário tenha que alternar seu foco de atenção entre a tela e o controle remoto e portanto não estão de acordo as recomendações. Desta forma, o que deve ser observado nestes exemplos é o mecanismo de abrir um menu para mostrar as opções disponíveis no contexto, mas sua ativação deve ser resolvida de uma maneira mais integrada com o controle remoto.

O terceiro caso abordado é o de aplicativos de TV ativa. Neste caso a tanto a quantidade de espaço disponível quanto a de botões necessários é variável, e as telas devem ser concebidas levando ambos em consideração. De maneira geral procura-se ocupar o máximo do espaço central da tela com o conteúdo, ficando os botões na região periférica da tela (Figura 4-64, Figura 4-86 e Figura 4-104). Caso haja um conflito entre um espaço reduzido disponível e uma grande quantidade de botões uma solução seria adotar um menu com botões sobreposto ao conteúdo. Esta solução não foi encontrada nos aplicativos analisados e a Figura 4-115 apresenta uma simulação desta alternativa feita sobre o aplicativo da NET Digital (Figura 4-64). 


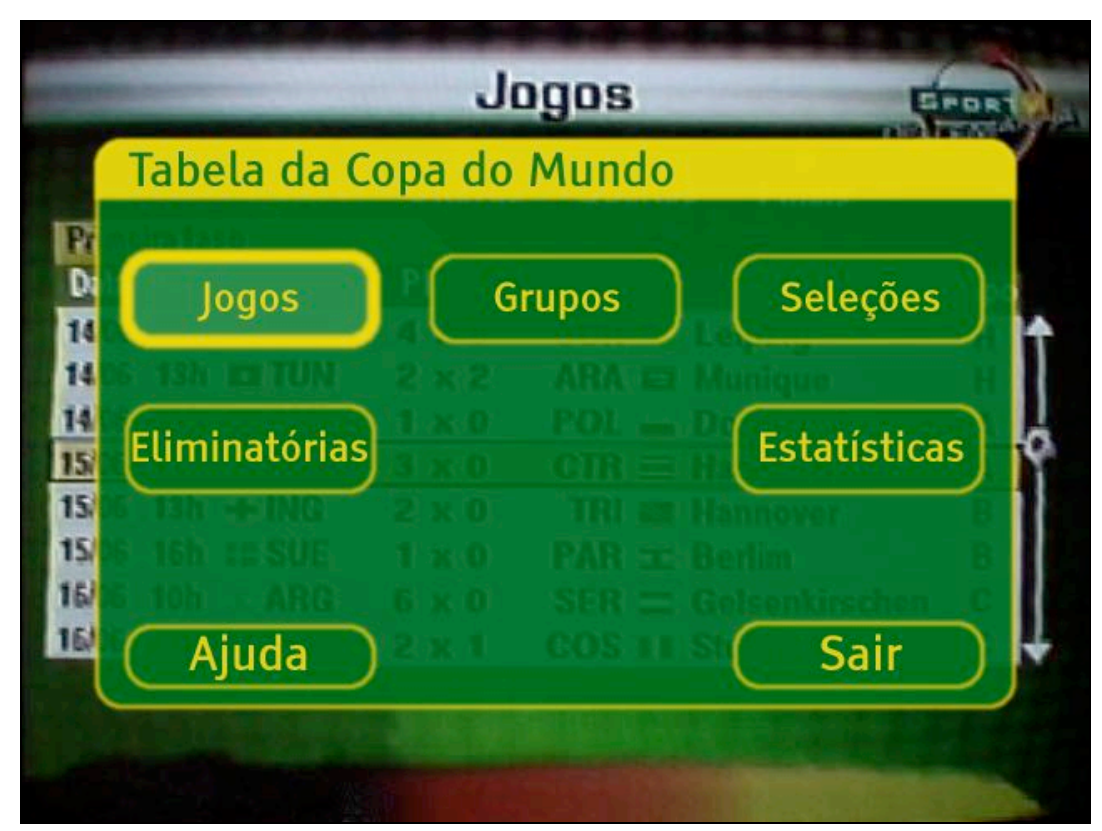

Figura 4-115 - Simulação de menu de opções sobre aplicativo de TV ativa

A fim de reforçar a integração entre interface gráfica e o controle remoto, os botões da interface gráfica devem estar organizados em uma grade ortogonal. Este arranjo é o mais adequado para a utilização em conjunto com as setas direcionais do controle remoto e é bastante utilizado, podendo ser visto tanto no portal da TVA Digital (Figura 4-43) quanto no portal da SKY (Figura 4-78). O portal da plataforma NET Digital (Figura 4-58) apresenta um problema neste sentido, pois tem uma coluna de botões à esquerda, mas os dois elementos superiores (Guia NET TV e Ajuda) estão fora deste alinhamento.

\subsubsection{Controle Remoto}

Conforme citado no item anterior, é necessária uma integração entre o controle remoto e a interface gráfica. Para que esta integração aconteça é necessário que haja um conjunto mínimo de teclas presentes no controle remoto. Na Tabela 4-4 apresentamos uma análise das teclas utilizadas em cada plataforma de acordo com sua funcionalidade. A tabela está dividida em três grupos (branco, cinza e azul), que serão explicados a seguir. 
Tabela 4-4 - Nomes das teclas do controle remoto em função de sua funcionalidade e plataforma

\begin{tabular}{|c|c|c|c|c|c|c|c|}
\hline & $\begin{array}{c}\text { TV } \\
\text { Aberta }\end{array}$ & $\begin{array}{l}\text { Cabo } \\
\text { Analóg. }\end{array}$ & DirecTV & TVA & NET & SKY & SKY+ \\
\hline Liga & $\begin{array}{l}\text { Liga/ } \\
\text { Desl. }\end{array}$ & Power & On/Off & Ícone & Ícone & Ícone & Ícone \\
\hline $\begin{array}{l}\text { Controle } \\
\text { Canal }\end{array}$ & $\mathrm{Ch}+/-$ & $\begin{array}{l}\text { Ch (se- } \\
\text { tas) }\end{array}$ & $\begin{array}{l}\text { Ch (se- } \\
\text { tas) }\end{array}$ & $\begin{array}{l}\text { Canal } \\
+/-\end{array}$ & $\mathrm{Ch}+/-$ & (setas) & $\mathrm{Ch}+/-$ \\
\hline $\begin{array}{l}\text { Último Ca- } \\
\text { nal }\end{array}$ & $\begin{array}{l}\text { Last } \\
\mathrm{Ch}\end{array}$ & Ícone & Go Back & Último & Voltar & $\begin{array}{l}\text { Ícone (Re- } \\
\text { torna) }\end{array}$ & $\begin{array}{l}\text { Ícone (Re- } \\
\text { torna) }\end{array}$ \\
\hline $\begin{array}{l}\text { Controle } \mathrm{Vo}^{-} \\
\text {lume }\end{array}$ & $\begin{array}{l}\text { Vol } \\
+/-\end{array}$ & $\begin{array}{l}\text { Vol (se- } \\
\text { tas) }\end{array}$ & $\begin{array}{l}\text { Vol (se- } \\
\text { tas) }\end{array}$ & $\begin{array}{l}\text { Volume } \\
+/-\end{array}$ & $\begin{array}{l}\text { Ícone } \\
+/-\end{array}$ & $\begin{array}{l}\text { Ícone (se- } \\
\text { tas) }\end{array}$ & Vol +/- \\
\hline Mudo & Mudo & Mute & Mute & Ícone & Ícone & Ícone & Ícone \\
\hline $\begin{array}{l}\text { Teclado } \\
\text { Numérico }\end{array}$ & Sim & Sim & Sim & Sim & Sim & Sim & Sim \\
\hline $\begin{array}{l}\text { Setas Dire- } \\
\text { cionais }\end{array}$ & Não & Não & Sim & Sim & Sim & Sim & Sim \\
\hline Confirmação & Não & Não & SEL/OK & SEL & OK & Ícone & Ícone \\
\hline Volta & Não & Não & Go Back & Não & Voltar & $\begin{array}{l}\text { Ícone (Re- } \\
\text { torna) }\end{array}$ & $\begin{array}{l}\text { Ícone (Re- } \\
\text { torna) }\end{array}$ \\
\hline $\begin{array}{l}\text { Guia de } \\
\text { Programa- } \\
\text { ção }\end{array}$ & -- & -- & Guide & Guia TV & $\begin{array}{l}\text { NET } \\
\text { TV }\end{array}$ & G & Guide \\
\hline TV & -- & -- & Clear & Sair & Sair & TV & TV Exit \\
\hline Portal & -- & -- & -- & $\begin{array}{l}\text { Portal } \\
\text { TVA }\end{array}$ & Portal & $\begin{array}{l}\text { Ícone } \\
\text { (Mosaico) }\end{array}$ & $\begin{array}{l}\text { Ícone } \\
\text { (Mosaico) }\end{array}$ \\
\hline Ajuda & -- & -- & -- & Ajuda & Ajuda & Não & Não \\
\hline $\begin{array}{l}\text { Tarja de In- } \\
\text { formações } \\
\text { (TV) }\end{array}$ & -- & -- & Info & $\begin{array}{l}\text { Setas } \\
\text { Direcion. }\end{array}$ & Info & $?$ & ? \\
\hline $\begin{array}{l}\text { Opções de } \\
\text { Áudio e Le- } \\
\text { genda (TV) }\end{array}$ & -- & -- & $\begin{array}{l}\text { Alt Au- } \\
\text { dio e } \\
\text { Subtitles }\end{array}$ & Opções & Opções & + & + \\
\hline $\begin{array}{l}\text { Número de } \\
\text { Teclas }\end{array}$ & 26 & 28 & 46 & 35 & 39 & 32 & 46 \\
\hline
\end{tabular}


O primeiro grupo (branco) é formado por teclas que estão presentes em todos os controles analisados. Estas teclas representam a tecla de liga e desliga, os controle básicos da televisão e o teclado numérico. Além de ser um grupo universalmente disponível, representam tarefas muito importantes no sistema, conforme observado na análise de tarefas, e portanto devem fazer parte do conjunto mínimo de teclas.

Neste conjunto existem duas ressalvas a serem feitas. A funcionalidade de Último Canal (alterna entre os dois últimos canais sintonizados) nas plataformas digitais é feita pela tecla Volta. Este uso não deve ser feito pois interfere com a função original da tecla Volta e cria uma inconsistência no modelo de navegação. A função de Último Canal deve ter uma tecla própria. A segunda ressalva é que como na TVi existe a possibilidade de digitação de textos curtos pelo controle remoto (Figura 4-66) o teclado numérico deve ter letras associadas às suas teclas, de forma semelhante ao telefone celular, seguindo a norma ITU-T E.161. O único controle que segue este diretriz é o da plataforma SKY+ (Figura 4-108).

O segundo grupo (cinza) é composto de teclas que estão em praticamente todas as plataformas digitais. As únicas exceções são a tecla Volta, que não está presente na plataforma TVA Digital, a tecla Portal, que não está presente na plataforma DirecTV (esta plataforma não tem a tela correspondente ao portal) e a tecla Ajuda, que não está presente nas plataformas DirecTV, SKY e SKY+.

As setas direcionais e a tecla de confirmação, além de estarem em todas as plataformas digitais, são fundamentais para o modelo de navegação pela interface gráfica e portanto sua presença é essencial no controle remoto. A tecla Volta também é fundamental para o modelo de navegação e há uma recomendação específica para que exista uma tecla com esta funcionalidade, e portanto também deve fazer parte do conjunto mínimo de teclas. As teclas do Guia de Programação, TV e Portal são atalhos para telas importantes, conforme apresentado no mapa de navegação, e devido à freqüência de uso também devem estar no conjunto mínimo, sendo que a tecla Portal também é objeto de uma recomendação específica. A tecla Ajuda é um atalho para a funcionalidade de ajuda, que é muito importante para usuários que não estejam familia- 
rizados com tecnologias digitais. Além disso, o usuário pode precisar de ajuda até para acessar a ajuda pela interface gráfica, e portanto é necessária uma tecla para esta funcionalidade.

O terceiro grupo (azul) indica as teclas utilizadas para duas funções específicas do contexto de TV, a ativação da tarja de informações e o acesso às opções de legenda e áudio alternativo.

Neste grupo são utilizadas algumas teclas dedicadas (Info, Opções, ? e +) para ativar estas duas funcionalidades. Nas plataformas DirecTV, TVA Digital e NET Digital as teclas utilizadas (Info e Opções) não têm função em outros contextos e não trabalham em conjunto com o modelo de navegação geral da plataforma, baseado nas setas direcionais e tecla de confirmação. No caso das plataformas SKY e SKY + as teclas ? e + têm o funcionamento de teclas contextuais (soft keys), isto é, adquirem funções específicas de acordo com o contexto. Nas situações de uso mais comuns o usuário se habitua à funcionalidade de cada uma das teclas e as utiliza de forma adequada, mas sempre é necessário apresentar na tela qual a funcionalidade da tecla naquele contexto e, em contextos onde o usuário não está habituado, é necessário associar a tecla à funcionalidade descrita na tela. Além disto, no contexto de TV estas teclas a princípio não têm legenda (a tela está ocupada pelo vídeo) e portanto o usuário não sabe qual seu efeito antes de acioná-las.

As funcionalidades ativadas por estas teclas são necessárias, mas os mecanismos que encontramos para ativá-las não são adequados. A proposta que é feita neste caso é a utilização de uma tecla denominada Opções, que mostra na tela as opções disponíveis no contexto atual do usuário; desta forma o usuário não precisa tirar o foco de atenção da tela e independentemente da situação utiliza sempre a mesma tecla, que tem uma função única e definida. Este mecanismo faz parte do modelo de navegação proposto, que será abordado em detalhe no item seguinte.

Desta forma o conjunto mínimo de teclas proposto contém as 28 teclas seguintes:

- Liga/Desliga: liga e desliga o terminal de acesso;

- Volume mais e menos: aumenta e diminui volume;

- Mudo: ativa e desativa a função de mudo; 
- Canal mais e menos: vai para o próximo canal e para o canal anterior;

- Último canal: vai para o último canal sintonizado;

- Teclado numérico: 10 teclas com os números de 0 a 9, seguindo a norma ITU-T E.161 para associação entre letras e teclas numéricas;

- Setas direcionais: 4 teclas nas direções direita, esquerda, para cima e para baixo;

- OK: tecla que confirma seleção feita com as setas direcionais;

- Volta: desfaz a ação feita pela tecla de confirmação;

- Guia: tecla de atalho para o guia de programação;

- TV: tecla de atalho para o canal sintonizado em tela inteira;

- Portal: tecla de atalho para o portal;

- Ajuda: tecla de atalho para a funcionalidade de ajuda e

- Opções: mostra as opções disponíveis no contexto atual do usuário.

Também é uma recomendação que as teclas estejam agrupadas no controle remoto por grupos funcionais e que estes estejam claramente separados entre si. Os grupos funcionais propostos são os seguintes:

- Liga e desliga (1 tecla)

- Controles de TV: aumenta volume, diminui volume, mudo, próximo canal, canal anterior, último canal (6 teclas)

- Teclado numérico: números de 0 a 9 (10 teclas)

- Navegação: quatro setas direcionais, volta e opções (7 teclas)

- Teclas de atalho: portal, guia de programação, TV e ajuda (4 teclas) 
Baseados nestas informações a Figura 4-116 apresenta um esquema de controle que está de acordo com as teclas e os grupos propostos neste trabalho.

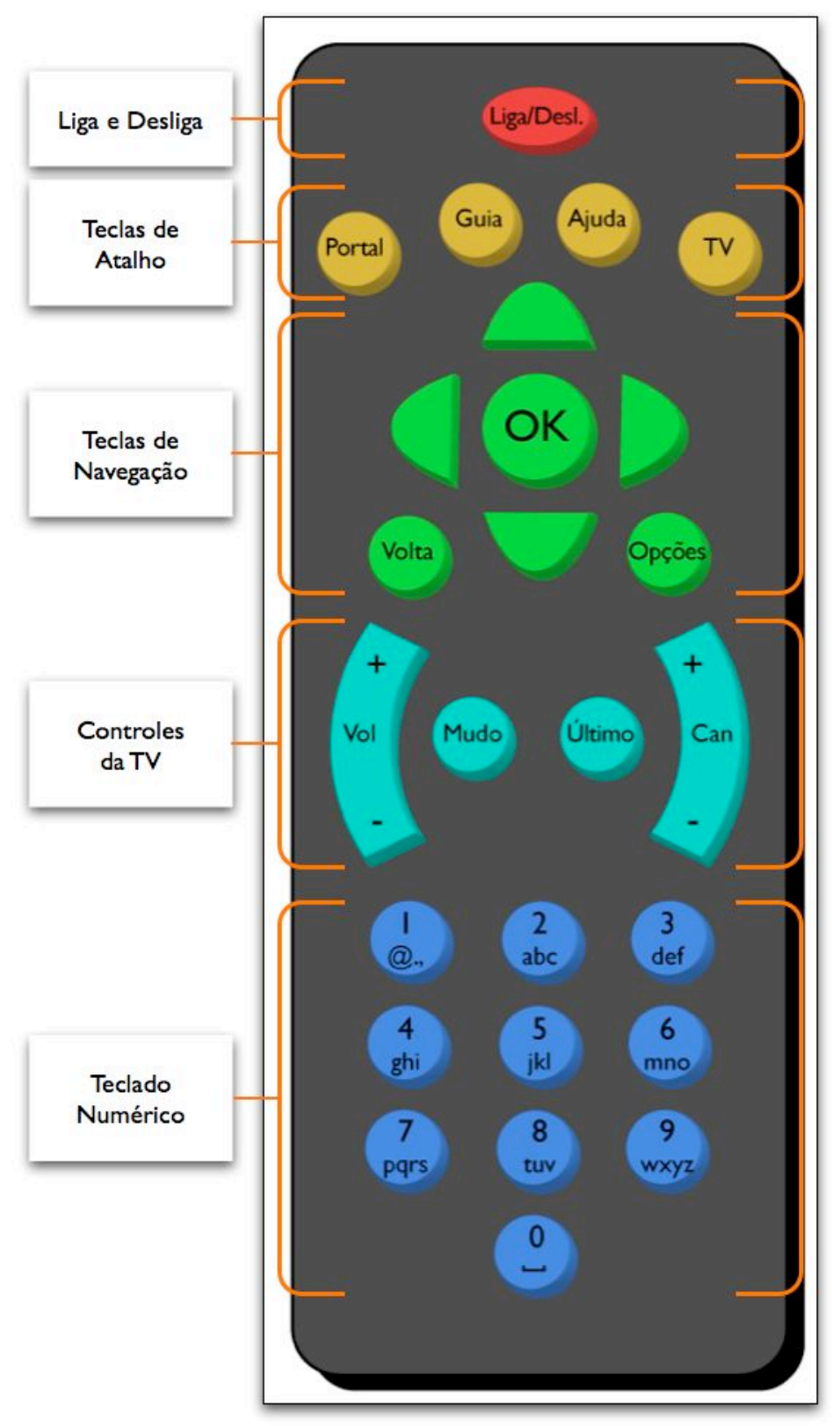

Figura 4-116 - Esquema de controle remoto com teclas e grupos propostos

\subsubsection{Modelo de Navegação}

As plataformas analisadas apresentam no mínimo dois modelos de navegação distintos. Um modelo mais amplamente utilizado (exemplo: Figura 
4-71) baseado nas setas direcionais, tecla de confirmação e volta e outro modelo específico para o contexto de TV (exemplo: Figura 4-91) onde as setas direcionais e a tecla de confirmação têm função semelhante, mas a tecla Volta serve para alternar entre dois canais e algumas funcionalidades específicas são realizadas somente através de teclas dedicadas. A coexistência destes dois modelos de navegação cria inconsistências na interface da plataforma e piora sua usabilidade.

Além disto, embora os modelos utilizados sejam suficientes para realizar as ações principais de um contexto, eles são pouco extensíveis e as ações secundárias são feitas através de soluções pontuais e não generalizáveis. Um exemplo disto está na tarja de informação, onde a navegação por canais e horário é sempre feita pelas teclas direcionais; no entanto, a ativação da sinopse é feita de forma distinta nas diversas plataformas (e mesmo dentro da mesma plataforma, mas quando acessada pelo guia de programação). A falta de um modelo geral de navegação também afeta os aplicativos de TV ativa, pois cada aplicativo é obrigado a desenvolver suas próprias soluções. Desta forma, cada aplicativo pode apresentar variações sobre os modelos de navegação da plataforma, aumentando a inconsistência geral do sistema.

Considerando estes fatores, percebemos a necessidade de um modelo único, consistente e extensível para ser utilizado em aplicativos de TVi. O ponto de partida tomado foi o sistema geral de setas direcionais, tecla de confirmação e de voltar. A este modelo foram associadas as soluções já comentadas anteriormente: apresentar botões na interface gráfica ao invés de utilizar teclas dedicadas no controle remoto e a existência de uma tecla específica no controle remoto para mostrar ao usuário as opções disponíveis no contexto onde se encontra.

Neste sistema as setas direcionais servem para selecionar um item, a tecla de confirmação realiza a ação mais comum no item selecionado e a tecla de voltar reverte a ação feita pela tecla de confirmação. A tecla de opção mostra na tela todas as opções disponíveis para o item selecionado, que podem ser escolhidas pelas setas direcionais e a tecla de confirmação. Este modelo está baseado no paradigma WIMP (Windows, Icons, Menus and Pointer), que é amplamente utilizado em computadores pessoais. No paradigma WIMP o clique do mouse seleciona o item e o duplo clique realiza a tarefa mais comum. 
do mouse seleciona o item e o duplo clique realiza a tarefa mais comum. As outras opções disponíveis para o item selecionado podem ser vistas com um clique no botão direito do mouse (que mostra um menu contextual) ou através da barra de menus no topo da tela.

A partir do modelo de navegação proposto foram elaborados os quatro fluxos de navegação possíveis para as mesmas situações analisadas nas plataformas, apresentados nas figuras a seguir.

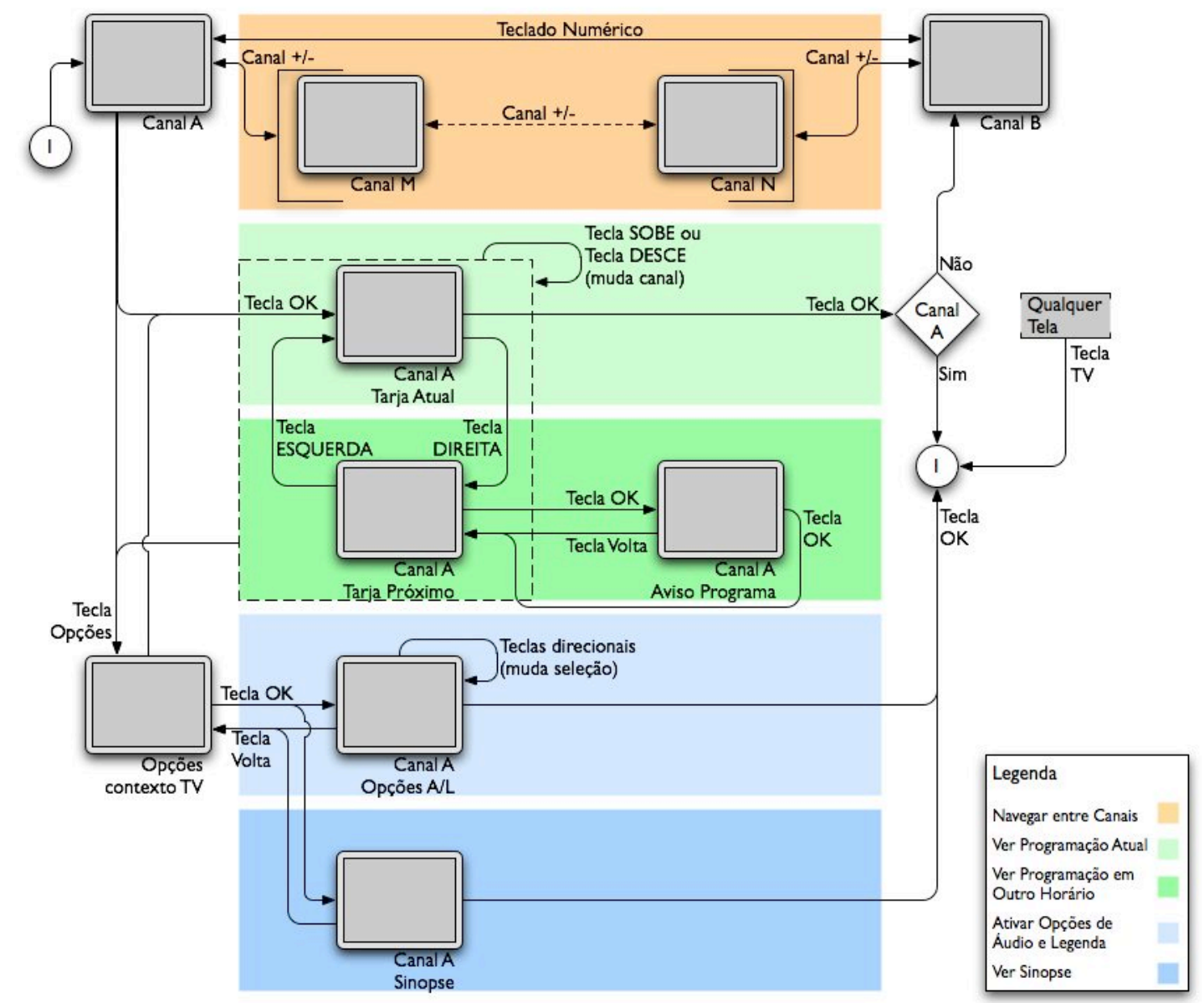

Figura 4-117 - Navegação de TV no modelo proposto 


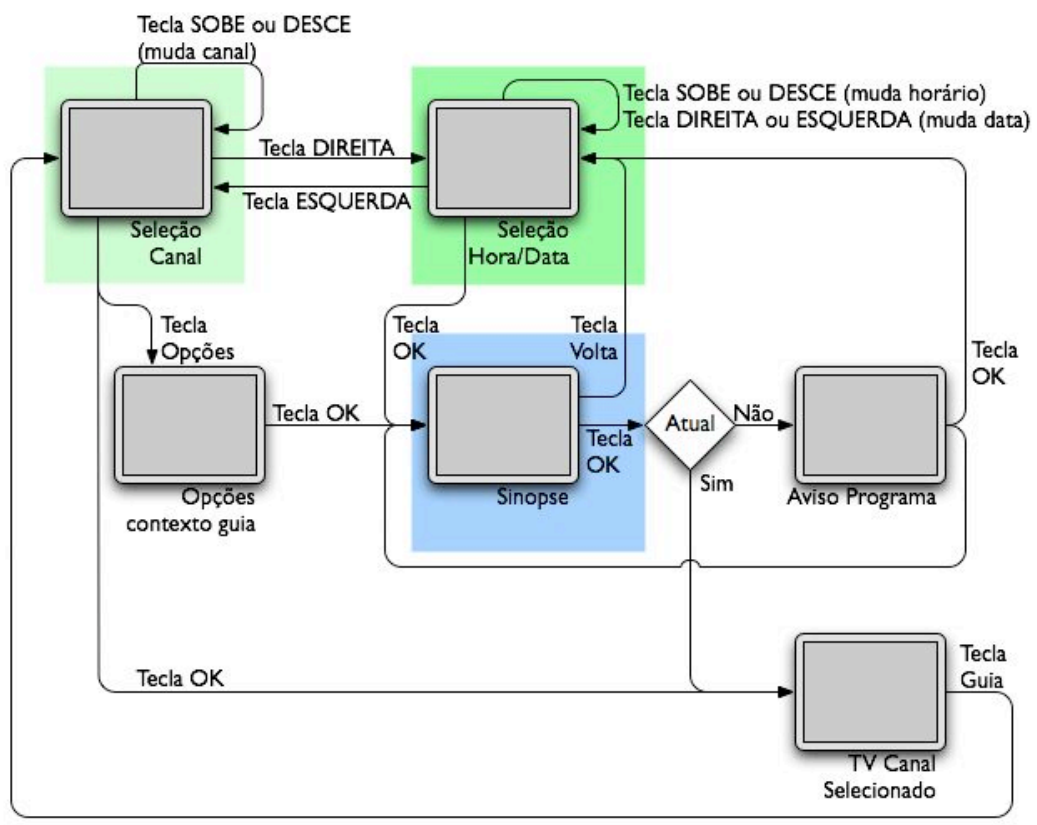

\begin{tabular}{|l|}
\hline Legenda \\
Ver Programação Atual \\
Ver Programaçâo em \\
Outro Horário \\
Ver Sinopse \\
\hline
\end{tabular}

Figura 4-118 - Navegação do guia no modelo proposto

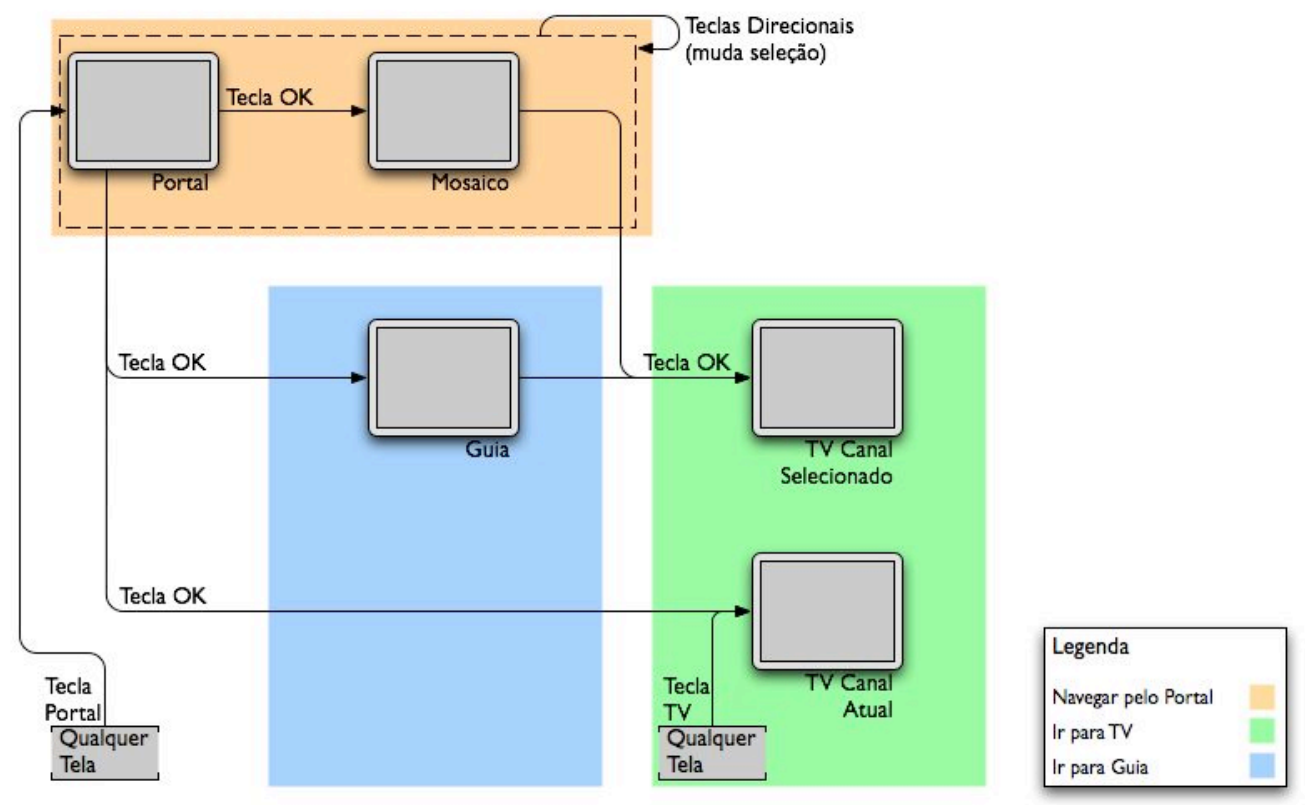

Figura 4-119 - Navegação do portal no modelo proposto 


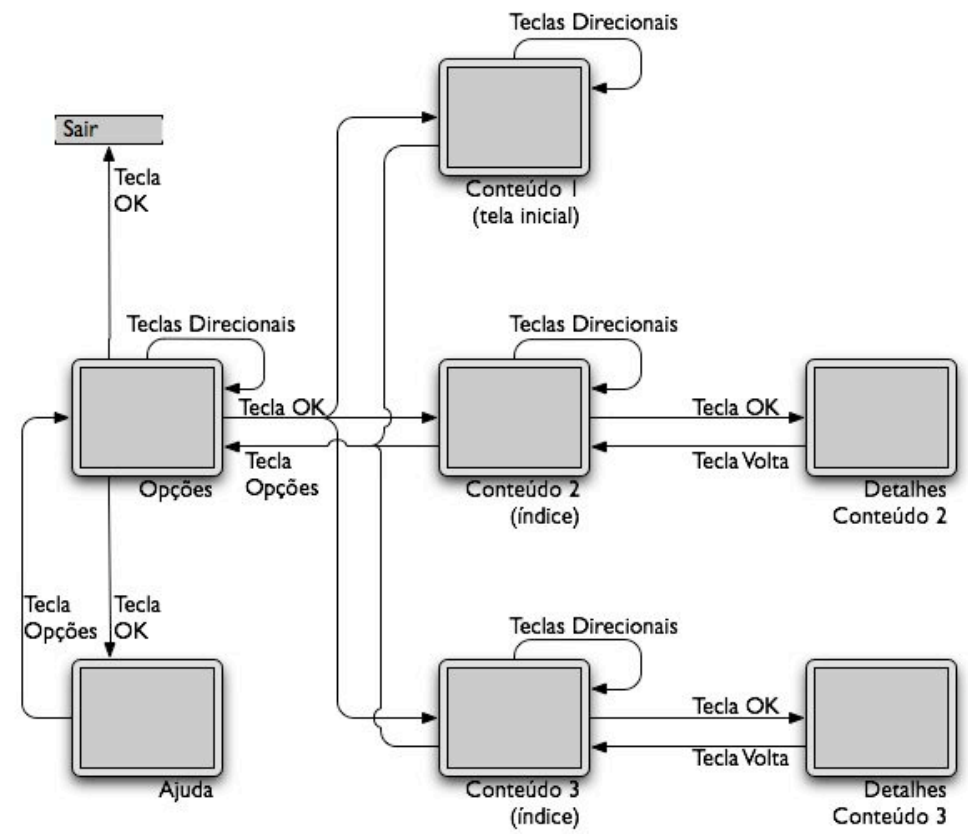

Figura 4-120 - Navegação de aplicativo de TV ativa no modelo proposto

Seguindo os fluxos de navegação propostos foram elaboras quatro tabelas das ações necessárias para tarefas típicas nos quatro contextos de uso comparando as plataformas analisadas e o modelo proposto, apresentadas a seguir.

Tabela 4-5 - Teclas utilizadas para tarefas típicas no contexto de TV

\begin{tabular}{|c|c|c|c|c|c|}
\hline & DirecTV & TVA & NET & $\begin{array}{l}\text { SKY e } \\
\text { SKY+ }\end{array}$ & Proposta \\
\hline \multicolumn{6}{|c|}{ Utilizar tarja de informações } \\
\hline $\begin{array}{l}\text { Abrir tarja de } \\
\text { informações }\end{array}$ & Info & $\begin{array}{l}\text { Setas ver- } \\
\text { ticais }\end{array}$ & Info & $?$ & OK \\
\hline $\begin{array}{l}\text { Ver programa- } \\
\text { ção próximo ca- } \\
\text { nal }\end{array}$ & -- & $\begin{array}{l}\text { Seta para } \\
\text { cima }\end{array}$ & $\begin{array}{l}\text { Seta para } \\
\text { cima }\end{array}$ & $\begin{array}{l}\text { Seta para } \\
\text { cima }\end{array}$ & $\begin{array}{l}\text { Seta para } \\
\text { cima }\end{array}$ \\
\hline $\begin{array}{l}\text { Sintonizar pró- } \\
\text { ximo canal }\end{array}$ & $\begin{array}{l}\text { Setas dire- } \\
\text { cionais }\end{array}$ & SEL & OK & $\mathbf{O}$ & OK \\
\hline \multicolumn{6}{|c|}{ Ver sinopse do programa atual } \\
\hline Abrir sinopse & $\begin{array}{l}\text { Info (2 ve- } \\
\text { zes) }\end{array}$ & $\begin{array}{l}\text { Sinopse (2 } \\
\text { vezes) }\end{array}$ & $\begin{array}{l}\text { Info (2 ve- } \\
\text { zes) }\end{array}$ & $\begin{array}{l}\text { ? (abre tar- } \\
\text { ja) e + }\end{array}$ & $\begin{array}{l}\text { Opções, Se- } \\
\text { tas direcio- } \\
\text { nais e OK }\end{array}$ \\
\hline Voltar para TV & Info & Sinopse & Sair & $\begin{array}{l}+ \text { e } ?(\mathrm{fe}- \\
\text { cha tarja) }\end{array}$ & OK \\
\hline
\end{tabular}




\begin{tabular}{|c|c|c|c|c|c|}
\hline \multicolumn{6}{|c|}{ Alterar opções de legenda e áudio alternativo } \\
\hline $\begin{array}{l}\text { Abrir tarja de } \\
\text { legenda e áudio } \\
\text { alternativo }\end{array}$ & -- & Opções & Opções & + & $\begin{array}{l}\text { Opções, Se- } \\
\text { tas direcio- } \\
\text { nais e OK }\end{array}$ \\
\hline Escolher & $\begin{array}{l}\text { Subtitles e } \\
\text { Alt Audio } \\
\text { (n vezes) }\end{array}$ & $\begin{array}{l}\text { Setas di- } \\
\text { recionais } \\
\text { e SEL }\end{array}$ & $\begin{array}{l}\text { Verde e } \\
\text { Amarela (n } \\
\text { vezes) }\end{array}$ & $\begin{array}{l}\text { Setas ver- } \\
\text { ticais e } \\
\text { hori- } \\
\text { zontais (n }\end{array}$ & $\begin{array}{l}\text { Setas dire- } \\
\text { cionais e } \\
\text { OK }\end{array}$ \\
\hline Confirmar & -- & $\begin{array}{l}\text { Setas di- } \\
\text { recionais } \\
\text { e SEL }\end{array}$ & OK & vezes) & $\begin{array}{l}\text { Setas dire- } \\
\text { cionais e } \\
\text { OK }\end{array}$ \\
\hline
\end{tabular}

Tabela 4-6 - Teclas utilizadas para tarefas típicas no contexto de guia de programação

\begin{tabular}{|l|l|l|l|l|l|}
\hline & \multicolumn{1}{|c|}{ DirecTV } & \multicolumn{1}{|c|}{ TVA } & \multicolumn{1}{|c|}{ NET } & \multicolumn{1}{|l|}{$\begin{array}{l}\text { SKY e } \\
\text { SKY+ }\end{array}$} & \multicolumn{1}{|l|}{ Proposta } \\
\hline $\begin{array}{l}\text { Ir para programa no horário atual } \\
\text { grama atual } \\
\text { Selecionar pro- }\end{array}$ & $\begin{array}{l}\text { Setas verti- } \\
\text { cais }\end{array}$ & $\begin{array}{l}\text { Setas ver- } \\
\text { ticais }\end{array}$ & $\begin{array}{l}\text { Setas verti- } \\
\text { cais }\end{array}$ & $\begin{array}{l}\text { Setas verti- } \\
\text { cais }\end{array}$ & $\begin{array}{l}\text { Setas verti- } \\
\text { cais }\end{array}$ \\
\hline Ir para canal & OK/SEL & $\begin{array}{l}\text { SEL (2 } \\
\text { vezes })\end{array}$ & OK & O & OK \\
\hline $\begin{array}{l}\text { Ver sinopse para programa no horário atual } \\
\text { grama atual }\end{array}$ & $\begin{array}{l}\text { Setas dire- } \\
\text { cionais }\end{array}$ & $\begin{array}{l}\text { Setas di- } \\
\text { recionais }\end{array}$ & $\begin{array}{l}\text { Setas dire- } \\
\text { cionais }\end{array}$ & $\begin{array}{l}\text { Setas dire- } \\
\text { cionais }\end{array}$ & $\begin{array}{l}\text { Setas dire- } \\
\text { cionais }\end{array}$ \\
\hline $\begin{array}{l}\text { Ver sinopse } \\
\text { (nada) }\end{array}$ & SEL & Info & + & $\begin{array}{l}\text { Opções, } \\
\text { Setas dire- } \\
\text { cionais e } \\
\text { OK }\end{array}$ \\
\hline Voltar & -- & Sinopse & Voltar & Retornar & Volta \\
\hline
\end{tabular}

Tabela 4-7 - Teclas utilizadas para tarefas típicas no contexto de portal

\begin{tabular}{|l|l|l|l|l|}
\hline \multicolumn{1}{|c|}{ TVA } & \multicolumn{1}{|c|}{ NET } & \multicolumn{1}{|c|}{ SKY e SKY+ } & \multicolumn{1}{|c|}{ Proposta } \\
\hline \multicolumn{4}{|l|}{ Ir para TV via mosaico } \\
\begin{tabular}{|l|l|l|l} 
Selecionar menu \\
ou mosaico
\end{tabular} & $\begin{array}{l}\text { Setas direcio- } \\
\text { nais }\end{array}$ & $\begin{array}{l}\text { Setas direcio- } \\
\text { nais }\end{array}$ & $\begin{array}{l}\text { Setas direcio- } \\
\text { nais }\end{array}$ & $\begin{array}{l}\text { Setas direcio- } \\
\text { nais }\end{array}$ \\
\hline
\end{tabular}




\begin{tabular}{|l|l|l|l|l|}
\hline $\begin{array}{l}\text { Ir para menu ou } \\
\text { mosaico }\end{array}$ & SEL & OK & O \\
\hline Selecionar canal & $\begin{array}{l}\text { Setas direcio- } \\
\text { nais }\end{array}$ & $\begin{array}{l}\text { Setas direcio- } \\
\text { nais }\end{array}$ & $\begin{array}{l}\text { Setas direcio- } \\
\text { nais }\end{array}$ & $\begin{array}{l}\text { Setas direcio- } \\
\text { nais }\end{array}$ \\
\hline Ir para canal & SEL (2 vezes) & OK & O & OK \\
\hline Ir para guia de programação & $\begin{array}{l}\text { Setas direcio- } \\
\text { nais }\end{array}$ & $\begin{array}{l}\text { Setas direcio- } \\
\text { nais }\end{array}$ & $\begin{array}{l}\text { Setas direcio- } \\
\text { nais, O (me- } \\
\text { nu) e setas } \\
\text { direcionais }\end{array}$ & $\begin{array}{l}\text { Setas direcio- } \\
\text { nais }\end{array}$ \\
\hline Selecionar guia & SEL & OK & O & OK \\
\hline Ir para guia & SE & &
\end{tabular}

Tabela 4-8 - Teclas utilizadas para tarefas típicas no contexto de aplicativos de TV ativa

\begin{tabular}{|l|l|l|l|l|}
\hline & \multicolumn{1}{|c|}{ NET } & \multicolumn{1}{|c|}{ SKY } & \multicolumn{1}{c|}{ SKY+ } & \multicolumn{1}{|c|}{ Proposta } \\
\hline $\begin{array}{l}\text { Selecionar conte- } \\
\text { údo 1 }\end{array}$ & $\begin{array}{l}\text { Setas horizon- } \\
\text { tais }\end{array}$ & (nada) & (nada) & (nada) \\
\hline Ver conteúdo 1 & OK & (nada) & (nada) & (nada) \\
\hline $\begin{array}{l}\text { Navegar por con- } \\
\text { teúdo 1 (local) }\end{array}$ & $\begin{array}{l}\text { Setas horizon- } \\
\text { tais }\end{array}$ & $\begin{array}{l}\text { Setas horizon- } \\
\text { tais }\end{array}$ & $\begin{array}{l}\text { Seta para bai- } \\
\text { xo, setas hori- } \\
\text { zontais e O }\end{array}$ & $\begin{array}{l}\text { Setas direcio- } \\
\text { nais }\end{array}$ \\
\hline $\begin{array}{l}\text { Selecionar conte- } \\
\text { údo 2 }\end{array}$ & $\begin{array}{l}\text { Vermelha (tela } \\
\text { inicial), setas } \\
\text { horizontais }\end{array}$ & $\begin{array}{l}\text { Setas horizon- } \\
\text { tais }\end{array}$ & $\begin{array}{l}\text { Seta para cima } \\
\text { e setas hori- } \\
\text { zontais }\end{array}$ & $\begin{array}{l}\text { Opções, setas } \\
\text { direcionais }\end{array}$ \\
\hline $\begin{array}{l}\text { Ver conteúdo 2 } \\
\text { (global) }\end{array}$ & OK & O & O & OK \\
\hline
\end{tabular}

A partir dos dados apresentados nestas tabelas é possível perceber que para as ações mais prováveis o modelo de navegação proposto é muito semelhante, senão igual, aos modelos utilizados atualmente, baseando-se nas setas direcionais e tecla de confirmação. Nas ações secundárias o modelo proposto exige mais ações por parte do usuário, pois é necessário primeiro ativar o menu de opções para depois executar a ação desejada. No entanto, todas as ações são feitas dentro deste modelo único, que é consistente. 
Capítulo 5 - Discussão 
Neste capítulo procuramos apresentar as principais considerações sobre os resultados encontrados neste trabalho. Buscamos evidenciar as questões de maior relevância e analisar seus impactos práticos e teóricos. O capítulo também está estruturado de acordo com as cinco etapas do trabalho.

\subsection{Modelagem de Usuário}

As classificações de modelos de usuário apresentadas dividem-se em dois grupos, de acordo com a granularidade de informação que apresentam.

Um dos grupos procura classificar toda a população a partir de um ou alguns poucos critérios, como é o caso das classificações de Nieminen-Sundell e Väänänen-Vainio-Mattila (2003) e Quico e Damásio (2004).

O segundo grupo escolhe alguns modelos mais específicos e observa-os em maior profundidade, mas exclui usuários que não se adequam a nenhum deles, pois não se propõe a englobar toda a população. As classificações de Mayer (2003) e Carey (1996b) fazem parte deste segundo grupo.

Para a definição de modelos de usuário, o segundo tipo de classificação é o ideal, pois traz dados importante sobre as capacidades e expectativas dos diversos tipos de usuários. No entanto, este tipo de classificação é muito mais trabalhosa e difícil, justamente devido ao seu detalhamento e especificidade.

No caso da TV interativa o número e a variabilidade dos modelos de usuário são muito altos, devido à grande abrangência deste meio. Este mesmo problema já foi levantado por Nielsen (2006) para websites que têm um público-alvo muito abrangente, como sites de governo ou de notícias. A diferença no caso da TVi é que seu tamanho e alcance são ainda maiores que a internet, tornando o problema detectado por Nielsen ainda mais crítico. 
A grande variabilidade dos modelos de usuário poderia ser tratada com interfaces adaptáveis ("customizáveis") a cada modelo de usuário, alternativa encontrada em algumas interfaces de telefones celulares. Um problema deste enfoque é que a TV é um aparelho compartilhado por um grupo de usuários, e muitas vezes utilizado em grupo. A questão passa a ser então como detectar cada modelo de usuário sem ser intrusivo. Outro problema é o esforço necessário à customização inicial da interface, em especial para usuários com menor intimidade com a tecnologia. Uma boa alternativa neste caso é o uso de interfaces cuja complexidade é apresentada de forma progressiva (progressive disclosure). Desta forma apenas as funcionalidades mais importantes são visíveis inicialmente, passando uma impressão de simplicidade. Para acessar as funcionalidades avançadas os usuários mais experientes podem utilizar submenus ou outros mecanismos de navegação.

Outro ponto que merece atenção diz respeito a um fenômeno chamado por Norman (1990, p. 42) de incapacidade adquirida (learned helplessness). Este mecanismo ocorre quanto um usuário falha ao tentar realizar uma tarefa, normalmente muitas vezes. Como resultado, o usuário chega à conclusão que é incapaz de realizar a tarefa e simplesmente desiste de tentar novamente. Este fenômeno é crítico nos usuários com baixa familiaridade com a tecnologia, onde o insucesso recorrente na tentativa de utilização da tecnologia tem efeitos negativos na sua auto-estima e auto-confiança, aumentando sua insegurança, aversão e apreensão frente à tecnologia.

Segundo Norman (Ibid.) este fenômeno é agravado por interfaces mal projetadas, causando o que ele chama de incapacidade ensinada (taught helplessness). De forma inversa, interfaces bem projetadas, onde o usuário tem sucesso nas realização de suas tarefas, trazem uma sensação de realização e controle, contribuindo positivamente para a auto-confiança (KAY, 1989). O melhor mecanismo para reverter a síndrome da incapacidade ensinada é o design de boas interfaces com o usuário, simples e de fácil utilização.

Um último ponto a ser levantado é a relação entre os modelos de usuários e a consistência de interfaces. Na Tabela 5-1 apresentamos os requisitos listados no item 4.1 e seus respectivos modelos de usuário.

Tabela 5-1 - Relação entre requisitos e modelos de usuários 


\begin{tabular}{|c|c|c|c|c|}
\hline & $\begin{array}{l}\text { Torcedor } \\
\text { Antenado }\end{array}$ & $\begin{array}{c}\text { Mãe } \\
\text { Ocupada }\end{array}$ & $\begin{array}{l}\text { Meia Idade } \\
\text { com Ajuda }\end{array}$ & $\begin{array}{l}\text { Torcedor com } \\
\text { Baixa Alfab. }\end{array}$ \\
\hline $\begin{array}{l}\text { Facilidade de } \\
\text { memorização }\end{array}$ & & & $X$ & \\
\hline Estabilidade & & & $X$ & \\
\hline $\begin{array}{l}\text { Facilidade de } \\
\text { aprendizagem }\end{array}$ & & & & $X$ \\
\hline $\begin{array}{l}\text { Satisfação } \\
\text { subjetiva }\end{array}$ & $X$ & $X$ & $X$ & $X$ \\
\hline Facilidade de uso & $X$ & $X$ & $X$ & $X$ \\
\hline
\end{tabular}

Conforme apresentado no item 2.1, a consistência contribui para quase todos os requisitos listados acima, inclusive para dois requisitos que são válidos para qualquer modelo de usuário (satisfação subjetiva e facilidade de uso). Isto é esperado, visto que a consistência é considerada um atributo-chave para a uma boa usabilidade. Não obstante, é interessante evidenciar a sua relação com os modelos de usuários deste trabalho.

\subsection{Análise de Tarefa}

O estudo das tarefas e do uso da TVi está muito ligado ao estudo do ambiente domiciliar e de suas características. Diferente do ambiente de trabalho, onde fatores socioculturais podem ser reduzidos, a residência é um espaço grandemente influenciado pelos seus habitantes e seu contexto social. Desta forma é necessário muito cuidado com estudos desenvolvidos em outros países, pois a variável sociocultural pode ser radicalmente diferente.

No âmbito desta dissertação decidiu-se concentrar os estudos em dois dos modelos de usuário propostos, o modelo Torcedor Antenado e o modelo Mãe Ocupada, e realizar uma análise aprofundada para estes dois modelos 
considerados. Os dois outros modelos, o modelo Meia Idade com Ajuda e o modelo Torcedor com Baixa Alfabetização, deverão ser avaliados em trabalhos que darão seqüência a este estudo.

Uma consideração metodológica importante neste estudo foi a escolha de uma entrevista com usuários, sem observação. Uma limitação da entrevista é que por razões voluntárias ou não o que o usuário relata não é necessariamente o que ele faz (NIELSEN, 1994, p. 214). Para reduzir este impacto nas entrevistas foi solicitado aos usuários a demonstração das tarefas, enquanto explicavam suas motivações para fazer de uma determinada maneira (método think aloud). A grande vantagem da entrevista sobre a observação é que ela pode ser direcionada por questões e tarefas específicas, aumentando muito a eficiência na coleta de dados.

Entrevistas feitas em laboratório também têm a grande desvantagem de não coletar dados de contexto de uso, que são muito importantes e que muitas vezes os próprios usuários não são capazes de enunciar (MAYHEW, 1999, p. 81). Por este motivo as entrevistas foram feitas no ambiente de uso, e portanto são chamadas de entrevistas contextuais.

Um dado interessante nesta etapa do trabalho foi o impacto das diferentes tecnologias (TV a cabo analógica, TV digital e PVR) nas tarefas dos usuários. Durante a avaliação os usuários de TV digital não trocaram de canal sintonizando os canais um por um, como é feito na TV analógica, mas primeiro utilizaram a tarja de informações ou o guia de programação para selecionar o programa de interesse e somente então trocam de canal. Não é possível dizer se este comportamento será mantido em situações onde o número de canais é muito menor, como acontece na TV aberta. Todos os usuários deste estudo tinham no mínimo 40 canais à disposição. Outro motivo para preferirem esta estratégia é que o tempo necessário para sintonizar um canal é muito maior na TV digital. Enquanto na TV analógica a troca de canal se completa (imagem formada na tela) em menos de meio segundo, na TV digital isto dificilmente acontece em menos de um segundo e meio, e não é difícil que leve até três segundos. A troca de informações na tarja de informações, por outro lado, é praticamente instantânea. 
Outro impacto tecnológico é a possibilidade de gravação de conteúdo do PVR. Os dois usuários entrevistados que tinham este recurso checavam não apenas a programação atual da TV mas também a das próximas horas ou do resto do dia para gravarem programas que pudessem lhes interessar. No entanto, ambos davam preferência a programas que estivessem passando no momento e deixavam os programas gravados como uma última opção.

Por uma questão de escopo este estudo fez apenas uma breve análise destes impactos. Mesmo assim é possível dizer que estas tecnologias modificam os hábitos dos usuários e que estas tarefas podem se modificar substancialmente nos próximos anos.

O uso do guia de programação ou a tarja de informação para ver a programação em outros canais foi outro dado encontrado. Inicialmente era esperado que num primeiro momento (ver o que está passando em diversos canais) o guia de programação fosse preferido, enquanto que a tarja seria utilizada quando um programa já estivesse sendo assistido, mas não foi isto o encontrado. Apenas um usuário utilizou o guia de programação e faz isto mesmo quando já está assistindo um programa (vai até o guia, troca de canal e volta para a TV). Os usuários que preferem a tarja freqüentemente diziam que o guia era "muita coisa" para ser vista ao mesmo tempo. Já o único usuário que prefere o guia de programação alegou justamente o motivo inverso para não utilizar a tarja, pois nela "não dá para ver nada". Isto pode indicar uma preferência pessoal pela quantidade de informações que o usuário deseja.

\subsection{Diretrizes Gerais de Interface}

As recomendações utilizadas neste trabalho foram extraídas de documentos produzidos em outros países, nominalmente Reino Unido, Finlândia e Estados Unidos. Estes países têm um histórico de TV digital e até de interação com a TV analógica através do Teletexto (no caso do Reino Unido e Finlândia), que faz com que já existam hábitos e práticas estabelecidas e conhecidas pelos usuários, o que não é o caso no Brasil.

Podemos falar especificamente do uso de teclas coloridas e da tecla Text para acesso ao teletexto. Tanto no Reino Unido quanto na Finlândia (de onde 
vêm 5 dos 6 documentos utilizados) estes paradigmas já existem na TV analógica e portanto são conhecidos pela população.

No caso brasileiro não existe a motivação histórica que levou estes países a transpor estes paradigmas de interação para a TV digital e portanto deve-se questionar sua validade e verificar sua aplicabilidade. É importante notar que a transposição destas funcionalidades no Reino Unido do sistema analógico para o digital gerou diversos problemas de usabilidade e não se apresenta como uma solução satisfatória (GAWLINSKI, 2003).

De forma mais geral, os documentos utilizados foram as melhores recomendações encontradas, mas devem ser utilizadas com muito critério. Por exemplo, tanto o guia da BBC (2002) quanto Gawlinski (2003) ressaltam o fato de que não existe um sistema de navegação consistente no Reino Unido e que isto traz graves conseqüências para a usabilidade da TV interativa como um todo. Desta forma, as recomendações destes documentos devem ser utilizadas como referência, mas jamais como um modelo a ser seguido sem uma avaliação criteriosa de sua validade.

As recomendações de design para TV também são voltadas para as telas de TV que existem atualmente, de tubo de raios catódicos (CRT) e definição padrão (SDTV). Com a mudança para televisores de alta definição (HDTV) e que utilizam outras tecnologias como o LCD ou Plasma estas recomendações devem ser revistas. Mas isto será uma mudança lenta e gradual, uma vez que a grande maioria dos aparelhos ainda utiliza CRT e definição padrão.

\subsection{Análise Comparativa}

Através da análise comparativa foi possível perceber que certas partes das plataformas analisadas são muito semelhantes, como é o caso do mapa de navegação e da tarja de informações. No caso dos guias de programação surgem dois tipos de soluções, uma baseada em dois painéis separados de canais e horários e outra baseada em uma grade única com canais na vertical e horários na horizontal. Mas mesmo neste caso, onde as formas de apresentação da informação são diferentes, a navegação utilizada é a mesma, baseada nas setas direcionais e na tecla de confirmação. 
As maiores diferenças encontradas não estavam nas interações principais, como as citadas acima, mas em interações secundárias, como a visualização da sinopse no contexto de TV, a ativação de aviso no guia de programação e a navegação nos aplicativos de TV ativa. Estas diferenças foram observadas não apenas entre plataformas mas também dentro de uma mesma plataforma. Por exemplo, a visualização da sinopse é feita de forma distinta nos contextos de TV e de guia de programação.

A diferença dentro da mesma plataforma cria uma inconsistência interna da interface que, conforme visto no item 2.1, dificulta a aprendizagem e uso do sistema. Ao invés de um sistema coeso com algumas regras generalizáveis o usuário aprende diversas regras específicas para cada situação. Desta forma, usuário forma um modelo mental fragmentado do sistema (NORMAN, 1990) e quando se depara com uma situação nova não é capaz de dizer quais regras devem ser seguidas. A diferença entre as plataformas dificulta a produção de aplicativos consistentes com as diversas plataformas e portanto tem um efeito negativo direto para os produtores de conteúdo e indireto para o usuário final, conforme visto no item 2.2.3.

\subsection{Coordenação da Interface}

Considerando a afirmação que encerra o item anterior, a etapa de coordenação da interface procurou elaborar propostas de soluções que possam vir a se tornar padrões utilizados em TVi.

À luz das recomendações e utilizando como referências as soluções encontradas na análise comparativa, as propostas elaboradas buscaram constituir uma solução consistente e integrada de design de interfaces para TVi. Uma vez que neste trabalho não foram realizados testes com usuários finais estas propostas devem ser vistas como hipóteses de trabalho a serem confirmadas por uma validação experimental. Através desta validação, e do ciclo iterativo que naturalmente deve acompanhá-la, poderá surgir um modelo a ser amplamente utilizado em TVi.

Além das propostas apresentadas na coordenação da interface, outras soluções surgiram durante a elaboração deste trabalho, e uma em particular me- 
rece ser mencionada. No modelo de navegação proposto em 4.5 .4 a tecla de confirmação executa a ação mais provável e a tecla de opção mostra as opções disponíveis. O enfoque alternativo considerado dispensa a tecla de opções e sempre que a tecla de confirmação é pressionada, são apresentadas as opções disponíveis, com a ação mais provável pré-selecionada. Desta forma o usuário poderia pressionar a tecla de confirmação uma vez para acessar as opções e duas vezes consecutivas para ativar a opção mais provável. A grande vantagem deste enfoque é que ele é mais simples do que o modelo proposto, visto que o acesso ao menu de opções não requer o uso de uma tecla distinta. No entanto, ele tem um impacto negativo em termos do número de teclas que devem ser pressionadas, conforme podemos ver na Tabela 5-2. 
Tabela 5-2 - Comparação entre o modelo de navegação proposto e a solução alternativa

\begin{tabular}{|c|c|c|}
\hline & Modelo Proposto & Solução Alternativa \\
\hline \multicolumn{3}{|l|}{ Utilizar tarja de informações (TV) } \\
\hline Abrir tarja de informações & OK & OK (2 vezes) \\
\hline Ver programação próximo canal & Seta para cima & Seta para cima \\
\hline Sintonizar próximo canal & OK & OK (2 vezes) \\
\hline Número de teclas pressionadas & 3 & 5 \\
\hline \multicolumn{3}{|l|}{ Ver sinopse do programa atual (TV) } \\
\hline Abrir sinopse & $\begin{array}{l}\text { Opções, Setas direcio- } \\
\text { nais e OK }\end{array}$ & $\begin{array}{l}\text { OK, Setas direcionais } \\
\text { e OK }\end{array}$ \\
\hline Voltar para TV & OK & OK \\
\hline Número de teclas pressionadas & 4 & 4 \\
\hline \multicolumn{3}{|c|}{ Alterar opções de legenda e áudio alternativo (TV) } \\
\hline $\begin{array}{l}\text { Abrir tarja de legenda e áudio } \\
\text { alternativo }\end{array}$ & $\begin{array}{l}\text { Opções, Setas direcio- } \\
\text { nais e OK }\end{array}$ & $\begin{array}{l}\text { OK, Setas direcionais } \\
\text { e OK }\end{array}$ \\
\hline Escolher & Setas direcionais e OK & Setas direcionais e OK \\
\hline Confirmar & Setas direcionais e OK & Setas direcionais e OK \\
\hline Número de teclas pressionadas & 7 & 7 \\
\hline \multicolumn{3}{|c|}{ Ir para programa no horário atual (guia) } \\
\hline Selecionar programa atual & Setas verticais & Setas verticais \\
\hline Ir para canal & OK & OK (2 vezes) \\
\hline Número de teclas pressionadas & 2 & 3 \\
\hline \multicolumn{3}{|l|}{ Ir para TV via mosaico } \\
\hline Selecionar menu ou mosaico & Setas direcionais & Setas direcionais \\
\hline Ir para menu ou mosaico & OK & OK (2 vezes) \\
\hline Selecionar canal & Setas direcionais & Setas direcionais \\
\hline Ir para canal & OK & OK (2 vezes) \\
\hline Número de teclas pressionadas & 4 & 6 \\
\hline
\end{tabular}

Os dados da Tabela 5-2 mostram que nas interações secundárias (ver sinopse e alterar opções de legenda e áudio alternativo) o número de teclas pressionadas é o mesmo, o que é uma vantagem para o enfoque alternativo. No entanto, nas ações principais o número de teclas pressionadas aumenta significativamente. Uma vez que as ações principais são utilizadas com freqüência muito maior optamos pelo modelo que utiliza a tecla Opção e facilita o uso mais freqüente da interface. 


\section{Capítulo 6 - Conclusão}

“Nos estágios iniciais de uma indústria, quando a funcionalidade e robustez de um produto não são ainda adequados às demandas do cliente, a solução proprietária é quase sempre a correta - porque ela permite uma integração de todas as partes do sistema de uma forma otimizada.

Mas uma vez que a tecnologia amadurece e se torna suficientemente boa, padrões da indústria começam a surgir. Isto leva à padronização de interfaces, o que permite que empresas se especializem em partes específicas do sistema, e o produto se torna modular." ${ }^{5}$

${ }^{5}$ BURROWS, P. How Apple Could Mess Up, Again. Disponível em: <http:/ / www.businessweek.com/print/technology / content/jan2006/tc20060109_432937.ht $m>$. Acesso em: 03.02.06. Tradução do autor. 
Esta dissertação apresentou como principal proposta a investigação das questões relacionadas à consistência de interfaces com o usuário em TV interativa e a busca de exemplos de boas práticas que possam se tornar modelos a serem seguidos. $\mathrm{O}$ trabalho inicialmente proposto mostrou-se interessante $\mathrm{e}$ desafiador e o foco desta dissertação é relevante ao atual momento que o país atravessa, de definição da implantação do SBTVD. Durante o processo de investigação constatamos que a linha de pesquisa escolhida ainda se encontra aberta e trata-se de uma área muito instigante à pesquisa pelos grandes desafios na definição conceitual, desenvolvimento de aparatos metodológicos e validação de resultados.

No âmbito desta dissertação, portanto, procuramos elucidar questões e diminuir as lacunas da teoria e prática na concepção de interfaces com o usuário em TVi. Consideramos que esta dissertação foi mais um esforço nesta área de conhecimento.

\subsection{Resultados}

Nesta sessão apresentamos pontualmente os vários resultados diretos e indiretos das atividades decorrentes desta dissertação.

No capítulo dois apresentamos os aspectos fundamentais encontrados na bibliografia relacionados à consistência e à TV interativa. Investigamos como os vários autores tratam a questão da consistência do ponto de vista de concepção e projeto de interfaces com o usuário. Apresentamos de forma crítica nossas considerações sobre a consistência. Neste capítulo discutimos ainda, à luz da literatura, questões relacionadas com a TV interativa como suas categorias, sua usabilidade e a própria questão da consistência na TVi, evidenciando sua importância. 
O principal resultado do capítulo 3 é a descrição de uma metodologia para a seleção de boas práticas de interfaces de TVi. Esta metodologia compreende um levantamento do modelo dos usuários, a análise de suas tarefas e os contextos onde ocorrem, um levantamento das diretrizes de interface relevantes, uma análise comparativa de plataformas de TVi e a coordenação das boas práticas elencadas. Os aspectos mais relevantes deste capítulo foram os modelos de usuários postulados e sua validação com especialistas na etapa de modelagem de usuários, a escolha das tarefas e o uso de entrevistas contextuais na etapa de análise de tarefas e por fim a taxonomia utilizada na etapa de análise comparativa. Este capítulo criou as condições para os estudos e trabalhos desenvolvidos no capítulo 4.

O capítulo 4 apresenta resultados relacionados com os aspectos experimentais da metodologia proposta no capítulo 3. Sistematizamos os diversos experimentos realizados de forma progressiva e coerente com a metodologia proposta. Apresentamos 4 modelos de usuários, a saber: Torcedor Antenado, Mãe Ocupada, Meia Idade com Ajuda e Torcedor com Baixa Alfabetização. $\mathrm{Na}$ análise da tarefa detalhamos as tarefas e o contexto de uso para os modelos de Torcedor Antenado e Mãe Ocupada. Ainda neste capítulo apresentamos uma compilação das diretrizes de interface consideradas relevantes. A seguir foi realizada uma extensa análise comparativa entre sete plataformas de TV. A etapa de coordenação de interfaces, onde são elaboradas propostas de modelos para interfaces de TVi conclui o capítulo.

O capítulo 5 apresenta a discussão da metodologia proposta à luz dos resultados experimentais do capítulo 4 . Na discussão sobre os modelos de usuário tecemos considerações sobre as várias classificações de usuários encontradas na literatura e discorremos sobre os critérios adotados na proposta dos nossos modelos. Apresentamos algumas considerações sobre a metodologia utilizada na análise de tarefas, nas diretrizes de interface e sobre seus possíveis impactos nos resultados. Por fim descrevemos um modelo de navegação alternativo, suas características e a motivação que nos levou a descartá-lo em favor do modelo proposto. 


\subsection{Contribuições}

Esta sessão apresenta as principais contribuições científicas obtidas ao longo do desenvolvimento desta dissertação, incluindo os artigos publicados oriundos desta pesquisa.

A principal contribuição deste trabalho foi a elaboração de um conjunto de propostas de interfaces de TVi, que incluem:

- um mapa de navegação;

- um conjunto de funcionalidades mínimas para o controle remoto;

- um modelo de navegação adequado à TVi;

- recomendações para telas de aplicativos de TVi;

Estas propostas constituem um exemplo de interface de TVi consistente e integrada, ou seja, que considera as diversas partes da interface como um conjunto único. Esta é uma etapa inicial do processo que necessita de uma validação experimental, descrita no próximo item.

Outras contribuições foram:

- a análise crítica da importância da consistência em TVi, evidenciando seus benefícios aos diversos atores que compõem a cadeia de produção de TVi;

- quatro modelos de usuários de TVi no Brasil, que podem ser utilizados como uma referência para extensão e refinamento desta modelagem para públicos mais específicos;

- uma compilação de diretrizes gerais de interface para TVi.

Ao longo do desenvolvimento desta dissertação foram publicados os seguintes artigos:

BARROS, Gil; BENINI, Julia; ZUFFO, Marcelo K. Home Entertainment UI Continuum: Cell Phone, HTPC and iTV. In Investigating New User Experience Challenges In ITV: Mobility \& Sociability, CHI 2006, 2006, Montreal, Canadá.

BARROS, Gil; FAUST, Richard; ZUFFO, Marcelo K.; GONTIJO, Leila A. Usabilidade de Aplicações e Tecnologias Emergentes: a Necessidade de uma "Nova Usabilidade"? In IHC 2006, Simpósio sobre fatores humanos em sistemas computacionais, Natal, RN, Brasil, 19-22 de novembro, 2006. No prelo. 
FILGUEIRAS, Lucia V. L.; ALMAS, Almir; SHCLITTLER, João Paulo; OLIVEIRA NETO, João S. de; GIANNOTTO, Eduardo; BARROS, Gil; ZUFFO, Marcelo K. Processos de software para televisão digital interativa. In: TVDI 2006 - IV Fórum de Oportunidades em Televisão Digital Interativa, 2006, Poços de Caldas. Anais do IV Fórum de Oportunidades em Televisão Digital Interativa. Poços de Caldas : Pontifícia Universidade Católica de Minas Gerais, 2006.

\subsection{Trabalhos Futuros}

A proposta elaborada neste trabalho seguiu as recomendações encontradas e buscou a consistência e coordenação interna da interface. No entanto, conforme apresentado no item 5.5, neste trabalho não foram realizados testes com usuários finais. Portanto, como trabalhos futuros podemos citar a prototipação e realização de testes com usuários finais das propostas elaboradas neste trabalho. Os testes com usuários, e o ciclo iterativo de desenvolvimento e design que os acompanha deverão aprimorar a proposta e eventualmente validá-la.

Uma vez obtida uma proposta validada experimentalmente os passos seguintes neste processo podem ser:

- a criação de um guia de estilo geral para aplicativos de TVi;

- a elaboração de uma biblioteca de design patterns específicas para TVi;

- o desenvolvimento de protótipos funcionais que possam ser utilizados como exemplos de boas práticas em TVi;

- a orientação ao desenvolvimento de bibliotecas de código para serem reutilizadas em aplicativos de TVi.

Conforme citado no item 5.2, apenas dois modelos de usuários foram utilizados na análise de tarefas. Os dois modelos restantes deverão ser analisados em etapas posteriores deste trabalho, de forma a enriquecer sua análise.

Como este foi um trabalho inicial sobre a TV interativa no Brasil foi priorizado um enfoque mais abrangente. Outros trabalhos que envolvam públicos mais específicos poderão refinar as análises aqui elaboradas para seus públicos de interesse. Um público em particular que deve ser muito beneficiado 
pelas novas possibilidades da TV interativa são os usuários com necessidades especiais. Apesar de não terem sido objeto de estudo específico deste trabalho, deverão ser abordados em trabalhos futuros.

\subsection{Considerações Finais}

Esta dissertação consolidou o trabalho de pesquisa e desenvolvimento realizado ao longo dos últimos 3, anos que foram simultâneos ao intenso processo de definição da TV digital no Brasil, no âmbito do SBTVD. Particularmente a elaboração deste trabalho foi feita entre 2004 e 2006, justamente no período que compreende os decretos presidenciais relacionados com o SBTVD, no caso o decreto de instituição do SBTVD, de 03 de novembro de 2003 e o decreto de definição, de 29 de junho de 2006.

No âmbito destes acontecimentos estivemos extremamente envolvidos com o debate acerca das implicações da implantação da TV digital no Brasil; foram diversos debates, seminários, discussões e consolidações de relatórios técnicos e artigos científicos publicados nacionalmente e internacionalmente. Acima de tudo, havia a percepção da importância desta dissertação diante da sua atualidade, tanto no sentido de sistematizar o conhecimento aqui apresentado, quanto de abrir frentes de desenvolvimento passíveis de incorporação pela sociedade brasileira. 


\section{Referências}

APPLE COMPUTER. Macintosh Human Inteface Guidelines. New York: Addison Wesley, 1992.

ARVID. A Guide for Digital TV Service Producers. Finland: Arvid, 2004.

BBC. Interactive Television Style Guide. UK: BBC, 2002.

BARROS, Gil; BENINI, Julia; ZUFFO, Marcelo K. Home Entertainment UI Continuum: Cell Phone, HTPC and iTV. In Investigating New User Experience Challenges In ITV: Mobility \& Sociability, CHI 2006, 2006, Montreal, Canadá.

BARROS, Gil; FAUST, Richard; ZUFFO, Marcelo K.; GONTIJO, Leila A.

Usabilidade de Aplicações e Tecnologias Emergentes: a

Necessidade de uma “Nova Usabilidade"? In IHC 2006, Simpósio sobre fatores humanos em sistemas computacionais, Natal, RN, Brasil, 19-22 de novembro, 2006. No prelo.

BECKER, Valdecir. Concepção e Desenvolvimento de Aplicações Interativas para Televisão Digital. Florianópolis: Universidade Federal de Santa Catarina, 2006. Dissertação submetida à Universidade Federal de Santa Catarina para a obtenção do Grau de Mestre em Engenharia e Gestão do Conhecimento.

BENINI, Maria Júlia; BATISTA, Leandro L.; ZUFFO, Marcelo K. When marketing meets usability: the consumer behavior in heuristic evaluation for web. Proceedings of the 2005 Latin American Conference on Human-Computer interaction (Cuernavaca, Mexico, October 23 - 26, 2005). CLIHC '05, vol. 124., ACM Press, New York, NY, 2005. 307-312 p. 
BEYER, Hugh; HOLTZBLATT, Karen. Contextual Design: A CustomerCentered Approach to Systems Designs. Morgan Kaufmann, 1997. $496 \mathrm{p}$.

BONNICI, Sabina. Which channel is that on?: A design model for electronic programme guides. Proceedings of the 1st European Conference on Interactive Television: from Viewers to Actors?, University of Brighton, 2003.

BRASIL. Decreto No 5.820, de 29 de Junho de 2006. Dispõe sobre a implantação do SBTVD-T, estabelece diretrizes para a transição do sistema de transmissão analógica para o sistema de transmissão digital do serviço de radiodifusão de sons e imagens e do serviço de retransmissão de televisão, e dá outras providências. Diário Oficial da União, Brasília, DF, 29 Jun 2006.

BROADBAND. iTV Video Vault. Broadband Bananas, 2006. Disponível em: $<$ http:/ / broadbandbananas.com/videovault.html>. Acesso em: 18 Jun 2004.

CAREY, John. Winky Dink To Stargazer: Five Decades of Interactive Television. In Responsibility In The New Media Landscape, CONTAMINE, C et al. (eds.), Amsterdam: European Institute For The Media, 1996.

CAREY, John. An Ethnographic Study of Interactive Television. CONFERENCE ON INTERACTIVE TELEVISION, Edinburgh, Scotland: University of Edinburgh, 1996.

CAREY, John. Interactive television trials and marketplace experiences. Multimedia Tools and Applications, 5, Kluwer Academic Publishers, 1997. 207-216 p.

CHORIANOPOULOS, Konstantinos. Virtual Television Channels:

Conceptual Model, User Interface Design and Affective Usability Evaluation. , 2004. 180 p. Thesis submitted for the degree of Doctor of Philosophy Department of Management Science and Technology Athens University of Economics and Business.

COOPER, Alan; REIMANN, Robert. About Face 2.0: The Essentials of Interactin Design. Indinapolis, USA: Wiley Publishing, 2003. 504 p. 
CPQD. Mapeamento da Demanda: Pesquisas de Mercado e Análise de Tendências. Campinas: CPqD, 2004.

DALY-JONES, Owen. Case study: The usability of electronic programme guides. In: Gawlinski, M., Interactive Television Production, Focal Press, 2003. 288 p.

DIX, Alan; FINLAY, Janet E.; ABOWD, Gregory D.; BEALE, Russell. HumanComputer Interaction. Prentice Hall, 1998.

DRUCKER, Steven M.; GLATZER, Asta; DE MAR, Steven; WONG, Curtis. SmartSkip: consumer level browsing and skipping of digital video content. CHI '02: Proceedings of the SIGCHI conference on Human factors in computing systems, New York: ACM Press, 2002. 219-226 p.

FILGUEIRAS, Lucia V. L.; ALMAS, Almir; SHCLITTLER, João Paulo; OLIVEIRA NETO, João S. de; GIANNOTTO, Eduardo; BARROS, Gil; ZUFFO, Marcelo K. Processos de software para televisão digital interativa. In: TVDI 2006 - IV Fórum de Oportunidades em Televisão Digital Interativa, 2006, Poços de Caldas. Anais do IV Fórum de Oportunidades em Televisão Digital Interativa. Poços de Caldas : Pontifícia Universidade Católica de Minas Gerais, 2006.

FREED, Ken. Interactive TV For Newbies. , 2000. Disponível em: <http: / / www.media-visions.com/itv- newbies.html>. Acesso em: 11 Jul 2005.

FREEMAN, Jonathan; LESSITER, Jane. ITC-UsE : Ease of Use and Knowledge of Digital and Interactive Television: Results. London: University of London, 2001.

FREEMAN, Jonathan; LESSITER, Jane. Easy TV 2002 Research Report. London: University of London, 2003.

GAWLINSKI, Mark. Interactive Television Production. Focal Press, 2003. 288 p. HEDMAN, Anders. A Media Rich Interface vs A Simple Interface for Interactive Television. Proceedings of E-Learn 2002 World Conference, Montreal, Canada, 2002.

IBGE. Pesquisa Nacional por Amostra de Domicílios: Síntese de Indicadores 2003. Rio de Janeiro: IBGE, 2004. 
INSTITUTO PAULO MONTENEGRO. 5o Indicador Nacional de

Alfabetismo Funcional. São Paulo: Instituto Paulo Montenegro, 2005.

IPSOS. Ferryside and Llansteffan Digital Switchover Technical Trial:

Research on Vulnerable Households. 2005.

ISO. Ergonomic requirements for office work with visual display terminals

(VDTs): Part 11. ISO 9241-11, ISO - International Organization for

Standardization, 1998.

JU, Ginny; ANGIOLILLO, Joel S.; HICKS, J. Al. The Challenges of Designing

a User Interface for Consumer Interactive Television. IEEE, 1994.

KAY, Robin H. A practical and theoretical approach to assessing computer attitudes: The computer attitude measure (CAM). Journal on

Research on Computing in Education, 1989. 456-463 p.

KLEIN, Jeremy ; KARGER, Simon ; SINCLAIR, Kay. Digital Television For

All: A report on usability and accessible design. Cambridge, UK: The Generics Group, 2003.

KLEIN, Jeremy ; KARGER, Simon ; SINCLAIR, Kay. Attitudes to Digital

Television: Preliminary findings on consumer adoption of Digital

Television. Cambridge, UK: The Generics Group, 2004.

KÖLTRINGER, Thomas; TOMITSCH, Martin; KAPPEL, Karin; KALBECK,

Daniel. Implications for Designing the User Experience of DVD

Menus. CHI '05 extended abstracts on Human factors in computing systems, New York: ACM Press, 2005. 1565-1568 p.

LAMONT, Sheri. An 8-step process for creating compelling enhanced television. Proceedings of the 1st European Conference on Interactive Television: from Viewers to Actors?, University of Brighton, 2003.

LIBERATE. Interactive Television Design Guide. Liberate Technologies, 2002. LOIZIDES, Lydia. Interactive TV: Dispelling Misconceptions in the Media.

ACM Computers in Entertainment, Vol. 3, No. 1, 2005.

LU, Karyn Y. Interaction Design Principles for Interactive Television.

Georgia Institute of Technology, 2005. 202 p. Thesis Presented to The 
Academic Faculty Degree Master of Science in Information Design and Technology.

MAYER, Andy. Case study: Hands on TV - Interactive television consumer research. In: Gawlinski, M., Interactive Television Production, Focal Press, 2003. 288 p.

MAYHEW, Deborah J.. The Usability Engineering Lifecycle: A Practitioner's Handbook for User Interface Design. Morgan Kaufmann, 1999. 542 p.

NIELSEN, Jakob. Usability Engineering. Morgan Kaufmann, 1994. 362 p.

NIELSEN, Jakob. Coordinating UI for Consistency. Morgan Kaufmann, 2002. $156 \mathrm{p}$.

NIELSEN, Jakob. Why Consumer Products Have Inferior User Experience. 2004.

Disponível em: <http: / / www.useit.com/alertbox/20040315.html>. Acesso em: 27 Jan 2005.

NIELSEN, Jakob. Remote Control Anarchy. 2004. Disponível em: <http: / / www.useit.com/alertbox/20040607.html>. Acesso em: 27 Jan 2005.

NIELSEN, Jakob. Variability in User Performance. 2006. Disponível em: <http:/ / www.useit.com/alertbox/ performance_variability.html>. Acesso em: 06 Jul 2006.

NIEMINEN-SUNDELL, Riitta; VÄÄNÄNEN-VAINIO-MATTILA, Kaisa. Usability Meets Sociology for Richer Consumer Studies. In: Lindholm, C.; Keinonen, T.; Kiljander H., Mobile Usability: How Nokia Changed the Face of the Mobile Phone, McGraw-Hill, 2003. 304 p.

NORMAN, Donald A. The Design of Everyday Things. New York: Doubleday/Currency, 1990.

O'BRIEN, Jon; RODDEN, Tom; ROUNCEFIELD, Mark; HUGHES, John. At Home with the Technology: An Ethnographic Study of a Set-TopBox Trial. ACM Transactions on Computer-Human Interaction, Vol. 6, No. 3, 1999. 282-308 p.

QUICO, Célia; DAMÁSIO, Manuel J. Televisão Digital e Interactiva: a modelação social como variável na avaliação de usabilidade. In Oficina TV Interativa IHC 2004, 2004, Curitiba, Brasil. 
RASKIN, Jef. The humane interface: new directions for designing interactive systems. ACM Press, 2000. 233 p.

ROSENFELD, Louis; MORVILLE, Peter. Information Architecture for the World Wide Web. O'Reilly, Sebastopol, CA, 2002. 461 p.

SHNEIDERMAN, Ben. Designing The User Interface: Strategies for effective human-computer interaction. Addison Wesley, 1998.

SILVER, Janet; GILL, John; SHARVILLE, Christopher; SLATER, James. A new font for digital Television subtitles. , 2000. Disponível em:

$<$ http: / / www.tiresias.org/fonts / design_report_sf.htm>. Acesso em: 07 Jul 2005.

SMITH, D. C.; IRBY, C.; KIMBALL, R.; VERPLANK, W. Designing the Star User Interface. Guidebookgallery.org, 1982. Disponível em: $<$ http: / / www.guidebookgallery.org/articles/designingthestaruserin terface>. Acesso em: 25 Jun 2006.

SPINELLIS, Diomidis D. The Information Furnace: Consolidated Home Control. Personal Ubiquit. Comput. No. 7, Londres: Springer-Verlag, 2003. 53-69 p.

SRIVASTAVA, H. O. Interactive TV Technology \& Markets. Artech House Publishers, 2002. 448 p.

TAYLOR, Alex; HARPER, Richard. Switching on to switch off: A Analysis of Routine TV Watching Habits and Their Implications for Electronic Programme Guide Design. R. Harper (Ed.), Inside the Smart Home, Londres: Springer-Verlag, 2003. 115-126 p.

THOMASSON, Michael. Winky Dink, the History of Interactive Television, and You. Gooddealgames.com, 2003. Disponível em: <http: / / www.gooddealgames.com/articles/Winky_Dink.html>. Acesso em: 05 Jan 2006.

TIRESIAS. Guidelines: Television. Tiresias, 2006. Disponível em: $<$ http: / / www.tiresias.org/guidelines/television.htm>. Acesso em: 29 Jul 2006.

WHITAKER, Jerry. DTV: The Revolution in Digital Video. McGraw-Hill Professional, 2001. 